FLORINDA FIGUEIREDO BORGES

INTERVENÇÃO ESTATAL NA ECONOMIA: O BANCO CENTRAL E A EXECUÇÃO DAS POLÍTICAS MONETÁRIA E CREDITÍCIA

\author{
DisSertaÇão DE MeSTRAdo
}

Orientador: Professor Doutor José Tadeu De ChiARa

FACULDADE DE DIREITO DA USP

SÃO PAULO

2010 


\title{
INTERVENÇÃO ESTATAL NA ECONOMIA: O BANCO CENTRAL E A EXECUÇÃO DAS POLÍTICAS MONETÁRIA E CREDITÍCIA
}

\author{
Dissertação de Mestrado apresentada à Banca \\ Examinadora da Faculdade de Direito da Universidade de \\ São Paulo, como exigência parcial para a obtenção do \\ título de Mestre em Direito, sob orientação do Prof. Dr. \\ José Tadeu De Chiara
}

FACULDADE DE DIREITO DA USP

SÃO PAULO

2010 
Banca Examinadora 
Dedico este trabalho a meus pais Vera e Carlon. 


\section{AGRADECIMENTOS}

Agradeço ao Professor Doutor José Tadeu De Chiara que me orientou desde os primeiros anos de graduação na Faculdade de Direito do Largo de São Francisco até a árdua, porém gratificante, pós-graduação. Foram preciosas as lições de Direito e, especialmente, as lições de vida aprendidas nesse período.

Agradeço aos meus amados pais Carlon e Vera, pessoas maravilhosas e extremamente dedicadas a tudo o que fazem, verdadeiras fontes de inspiração. Também sou grata às minhas irmãs, Violeta e Bárbara, amigas para toda a vida, pelo apoio que não me deixaram faltar.

Contribuiu decisivamente para a elaboração deste trabalho Otavio Yazbek, amigo querido e professor dedicado de todas as horas, a quem aqui registro meus sinceros agradecimentos.

Devo agradecer ainda aos amigos Andrés Klenner e Ana Paula Corazzari a preciosa troca de experiências a respeito do tema e sobre tópicos da bibliografia.

A todos aqueles que, em algum momento, torceram pelo sucesso deste projeto.

Por fim, agradeço ao meu amor, Thiago Ladeira, que acompanhou com paciência e dedicação todas as fases de elaboração deste trabalho. Sem ele, nada teria a mesma graça. 


\section{RESUMO}

Este trabalho presta-se a analisar a adequação da execução da política monetária pelos Bancos Centrais, com enfoque especial dado ao Banco Central do Brasil e ao arcabouço normativo atualmente em vigor sobre a matéria. A necessidade de desenvolver este tema sobreveio da verificação, especialmente nas duas últimas décadas, de um distanciamento dos Bancos Centrais em relação às orientações do Poder Executivo. $\mathrm{O}$ regime de metas inflacionárias, tido como o ideal para orientar a atuação dos Bancos Centrais e assegurar a estabilidade da moeda foi assumido como o objetivo-fim da política monetária, em detrimento das previsões constitucionais acerca da promoção do desenvolvimento equilibrado do País, da busca do pleno emprego e da redução das desigualdades sociais. Para a análise desenvolvida, partiu-se do método histórico, por meio do qual foi possível verificar, a partir do Século XIX até o presente, de que forma os Bancos Centrais surgiram e galgaram posições de relevo enquanto agentes do Estado orientados a intervir na economia para fins de promoção social, especialmente a partir do surgimento e consolidação do Direito Econômico como ciência jurídica legitimadora da intervenção estatal. Em seguida, buscou-se explorar as funções dos Bancos Centrais, os instrumentos dos quais dispõem para o exercício da política monetária e a adequação dos objetivos dessa política no contexto da política econômica desenvolvida pelo Estado. Por fim, passou-se à análise do Banco Central do Brasil no que concerne a evolução da execução da política monetária, paralelamente às conquistas sociais e políticas do país, com especial destaque para as décadas de 1960 e 1990.

Palavras-chave: Autonomia do Banco Central, Banco Central do Brasil, Consenso de Washington, Direito Econômico, Independência dos Bancos Centrais, Intervenção Estatal, Metas de Inflação, Padrão-Ouro, Política Econômica, Política Monetária. 


\section{ABSTRACT}

This work is to examine the appropriateness of implementing monetary policy by central banks, with particular emphasis given to the Central Bank of Brazil and the regulatory framework currently in force on the matter. The need to develop this theme came to check, especially in the last two decades, from a distance of central banks in relation to Executive guidelines. Inflation targeting system, seen as the ideal to drive central banks' actions and ensure currency stability was adopted as the end goal of monetary policy at the expense of constitutional statements upon balanced development of the country, in pursuit of comprehensive employment and the reduction of social inequalities.

For the developed analysis, historical method has been adopted which enabled the understanding from the nineteenth century until present days upon how Central Banks emerged and have risen to prominent positions as agents of the Stated driven to intervene in economy for social advancement, especially since the emergence and consolidation of Economic Law and legal science legitimating state intervention. Then Central Banks central banks functions were explored, theirs tools for monetary policy undertaking and the adequacy of such objectives in the context of economic policy developed by the state. Finally, we have assessed Brazil Central Bank in regards of monetary policy implementation development, along with social and political local achievements, with particular emphasis to the 60's and 90's.

Keywords: Autonomy of Central Banks, Central Bank, Economic Law, Economic Policy, Independence of Central Banks, Inflation Targeting, Gold Standard, Monetary Policy, Washington Consensus. 


\section{SUMÁRIO}

INTRODUÇÃO 9

CAPÍTULO I. O ESTADO E O MERCADO. UMA RELAÇÃO TUMULTUADA............ 10

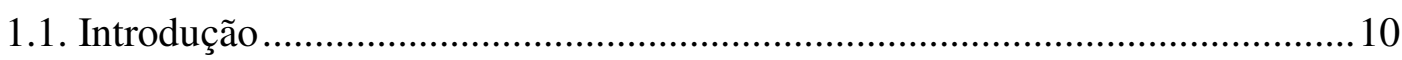

1.2. O século XIX - Surgimento e Consolidação do Estado Liberal e da

Economia de Mercado ............................................................................. 12

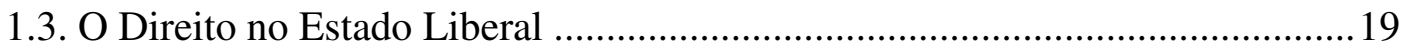

1.4. A sustentação do Padrão-Ouro entre os Séculos XIX e XX ............................22

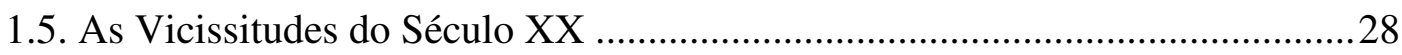

1.6. A origem liberal e consolidação intervencionista dos Bancos Centrais ............36

1.7. O Direito no Estado Intervencionista ..........................................................42

1.8. Bretton Woods e o Estado-Providência ..........................................................46

1.9. O Colapso da Sistemática de Bretton Woods .................................................51

1.10. O consenso de Washington e o Estado Neoliberal .........................................54

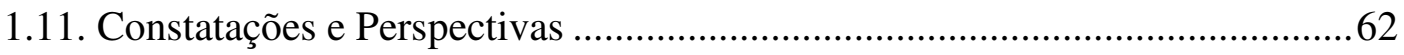

\section{CAPÍTULO II. EXECUÇÃO DAS POLÍTICAS MONETÁRIA E CREDITÍCIA. O} PAPEL DOS BANCOS CENTRAIS ................................................6 64

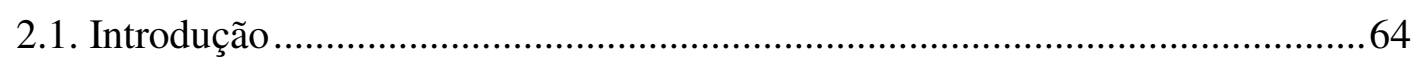

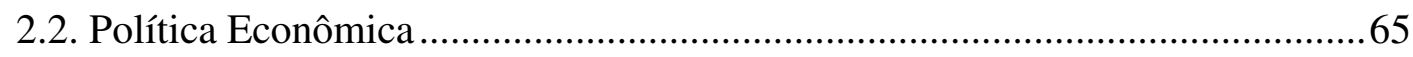

2.3. Política Monetária: Conceito e Objeto .............................................................67

2.4. Instrumentos para o exercício da Política Monetária ...................................... 73

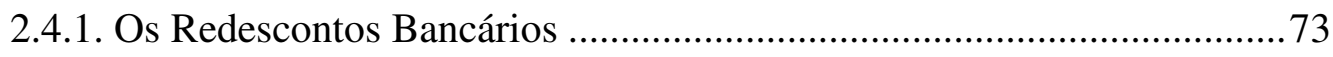

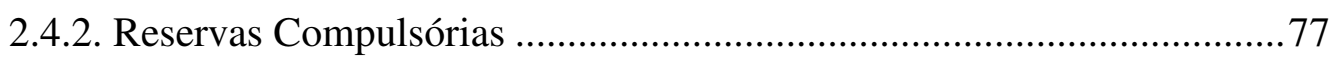

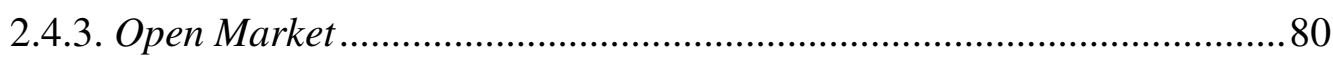

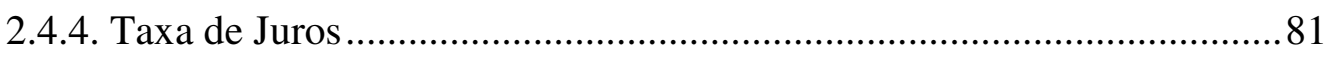

2.5. Os Bancos Centrais e a Política Monetária - A visão doutrinária.................... 83

2.5.1. Estabilidade de Preços como objeto da Política monetária ....................86

2.5.2. A questão da Autonomia dos Bancos Centrais......................................89

2.6. Os Bancos Centrais e a Política Monetária - Análise de Casos ..................... 100

2.6.1. Federal Reserve System (FED) ....................................................... 101 
2.6.2. Banco Central Europeu 104

2.6.3. Bancos Centrais da América Latina 110

2.6.3.1. Banco Central do Chile 111

2.6.3.2. Banco Central da Venezuela ..................................................... 114

2.6.3.3. Banco Central da Argentina .................................................... 120

2.6.3.4. Considerações Gerais sobre os Bancos Centrais da América Latina 125

2.7. Constatações e Perspectivas 127

\section{CAPÍTULO III. O ESTADO BRASILEIRO. O BANCO CENTRAL DO BRASIL E} A POLÍTICA MONETÁRIA 129

3.1. Introdução 129

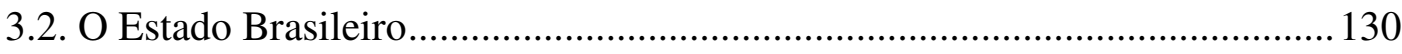

3.2.1. As Conformações Históricas do Estado Brasileiro .............................. 131

3.2.2. Década de 1930 e o Processo de Industrialização ................................. 140

3.2.3. O Estado Brasileiro entre 1930 e 1980 ................................................. 144

3.2.4. A Década de 1990 e o Plano Real ............................................................. 151

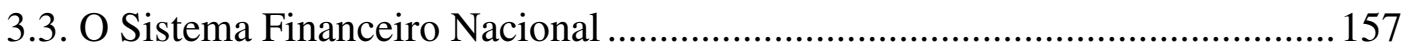

3.3.1. O Banco do Brasil .............................................................................. 158

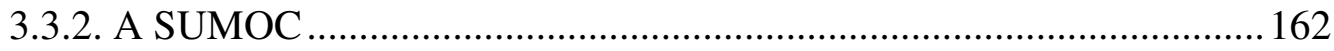

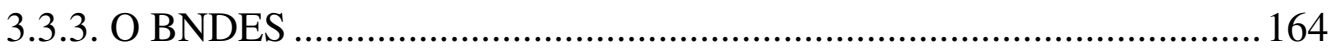

3.4. A reforma do Sistema Financeiro e a instituição do Banco Central do Brasil

3.4.1. O Banco Central e o Tesouro Nacional

3.4.2. O Papel das Instituições Financeiras na Execução da Política

Monetária 173

3.4.3. O Banco Central do Brasil e o CMN - A questão da Autonomia

3.5. A Política Monetária Brasileira e o Regime de Metas para a Inflação 183

CONCLUSÃO 192 


\section{INTRODUÇÃO}

Neste trabalho, dividido em três capítulos, pretende-se analisar as políticas monetária e creditícia executada pelos Bancos Centrais de acordo com a política econômica formulada pelo Estado.

O primeiro capítulo tratará das origens e da evolução do capitalismo, tomando-se o período compreendido entre o Século XIX e os dias correntes. Nele serão analisados os comportamentos e decisões do passado que refletem a ordem econômica e interferem diretamente na realidade sociopolítica atual. Trata-se, portanto, do substrato necessário para contextualizar a consolidação do Banco Central como órgão estatal responsável pela execução das políticas monetária e creditícia.

O segundo capítulo tratará especificamente do Banco Central, o qual, por ser parte integrante do Estado, tem como dever principal executar a política monetária orientada para contribuir para o desenvolvimento da sociedade. Este capítulo versará sobre o legítimo papel dessa instituição, as ferramentas de que se utiliza para a execução da política monetária e de crédito, bem como sobre a sua autonomia em relação ao Estado.

No terceiro e último capítulo estará em foco o Banco Central do Brasil. Empreendese um estudo sobre essa instituição com base no contexto da formação e evolução do Estado brasileiro e das instituições componentes do Sistema Financeiro Nacional, utilizando-se como fio condutor para essa análise a administração das políticas monetária e creditícia à luz do ordenamento jurídico nacional.

Pretende-se, ao longo dos capítulos deste trabalho, evidenciar a importância da existência dos bancos centrais e a condução das políticas monetárias administradas por eles em toda e qualquer ordem social. 


\title{
CAPÍTULO I. O ESTADO E O MERCADO. UMA RELAÇÃo TUMULTUADA
}

\begin{abstract}
"La historia es en sí misma un instrumento crítico de primer orden y recordando las opiniones emitidas en otro tiempo por grandes inteligencias, los errores que han cometido, las circunstancias en que tales opiniones surgieron, se ayuda a mostrar en su verdadero aspecto muchas teorías producidas hoy y que sus autores creen de muy buena fe enteramente nuevas. Bueno es recordar que la historia se repite, pero es preciso añadir que no se repite nunca exactamente del mismo modo. Son precisamente las variantes las que constituyen toda la dificultad de los problemas sometidos a la inteligencia y valentía de los gobiernos de hoy". RIST, Charles. Historia de las Doctrinas relativas al Crédito y a La Moneda - desde Jonh Law hasta La actualidad. ${ }^{1}$
\end{abstract}

\subsection{Introdução}

Este primeiro capítulo versará sobre a relação tumultuada entre Estado e o mercado $^{2}$, do século XIX até os dias correntes. Saciar os anseios capitalistas e garantir, ao mesmo tempo, a preservação das funções essenciais do Estado tem sido um desafio recorrente para a sociedade moderna. De um lado, a incessante busca por maximização de eficiência, redução de custos, aumento de produção e lucros; de outro, a missão de assegurar à sociedade as condições necessárias ao seu desenvolvimento equilibrado, uniforme e permanente.

A história do capitalismo construiu-se com base na busca pela conciliação entre os fins do Estado $^{3}$ e a evolução do mercado. Adotando o método histórico, pretende-se traçar uma linha do tempo, com a exposição sobre a evolução dos mercados em paralelo à

\footnotetext{
${ }^{1}$ Tradução de Ernesto Schop Santos. Barcelona: Bosch Casa Editorial, 1945. p. 17.

${ }^{2}$ Para os fins deste trabalho, "mercado" deverá ser compreendido, na grande maioria das vezes em que o termo for mencionado, com o propósito de referir às relações sociais desenvolvidas de acordo com o modo de produção capitalista, ou, como pontua BERCOVICI, Gilberto. “(...) o mercado é uma estrutura social, fruto da história e de decisões políticas e jurídicas que servem a determinados interesses, em detrimento de outros", na obra: BERCOVICI, Gilberto. O ainda indispensável direito econômico. In: BENEVIDES, Maria Victoria de Mesquita; BERCOVICI, Gilberto; MELO, Claudineu. (Orgs.) Direitos humanos, democracia e República: homenagem a Fábio Konder Comparato. São Paulo: Quartier Latin, 2009. p. 504.

3، O mais acertado critério metodológico, a nosso ver, para se chegar à consideração do problema [quais são os fins do Estado] seria situá-lo historicamente, e daí submetê-lo a reflexões da filosofia, da história, da política e do direito, ou seja, tratá-lo no plano metafísico ou positivo que abranger, segundo as idéias dominantes da época. Teríamos assim, por único ponto de partida, o histórico, que, uma vez admitido, permitiria o subseqüente exame da matéria debaixo de todos os ângulos possíveis de indagação." BONAVIDES, Paulo. Teoria do Estado. 7. ed. São Paulo: Malheiros, 2009. p. 111.
} 
intervenção do Estado na economia, dado o objeto do direito econômico no qual este trabalho se apoia. Trata-se, portanto, do substrato necessário para que seja possível contextualizar o surgimento do Banco Central como órgão estatal responsável pela execução da política monetária e creditícia e, assim, desvendar os limites de sua atuação.

Articulando as transformações evolutivas do mercado com as etapas de expansão do modo de produção capitalista entre os séculos XIX e XX, este capítulo terá o condão de retratar os comportamentos e decisões do passado que refletem a ordem econômica e impactam diretamente a realidade sociopolítica atual.

Com propósito de proporcionar a reflexão sobre alguns dos aspectos determinantes para a compreensão de importantes questões da política econômica, serão investigadas como os motivos pelos quais as teorias liberais, que propunham um mercado autorregulável, embora tenham trazido nefastas consequências à civilização da Europa Ocidental no século XIX, ironicamente, foram retomadas com força total a partir da década de 1970. Ou, mesmo, resgatando os momentos áureos do Padrão-Ouro, será possível refletir sobre a origem da dificuldade enfrentada por boa parte dos estados nacionais no estabelecimento de uma política monetária eficiente. $\mathrm{Ou}$, ainda, refletir sobre o desmonte da política do Estado-Providência por meio da adesão aos ditames do Estado Neoliberal e suas consequências.

Para tanto, inicialmente, serão estudadas as principais características da ideologia liberal adotadas predominantemente na Europa Ocidental do século XIX, no contexto do movimento que levou ao ideal de mercado "autorregulável". Embora muito do que será discutido no presente trabalho tenha raízes em épocas anteriores, para extrair as implicações mais relevantes que circundam o tema-chave deste estudo, optou-se pelo século XIX que corresponde ao florescimento do capitalismo ${ }^{4}$.

Posteriormente, já no século XX, será analisada a revisão da proposta liberal, sob a influência determinante do pensamento keynesiano. Além disso, a revisão dos paradigmas do mercado autorregulável o nascimento da concepção de Estado Intervencionista

\footnotetext{
${ }^{4}$ Este ponto de partida foi escolhido justamente por ilustrar a transição do Estado absolutista para o Estado mínimo. A grande cisão nos sistemas de ordem ocorreu no final do séc. XVIII. Tratou-se essencialmente de uma mudança de referencial: a grande novidade no padrão de ordem reconhecida até então foi a superação do critério estamental. Até então, as respostas a questões como "quem pode ser proprietário?", "quem pode contratar?", eram baseadas na posição social ocupada pelo indivíduo: patrícios, clero, suseranos, monarcas, nobres. Sempre o estamento justificava a ordem. A grande novidade a partir do séc. XIX é a superação desse critério - surge uma sociedade organizada de forma desvinculada dos estamentos, na qual a disponibilidade monetária passou a ter significância em termos de quem poderia ser proprietário e quem poderia contratar.
} 
inspirado no Welfare State como estimulador da economia e promotor do bem-estar social, bem como a consolidação dos Bancos Centrais como órgãos públicos responsáveis pela política monetária e creditícia.

Em seguida, será examinada a dinâmica entre o mercado e o Estado Intervencionista - que predominou desde 1950 até meados da década de 1970 - com enfoque nas crises econômicas desencadeadas a partir desse período, as quais provocaram severas críticas ao conceito de Estado Keynesiano, por ser considerado excessivamente oneroso e "agigantado". Esse movimento culminou com a formulação das diretrizes do “Consenso de Washington”, em 1989.

Por fim, será objeto de reflexão a concepção do chamado "Estado Neoliberal”, com base nas premissas que nortearam o referido Consenso de Washington e seus impactos econômicos e sociais, especialmente no que tange aos direitos individuais dos cidadãos e à tentativa de enfraquecer a soberania dos Estados Nacionais ${ }^{5}$.

\subsection{O século XIX - Surgimento e Consolidação do Estado Liberal e da Economia de Mercado}

De acordo com Weber $^{6}$, o primeiro vestígio de uma política econômica racional encontra-se na Inglaterra do século XIV, sob a denominação de mercantilismo que o próprio Weber define como a fase em que houve a transferência do lucro capitalista para a política. A

\footnotetext{
${ }^{5}$ [No século XVIII] o Estado Moderno já apresentava traços inconfundíveis de sua aparição cristalizada naquele conceito sumo e unificador - o de soberania, que ainda hoje é seu traço mais característico, sem embargo das relutâncias globalizadoras e neoliberais convergentes no sentido de expurgá-lo das teorias contemporâneas de poder. A base justificativa dessa pretensão aniquiladora daquele conceito consiste em apontar uma realidade distinta, imposta por novos modelos associativos de mútua interdependência estatal, os quais, para ganharem eficácia prevalência na conjuntura globalizadora, buscam a todo transe remover e apagar e amortecer o conceito de soberania. E tais diligências destrutivas da autodeterminação das Nações se fazem com muito empenho, porque a soberania nacional é óbi7ce à soberania dos mercados. De titularidade internacionalizada e invisível, esta nova e dissimulada soberania dos mercados executa o projeto recolonizador das gigantescas associações de capital, que ignoram por completo os direitos dos povos e das Nações periféricas a romper as cadeias do subdesenvolvimento e espancar as trevas da noite em que a globalização os mergulhou. BONAVIDES, Paulo. op. cit., p. 33.

${ }^{6}$ A prática mercantilista, que vigorou entre os séculos XIV e XVIII, tinha o foco voltado para o comércio com o objetivo de acumular metais preciosos e já indicava a transformação social presenciada pelo capitalismo. Nessa etapa, desenvolviam-se os primeiros centros urbanos: "Mercantilismo significa a transferência do interesse de lucro capitalista para a política. O Estado procede como se estivesse única e exclusivamente integrado por empresários capitalistas. A política econômica para o exterior apóia-se no princípio de comprar o mais barato possível e vender o mais caro que se possa. A finalidade mais elevada consiste em fortalecer o poderio do Estado até o exterior. O mercantilismo implica, portanto, potências constituídas na forma moderna, isto é, diretamente pelo incremento do erário público, e inteiramente através da capacidade tributária da população.”, WEBER, Max. Os pensadores. 3.ed. São Paulo: Abril, 1985. p. 163.
} 
idéia era propiciar o exponencial enriquecimento população por meio da exploração da atividade comercial, comprando-se sempre mais barato e vendendo-se mais caro de modo que, na qualidade de contribuinte, a população pudesse transferir parte dessa riqueza ao Estado.

Fábio Konder Comparato relata o caso do Banco Médici de Florença que, no século $\mathrm{XV}$, constituiu o primeiro caso histórico de grupo societário de que se tem notícia, organizado sob uma estrutura de holding ${ }^{7}$, cujas controladas estavam espalhadas por diversas regiões. Esse caso ilustra o quão remotas são as origens da organização produtiva de mercado e, presta-se a quebrar o paradigma de que os sistemas econômicos, antes da consolidação do modo de produção capitalista, foram organizados para atender as necessidades primárias do indivíduo, tais como comer e vestir-se, utilizando essencialmente para esses fins o escambo de mercadorias.

Muito antes disso $^{8}$, a acumulação de riquezas já representava o objetivo-fim norteador da atividade produtiva. Todavia, com as transformações emersas durante o século XIX, a atividade econômica voltada para o lucro passou a fazer parte do cotidiano do homem médio, inaugurando-se, assim, a era do capital.

Na verdade, em meados do século XIV, o processo de acumulação do excedente foi um dos fatores que determinou o declínio do sistema feudal. Os camponeses que cultivavam terras arrendadas dos senhores feudais perceberam que poderiam trocar por dinheiro os excedentes de sua produção e, com esse dinheiro, substituir as prestações de trabalho que deviam ao senhor (comutações). Conforme destacam Hunt e Sherman?

Este sistema proporcionou aos camponeses um estímulo maior para produzirem, ampliando o excedente comercializável, o que os levava a obter novas comutações que por sua vez redundavam em mais excedentes e renda monetária, e assim por diante. $\mathrm{O}$ efeito cumulativo deste processo solapou, pouco a pouco, os vínculos tradicionais do feudo, instaurando, em seu lugar, as relações de mercado e a busca de lucros como princípios organizadores da produção. Em meados do século XIV, em muitas partes da Europa, as rendas em dinheiro excediam o valor das prestações de trabalho.

\footnotetext{
${ }^{7}$ COMPARATO, Fábio Konder. Na proto-historia das empresas multinacionais - o Banco Medici de Florença. Revista de Direito Mercantil, Industrial, Econômico e Financeiro, São Paulo, v. 54, p. 108 e ss., 1984 "Como se vê, o fenômeno da participação de uma sociedade em outra, que a jurisprudência européia só veio a admitir, a duras penas, no final do século passado, era normalmente praticado pelos banqueiros florentinos quatro séculos antes. (...)Tanto as filiais no estrangeiro, quanto os três estabelecimentos industriais em Florença, organizavam-se sob a forma societária, tendo razão social, capital e livros próprios. (...) É fascinante verificar como esse exemplar avoengo das empresas multinacionais de hoje encerra, em sua original organização, todos os característicos e problemas dos grupos atuais".

${ }^{8}$ Comparato, em Na proto-historia das empresas multinacionais - o Banco Medici de Florença, cit., comenta a falência dos Bardi em 1345 como a mais espetacular da Idade Média.

${ }^{9}$ HUNT, E. K.; SHERMAN, Howard J. História do pensamento econômico. Tradução de Jaime Larry Benchimol. 2. ed. Rio de Janeiro: Vozes, 1978. p. 30.
} 
Portanto, a busca pelo lucro e pela acumulação remonta os tempos feudais, tendo sido, em verdade, uma das causas de seu declínio ${ }^{10}$.

Entretanto, De acordo com Karl Polanyi, na obra "A Grande Transformação", menciona a tendência de os defensores do pensamento liberal entenderem a organização econômica da sociedade pré-Riqueza das Nações, de Adam Smith, como insignificante do ponto de vista econômico, inclusive pelo fato de não dar lugar proeminete ao lucro.

Entendimento um tanto ingênuo dado que das sociedades mais antigas ${ }^{11}$ advém a mais importante das constatações: o homem é, bem como sempre foi, um ser social. A economia do homem, como regra, está submersa em suas relações sociais. Suas ações, seus objetivos direcionam-se para encontrar meios para salvaguardar seu status, a posição que ocupa na sociedade, seu patrimônio social. Essa compreensão fundamental trazida dos estudos da história das civilizações serve como ponto de partida para todas as teorias econômicas que se desenvolveram depois. Aliás, seria impossível pensar sobre teoria econômica sem tomar como pressuposto as relações sociais.

Com base no raciocínio sobre o "ser social", é possível verificar a transformação pela qual passou a sociedade a partir do século XIX. O status do homem, antes ligado essencialmente à propriedade de terras e a acumulação de metais preciosos em que o comércio era fortemente regulado ${ }^{12}$, passou a estar diretamente relacionado com o lucro

\footnotetext{
10،“(..) os sistemas econômicos conhecidos por nós até o fim do feudalismo na Europa Ocidental foram organizados segundo os princípios da reciprocidade, da redistribuição ou domesticidade, ou alguma combinação dos três. Esses princípios eram institucionalizados com a ajuda de uma organização social a qual, inter alia, fez uso dos padrões de simetria, centralidade e autarquia. Dentro dessa estrutura, a produção ordenada e a distribuição dos bens era assegurada através de uma grande variedade de motivações individuais, disciplinadas por princípios gerais de comportamento. E entre essas motivações, o lucro não ocupava lugar proeminente". POLANYI, Karl. A grande transformação: as origens de nossa época. Tradução de Fanny Wrobel. Rio de Janeiro: Campus, 2000. p. 75.

${ }^{11}$ Aristóteles, o maior filósofo da Antiguidade, no Século III antes de Cristo deixou importante lição antropológica sobre a natureza social do homem. O homem é um animal social e político por natureza. E, se o homem é um animal político, significa que tem necessidade natural de conviver em sociedade, de promover o bem comum e a felicidade. A pólis grega encarnada na figura do Estado que representa a sociedade 0é uma necessidade humana. "Evidentemente o Estado está na ordem da natureza e antes do indivíduo; porque, se cada indivíduo isolado não se basta a si mesmo, assim também se dará com as partes em relação ao todo. Ora, aquele que não pode viver em sociedade, ou que nada precisa por bastar-se a si próprio, não faz parte do Estado; é um bruto ou um deus. A natureza compele, assim, todos os homens a se associarem." ARISTÓTELES. $A$ política. Trad. Nestor Silveira Chaves, 15. ed. São Paulo: Ed. Escala, 1995. p. 14.

${ }^{12}$ Sobre a deterioração das práticas mercantilistas que culminaram na revolução capitalista e no regime de mercado autorregulável, HUBERMAN, Leo. História da riqueza do homem. Tradução de Waltensir Dutra. 21. ed. Rio de Janeiro: LTC, 1986. p. 137 destaca: "Podia o fabricante de tecidos, por exemplo, fabricar o tipo de fazenda que lhe agradasse? Não. Os tecidos tinham que ser de uma qualidade determinada, e nada mais. Podia o fabricante de chapéu atrair a procura do consumidor produzindo chapéus feitos de uma mistura de castor, pele e lã? Não. Só podia fazer chapéus todos de castor ou todos de lã, e nada mais. Podia o fabricante usar uma ferramenta nova e talvez melhor na produção de suas mercadorias? Não. As ferramentas tinham que ser de determinado tamanho e forma, e os inspetores apareciam sempre para
} 
obtido com as relações produtivas desenvolvidas no mercado. O lugar do indivíduo na sociedade passou, em larga medida, a ser definido de acordo com o tipo de atividade produtiva à qual estava ligado e ao quanto poderia acumular por meio do desenvolvimento de tal atividade, passando a dinâmica de mercado a conformar o conjunto das relações sociais ${ }^{13}$.

Com efeito, a ideia do mercado como espaço da liberdade evolui mais fortemente no final do século XVIII e durante todo o século XIX, quando se consolida o livre comércio e o livre movimento de capitais entre os vários tipos de atividade produtiva e entre as várias regiões. Nesse cenário, são erigidos os pilares do pensamento liberal clássico $^{14}$ que incorporam as crenças econômicas dos interesses dominantes segundo as quais os mercados, se forem deixados em livre funcionamento, tendem a ajustar-se automaticamente.

Para os liberais inspirados por Adam Smith o postulado mais importante era eliminar todas as barreiras ao intercâmbio. Com isso as economias das nações tenderiam a especializar-se nas produções em que fossem mais eficientes e, nesse sentido, deveriam negociar seus produtos com outras economias para adquirir outras mercadorias das quais necessitassem e que não fossem capazes de produzir de forma tão eficiente.

verificar isso. O resultado natural desse avanço excessivo numa direção seria um movimento igualmente profundo na outra. O controle demasiado da indústria estimulou a luta pela ausência total de controle."

${ }^{13}$ Com efeito, o próprio mercado é produto das interações sociais, tal como destaca YAZBEK, Otavio. Regulação do mercado financeiro e de capitais. São Paulo: Campus, 2007. p. 61. Os mercados estão, na realidade, imersos no conjunto de relações sociais, sobre eles incidindo um amplo leque de regras, procedimentos e padrões, formais ou informais. Assim, a dinâmica e a conformação dos mercados não resultam apenas de decisões racionais dos agentes, mas também de processos históricos e culturais e de determinadas decisões políticas fundadoras - não se trata assim de um fenômeno endógeno, restrito às atividades econômicas.

${ }^{14}$ Conforme demonstra HUGON, Paul. Economistas célebres. Textos selecionados e apresentados pelo autor. São Paulo: Atlas, 1955. p. 133-212, mesmo com todas as ressalvas em relação à obsolescência das ideias de Smith, não há como negar que as bases da teoria liberal, as quais dominaram as mentes mais influentes do século XIX, foram ditadas por ele - o fundador da economia política como campo específico de investigação. Teve como principais seguidores e propagadores de sua teoria Robert Malthus, David Ricardo e Stuart-Mill na Inglaterra e Jean Baptiste Say na França. Os pilares do pensamento liberal foram lançados em 1776, na obra clássica A riqueza das nações: investigação sobre sua natureza e suas causas. Tradução de Luiz João Baraúna. São Paulo: Nova Cultural, 1996, por meio da qual o autor defendeu que a eficiência no desenvolvimento das atividades produtivas reside na adequada divisão do trabalho e que os interesses individuais levam inevitavelmente ao bem social comum, por meio da mão invisível - metáfora que utilizaria para explicar como as forças automáticas do livre mercado são capazes de conferir equilíbrio econômico à sociedade. Cumpre destacar que os argumentos lançados por Smith estão marcados por sua oposição ao mercantilismo que alcançou seu auge no século XIII, no qual o comércio e a acumulação de metais seria a forma defendida para o alcance do desenvolvimento industrial, em contraposição ao que defendia Smith: que a riqueza das nações somente poderia ser aumentada com o foco na produção, no trabalho humano e na utilização do lucro acumulado para o desenvolvimento e aprofundamento de melhores técnicas de divisão do trabalho. 
Segundo o pensamento liberal, prevalecia a ideia de que o limite da eficiência na divisão do trabalho corresponde ao limite da extensão dos mercados. Quanto mais livres e abertos, melhor seria ${ }^{15}$. Ao Estado caberia controlar o cumprimento dos contratos e garantir estabilidade para o desenvolvimento das relações privadas, vale dizer, seu exclusivo dever seria o de conferir segurança aos negócios jurídicos, sem, contudo, controlar ou mesmo interferir no seu funcionamento.

Essas premissas fundavam-se na interpretação de que o mercado tenderia - sozinho - a corrigir a alocação de recursos e a conduzir a economia a um equilíbrio de pleno emprego de fatores e, consequentemente, ao contínuo desenvolvimento.

Ao preferir fomentar a atividade do país e não de outros países ele [o indivíduo] tem em vista apenas a própria segurança; e, orientando sua atividade de tal maneira que sua produção possa ser de maior valor, visa apenas a seu próprio ganho e neste, como em muitos outros casos, é levado como que por mão invisível a promover um objetivo que não fazia parte de suas intenções. Aliás, nem sempre é pior para a sociedade que esse objetivo não faça parte das intenções do indivíduo. Ao perseguir seus próprios interesses, o indivíduo muitas vezes promove o interesse da sociedade muito mais eficazmente do que quando tenciona realmente promovê-lo. Nunca ouvi dizer que tenham realizado grandes coisas para o país aqueles que simulam exercer o comércio visando ao bem público. ${ }^{16}$

A ideia central de toda a teoria liberal, que defende o afastamento do Estado da vida econômica, fundamenta-se no entendimento de que o modo de produção capitalista seria naturalmente multiplicador de renda e gerador de empregos ${ }^{17}$. Isso se explicaria pelo fato

15،O que é prudente na conduta de qualquer família particular dificilmente constituirá insensatez na conduta de um grande reino. Se um país estrangeiro estiver em condições de nos oferecer uma mercadoria a preço mais baixo do que uma mercadoria fabricada por nós mesmos, é melhor comprá-la com uma parcela da produção de nossa própria atividade, empregada de forma que possamos auferir alguma vantagem. A atividade geral de um país, por ser sempre proporcional ao capital que lhe dá emprego, não diminuirá com isso, da mesma forma como não diminui a atividade dos profissionais acima mencionados; o que resta é descobrir a maneira pela qual ela pode ser aplicada para trazer a maior vantagem possível.” SMITH, Adam. op. cit., p. 439.

${ }^{16}$ Id. Ibid.

${ }^{17}$ Jean Baptiste Say, discípulo francês de Adam Smith e difusor de seus pensamentos fora da Inglaterra, propagou com sua principal obra, Traité D’Economie Politique (1841), a "teoria das saídas", cujo fundamento básico seria o de que os produtos se trocam com os produtos, ou seja, a moeda seria apenas um instrumento destinado a intermediar essa troca, destituída de qualquer função no estabelecimento do equilíbrio econômico e na formação de preços. Quanto mais produção houvesse, mais saídas haveria de tais produtos e mais seria necessário produzir para trocar por outros. Assim, os empregos automaticamente se multiplicariam em razão da constante demanda de mão de obra oriunda desse incessante incremento do processo de produção: "De qualquer modo a compra de um produto só pode ser efetuada com o valor de outro. A primeira consequiência que se pode tirar desta importante verdade é a seguinte: em todas as nações, quanto mais numerosos forem os produtores e múltiplas as produções, tanto mais fáceis e variadas serão as saídas. (...) Para fomentar a indústria, não basta apenas o consumo puro e simples; é preciso favorecer o aprimoramento dos gostos e das necessidades, que fazem nascer entre as populações o desejo de consumir. Assim também, para favorecer a venda, é necessário auxiliar os consumidores a ganhar de modo a ficarem em condições de poderem comprar". SAY, J.B. apud HUGON, Paul. op. cit., p. 209 e 212. 
de haver equilíbrio natural na economia o qual não permite que a demanda e oferta de empregos fiquem desequilibradas por um longo período de tempo.

Com base nesse raciocínio, a atuação do Estado em busca da manutenção da ordem econômica seria algo absolutamente dispensável, dado que o mercado possuiria a capacidade ínsita de organizar-se para garantir a estabilidade da economia e o pleno emprego dos cidadãos.

Assim, sem a interferência do Estado, a prosperidade ocorreria naturalmente e haveria não só o funcionamento eficiente do mercado, mas também a adequada distribuição dos bens entre todos. Com base nesses dogmas liberais, ao Estado foi relegado o papel de conferir segurança para o desenvolvimento das relações privadas no âmbito do mercado, ator principal dessa cena econômica.

Nesse sentido, o século $\mathrm{XIX}^{18}$ foi o período em que se verificou a ascensão e auge do liberalismo e da ideia de que o mercado autorregulável e autossuficiente fosse capaz de, sozinho, permitir o crescimento e a estabilidade econômica.

Com o afastamento do Estado, houve uma verdadeira dissociação entre política e economia durante este período. O mercado foi dominado pela metáfora da "mão invisível" e houve a consequente diminuição da atuação dos governos em todos os campos sociais.

Com efeito, o século XIX é significativo por ter presenciado o auge da Revolução Industrial, a consolidação da economia de mercado e por ter preparado o terreno para, no século seguinte, a consagração do modo de produção capitalista.

É significativo, também, por haver transformado o conceito de "trabalho" na história das civilizações. O trabalho do homem, a partir dali, tornou-se a sua principal mercadoria e o seu objetivo ao vender tal mercadoria passou da subsistência, ao lucro.

\footnotetext{
${ }^{18} \mathrm{O}$ mercado autorregulável do século XIX exclui a interferência do Estado na regulação de suas atividades e representa uma ruptura com a política mercantilista do século anterior. Com efeito, verifica-se que a presença do Estado no auge do mercantilismo era bastante forte. Nesse período houve intensa regulação da atividade comercial por parte do Estado. Polanyi chega a afirmar que na Europa Ocidental o Estado criou e organizou os mercados internos da forma como são concebidos nos tempos modernos e, no entanto, esse mesmo Estado foi afastado do controle do mercado no século XIX. "Na política externa, o estabelecimento de um poder soberano era a necessidade do dia; a nova política estatal mercantilista envolvia a disciplina do recurso de todo o território nacional para os objetos de poder nos assuntos externos (...). A intervenção estatal, que havia liberado o comércio dos limites da cidade privilegiada, era agora chamada a lidar com dois perigos estritamente ligados, os quais a cidade havia contornado com sucesso, a saber, o monopólio e a competição. Já se compreendia, naquela época, que a competição levaria, em última instância ao monopólio, (...) O remédio encontrado foi a total regulação da vida econômica , só que agora em escala nacional e não apenas municipal. $\mathrm{O}$ que para a mente moderna pode facilmente parecer com uma imprevidente exclusão da competição, foi, na realidade, um meio de salvaguardar o funcionamento dos mercados, naquelas circunstâncias. POLANYI, Karl. op. cit., 86-87.
} 
Contudo, a despeito de a sistemática de mercado autorregulável idealmente parecer um tipo de negócio livre em que o homem é o dono de sua força de trabalho e, portanto, pode vendê-la a quem bem entender e nas condições que desejar, a verdade é que essa nova compreensão da força produtiva gerou a desarticulação das relações humanas.

A Revolução Industrial distorceu o conceito de liberdade sem regras e sem limites conferida a todos igualmente, fortes e fracos, ricos e pobres, empregadores e empregados. O que se viu no século XIX foi a redução do homem à condição de miséria em detrimento do enorme enriquecimento das nações industriais, em termos absolutos.

Permitir que o mecanismo de mercado seja o único dirigente dos seres humanos e de seu ambiente natural, e até mesmo o árbitro da quantidade e do uso do poder de compra, resultaria no desmoronamento da sociedade. Esta suposta mercadoria, a "força de trabalho", não poderia ser impelida, usada indiscriminadamente ou até mesmo não-utilizada sem afetar também o indivíduo humano que acontece ser o portador dessa mercadoria peculiar (...). Os mercados de trabalho, terra e dinheiro são, sem dúvida, essenciais para uma economia de mercado. Entretanto, nenhuma sociedade suportaria os efeitos de um tal sistema de grosseiras ficções, mesmo por um período de tempo muito curto, a menos que a sua substância humana natural, assim como a sua organização de negócios, fosse protegida contra os assaltos desse moinho satânico ${ }^{19}$.

A busca pelo progresso espontâneo anulou o papel do Estado na vida econômica, papel que deveria ser o de controle de excessos, busca de equilíbrio entre o desenvolvimento da atividade produtiva e a proteção das relações humanas. Impedir esse tipo de intervenção por parte do poder público significou permitir diversos tipos de atrocidades cometidas em nome do "livre mercado".

A civilização do século XIX ruiu ${ }^{20}$ pelo fato de erigir-se sobre um mecanismo institucional que, na verdade, era uma utopia, incapaz de regular o desenvolvimento econômico de uma civilização em todos os seus aspectos.

O liberalismo econômico funcionou nas condições dos séculos XVIII e XIX, numa época em que a tecnologia industrial era relativamente rudimentar e adaptada a empresas de pequena dimensão em que era inexistente ou pouco relevante a concentração capitalista, em que os trabalhadores não estavam organizados (ou dispunham de organizações de classe de existência precária, débeis e inexperientes) e não gozavam da totalidade dos direitos civis e políticos (o que lhes dificultava e reduzia o

\footnotetext{
${ }^{19}$ POLANYI, Karl. op. cit., p. 94.

${ }^{20}$ "Se a queda da nossa civilização foi regulada pelo fracasso da economia mundial, ela certamente não foi causada por ela. Suas origens estão há mais de cem anos atrás, na convulsão social e tecnológica a partir da qual surgiu na Europa a idéia de um mercado auto-regulável. O fim dessa aventura ocorreu em nossa época - ela encerra um estágio na história da civilização industrial.” Id. Ibid., p. 19.
} 
acesso ao aparelho de estado e ao poder político e, conseqüentemente, à obtenção dos direitos econômicos e sociais de que hoje desfrutam); e em que, por isso mesmo, os governos - imunes às exigências e aos votos populares - podiam ignorar impunemente os sacrifícios (e os sacrificados) das crises cíclicas da economia capitalista, qualquer que fosse a sua duração e intensidade. É claro que a 'solução' de impor aos trabalhadores o ônus da 'pagar a crise' só funcionou porque o capitalismo era então, sem disfarces, um sistema em que "os que não podiam trabalhar também não podiam comer" ${ }^{21}$.

Do exposto verifica-se que a proposta do liberalismo contrapõe-se diametralmente às reflexões daqueles que enxergavam no mercado núcleo das distorções e sofrimento da maior parcela da sociedade.

Na prática, os ideais liberais que imperaram absolutos durante o Século XIX não funcionaram como esperado. A mão invisível não foi capaz de evitar a pobreza, o desemprego e as crises econômicas que eclodiram especialmente na primeira metade do século seguinte.

Uma fé cega no progresso espontâneo havia se apossado da mentalidade das pessoas e, com o fanatismo dos sectários, os mais esclarecidos lutavam em favor de uma mudança na sociedade, sem limites nem regulamentações. Os efeitos causados na vida das pessoas foram terríveis, quase indescritíveis. A sociedade humana poderia ter sido aniquilada, de fato, não fosse a ocorrência de alguns contramovimentos protetores que cercearam a ação desse mecanismo autodestrutivo. ${ }^{22}$

Com efeito, o lucro não poderia ser o único fim, a razão máxima e inabalável da existência da sociedade, embora a ordem social se tenha particularizado segundo os interesses dominantes que propugnavam pela liberdade de contratar com o objetivo principal de se obte-lo.

\subsection{O Direito no Estado Liberal}

Após a ruptura com o Ancien Régime, caracterizado pelo absolutismo e pelo direito divino, o advento do Estado Liberal trouxe em seu bojo o império da lei sem a possibilidade da intervenção arbitrária por parte do governante como ocorria no Estado Absolutista. Com a laicização e burocratização do Estado, o direito passa a emanar tão-

\footnotetext{
${ }^{21}$ NUNES, António José Avelãs. Neoliberalismo e direitos humanos. Rio de Janeiro: Renovar, 2003. p. 22.

${ }^{22}$ POLANYI, Karl. op. cit., p. 98.
} 
somente da vontade soberana do legislador político. É a Lei abstrata e geral - todos são iguais perante a lei.

Com o Estado voltado apenas para a gestão da coisa pública e o direito voltado para o particular criam-se as condições favoráveis para a concentração de renda, criação de grandes grupos empresariais e total descaso com o indivíduo sem posses e sem condições de produzir, contratar e lucrar, ficando este, portanto, à margem dessa ordem social.

A conformação jurídica do Estado Liberal foi marcada por dois movimentos de igual importância no que tange a sua caracterização: o movimento constitucionalista e, logo após, o movimento de codificação do direito privado nos países de tradição romanogermânica.

A Revolução Francesa (1789), a Declaração dos Direitos do Homem (1793), a Constituição Francesa (1791) são corolários que dão vida aos princípios que elevam o indivíduo, qualificando - o como sujeito destinatário de direito. Igualdade, liberdade e fraternidade: a busca pela tríade jusfilosófica imperou nessa fase da história; eram os valores a serem elevados e preservados, a conquista do homem em sua individualidade. Os avanços formalizados nas constituições sobre o direito à propriedade, à liberdade de profissão e de contratar, foram alçadas à categoria de direitos fundamentais e inerentes à condição humana.

O princípio da igualdade foi concretizado pela a supressão das diferenças religiosas (estado laico), das diferenças de origem (igualdade formal), e das diferenças locais e territoriais (estado nacional).

Idealmente, essa visão de mundo possui seu encanto; afinal, coloca nas mãos de cada um dos indivíduos o próprio destino. A livre competição, a busca pelo emprego, o livre desenvolvimento das habilidades necessárias para conquistá-lo, enfim, todas as condições para o florescimento dos mercados livres.

Embora se possa discutir se, a rigor, esse Estado Liberal, em sua forma pura, existiu nos vários países europeus, ou se encontra com precisão absoluta nas obras da doutrina, é evidente que a posição que o Estado assumiu durante esse período caracterizou-se sobremaneira pela sua ausência do domínio econômico. ${ }^{23}$

\footnotetext{
${ }^{23}$ VENÂNCIO FILHO, Alberto. A intervenção do Estado no domínio econômico. Rio de Janeiro: Fundação Getulio Vargas, 1968. p. 4.
} 
O suporte que viabilizou a implantação do sistema de mercado foi o movimento das codificações do direito privado (na França o Code Civil em 1804 e o Code Commercial em 1807). Um sistema fechado de Direito, construído de forma centralizada, no qual o juiz representa o oráculo das leis ("la bouche de la loi" - nas palavras de Montesquieu), vinculado à letra do código perfeito e imutável, devendo manter-se adstrito a mais radical objetividade, observando a lei e somente ela. Um sistema positivo sem lacunas, sem falhas, irretocável - e distante da realidade.

O centro de gravidade desse Estado constitucional, sob a figura de Estado Liberal, fora positivamente a lei, o código, a segurança jurídica, a autonomia da vontade, a organização jurídica dos ramos da soberania, a separação de Poderes, a harmonia e equilíbrio funcional, do Legislativo, Executivo e Judiciário, a distribuição de competências, a fixação de limites à autoridade governante; mas fora por igual, abstratamente, o dogma constitucional, a declaração de direitos, a promessa programática, a conjugação do verbo "emancipar" sempre no futuro, o lema liberdade, igualdade e fraternidade - enfim, aqueles valores superiores do bem comum e da coisa pública, a 'res publica', que impetrariam debate durante a vigência das primeiras Cartas Constitucionais - a sua concretização, invariavelmente negligenciada ou procrastinada em se tratando de favorecer e proteger as camadas mais humildes da sociedade $^{24}$.

Enquanto reluzia o Direito privado, com a criação de uma estrutura legal consistente e lógica com o objetivo de garantir a certeza, a segurança e a liberdade dos negócios entre particulares, o Direito público, por sua vez, não gozou do mesmo destaque devido inclusive à redução do papel do Estado na vida econômica ${ }^{25}$.

Ainda que o Século XIX tenha proporcionado grandes avanços no campo do Direito privado, pois foi durante ele que se consagrou o princípio da separação de poderes e a conquista dos direitos individuais, o fato é que a ordem jurídica prescrevia tais direitos sem que se fosse capaz de concretizá-los de fato.

\footnotetext{
${ }^{24}$ BONAVIDES, Paulo. op. cit., p. 44. Ver também: MARTINS-COSTA, Judith. A boa-fé no direito privado (sistema e tópica no processo obrigacional). São Paulo: Ed. Revista dos Tribunais, 1999. p. 225, "O sistema jurídico é visto de modo fechado, como a concatenação das proposições jurídicas obtidas mediante análise, de tal modo que elas formem, entre si, um sistema de regras logicamente claro, em si logicamente livre de contradições e, sobretudo, sem lacunas, para que todos os fatos da vida tidos como jurídicos possam logicamente subsumir-se numa das normas contidas pelo Código."

${ }^{25}$ Sobre a atuação do Estado, por meio do Direito Administrativo, durante o período liberal, LAUBADÈRE, André de. Droit publique économique. Paris: Dalloz, 1974. p. 31: “Le droit aministratif économique, au sens dún droit doté de règles, notions et instituitions propres, est inexistent en ce que concerne le régime des interventions économiques proprement dites de la puissance publique. Pour ces interventions, en raison même de leur caractère exceptionnel et de leur faible autre que le droit applicable aux tâches administratives traditionnelles de l'Etat et aux formes classiques d'organisation des services public, autrement dit le droit adminstratif commun."
} 
Dos relatos que se tem do período ${ }^{26}$, pode-se concluir que a condição social dos homens das fábricas no auge da Revolução Industrial chegou a níveis degradantes. Especialmente na Inglaterra, verificou-se a marginalização das famílias trabalhadoras, com crianças e velhos em atividades insalubres em troca de remunerações extremamente reduzidas, além do aumento exponencial do número de indigentes.

Antes de adentrar as questões sociopolíticas que mexeram com a sociedade do século XX, cabe mencionar, a seguir, como resultado do florescimento do capitalismo e da especialização das práticas comerciais e financeiras, o sistema do padrão-ouro, pois foi em virtude dessa primeira forma de organização do sistema monetário internacional que ganharam importância os Bancos Centrais.

Nas palavras de Eichengreen, o desenvolvimento do sistema monetário constitui-se essencialmente num processo histórico ${ }^{27}$, cuja análise é imprescindível para a compreensão de tema interdisciplinar e complexo como o papel dos Bancos Centrais.

\subsection{A sustentação do Padrão-Ouro entre os Séculos XIX e XX}

No século XIX, os estatutos monetários de muitos países permitiam a cunhagem e a circulação como meio de pagamento os metais preciosos, ouro e prata, simultaneamente ${ }^{28}$.

\footnotetext{
26،É claro que o trabalhador era explorado em termos econômicos: ele não recebia em troca aquilo que lhe era devido. Todavia, por mais importante que isto fosse, não era tudo. A despeito da exploração, financeiramente ele estava melhor do que antes. Mas um princípio bastante desfavorável à felicidade individual e geral trabalhava na destruição de seu ambiente social, sua vizinhança, sua posição na comunidade, sua profissão, numa palavra, de todas aquelas relações com a natureza e o homem na qual estava embutida a sua existência econômica anterior. A Revolução Industrial estava causando uma desarticulação social de estupendas proporções, e o problema da pobreza era apenas o aspecto econômico desse acontecimento". POLANYI, Karl. op. cit., p. 157.

27، (...) o desenvolvimento do sistema monetário internacional constitui, fundamentalmente, um processo histórico. As opções disponíveis aos países que, em determinado momento, desejam empreender reformas não são independentes dos arranjos monetários internacionais acordados no passado. E os próprios acordos firmados no passado recente refletem a influência de eventos anteriores. Tanto o atual estado de coisas como as perspectivas futuras dessa ordem em evolução não podem ser compreendidas adequadamente sem uma apreciação de sua evolução histórica”. EICHENGREEN, Barry. A globalização do capital: uma história do Sistema Monetário Internacional. Tradução de Sergio Blum. São Paulo: Ed. 34, 2000. p. 27. Considerada a utilização da história como método de pesquisa, vale pontuar ainda um detalhe em relação ao "sistema monetário": na verdade, sistema é um recurso metodológico que ajuda a compreensão da complexa interação de relações sociais. Da noção de sistema decorre que não há uma única relação que exclui todas as demais; assim, o sistema monetário é apenas uma parte da realidade social, bem como o sistema jurídico etc. Nesse sentido, referir-se ao "sistema monetário" implica referir-se ao conjunto de relações envolvendo a moeda dentro do contexto de realidade social analisado em determinado período histórico.

${ }^{28} \mathrm{O}$ bimetalismo foi abandonado definitivamente na década de 1870 . Os países europeus estabeleceram, então, o ouro como a base para seus meios de pagamento e, consequentemente o câmbio fixo baseado no Padrão-Ouro: medida coerente com os ditames da doutrina liberal de priorizar e viabilizar o livre comércio entre os países e, consequentemente, a expansão dos mercados além de suas fronteiras. Sobre o assunto, recomenda-se consultar: EICHENGREEN, Barry. op. cit., p. 29-44.
} 
A Grã-Bretanha, como exceção, já havia adotado o Padrão-Ouro em 1774 (ano em que esse país aboliu o curso forçado das moedas de prata em transações superiores a 25 libras). Os fortes vínculos econômicos de Portugal com a Inglaterra levaram aquele país a adotar do padrão-ouro em 1854.

Os demais países demoraram um pouco mais para unificar a moeda de troca: fariam isso por volta de 1870. Os motivos dessa demora podem ser explicados porque possuir duas opções de padrão monetário para negociar facilitava a tomada de empréstimo no exterior, bem como todas as transações comerciais entre os países. Logo, somente faria sentido a conversão para o monometalismo caso todos os países o fizessem em bloco, ou, ainda, caso um país suficientemente forte adotasse tal padrão.

A Revolução Industrial proporcionou a segunda opção, ao alçar a Grã-Bretanha à mais importante potência econômica do mundo e principal fonte de financiamentos externos. Esse fato ensejou a transição para o padrão-ouro e a definitiva extinção do bimetalismo. Por ter sido a primeira a adotar o monometalismo e a defendê-lo como melhor alternativa, a Grã-Bretanha, após ascender como expoente industrial, atraiu para o padrão-ouro todos os demais países diretamente interessados em estreitar relações econômicas com ela.

Não só a compreensão do funcionamento do mecanismo que sustentou o padrãoouro de 1870 até 1930, como também suas crises e reformulações são essenciais, tendo em vista que a evolução e o colapso desse sistema estão intrinsecamente relacionados com o aprimoramento das atividades dos Bancos Centrais.

El siglo XIX ha visto desaparecer muchos regímenes monetarios y ha visto formarse otros que los siglos precedentes no habían conocido. La concentración de las reservas metálicas en las cajas de los Bancos de emisión y la multiplicación de estos Bancos constituyen ya un fenómeno nuevo. De otra parte se ha visto funcionar al lado del puro patrón oro, del cual Inglaterra dió el premier ejemplo, al bimetalismo y después al patrón cojo (o patrón imperfecto). Se vió nacer una nueva práctica, el Gold Exchange Standard, en el cual la circulación interior de un país, compuesta de plata o de papel, queda unida al patrón oro por el intermedio de un sistema cualquiera de conversión a tipo fijo, con la moneda de otro país. Se vió al papel moneda de curso forzoso producir efectos diferentes en España, en Italia, Estados Unidos, Austria, América del Sur. Se vió al poder de compra de la moneda de plata y después del oro fluctuar de período en período. En una palabra: las experiencias monetarias se han multiplicado y la labor propia de la ciencia económica es tener en cuenta estas experiencias (...). ${ }^{29}$

\footnotetext{
${ }^{29}$ RIST, Charles. Historia de las doctrinas relativas al crédito y a la moneda: desde Jonh Law hasta La actualidad. Tradução de Ernesto Schop Santos. Barcelona: Bosch Casa Editorial, 1945. p. 350.
} 
O padrão-ouro foi instituído com o objetivo de proporcionar uma situação de equilíbrio no cenário econômico internacional, de modo que cada país mantivesse sua base monetária consistente com a paridade cambial. Estaria assegurada, assim, uma balança comercial mais estável. Cada banco era obrigado a converter suas notas bancárias em ouro, sempre que solicitado pelo cliente.

Essa sistemática foi instituída com base no Modelo de Fluxo de Moedas Metálicas de David Hume ${ }^{30}$, por meio do qual ele concluiu que o fluxo de moedas alterava os preços relativos das mercadorias. Logo, se um país fosse superavitário em sua balança de pagamentos, ele receberia ouro dos países deficitários. Isso elevaria sua oferta interna de moeda, gerando uma expansão da base monetária, e, consequentemente, um aumento de preços que tiraria competitividade de seus produtos nos mercados internacionais.

Já se o país fosse deficitário em sua balança comercial, ele enviaria ouro a outros países de modo a adquirir produtos, sofreria contração monetária, seus preços internos seriam reduzidos, o que aumentaria a competitividade de seus produtos no exterior e, consequentemente, ele se recuperaria de seu déficit inicial.

Nesse sentido, o fluxo constante de moedas entre os países levaria os deficitários e superavitários à constante troca de posições ficando sujeitos a permanentes desequilíbrios em sua balança comercial, sendo não só inútil, mas também prejudicial o acúmulo de moedas nos cofres públicos.

Trata-se de uma descrição simples do mecanismo de ajuste do balanço de pagamentos entre países no século XVIII, mas que derrubou a importância dada pelos mercantilistas à acumulação das grandes reservas de metais preciosos como fórmula de enriquecimento. Hume demonstrou, com sua teoria, que um grande tesouro em moeda não traz vantagens duradouras para o país:

\footnotetext{
${ }^{30}$ Partindo de premissas muito simples, considerando um mercado em que circulavam apenas moedas de ouro, Hume desenvolveu o seguinte raciocínio: considerando-se que um determinado país importa mais mercadorias do que exporta - deficitário - em suas transações comerciais ele enviará para outros países, a fim de instrumentalizar o pagamento de suas obrigações, mais moedas de ouro do que as que receberá. Nesse caso, o país tomado como exemplo terá menos moedas de ouro em circulação no mercado interno, o que ensejará diminuição do poder de compra por parte da população e consequente queda nos preços das mercadorias que produzir, dada a redução do consumo. O inverso deverá ocorrer com o país superavitário, pois este terá maior número de moedas de ouro em seu mercado interno, bem como maior disponibilidade monetária nas mãos dos consumidores e, logo, aumento dos preços de suas mercadorias. Segundo a teoria, o equilíbrio entre esses déficits e superávits entre os países restabelece-se ao considerar-se que os indivíduos do país superavitário passarão a comprar as mercadorias mais baratas do país deficitário (pois elas estarão mais baratas) e isso automaticamente aumentará a quantidade de fluxo de moedas no país inicialmente deficitário e diminuirá a quantidade de moedas no país inicialmente superavitário, reequilibrando a balança comercial de cada um. A completa explicação sobre como funcionava o padrãoouro pode ser encontrada na obra de EICHENGREEN, Barry. op. cit., p. 51-57.
} 
Se considerarmos qualquer reino em si, é evidente que a maior ou menor abundância de dinheiro não tem importância: pois o preço das mercadorias é sempre proporcional à abundância do dinheiro ${ }^{31}$.

Obviamente, com o passar do tempo a complexidade dessa sistemática aumentou. Conforme observa Barry Eichengreen ${ }^{32}$, para que a teoria de Hume pudesse acompanhar a evolução da dinâmica de mercado no século XIX, a qual ele mesmo ajudou a transformar, seriam necessárias algumas adaptações.

A primeira diz respeito ao fluxo internacional de capitais, pois esse não estava reduzido à compra e venda de mercadorias; deveriam ser considerados também os empréstimos. Hume, além disso, não tratou do nível da taxa de juros cobrados por tais empréstimos, tampouco sobre a atuação dos bancos - especialmente os bancos centrais nesse cenário, dado que isso era praticamente irrelevante quando formulou sua teoria.

Adicionalmente, a teoria de Hume contava sempre com constantes remessas de ouro que chegariam das colônias para cunhagem e aumento das reservas. Todavia essas remessas, com o passar do tempo e com o esgotamento das reservas naturais das colônias, diminuíram significativamente.

Outra adaptação à sistemática do Padrão-Ouro ocorreu com o aprimoramento da atividade dos bancos centrais. A atuação desses Bancos passou a prescindir da transação física do ouro para a redução dos preços e aumento da competitividade dos produtos domésticos. Os bancos centrais, utilizando-se da taxa de redesconto, operações de mercado aberto ou mesmo intervenção no mercado de câmbio, passaram a cumprir eficientemente esse papel.

A ampliação do modelo de maneira a incluir a intervenção de um banco central visando reforçar o impacto de fluxos de ouro incipientes nos meios de pagamento domésticos podia, assim, explicar como ocorriam ajustamentos externos na ausência de grande movimentação de ouro. ${ }^{33}$

Com efeito, a dinâmica do padrão-ouro, considerada a atuação dos bancos centrais no processo, alterou-se substancialmente, como passar do tempo e a evolução da atividade

\footnotetext{
${ }^{31}$ HUME, David. Apud HUBERMAN, Leo. op. cit., p. 136.

${ }^{32}$ Curiosamente, essas adaptações foram formalmente implementadas no modelo, somente no final da Primeira Guerra Mundial, por meio de um relatório elaborado por uma comissão do governo britânico criada para analisar os problemas monetários do pós-guerra. Para maior detalhamento da teoria, ver: EICHENGREEN, Barry. A globalização do capital: uma história do Sistema Monetário Internacional, cit., p. 52.

${ }^{33}$ Id. Ibid., p. 53.
} 
dos bancos. Todavia isso não foi suficiente para mantê-la em vigor, pois esse padrão monetário não obteve o mesmo sucesso durante o século XX e a explicação para isso está justamente no modo como as autoridades monetárias conduziram a política de conversibilidade e estabilidade das moedas dos respectivos países num século e noutro. Esse ponto é de crucial importância para a compreensão das transformações da política monetária e creditícia daquela época.

A pressão experimentada por governos do século XX para subordinar a estabilidade da moeda a outros objetivos não foi uma característica do mundo do século XIX. O compromisso dos governos em relação à conversibilidade ganhava em credibilidade pelo fato de que os trabalhadores que mais sofriam em conseqüência dos tempos difíceis mal tinham condições de fazer valer suas objeções. (...) O trabalhador que corria o risco de ficar desempregado quando o banco central elevava a taxa de redesconto tinha oportunidades limitadas para fazer ouvir suas objeções e chances ainda menores para demitir de seus cargos os governantes e diretores do banco central responsáveis pela formulação dessas políticas. ${ }^{34}$

A única razão pela qual a política de conversibilidade das moedas manteve-se em vigor até a Primeira Guerra Mundial foi o pacto tácito entre os países dela participantes, sobre a prioridade em conferir segurança e estabilidade ao padrão-ouro. No mercado não pairavam dúvidas de que as autoridades monetárias fariam o possível para manter a conversibilidade da moeda em ouro, em detrimento de todo o resto. Essa certeza gerava segurança quanto à estabilidade desse sistema.

As hipóteses para que o ajustamento automático funcionasse estavam apoiadas no fato de que as economias dos países teriam flexibilidade para movimentar preços e salários. Por ser o auge do Estado Liberal, as autoridades monetárias não deveriam intervir na economia. A responsabilidade principal de um Banco Central naquele período restringia-se a preservar a paridade oficial entre sua moeda e o ouro, sendo todas as demais variáveis facilmente manipuladas em detrimento do alcance desse objetivo.

Por fim, cumpre pôr em relevo o fato de que as recorrentes discussões sobre o padrão-ouro, sua ascensão e queda, usualmente tinham como foco de análise principal a Inglaterra, a grande potência econômica mundial do século XIX, bem como os outros dois líderes da Europa Ocidental, a Alemanha e a França. Além deles, os Estados Unidos, então 
expoentes no cenário econômico, fizeram parte do núcleo-base no que tange às decisões tomadas com relação à estabilidade e conversibilidade da moeda.

Entretanto, países do sul da Europa, como Espanha e Portugal, bem como os países da América Latina acompanharam a questão do padrão-ouro marginalmente, sem exercer qualquer influência sobre as decisões tomadas a respeito do tema. Mas nem por isso deixaram de sofrer os reflexos de tal política.

As perdas de ouro por parte desses países e os problemas na manutenção da conversibilidade da moeda em espécie em ouro eram previsíveis. Em grande parte do mundo, a inexistência dos particulares fatores políticos e sociais que emprestaram ao padrão-ouro sua credibilidade na base do sistema europeu tornou sua operação problemática ${ }^{35}$.

Os países mais periféricos sequer possuíam um verdadeiro sistema financeiro capaz de controlar de forma eficiente os fluxos de moeda e a sua conversibilidade. O Brasil, por exemplo, somente viria a ter um Banco Central com todas as funções que lhe são típicas muito tempo depois. Além disso, na prática, a cooperação entre os países na manutenção da estabilidade monetária, conforme propagava a política da manutenção do padrão-ouro, raramente chegava às fronteiras mais longínquas.

Uma crise no centro financeiro do mundo, como o era a Inglaterra, poderia comprometer irremediavelmente o padrão-ouro. A ajuda externa e a cooperação dos outros países eram frequentemente acionadas ${ }^{36}$. Mas os problemas na periferia não colocavam em risco a estabilidade do sistema e, por isso, os bancos centrais europeus sentiam-se menos inclinados a socorrer o Brasil, ou a Argentina, por exemplo.

A esse respeito, Camargo Vidigal comenta:

\footnotetext{
${ }^{35}$ EICHENGREEN, Barry. op. cit., p. 71.

${ }^{36} \mathrm{~A}$ maior crise de que se tem relato no período, ocorreu em 1890 com o Banco da Inglaterra e chegou a ameaçar a vigência do sistema do padrão-ouro. A crise ocorreu por causa das dificuldades financeiras do banco Baring Brothers que emprestou grandes somas à Argentina e não recebeu o pagamento conforme acordado. O Banco da Inglaterra foi impedido de intervir em favor dos credores daquele Banco, pois isso afetaria seriamente o compromisso do Reino Unido de defender a conversibilidade da libra esterlina, haja vista o volume de drenagem de recursos financeiros que seria necessário para o Banco da Inglaterra agir como financiador de última instância nesse caso. Essa crise somente foi superada com a colaboração dos Bancos da França e da Rússia, que evitaram a superdesvalorização da libra esterlina e o esgotamento de suas reservas por meio de aporte de grandes quantias em ouro a fim de contrapor-se à fuga de capitais estrangeiros ocorrida como efeito da moratória argentina. Sobre esse episódio, vale consultar FORD, A. G. La Argentina y la crisis de Baring de 1890. In: ZAPIOLA, M. G. El regime oligárquico. Materiales para el estúdio de la realidade argentina (hasta 1930). Buenos Aires: Amorrortu Editores, 1975.
} 
As vantagens do padrão-ouro não têm a mesma importância para todos os países. Para um país de economia reflexa e de comércio internacional pouco intenso em relação à atividade econômica doméstica, os atrativos do padrão-ouro não são os mesmos de um país de economia líder, com proeminência no comércio ou na finança internacionais. ${ }^{37}$

Além disso, a teoria do padrão-ouro não considerava o desequilíbrio existente entre as diversas economias integrantes do sistema monetário internacional. A expansão ou contração de economias como a inglesa ou a estadunidense afetava as economias dependentes mais do que os próprios preços ingleses ou americanos.

De todo modo, a pressão generalizada sobre os governos no século XX, para subordinar a estabilidade da moeda a outros objetivos, tais como a priorização do aumento da oferta de empregos, investimentos em obras públicas, fomento ao desenvolvimento de novas atividades econômicas, não existiu no século XIX e foi esse o pilar de sustentação do Padrão-Ouro. No século seguinte, todavia, como será possível identificar, a economia de guerra, bastante peculiar, vem coroar o processo de declínio do Liberalismo e rompe, ao menos temporariamente, com o domínio do pensamento liberal colocando os mencionados objetivos na ordem da vez.

\subsection{As Vicissitudes do Século XX}

Diretamente ligado ao desenvolvimento e consolidação dos Bancos Centrais, o cenário social de transformação verificado no século XX merece destaque.

O século XIX experimentou o auge do liberalismo o qual fez prevalecer os interesses do mercado livre, da acumulação e autorregulação. Não tinham vez, naquele cenário, os pleitos das classes trabalhadoras que certamente eram as mais prejudicadas pelas medidas tomadas para manter em vigor o Padrão-Ouro, as quais tinham como consequência direta o encolhimento das atividades produtivas, o aumento do desemprego e a diminuição dos salários.

Os partidos trabalhistas representantes de tais classes, que tinham por objetivo representar um contramovimento de proteção às instituições sociais deterioradas pelo liberalismo, no século XIX ainda estavam em formação. O direito de voto, por exemplo, na

\footnotetext{
${ }^{37}$ GUDIN, Eugênio. Princípios de economia monetária. 9. ed., Rio de Janeiro: Agir, 1954. v. 2, p.9.
} 
maioria dos países, era privilégio dos homens dotados de propriedades. Assim, não havia representatividade das classes pobres, tampouco oposição intelectual organizada e consente sobre os danos trazidos à sociedade pela priorização da manutenção da conversibilidade da moeda à custa da depressão econômica ${ }^{38}$.

As transformações econômicas e sociais do mencionado século vão alterar profundamente o quadro em que se inseriu o pensamento político liberal. Gigantescas empresas fabris, grandes aglomerados urbanos representaram mudanças determinantes na dinâmica da sociedade europeia do Século XIX.

O colapso social, produto da adoção dos ideais liberais, acabou gerando o efeito reverso: exigiu que o Estado fosse, paulatinamente, abarcando maior número de atividades e intervindo ${ }^{39}$ mais e mais na vida econômica e social a fim de colocá-la nos eixos. Como consequência dessa necessária intervenção estatal, o acesso mais amplo à educação e à informação pelas camadas mais pobres da sociedade possibilitou que houvesse uma participação social maior no processo político.

O Manifesto Comunista de Karl Marx, escrito muito antes, em 1848, serviu como contraponto ao ideal liberal. Como consequência, o intervencionismo estatal ${ }^{40}$, travestido em várias formas, surge das necessidades sociais verificadas no período.

Começa a surgir a noção de que o Estado pode atuar de forma contínua na economia para minorar os conflitos sociais. Ao se estabelecer um conjunto de prioridades,

\footnotetext{
${ }^{38}$ EICHENGREEN, Barry. op. cit.,p. 57-60.

${ }^{39}$ Sobre a questão da "intervenção estatal na economia", GRAU, Eros Roberto. A Ordem Econômica na Constituição de 1988. São Paulo: Malheiros, 2001. p. 21, ensina que se trata do emprego inapropriado da palavra "intervenção", pois dá a entender que o Estado, como organismo alheio à sociedade e ao mercado, intervém em seu funcionamento para controlá-lo e alterar "a ordem natural das coisas". Todavia, afirma ele, sociedade, mercado, Estado e família são manifestações da mesma realidade associativa do homem e devem ser analisadas de forma integrada e não como elementos estranhos pertencentes a realidades distintas. Feita a ressalva, a expressão continuará empregada no decorrer deste trabalho, apenas pelo fato de sua utilização ser a mais comumente adotada pela doutrina.

40، As duas colunas de sustentação teórica desse edifício foram levantadas durante o século XIX, quando o Estado Liberal e seu constitucionalismo doutrinário de separação do Estado e da Sociedade chegavam ao apogeu. A primeira coluna ergueram-na os filósofos políticos do Socialismo Utópico (Owen, Fourier, Saint-Simon, Proudhon), a segunda, os publicistas e pensadores do chamado Socialismo Científico, designadamente seus fundadores, Marx e Engels. A crítica impiedosa ao Capitalismo concluía, no caso dos primeiros, pela reforma social; no caso dos segundos, pela extinção ou desaparição do Estado, por obsolescência, isto é, por se haver tornado supérfluo e anacrônico a partir da apropriação coletiva dos meios de produção. Sua única função consistira em manter, em proveito da classe dominante, a máquina coercitiva da sociedade burguesa e capitalista. Só a luta de classes e as necessidades repressivas do sistema faziam a razão de ser do Estado, mero fenômeno histórico, mero artefato de um processo dialético às vésperas de encerrar-se. Encerramento coroado com o advento da sociedade comunista.O vendaval político-doutrinário que açoitava o Estado constitucional do Liberalismo acabou por convelir os alicerces do Estado de Direito de inspiração individualista e burguês. Despontou, então, a proposta de um modelo de Estado constitucional em que o teor social das instituições se tornava a nota predominante de sua caracterização". BONAVIDES, Paulo. op. cit., p. 47.
} 
a atuação do Estado poderia gerar um resultado útil para sublimar as crises decorrentes do exercício da atividade privada.

O conceito de mercado autorregulável começou a ruir em face de um movimento de oposição de caráter protecionista que se propôs a enfrentar a ação do mercado em relação aos fatores de produção: homem, trabalho e terra. Apoiado na emergência e força desse movimento, o Estado passou a intervir para estancar os excessos cometidos em nome do capital.

Curiosamente, a própria organização do modo de produção capitalista, cujo desenvolvimento automático e espontâneo havia sido tão propagado, teve de sujeitar-se ao controle do Estado - para sobreviver aos males por ele causados.

A análise revela que nem mesmo os adeptos mais radicais do liberalismo econômico puderam fugir à regra que tornou o laissez-faire inaplicável às condições industriais avançadas. No caso crítico da lei dos sindicatos profissionais, e das regulamentações antitrustes, os próprios liberais extremados apelaram para intervenções múltiplas do estado, a fim de garantir pré-condições de funcionamento de um mercado auto-regulável contra acordos monopolistas. Até mesmo o livre comércio e a competição exigiam a intervenção para poderem funcionar(...). Finalmente, o comportamento dos próprios liberais provou que a manutenção da liberdade de comércio - em nossos termos, de um mercado autoregulável - longe de excluir a intervenção, na verdade exigia tal ação, e que os próprios liberais apelaram sistematicamente para a atuação compulsória do estado, como no caso da lei dos sindicados profissionais e das leis antitrustes." 41

Houve, nesse sentido, na conturbada relação entre Estado e mercado um choque entre dois princípios organizadores da sociedade: de um lado, o princípio do liberalismo buscando estabelecer um mercado autorregulável com base no laissez-faire e livre comércio, apoiado pelas classes comerciais e industriais e, de outro, o princípio da proteção social com o objetivo de resguardar a integridade do homem, da natureza e da organização produtiva contra a ação deletéria do mercado.

Esse claro conflito de classes e de objetivos a serem perseguidos levou a uma tensão institucional que culminou com a ascensão do movimento socialista na Rússia e com o movimento fascista na Europa, bem como de outros movimentos radicais os quais

\footnotetext{
${ }^{41}$ POLANYI, Karl. op. cit., p. 182. Nesse, sentido, também esclarece GRAU, Eros Roberto. op. cit., p. 26. “A própria constituição do modo de produção capitalista dependeu da ação estatal. Em outros termos, não existiria o capitalismo sem que o Estado cumprisse a sua parte, desenvolvendo vigorosa atividade econômica no campo dos serviços públicos."
} 
se espalharam, em maior ou menor grau, por boa parte do mundo Ocidental na primeira metade do século XX.

Na verdade, o que se viu naquela época foi a necessidade de se buscar uma solução alternativa ao sistema então vigente. O século XIX encerra-se enfrentando uma grave crise de identidade. O liberalismo começou a dar sinais de enfraquecimento de um lado, e os movimentos populistas voltados a inflamar a grande massa de trabalhadores a buscar seus direitos sociais, levou, de outro lado, à adoção de regimes extremistas.

Sob o testemunho do início do século XX, fruto das convulsões iniciadas no século anterior, emerge a nova experiência do domínio do capital. A sociedade mergulha definitivamente nas questões econômicas que passam a afetar seu cotidiano. Os acontecimentos políticos, tais como a ampliação dos direitos dos cidadãos e o surgimento de partidos operários e sindicatos representativos de classes, possibilitaram a contestação política perante as autoridades monetárias e suscitaram as primeiras discussões sobre a prioridade inconteste dada à conversibilidade das moedas nacionais e ao padrão internacional do ouro.

Como bem anota Eichengreen, muitos bancos centrais e governos começaram a aceitar uma responsabilidade significativa pela estabilidade de seus sistemas bancários na década de 20, como parte da ampliação geral do papel dos governos na regulação da economia $^{42}$. Vê-se uma mudança clara nesse ponto. Trata-se do evidente estremecimento da prevalência da ideologia liberal, até então dominante.

A crescente percepção de que a condição social dos países estaria diretamente relacionada com o equilíbrio econômico interno e externo emprestou cunho político às diretrizes monetárias, que deixaram de ser assunto exclusivamente de interesse dos banqueiros.

A moeda tornou-se o pivô da política nacional. Sob uma economia monetária moderna, ninguém podia deixar de experimentar, diariamente, o encolhimento ou a expansão do bastão financeiro; as populações tornaram-se conscientes do que significava o dinheiro. $O$ efeito da inflação na renda real era descontado adiantadamente pelas massas; em todos os lugares, homens e mulheres pareciam ver o dinheiro estável como a necessidade suprema da sociedade humana. Todavia, essa conscientização era inseparável do reconhecimento de que os alicerces da moeda podiam depender de fatores políticos fora das fronteiras nacionais. Assim, o bouleversement social, que abalou a confiança na estabilidade inerente ao meio monetário, abalou também o conceito ingênuo da

${ }^{42}$ EICHENGREEN, Barry. op. cit., p. 65. 
soberania financeira numa economia interdependente. Daí em diante, as crises internas associadas à moeda tenderiam a levantar graves problemas externos. $^{43}$

Some-se a isso o crescente estranhamento entre os guardiões do sistema do padrãoouro, Alemanha, França e Inglaterra, que culminou com a eclosão da Primeira Guerra Mundial e minou de maneira irreversível a política de solidariedade e de cooperação financeira entre os países aderentes do padrão-ouro.

Embora fosse certa a decadência desse sistema, é preciso ponderar sobre a dificuldade de abandoná-lo. A ideia de que todas as transações financeiras eram pagas com papéis que representavam ouro estava culturalmente disseminada e arraigada entre as grandes potências. A sensação geral era de que a conversibilidade conferia segurança ao negócio.

O ouro simbolizava a existência de um valor representado pelo papel-moeda que, sem ele, nada mais seria do que um papel qualquer, sem significado ${ }^{44}$. Assim, embora tenha havido uma grande crise e a eficácia do padrão-ouro tenha sido colocada em xeque, ao fim da Primeira Guerra sua reinstalação era a prioridade máxima para todos.

Do ponto de vista social, a guerra trouxe como consequência uma grande crise financeira, com altíssima inflação ${ }^{45}$ monetária, classes sociais e nações inteiras espoliadas. Essa crise foi diretamente ligada ao enfraquecimento do Padrão-Ouro.

\footnotetext{
${ }^{43}$ POLANYI, Karl. op. cit., p. 41.

${ }^{44}$ No capítulo seguinte, será analisada a transformação do conceito de moeda. O ouro deixou de ser o seu lastro e a confirmação de que aquele papel poderia servir a todas as finalidades típicas de uma moeda. $\mathrm{O}$ direito passou a fazer esse papel.

${ }^{45} \mathrm{O}$ nascimento oficial da inflação ocorreu nos Estados Unidos durante a Guerra da Secessão, conforme relata em interessante passagem o autor SEDILLOT, René, na obra Onze monnaies plus deux - deux mille ans d'aventure. Paris: Hachette, 1972. p. 64: "Le Nord, industriel et protectionniste, est contre l'esclavage. Le Sud, cotonnier et libéral, est esclavagiste. Lutte d'intérêts. Dans les deux champs, la même question se pose: comment financer la guerre? Chez les Confédérés il n'est de ressource que dans le papier-monnaies. Ils en émettente pour un milliard de dollars, qui se déprecient jusqu'au soixantième de leur parité (...). Chez les Nordistes la convertibilité des billets en espèces est suspendue à la fin de 1861, alors que l'emission n'atteint que 50 millions en demande notes. Deux mois plus tard. le Congrès confère le cours légal au seul papier-monnaie et autorise, après retrait des demande-notes, le lancement de 150 millions de dollars en coupures à dos vert, de 1 a 100 dollars: les greenbaks. De 150 millions le plafond d'emission est relevé par étapes à 250. Ces dollars s'ajoutant à divers billets du Trésor, portant intérêt, à des certificats de dépôt d'or, que servent aussi de moyen de paiement, et aux 300 millions de billets émis par les banques (national bank notes). C'est alors que le mot inflation, que figurait dans le vocabularie médical pour désigner de gonflements (de la rate, de la vessie...) passe dans le langage monétaire. Il apparaît pour la premièr fois, en cette acception, dans un petit ouvrage, signé Alexande Del Mar, que porte pour titre "Un avertissement au peuple: le papier-bulle »( a warning to the people: the paper buble). Sur la couverture, un ballon s'enfle jusqu'au seuil de l'eclatement.
} 
A Guerra representou, também, o declínio das grandes potências da Europa evidenciado pelo ocaso do poderio financeiro e industrial da Grã-Bretanha e pela situação financeira calamitosa verificada na Alemanha ${ }^{46}$ que, de tradicional credora internacional, ao ser massacrada pelas pesadas obrigações impostas pelo Tratado de Versalhes, passou a depender de empréstimos dos Estados Unidos para a manutenção do equilíbrio externo.

De toda maneira, enriquecidas ou empobrecidas, neste momento, todas as forças políticas estavam às voltas com a recuperação do padrão-ouro que seria a solução para o período recessivo que enfrentavam. A crise financeira que atingiu de maneira generalizada as grandes potências mundiais alcançou tamanha proporção que nenhum sofrimento particular, nenhuma violação de soberania era considerada como sacrifício demasiado grande na recuperação da integridade monetária ${ }^{47}$. Até mesmo o abandono dos direitos nacionais e a perda de direitos constitucionais eram considerados preços justos a pagar pelo cumprimento da exigência de orçamentos estáveis e moedas sólidas. Era a porta de entrada para a ascensão de regimes políticos pouco ortodoxos, como o fascismo ${ }^{48}$.

$\mathrm{Na}$ verdade, a essencialidade do padrão-ouro para o funcionamento do sistema econômico internacional da época era o dogma primeiro e único comum aos homens de todas as nações, de todas as classes, de todas as religiões e filosofias sociais. Era a única realidade invisível à qual podia se apegar a vontade de viver, quando a humanidade se encontrava a braços, ela mesma, com a tarefa de restaurar sua existência em frangalhos. ${ }^{49}$

Por um curto período de tempo, de 1924 a 1929, o padrão-ouro foi restaurado com sucesso na grande maioria dos países que adotavam esse sistema e que ansiavam por seu retorno como solução para a recuperação econômica no Pós-Guerra. Todavia, o cenário

\footnotetext{
${ }^{46} \mathrm{~A}$ Alemanha, derrotada na Primeira Guerra, enfrentou uma das inflações mais galopantes das quais se tem registro, especialmente entre 1920 e 1923. Há um interessante artigo, publicado sobre esse tema e - mais especificamente - sobre como John Maynard Keynes contribuiu de forma decisiva para a estabilização do marco alemão, o qual se recomenda consultar. BATISTA JR., Paulo Nogueira. Keynes e a estabilização do marco alemão In: LIMA, Gilberto Tadeu; SICSÚ, João; DE PAULA, Luiz Fernando (Coords.). Macroeconomia moderna: Keynes e a economia contemporânea. Rio de Janeiro: Campus, 1999. p. 340-391.

${ }^{47}$ Conforme será possível verificar, essa mesma história se repetirá no final do século XX e início do século XXI na busca pela estabilidade monetária como política de governo e meta única dos Bancos Centrais.

${ }^{48}$ Fascismo: O amálgama um tanto desconexo das aspirações e influências cristalizadas nos governos de Mussolini na Itália, de Hitler na Alemanha e de Franco na Espanha, na primeira metade do século XX. Alguns de seus elementos são: o nacionalismo; a hostilidade aos ideais de igualdade; o ódio às minorias, aos degenerados e aos dissidentes; o elitismo; a oposição aos ideais do liberalismo, em particular à liberdade de expressão; o culto a um líder carismático; a crença no simbolismo da raça e o amor ao simbolismo político, de que são exemplos os uniformes e outros símbolos militaristas. Essa "mistura", no seu conjunto, é movida pela crença na regeneração por meio da atividade física e da luta. BLACKBURN, Simon. The Oxford dictionary of philosophy. England: Oxford University Press, 1994. p. 144.

${ }^{49}$ POLANYI, Karl. op. cit., p. 42.
} 
político havia mudado $^{50,}$ conforme aqui se mencionou. Manter essa estrutura havia ficado mais caro, pois a manipulação de salários e empregos em nome da estabilidade do PadrãoOuro não era mais tão simples na nova conjuntura social que se formava. A Grande Depressão deflagrada em 1929 foi o ponto final da tentativa de manutenção da conversibilidade monetária em ouro ${ }^{51}$.

$\mathrm{Na}$ década de 1930, os dois países mais poderosos do sistema monetário internacional, Inglaterra e Estados Unidos, abandonaram o Padrão-ouro e começaram a dirigir as próprias moedas, o que significou o abandono do principal pilar do liberalismo econômico por seus mais ricos e respeitáveis seguidores. Nessa mesma década, o socialismo tornou-se uma realidade na Rússia.

Último vestígio da economia mundial tradicional, ao ser abandonado pelos EUA, em 1933, provocou uma verdadeira revolução mundial. Em muitos países o regime liberal foi substituído por totalitarismo e o modo de produção baseado nos livres mercados foi substituído por novas formas de condução da atividade econômica.

Na década seguinte, o liberalismo sofreu outra grande derrota. A Segunda Guerra Mundial levou os países mais influentes ao abandono completo dos dogmas liberais de livre mercado: orçamentos equilibrados, ortodoxia monetária e livre exercício da atividade empresarial.

Em nome da defesa nacional, os governos reconhecidamente liberais assumiram as rédeas do desenvolvimento da atividade econômica por meio do intervencionismo, direcionando, naquele período específico, os investimentos para a indústria bélica. Essa década também presenciou alastramento do movimento fascista em praticamente todo o mundo civilizado ${ }^{52}$.

O Fascismo enraizou-se e ganhou forças por causa da estrutura pouco consistente de uma sociedade de mercado que se recusava a funcionar. Somente alcançou tamanha adesão por representar, naquele momento, uma forma de reação ao sistema em vigor nos

\footnotetext{
${ }^{50}$ Em certo sentido, limites à extensão da democracia substituíram os limites ao grau de mobilidade do capital como fonte de proteção. Com a ampliação do direito de voto e a queda dos controles, essa proteção desapareceu, tornando mais cara e difícil a manutenção do câmbio fixo. EICHENGREEN, Barry. op. cit., p. 253.

${ }^{51}$ Conforme será possível verificar-se no capítulo terceiro, esse período foi determinante para alavancar o processo de industrialização no Brasil.

${ }^{52} \mathrm{O}$ Brasil não ficou à margem do movimento fascista. Vários grupos simpatizantes já se haviam organizado em legiões nos anos de 1920, inspirados em Mussolini. Em 1932, o escritor e jornalista Plínio Salgado fundou a Ação Integralista Brasileira (AIB). Pelo fato de o Brasil ser um país de população miscigenada, o integralismo assumiu, com mais ênfase, o anticomunismo e não o racismo ou o antissemitismo. $\mathrm{O}$ expresidente Getúlio Vargas, como se sabe, nutria notória simpatia pelo regime fascista.
} 
países industriais. Uma verdadeira reação ao capitalismo liberal, o Fascismo pode ser entendido como o contraponto e a solução encontrada diante do status quo da economia de mercado. Desafortunadamente, seu sucesso foi alcançado ao preço da extinção das instituições democráticas, tanto no campo social, como político.

Em 1944, no outro extremo, Fredrich A. Hayek publica a obra "O Caminho da Servidão", com grande repercussão em toda a Europa e também nos Estados Unidos. Nesse livro, Hayek, economista de convicções liberais, utiliza um discurso mais politizado para descrever a situação da Europa nesse período de conflitos mundiais.

Para afastar as influências do sistema totalitário dominante que, na verdade, ele entenderia ser uma evolução do socialismo (as "raízes socialistas do nazismo"), advertiu quanto a seus perigos e poder de manipulação das massas. Defendeu a volta do liberalismo do século XIX como o melhor regime econômico para o desenvolvimento das nações, inclusive no que tange à restauração das relações internacionais.

O fato é que, antes e depois da Segunda Guerra Mundial, as correntes intelectuais fluíam incessantemente em direção ao controle da economia e esse ideal, em algum casos, tomou distintas formas, inclusive algumas delas distorcidas, como foi o caso do fascismo e do nazismo.

Entretanto, Hayek era contra a qualquer ideia de que o futuro deveria ser planejado, criado e dirigido ${ }^{53}$ pelo Estado, pois os entes privados possuíam competência para se orientarem sozinhos buscando um futuro livre e promissor. Logo, em sua opinião, qualquer ideia pré-concebida de sociedade conduziria à tirania e à ditadura.

Conquanto não possamos desejar nem efetuar a volta à realidade do
século XIX, temos a oportunidade de realizar os seus ideais - e esses
ideais não eram desprezíveis. (...) O princípio orientador - o de que uma
política de liberdade para o indivíduo é a única política que de fato
conduz ao progresso - permanece tão verdadeiro hoje como o foi no
século XIX. ${ }^{54}$

Embora seus argumentos tenham ecoado com certa profusão em alguns dos meios intelectuais das nações mais poderosas, não foi dessa vez que o discurso liberal

\footnotetext{
53“Agora, é mais importante remover os obstáculos com que a insensatez humana obstruiu o nosso caminho e liberar a energia criadora dos indivíduos, do que criar novos mecanismos para 'guiá-los' e 'dirigi-los' criar condições favoráveis ao progresso, ao invés de 'planejar o progresso'." HAYEK, Friedrich A. $O$ caminho da servidão. Tradução de Ana Maria Capovilla, José Augusto Stelle e Liane de Moraes Ribeiro. 5. ed. Rio de Janeiro: Instituto Liberal, 1990. p. 214.

${ }^{54}$ Id. Ibid., p. 215.
} 
"repaginado" obteve sucesso. Isso ocorreria somente poucas décadas adiante. O consenso dessa época estava voltado para o planejamento econômico, para a política de pleno emprego, de previdência social e redistribuição da renda.

\subsection{A origem liberal e consolidação intervencionista dos Bancos Centrais}

Antes de se analisar a próxima etapa evolutiva do conflituoso relacionamento entre Estado e mercado, vale abrir um tópico específico na história do capitalismo sobre o surgimento dos Bancos Centrais.

Na Idade Média, no século XV, os bancos em Florença dividiam-se em quatro categorias: banchi de pegno (casas de penhor), banchi a minuto (ourivesaria e comércio de metais e pedras preciosas), banchi in mercato (operações de câmbio realizadas ao ar livre) e banchi grossi (a maior fonte de riqueza da cidade, os banqueiros dessa categoria negociavam mercadorias em local fechado e faziam o câmbio nas principais praças do Ocidente) $)^{55}$.

Como se pode ver, os bancos são um tipo de organização antiga, intimamente ligada ao comércio e ao trânsito de mercadorias, metais preciosos e moedas. Sua função principal e característica, nos primórdios, era ser a instituição depositária de valores, perante os quais emitia os recibos bancários que passaram a ser transacionados, pela corporificação de tais ativos.

Os bancos, portanto, provêm da existência de relações comerciais, nos chamados "atos de crédito" 56 ou "atos de circulação do excedente" por meio dos quais ocorre a transferência de bens ou serviços.

O Banco Central não foi idealizado para cumprir o papel a ele designado, hoje, pelo Estado. Aliás, ele sequer foi idealizado; surgiu, como a maioria das boas invenções, por

\footnotetext{
${ }^{55}$ COMPARATO, Fábio Konder. op. cit., p. 106.

${ }^{56}$ É imprescindível o estudo da disciplina da moeda como suporte à compreensão das ideias desenvolvidas no presente trabalho, pois há relação direta e necessária entre o estudo das atividades desenvolvidas pelo Banco Central e a compreensão da instituição moeda em suas quatro funções: padrão geral de troca, reserva de valor econômico, padrão geral de valor e instrumento de pagamento. "Dans l' histoire du monde, la monnaie tient une place eminente. C'est de son invention et de son apparition que datent les progrès les plus décisives du genre humain. Elle est coup sûr un facteur de civilisation. (...) On n'en finirait pas de recencer les responsabilités de la monnaie dans le déroulement de l'histoire. On aurait tort d'en conclure qu'elle est responsable de tout. Nous ne devons pas plus la glorifier ou l'inculper, que la méconnaître. Parmi d'autres facteurs elle joue son rôle. SEDILLOT, René. op. cit., p. 8-9.
} 
acaso, da necessidade da obtenção financiamento por parte Estado. Sua origem data do final do século XVII ${ }^{57}$, período em que determinados bancos europeus se destacaram em termos de eficiência e relevância econômica. Em decorrência da prestação de seus serviços ao Tesouro, passaram a deter o monopólio de emissão da moeda fiduciária ascendendo, assim, a um patamar diferenciado em relação aos outros bancos privados.

O Banco da Inglaterra diferenciou-se dos demais especialmente por três prerrogativas que lhe foram garantidas no momento de sua criação. A primeira delas era a de realizar operações de emissão de papel-moeda e de títulos à vista; a segunda era a garantia de que os diretores do Banco não teriam de responder com suas fortunas pessoais em caso de falência da instituição; a terceira, a sua constituição como sociedade de ações, o que permitiu que seu capital fosse dividido por numerosos acionistas garantindo ao banco, desde o início, um porte significativo. Nesse período, não existia qualquer controle das atividades financeiras desempenhadas por tais bancos, pelo Estado.

Posteriormente - a partir das atividades assumidas pelo Banco da Inglaterra ${ }^{58}$ - os bancos centrais diferenciaram-se dos bancos comerciais privados na medida em que passaram fixar o valor da unidade monetária de acordo com o metal precioso adotado (ouro, prata ou ambos).

Initially, indeed, the role of Central Banks in maintaining the convertibility of their notes, into gold or silver, was no different, nor seen as any different, from that of any other bank. Their privileged legal position, as a banker to the government and in note issue, then brought about consequently, and, naturally, a degree of centralization of reserves within the banking system in the Central Bank, so it became a banker's bank. It was the responsibility that this position was found to entail, in the process of historical experience that led Central banks to develop their particular art of monetary management ${ }^{59}$.

\footnotetext{
${ }^{57} \mathrm{O}$ primeiro banco tido como central, mas que possuía caráter comercial é o Riskbank sueco, de 1656 . O Banco da Inglaterra em 1694 teve o primeiro direito de emissor de moeda oficial em contrapartida ao empréstimo concedido ao Rei William of Orange para financiamento da guerra entre Inglaterra e França.

${ }^{58 ، L}$ "Los bancos centrales de emisión han tomado en la última parte del siglo XIX una importancia tan grande como punto de apoyo del mercado monetario, que nos es difícil representarnos una época en la cual no existieran. No obstante, a fines del siglo XVIII, en el momento en que formulaban las primeras teorías del crédito, no se conocía más que un Banco de emisión que jugara el papel de Banco central en sentido que hoy se da a este término. Este único Banco era el Banco de Inglaterra. Sólo Inglaterra poseía en aquel momento un verdadero mercado monetario, que era Londres. Los bancos provinciales de emisión, por importantes que fuesen, estaban todos más o menos bajo la dependencia de Londres. El banco de Depósitos de Amsterdam, no es en nada comparable al Banco de Inglaterra. En cuanto a Francia, a pesar del papel centralizador de París y del uso de la letra de cambio sobre París como instrumento general de compensación y de pago, la emisión del billete de Banco estaba limitada a dos o tres Bancos parisienses de importancia secundaria.” RIST, Charles. op. cit., p. 420.

${ }^{59}$ GOODHART, Charles. The evolution of Central Banks. Massachusetts: MIT Press, 1988. p. 5.
} 
Nos anos mais avançados do Século XIX, outras atividades foram agregadas à manutenção da conversibilidade da moeda, as quais paulatinamente se tornaram imprescindíveis ao bom funcionamento do sistema financeiro. O Banco Central passou a ser o banco dos bancos e a atuar como câmara de compensação de títulos e notas bancárias. Mas, ainda nessa fase, o Estado era nada mais do que um bom cliente.

Na Europa, além do Banco da Inglaterra, o Banco da França ocupou lugar de destaque logo no início de sua concepção, devido à grande reserva metálica que possuía em seus cofres. Entre 1850 e 1870, o segundo mercado monetário e financeiro do mundo foi o francês. Quanto aos demais países do continente europeu, tinham mercados demasiado pequenos e os respectivos sistemas bancários demoraram mais a se consolidar.

A partir de 1871, nasce um novo e potente mercado monetário em Berlim, o Reichsbank toma lugar de destaque entre os bancos centrais europeus. Posteriormente, Itália, Áustria, Suíça, Países Escandinavos e, por fim, a Rússia criaram seus próprios bancos centrais. Já o Federal Reserve System, somente foi criado em $1913^{60}$, após uma grande crise no sistema bancário dos Estados Unidos em 1907.

Em finais do Século XIX, inaugurou-se a atividade de "redesconto" tão típica dos bancos centrais, mecanismo que funcionava com os bancos emprestando dinheiro aos comerciantes por um prazo que usualmente variava entre 60 e 90 dias. O banco central poderia adiantar o dinheiro desse empréstimo em troca do pagamento de juros e da transferência do crédito instrumentalizado por meio de um título. Essa operação, denominada de "redescontar o título", tinha uma taxa de redesconto, que representava, na verdade, os juros cobrados pelo crédito concedido.

A taxa de redesconto era o mecanismo mais utilizado pelos bancos centrais para controlar a expansão da contração do crédito no mercado interno e, assim, restaurar o equilíbrio da balança de pagamentos sem a transferência de ouro.

\footnotetext{
${ }^{60} \mathrm{O}$ Federal Reserve System será analisado com mais profundidade no Capítulo II deste trabalho, mas cumpre destacar que, quando os Estados Unidos decidem criar o próprio banco central (ou, mais exatamente, doze bancos centrais organizados e dirigidos por uma autoridade central), verifica-se o princípio da unificação e consolidação dos grandes mercados monetários nacionais. "Pero la crisis de 1907 ha tenido por efecto principal la creación de Bancos federales de Reserva en los Estados Unidos y la claridad incomparable con la cual la noción de Banco central ha sido deducida en esta ocasión. Por la primera vez en la doctrina económica se ha visto a la concepción de Banco central ligada, no a la idea de la emisión del billete, sino a la idea de concentración de las reservas metálicas. Lo que la evolución espontánea de los mercados en Francia e Inglaterra había obligado a ser al Banco de emisión (reserva metálica del país) es desde ahora en adelante considerado como el objeto mismo de un Banco central y la emisión de los billetes no es más que uno de los métodos que un Banco central puede emplear para cumplir esta función esencial.". RIST, Charles. op. cit., p. 466-467.
} 
O Banco Central moderno foi, de fato, um artifício desenvolvido basicamente com $\mathrm{o}$ propósito de oferecer proteção [contra o funcionamento irrestrito do mecanismo de mercado] e sem ele o mercado teria destruído seus próprios filhos, as empresas comerciais de todos os tipos. $^{61}$

A criação dos bancos centrais e o seu funcionamento despertaram importantes discussões doutrinárias dos parlamentos às academias. As funções e o papel desses bancos nas economias nacionais tornam-se objeto de estudo e interesse dos homens de estado e do público em geral.

Embora se tenham proliferado pelas nações do globo entre o fim do século XIX e início do século $\mathrm{XX}$, somente se consolidaram como instituições essenciais ao sistema monetário com as Guerras Mundiais, quando, em nome do Estado, passaram a intervir e controlar as finanças voltadas para a atividade bélica.

Assim, no início do século XX, enquanto durou a Primeira Guerra Mundial, suas atividades concentraram-se basicamente em financiar os gastos bélicos dos Estados. Depois da guerra, uma nova escalada no desenvolvimento dos bancos centrais aconteceu, pois deixaram de ser meros estabelecimentos de crédito comercial para se tornarem emissores de papel moeda e financiadores da atividade intervencionista do Estado.

A adoção por uma entidade governamental da função de controlar os mecanismos monetários ${ }^{62}$ dotava o governo de instrumento de interferência no mercado e possibilitava desenvolver um planejamento em relação a conflitos/guerras. $O$ que se desenha nas primeiras quatro décadas do Século XX é o Banco Central com função de reserva, quando passou a concentrar as divisas, os depósitos compulsórios retirados do mercado para financiar o próprio Estado e para controlar o crédito.

A função de casa da moeda, responsável pela criação primária do instrumento monetário dá-se mediante a concessão de crédito. Os bancos de depósitos mantêm contas no Banco Central e mediante essas contas, fazem depósitos compulsórios, compensação de saldos e reservas de créditos. Na medida em que o Banco Central planeja emissão monetária, credita a conta do Estado e os recursos que circulam na sociedade impactando a

\footnotetext{
${ }^{61}$ POLANYI, Karl. op. cit., p. 228.

${ }^{62}$ Antes de a emissão de moeda ser uma função estatal, havia multiplicidade de padrões de valores. Isso dificultava o poder tributário e a tutela das divisas (câmbio). Após 1929, há um movimento da quase totalidade dos Estados no sentido de estabelecer a uniformidade do padrão de valor, não só para acolher a função de instrumento de troca e curso forçado, mas também para ser padrão de valor. Assim, todas as relações deveriam ser medidas segundo esse padrão definido pela lei do Estado.
} 
economia. Quando há necessidade de ser fazer um pagamento e não há fundos para uma despesa estatal, há emissão monetária. O Banco Central, como banco de emissão, passou a desempenhar, assim, essa função de emissor creditando as contas de reservas bancárias para atender as políticas estatais.

A emissão monetária do Banco Central, portanto, dá-se pelo crédito em contas de reservas bancárias, para atender a despesa do Estado. Uma vez feito esse crédito, a decorrência é a expansão dos meios de pagamento.

Assim, ao encaminhar, por exemplo, o crédito para a atividade agrícola, o que se espera é a expansão da atividade agrícola, o mesmo vale para os mais diversos setores produtivos da economia. Por isso, nessa etapa, o crédito ajusta-se ao instrumento de política pública, e ganha destaque no funcionamento da sociedade.

Uma vez organizado no plano da administração pública, o produto social e a renda social ganham maior importância como variáveis a ser consideradas no desenvolvimento da política monetária. A renda poupada, depositada nos bancos comerciais, com a interferência do Estado, passa a ser direcionada para investimento ou para consumo, conforme a orientação da política pública e vira produto consumido ou produto investido. A função do crédito como instrumento da ação governamental é justamente este: direcionar o crédito para investimentos e consumo.

Ao impor-se o governo na função de planejar, o Banco Central passa a orientar o crédito, segundo os desígnios das políticas traçadas, um órgão-chave na execução do planejamento econômico. Nesse sentido a função de emissão ao concentrar-se no governo, confirma o afastamento da ideologia do Estado utópico do ideal liberal. O planejamento e atuação do Estado tornaram-se eram indispensáveis. A função de planejar era decorrência da gestão monetária.

Especialmente no que tange ao novo papel desenvolvido pelo Estado, André de Laubadère, na obra Droit Publique Economique, como fundamentos a necessidade de modernização e expansão da economia:

Mais l'avènement du rôle bancaire de l'Etat repose aussi sur des raisons plus profondes, à savoir la conscience de la nécessité d'un effort de modernisation et d'expansion de léconomie auquel on estima que l'État devrait concourir en aidant les invstissements par des prêts publics ${ }^{63}$.

\footnotetext{
${ }^{63}$ LAUBADÈRE, André de. op. cit., p. 41.
} 
Ao buscar financiamento no mercado para o déficit orçamentário, o Estado tem características ímpares, pois não vai à falência, não se sujeita a concurso de credores, possui as inesgotáveis receitas tributárias. Nesse sentido, trata-se de um devedor preferencial em relação aos demais. Em vez de se emprestar para o consumidor ou para o empresário, empresta-se para o Estado, pois ele sobrevive a todas as crises e não está sujeito às oscilações da economia a que estão sujeitos todos os entes da esfera privada.

Verifica-se, portanto que o Estado, na qualidade de peculiar devedor, ao ofertar seus títulos ao sistema bancário, tem preferências por suas qualidades. Esses títulos estabelecem um patamar de juros, com base nos quais as demais modalidades de créditos se acomodam. Quanto maiores os juros que o Estado paga, mais depósitos são aplicados para a subscrição de papéis do governo. O recurso retirado implica a redução da moeda escritural para ampliação do crédito. Em sentido inverso, se o Estado oferece títulos com deságio vantajoso, os recursos são drenados para o sistema bancário, ampliando a concessão de crédito.

Com a aplicação de taxas atraentes, os Bancos Centrais controlaram a ampliação ou contração do crédito bancário com a venda de títulos estatais. Este é o princípio do open market sobre o qual se discorrerá no capítulo seguinte. $\mathrm{O}$ efeito pretendido é a ampliação ou contração das possibilidades de crédito bancário, tendo em vista o planejamento da atividade estatal $^{64}$.

No Pós-Segunda Guerra, os Bancos Centrais definitivamente assumiram o papel de autoridade monetária e passaram a englobar, em suas atividades, o fornecimento de empréstimos de liquidez para atender as necessidades das instituições financeiras, o controle das reservas internacionais e a atuação para promover o funcionamento regular do mercado cambial e do equilíbrio do balanço de pagamentos.

Assim, a política econômica exercida pelo Estado hoje se apoia na política monetária como um de seus principais alicerces e o exercício dessa política, por determinação legal, dá-se por meio do Banco Central.

\footnotetext{
${ }^{64} \mathrm{O}$ problema ocorre quando os bancos oferecem taxas tão atrativas para o financiamento de suas atividades que passa a representar concorrência desleal àqueles que pretendem desempenhar atividade produtiva no setor privado, pois o preço da captação dos recursos (crédito) passa a pautar-se pelas taxas oferecidas pelo estado.
} 
Embora tenham sido aventadas, no passado, hipóteses de extinção dos bancos centrais $^{65}$, a verdade é que não se pode imaginar o cenário econômico atual sem a participação dessa figura. De mero coadjuvante, no início, passou a ocupar posição-chave no controle da atividade econômica dos países.

\subsection{O Direito no Estado Intervencionista}

Conforme visto, o Direito regulador das relações sociais que emergiu com o modo de produção capitalista no Século XIX é racional e positivo, "todos são iguais perante a lei" ainda que sociamente muito distintos. Verdadeiro oposto do Estado Absolutista que vigorou no período anterior, durante o mercantilismo, esse direito voltado a legitimar a política liberal, visava possibilitar o livre desenvolvimento das relações de mercado.

Conforme Eros Grau, a concepção de Estado, segregada da concepção de sociedade como se fossem duas coisas totalmente apartadas, foi corrigida somente a partir do Século XX.

Tem-se afirmado que ao Estado, até o momento neoconcorrencial ou intervencionista - qualquer que seja o vocábulo ou expressão que se adote para designar a mudança de regime que marca, no sistema capitalista, a passagem do Século XIX para o Século XX - estava atribuída, fundamentalmente, à função de produção do direito e segurança. Para referir, em largos traços, o regime anterior, poderíamos afirmar, singelamente, que não se admitia interferisse o Estado na "ordem natural" da economia, ainda que lhe incumbisse a defesa da propriedade. Essa concepção porta em si pressuposição de que ambos, Estado e sociedade, existissem separadamente um do outro, o que não é correto ${ }^{66}$.

\footnotetext{
${ }^{65}$ GOODHART, Charles. op. cit., p. 13-28, destaca que a teoria do Free Banking encontra adeptos desde 1860 e teve como seus principais representantes W. Bagehot na França e Henry Thorton na Inglaterra; posteriormente (1986) Fredrich Hayek retomou o tema propugnando pela desnacionalização do dinheiro: "Initially Hayek thought that it might be sufficient, as a constraint on national overissues of money, to allow and to encourage competition between national currencies, e.g., by removing all exchange controls and allowing any contract to be legally conducted in any currency (...) Subsequently, however, he went on to propose the more radical step of allowing and encouraging private note issuers to compete. This proposal was, in general, akin to the suggestions for free banking, as considered earlier by Bagehot et al. in the nineteenth century. In such a system of 'free banking' there would be no Central Bank and no reservoir of reserves: each individual bank would be responsible for keeping its own reserves and the convertibility of its own note and deposits liabilities” HAYEK, Friedrich A. op. cit., p. 25.

${ }^{66}$ GRAU, Eros Roberto. op. cit., p. 18.
} 
Com efeito, no início do Século XX, mais precisamente a partir da Primeira Guerra Mundial, houve uma revolução no modo de pensar, na concepção das instituições, na ciência jurídica e no modo de organização da sociedade.

Os Estados, perfeitamente configurados (Pós-Revolução Francesa), vão ilustrando a preocupação dos governos em disporem de rendas necessárias para alimentar a máquina de guerra e, principalmente, não chegar à hipótese insustentável de que o governo ficasse na dependência de moedas de seu opositor.

André de Laubadère ${ }^{67}$ divide as formas de intervenção do Estado na economia e as consequentes transformações da ciência do direito em três etapas, o período anterior à Primeira Guerra Mundial, o período entre as Guerras Mundiais e o período Pós-Segunda Guerra Mundial.

Antes da Primeira Guerra, o Direito Público, ofuscado pelo agigantamento do Direito Privado, estava adstrito à regulação do estabelecimento de taxas e a organização dos serviços públicos, de acordo com o direito administrativo comum. O Estado, portanto, era mero mantenedor da ordem constituída, a qual propugnava pelo livre comércio e pela não intervenção.

No período entre guerras, a crise econômica de 1929 foi decisiva para o avanço do intervencionismo e para sepultar o Estado Liberal, na medida em que se fez necessária a intervenção estatal para impulsionar a atividade econômica e recuperar os países imersos na pobreza do pós-guerra.

No período Pós-Segunda Guerra constrói-se uma etapa fundamental do direito público. Nas palavras de André de Laubadère:

Ils n'ont pourtant pas été sans lendemain et, de ce fait, la période 19351945 a constitué une étape dans la formation du droit public économique: Au point de vue de l'extension du champ d'application de l'interventionnisme, la période de guerre et de pénurie a ouvert à l'interventionnisme des secteurs qui ne lui ont plus été fermés depuis lors. $(\ldots)^{68}$.

\footnotetext{
${ }^{67 " R e t e n e n t ~ d o n c ~ i c i ~ l a ~ n o t i o n ~ d e ~ d r o i t ~ p u b l i c ~ d e ~ l ' e ́ c o n o m i e, ~ o n ~ p e u t ~ o b s e r v e r ~ q u e ~ l ' o b j e t ~ e s s e n t i e l ~ d e ~ c e ~ d r o i t ~}$ est constitué par l'intervention de l'État (ou autres personnes publiques) dans l'économie. Le droit publique économique est ainsi le droit applicable aux interventions des personnes publiques dans l'économie et aux organes de ces interventions." LAUBADÈRE, André de. op. cit., p. 20.

${ }^{68}$ Id. Ibid., p. 37.
} 
A economia passou, portanto, do protecionismo comercial ao dirigismo estatal. $\mathrm{O}$ setor público alcançou enorme desenvolvimento comercial e industrial e foi nesse período, conforme destaca André de Laubadère, ${ }^{69}$ que surgiram as sociedades de economia mista, reunindo capitais públicos e privados para atuarem na atividade produtiva. Nessa fase, o direito público renova-se para regular a estruturação e organização de um novo tipo de Estado, muito mais forte.

Ora, o que caracteriza a política econômica do Estado contemporâneo, tanto a Leste quanto a Oeste, não só nas sociedades industrializadas como nos países subdesenvolvidos, é o objetivo de expansão ${ }^{70}$.

Verifica-se, portanto, que os tais fatos históricos consecutivos que convulsionaram as nações mais ricas do globo trouxeram em seu bojo uma série de mudanças, entre elas, passou a ser repensado o direito e, mais precisamente, a regulação das relações entre o Estado e o mercado.

Fabio Konder Comparato ${ }^{71}$ destaca a revolução social a partir da eclosão da Primeira Grande Guerra. Pelo fato de todas as funções do Estado passarem a concentrar-se na economia bélica, inaugura-se uma nova concepção de direito que deverá reger as relações econômicas - as forças produtivas passam a concentrar-se no objetivo único do Estado - vencer a guerra.

Surgem, então, com a Primeira Guerra, as necessidade de reestruturação dos poderes do Estado, com uma elevação do direito público comparativamente ao direito privado. A necessidade de justificar o aumento do Poder do Executivo face ao Legislativo e Judiciário, dado que aquele passa a ser o encarregado de reestruturar as nações solapadas pela guerra, gerou as primeiras reflexões sobre o Direito Econômico.

O que inicialmente se cogitou ser apenas um direito bélico, com data certa para deixar de reger as relações sociais, prolongou-se de forma irreversível transformando-se no direito da economia - o Direito Econômico, nas palavras de Comparato, o "corolário indispensável da constituição do Estado pós-liberal”.

\footnotetext{
${ }^{69}$ En ce qui concerne l'économie mixte, constituée par la réunion de capitaux publiques et de capitaux privés au sein de societés mixtes, la période de l'entre-deux guerres a été encore plus importante car c'est alors que cette formule a pris naissance(...).LAUBADÈRE, André de. op. cit., p. 33.

${ }^{70}$ COMPARATO, Fábio Konder. O indispensável direito econômico. In: direito empresarial. Rio de Janeiro: Forense, 1978. p. 464.

${ }^{71}$ Id. Ibid., p. 453 e ss.
} 
Conforme aponta Bercovici, por todo esse contexto social de transformação em que foi concebido, o direito econômico não é um mero ramo do direito formal facilmente classificável de acordo com determinados parâmetros e características previamente definidas nas quais se possa encaixar. Não pode ser rotulado de acordo com as matérias que regula, tal como foi feito com os demais "ramos do Direito" durante o período liberal. Justamente por ter nascido de um momento de crise e revisão dos métodos jurídicos tradicionais, o direito econômico deve ser compreendido de acordo com o contexto histórico em que surgiu.

Diferentemente do direito privado, que passou por uma fase bastante profícua durante o período liberal, especialmente no que concerne ao movimento das codificações que levaram os juristas a meros intérpretes das leis escritas, o direito econômico não é simplesmente técnico, mas político e encontra suas raízes nas questões sociais de seu tempo.

\begin{abstract}
Neste contexto de ebulição social, o resultado será uma alteração profunda nas estruturas constitucionais e estatais. A constituição de Weimar, de 1919, não representa mais a composição pacifica do que já existe, mas lida com conteúdos políticos e com a legitimidade, em um processo contínuo de busca de realização de seus conteúdos, de compromisso aberto de renovação democrática que visava à emancipação política completa e à igualdade de direitos, incorporando os trabalhadores ao Estado. Não há mais constituições monolíticas, homogêneas, mas sínteses de conteúdos concorrentes dentro de um quadro de um compromisso deliberadamente pluralista. A constituição é vista como um projeto que se expande para todas as relações sociais. O conflito é incorporado ao texto constitucional que não representa mais apenas as concepções da classe dominante, pelo contrário, torna-se um espaço onde ocorre a disputa político-jurídica ${ }^{72}$.
\end{abstract}

Trata-se de uma nova concepção do direito sobre a qual foi possível conceber um novo tipo de relação entre Estado e economia.

Com efeito, a presença do estado na ordem econômica com o objetivo de organizar os mercados fez-se essencial com compreensão geral de que somente ele seria capaz de promover e garantir, de um lado, a consecução dos ideais sociais de bem-estar e desenvolvimento e, de outro assegurar, dentro de certos limites, a liberdade de ação dos agentes de mercado. A experiência dos conflitos mundiais possibilitou essa compreensão.

${ }^{72}$ BERCOVICI, Gilberto. op. cit., p. 511. 
Esse novo direito ecônomico concebe a ordem jurídica que conformará o novo modelo de estado - o Estado-Providência.

\subsection{Bretton Woods e o Estado-Providência}

Como visto, o produto das convulsões, iniciadas pelos contramovimentos sociais, políticos e intelectuais contra a desintegração das relações humanas sob a égide do sistema liberal, consolidou-se no Pós-Segunda Guerra. O mundo estava, enfim, preparado para aceitar uma nova realidade.

Houve claro afastamento dos princípios liberais que dominaram os ideais das potências mundiais até então. O poder público passou a intervir fortemente na vida privada com o objetivo de garantir o bem-estar da sociedade ${ }^{73}$.

Consolidou-se o predomínio político, industrial e financeiro dos Estados Unidos da América $^{74}$ que enriqueceram, especialmente, com o comércio de armas e com a concessão de crédito aos outros combatentes da Guerra e, com isso, construíram uma sólida indústria manufatureira.

Claus Offe, ao explicar o Welfare State Keynesiano ${ }^{75}$ e o boom econômico amplo e sem precedentes que favoreceu todas as economias capitalistas avançadas, destaca que as

\footnotetext{
73،“Crescimento da produção, pleno emprego e difusão de benefícios por meio do Estado se tornaram valores correntes não só nos países desenvolvidos, mas também no mundo em desenvolvimento. O poder público deveria não só administrar os mecanismos de segurança social, como salário-desemprego e assistência médica, mas também atenuar, por meio da tributação progressiva e do gasto orçamentário, as desigualdades não corrigíveis pelo mercado - ou causadas e acentuadas por sua operação. Tudo isso pode soar de forma incompreensível para um jovem nascido nos anos de 1970 ou 1980 e instruído na filosofia liberal do 'salvese quem puder'. KUNTZ, Rolf. Estado, mercado e direitos. In: AMARAL JR., Alberto do; PERRONEMOISÉS, Cláudia (Orgs.). O Cinqüentenário da Declaração Universal Dos Direitos Do Homem. São Paulo: Edusp, 1999. p. 349.

${ }^{74}$ Nesta trajetória, é importante observar a ascensão dos Estados Unidos à condição de potência hegemônica do sistema, reagindo à crise dos anos trinta com um novo paradigma de governo - o New Deal - e construindo a ordem internacional do pós-guerra de acordo com seus interesses político e econômicos. MASSONETTO, Luís Fernando. O direito financeiro no capitalismo contemporâneo: a emergência de um novo padrão normativo. 2006. Tese (Doutorado) - Faculdade de Direito da Universidade, São Paulo, USP, São Paulo, 2006. p. 31.

75، A economia capitalista, e esta é a lição a ser aprendida com o keynesianismo, é um jogo de soma positiva. Assim, jogar num jogo de soma zero seria jogar contra os próprios interesses. Isto quer dizer que cada classe tem que levar em consideração os interesses de outra classe: os operários, a lucratividade porque somente um nível de lucro e de investimento razoável garantirá o emprego futuro e o aumento da renda, e os capitalistas, os salários e as despesas do Welfare State, porque são estes que garantirão uma demanda efetiva e uma classe operária saudável, bem treinada, sem problemas de moradia e feliz". OFFE, Claus. Problemas estruturais do Estado capitalista. Tradução de Barbara Freitag. Rio de Janeiro: Tempo Brasileiro, 1984. p. 375 e 374.
} 
razões desse sucesso podem ser explicadas pelo fato de tratar-se de um modelo pacífico de conciliação entre o modo de organização da economia de mercado - o capitalismo - e a forma de organização do poder político - a democracia. As condições para a aceitação do Welfare State Keynesiano estariam intimamente ligadas ao consenso social, Pós-Segunda Guerra Mundial, quanto à priorização do desenvolvimento econômico e da segurança nacional.

De fato, a recuperação financeira dos países destruídos pela Segunda Guerra somente foi possível com a decisiva colaboração dos Estados Unidos para a regeneração das economias europeias, colaboração esta que também foi de enorme valia aos interesses expansionistas norte-americanos.

O programa de cooperação e recuperação que lançou as bases de um novo sistema monetário internacional, aprovado na Conferência de Bretton Woods (abril/junho de 1944), foi idealizado pelos economistas John Maynard Keynes e Harry Dexter White ${ }^{76}$.

Keynes, o maior e mais eficiente crítico do liberalismo clássico, manteve-se fiel aos objetivos fundamentais eternizados em suas obras ao apresentar seu plano em Bretton Woods: um mundo sem desemprego, sem grandes desigualdades entre as classes sociais e entre as nações, com base na gestão racional da economia pelos Estados ${ }^{77}$.

A ideia não seria abandonar os padrões então vigentes do capitalismo, mas romper os limites do atraso e da pobreza por meio da intervenção do Estado a fim de multiplicar as oportunidades e de promover o bem-estar. Tentava-se nesse momento a conciliação entre o Estado e o mercado, sendo aquele o promotor do desenvolvimento deste.

\footnotetext{
76، A Bretton Woods, que n'est guère qu'un grand hôtel dans une forêt de sapins proche de la frontier canadienne, l'Amerique convie les Nations Unies, en juillet 1944, à élaborer une charte des monnaies. Quarante-quatre nations y sont répresentées, deux seulement le jeu: les deux nations anglo-saxonnes, celle $d u$ sterling, monnaie dominante d'hier, celle du dollar, monnaie dominante de demain. La conference s'achève sur un copromis, plus proche du projet américain que du projet britannique. " J' étais venu avec un pur-sang, declare Keynes; je repars avec un animal issu du croisement d'un pur-sang et d'un mouton ». Mais le pur-sang de Keynes était tout prêt à désarçonner ses cavaliers; le mouton de White est plus rassurant." SEDILLOT, René. op. cit., p. 269.

77،"Ficava assim legitimada a intervenção do estado na busca de maior justiça social, de maior igualdade entre as pessoas, os grupos e as classes sociais. A "equação Keynesiana” foi uma tentativa de consolidar o progresso social e a eficácia econômica. E o discurso keynesiano tornou claro que a conciliação destes dois objectivos (em vez da proclamação de sua natureza conflituante) é uma necessidade decorrente das estruturas econômicas e sociais do capitalismo contemporâneo. A esta necessidade, respondeu, a partir dos anos 30, e, mais acentuadamente, a partir da Segunda Guerra mundial, a criação do estado providência, assente na intervenção econômica, na distribuição da riqueza e do rendimento, na regulamentação das relações sociais, no reconhecimento de direitos econômicos e sociais aos trabalhadores, na implantação dos sistemas públicos de segurança social.” NUNES, António José Avelãs. op. cit., p. 34.
} 
O Estado deverá exercer uma influência orientadora sobre a propensão a consumir, em parte através de seu sistema de tributação, em parte por meio da fixação da taxa de juros e, em parte, talvez, recorrendo a outras medidas. Por outro lado, parece improvável que a influência da política bancária sobre a taxa de juros seja suficiente por si mesma para determinar um volume de investimento ótimo. Eu entendo, portanto, que uma socialização algo ampla dos investimentos será o único meio de assegurar uma situação aproximada de pleno emprego, embora isso não implique a necessidade de excluir ajustes e fórmulas de toda a espécie que permitam ao Estado cooperar com a iniciativa privada. ${ }^{78}$

A Teoria Geral do Emprego, do Juro e da Moeda, publicada em 1936, momento em que o mundo encontrava-se assolado pela grande depressão, buscou demonstrar, contrariando o pensamento econômico/político dominante, que os princípios basilares da escola clássica não poderiam aplicar-se adequadamente à experiência concreta, por partirem sempre de situações de equilíbrio enquanto o mundo fático, ao contrário, demonstrava-se permanentemente instável.

Partindo do pressuposto de que o sistema capitalista tem caráter intrinsecamente instável, é possível concluir que a mão invisível não produz a harmonia apregoada entre os interesses egoístas dos agentes econômicos e o bem-estar global. Em busca de seu ganho máximo, o comportamento individual dos agentes econômicos - produtores, consumidores, assalariados - pode gerar crises, a despeito do bom funcionamento das forças automáticas dos "mercados livres".

Nesse sentido, a intervenção torna-se necessária, pois, sem a presença de um Estado atuante, não é possível controlar as variantes que desestabilizam as economias dos países e geram as crises, as deficiências estruturais e o desemprego. Esses ideais foram, de uma forma ou de outra, observados no momento da estruturação de uma nova ordem mundial.

Lord Keynes acreditava que um sistema monetário internacional ideal seria

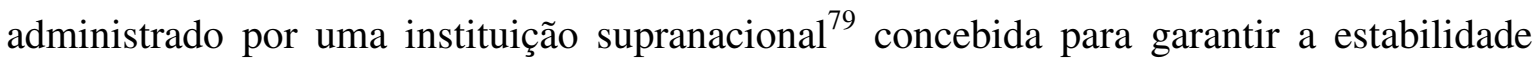
monetária e para superar as limitações sofridas no período do padrão-ouro. Seria um tipo de "banco central mundial" com a competência para emitir um ativo fiduciário escritural hábil para servir como reserva legal do sistema. Note-se que de acordo com o plano inicial

\footnotetext{
${ }^{78}$ KEYNES, John Maynard. A teoria geral do emprego, do juro e da moeda. Tradução de Mário R. da Cruz. 2. ed. São Paulo: Nova Cultural, 1985. p. 256. (Série Os Economistas)

79،“A concepção de um banco supranacional vinculava-se às seguintes preocupações: (i) garantir mecanismos mais flexíveis de ajustes e provisão da liquidez entre países superavitários e deficitários em âmbito internacional; (ii) eliminar a assimetria nos ajustes de balanço de pagamentos entre países, decorrente da sua posição na hierarquia de moedas." PRATES, Daniela Magalhães; CINTRA, Marcos Antônio Macedo. Keynes e a hierarquia de moedas: possíveis lições Para o Brasil. Campinas: Instituto de Economia, Unicamp, 2007. n. 137, p. 6.
} 
não haveria uma moeda tangível, real para ser entesourada, tampouco haveria a possibilidade de que uma nação, por ser a emissora de tal moeda, exercesse seu domínio e sua influência sobre as demais, justamente por controlar o padrão monetário internacional.

Esse ativo fiduciário supranacional poderia ser utilizado para administrar as balanças de pagamentos, as necessidades de liquidez do comércio internacional e, assim, auxiliar os países a manterem seu equilíbrio econômico. Com isso, os ajustes deflacionários seriam evitados e as economias nacionais poderiam sustentar suas trajetórias em direção ao pleno emprego, sem que para isso tivessem de criar relações de dependência predatória com países de economia mais forte.

Claro que a realidade não refletiu exatamente esse modelo idealizado por Keynes, porque White apresentou, inclusive, outro plano e, na qualidade de representante dos Estados Unidos, a grande potência mundial emergente do Pós-Segunda Guerra defendeu o dólar como a moeda-chave no sistema, institucionalizando o Padrão-Ouro-dólar e consolidando a hegemonia norte-americana no âmbito monetário internacional.

Conforme destaca Robert Solomon, na Conferência de Bretton Woods, evento em que se materializou o plano econômico internacional resultante da parceria Keynes/White, foram fixadas as seguintes condições que deveriam ser cumpridas pelos países que desejassem integrar o novo sistema monetário internacional: seria criado um Fundo Monetário Internacional (FMI), instituição da qual os países aderentes a Bretton Woods deveriam ser membros e cujas diretrizes deveriam observar; as taxas cambiais seriam fixas, porém reajustáveis; as moedas dos países deveriam ser conversíveis entre si; o FMI seria o emprestador dos países em déficit, com os recursos provenientes de suas reservas em ouro ou moedas de outros países membros e, se a moeda de um país se tornasse "escassa" no FMI, este poderia autorizar outros países a adotarem controles cambiais sobre importações e outras compras em conta-corrente do país que tivesse excedente naquela mesma moeda.

Nem todas essas diretrizes foram postas em prática. O FMI e o Banco Internacional para a Reconstrução e Desenvolvimento (BIRD) não exerceram seus poderes na ampla extensão em que formalmente lhes foi conferido pelo Acordo - atuar de forma determinante no controle da política monetária internacional ${ }^{80}$.

\footnotetext{
${ }^{80}$ Pela primeira vez fundava-se uma instituição monetária central de âmbito mundial e um conjunto universal de normas de conduta monetária era formulado. O que se criou foi o embrião de um banco central mundial. Bretton Woods estabelecia tanto o Fundo Monetário Internacional quanto o Banco Internacional para Reconstrução e Desenvolvimento, mas, como acreditava Keynes, o fundo era de fato um banco e o banco, um fundo. SOLOMON, Robert. O Sistema Monetário Internacional 1945-1976. Tradução de Nathanael C. Caixeiro. Rio de Janeiro: Zahar, 1979. p. 27.
} 
De fato, de 1945 até 1970, período em que vigorou a sistemática de Bretton Woods e do padrão dólar-ouro, com os demais países estabelecendo a paridade de suas moedas em relação ao dólar, pode-se dizer que o capitalismo passou por uma fase de prosperidade.

O sistema de Bretton Woods ofereceu previsibilidade às decisões capitalistas e, ao cabo, permitiu a obtenção dos resultados econômicos altamente favoráveis. Tratou-se, assim, de um arranjo monetário internacional que sob a liderança americana permitiu a reconstrução industrial da Europa e do Japão, a industrialização periférica e o desenvolvimento de economias nacionais autônomas, sem o qual dificilmente a fase dourada do capitalismo teria ocorrido ${ }^{81}$.

Tratava-se de uma nova ordem mundial apoiada sobre o imperialismo norteamericano. Os Estados Unidos assumiram a responsabilidade pela estabilização financeira global. Em completo desacordo com o que inicialmente havia sido proposto por Keynes, o padrão dólar-ouro de Bretton Woods consolidou os Estados Unidos como grande potência emissora da única moeda internacionalmente aceita, o que aprofundou as assimetrias no sistema monetário internacional.

A prosperidade do capitalismo nessa sistemática que consagrou os Estados Unidos $^{82}$ como o centro do mundo durou trinta anos e só foi abalada com a crise de seu balanço de pagamentos, agravada por acontecimentos que de alguma maneira fragilizaram esse país política e economicamente, tais como a Guerra da Coreia (1950 a 1953) e a Guerra do Vietnã (1959 a 1975).

\footnotetext{
${ }^{81}$ OLIVEIRA, Giuliano; MAIA, Geraldo; MARIANO Jefferson. O sistema de Bretton Woods e a dinâmica do sistema monetário internacional contemporâneo. Pesquisa \& Debate, São Paulo, v. 19, n. 2, p. 216, 2008.

${ }^{82}$ HUBERMAN, Leo. op. cit., p. 23. A indústria monopolista trouxe grandes lucros a seus donos. Superlucros. Mais dinheiro do que eles poderiam usar. Parece incrível, mas em certos casos os lucros foram tão grandes que os organizadores dos trustes não poderiam gastá-los todos, mesmo que tentassem. Não tentaram. Economizaram o dinheiro - e o mesmo fizeram com outros milhões de pequenos poupadores, que colocavam seu dinheiro em bancos, companhias de seguros, empresas de investimento etc. O resultado foi uma superacumulação de capital. Isso parece engraçado. Como é possível haver dinheiro demais? Não haveria outras formas para a utilização do capital? Certamente era preciso construir estradas, levantar hospitais; existiam favelas a derrubar, para construir em seu lugar casas decentes. Certamente havia mil e uma coisas para fazer com o dinheiro, não? Havia. As áreas rurais precisavam de melhores estradas, os trabalhadores de casas decentes e os pequenos negócios queriam expandir-se; mesmo assim, os economistas falam de capital "excedente". E não há dúvida disso - milhões de dólares (e francos, libras e marcos) estavam sendo exportados para outras áreas. Por quê? Porque o capital não pergunta: "O que é preciso fazer?" Nada disso. Pergunta: "Quanto posso conseguir pelo meu dinheiro?". A resposta a essa pergunta determina onde será investido o excedente.
} 


\subsection{O Colapso da Sistemática de Bretton Woods}

Em razão dos vultosos gastos bélicos mantidos pelos Estados Unidos em 1968, verificou-se a redução drástica das reservas de ouro do país, o que dificultou a observação da paridade dólar-ouro (pilar da sistemática de Bretton Woods). Em 1971, o então presidente Richard Nixon abandonou unilateralmente a conversibilidade em ouro do dólar afundando, enfim, o sistema monetário internacional que sustentava a economia mundial há três décadas.

Como a simples desvalorização do dólar poderia gerar uma fuga para o ouro, colocando em risco a condição do dólar de moeda internacional e, ao cabo, impondo a restrição de balanço de pagamentos à economia americana, esta opção era refutada pelo governo americano. A criação e proliferação do uso de uma moeda internacional, mediante a introdução dos direitos especiais de saque, teria o mesmo efeito. (...) A solução encontrada foi o abandono da convertibilidade em 1971, que deu suporte ao realinhamento do dólar logo depois ${ }^{83}$.

Os dois choques sucessivos nos preços mundiais do petróleo ocorridos na década de 1970 evidenciaram, para o restante dos países que acreditavam na manutenção do sistema, a impossibilidade de sustentar a conversibilidade do dólar em ouro o que ratificou a inviabilidade de manter o acordo de Bretton Woods.

O consequente endividamento a que se submeteram os países subdesenvolvidos buscando superar a crise econômica decorrente das sucessivas altas do preço do petróleo, a queda do mercado de ações nos Estados Unidos e a alta dívida pública interna, associada a uma alta contínua da inflação nos demais países desenvolvidos, levaram ao surgimento de um forte movimento contra o modelo de Estado Keynesiano com objetivo reduzir a sua intervenção na economia.

Neste sentido, o Pós-Bretton Woods, 'sistema' desregulado, assentado na 'diplomacia das armas' e na 'diplomacia do dólar', baseado na supremacia dos "processos de capitalização financeira" sobre os processos de renda, constituiu a expressão regulatória do sistema mundial nos últimos trinta anos, que pôs fim às tentativas de domesticação do capitalismo. Mais do que reorganizar o sistema de relações interestatais, criou as condições para a consolidação do poder americano, cada vez mais imperial, e impôs um retrocesso nas políticas de proteção social cujo ápice histórico foi o bem-estar do período anterior ${ }^{84}$.

\footnotetext{
${ }^{83}$ OLIVEIRA, Giuliano; MAIA, Geraldo; MARIANO Jefferson. op. cit., p. 209.

${ }^{84}$ MASSONETTO, Luís Fernando. op. cit., p. 41.
} 
Com a adoção de taxas de câmbio mais flexíveis, o novo padrão dólar-flexível adquiriu uma natureza exclusivamente fiduciária ${ }^{85}$. O dólar deixou de vincular-se a uma mercadoria real (ou seja, ao ouro) e a ideia de uma economia globalmente liberalizada voltou à cena.

(...) o padrão dólar flexível amplificou a assimetria e a hierarquia do sistema monetário internacional, estabelecendo um padrão sistêmico de riqueza subjugado ao mundo das finanças e cada vez menos sintonizado com o plano da produção e do trabalho, especialmente a partir do sepultamento definitivo do Sistema de Bretton Woods ocorrido quando da regeneração do dólar mediante o choque monetário de $1979^{86}$.

Com efeito, o projeto econômico-político de alçar ao segundo plano a produção e o trabalho em detrimento de um padrão sistêmico de riqueza subjugado ao mundo das finanças foi liderado especialmente pelos Estados Unidos. Essa transição está bem pontuada por José Eduardo Faria ${ }^{87}$ que assim resume o sucesso de um Estado voltado à resolução dos dilemas econômicos e sociais e o início de sua decadência como fruto dos desequilíbrios oriundos da nova ordem internacional:

Contrapondo deste modo taxas expressivas de crescimento econômico e programas de bem-estar às incertezas, crises, dilemas e guerras dos conturbados anos 20 e dos sombrios anos 30 , quando as instituições democrático-representativas liberais sofreram a concorrência do sucesso temporário das diferentes formas de fascismo, e "retribuindo" proporcionalmente mais ao trabalho do que ao capital com sua pauta distributiva, as políticas de inspiração Keynesiana criaram um círculo virtuoso entre aumento dos salários reais, elevação da produtividade e redução das distâncias sociais. Foi assim que conseguiram acabar criando, especialmente entre as décadas de 50 e 60, um clima político social de muita confiança nesta forma de regulação, controle, gestão, direção e planejamento estatais. Graças a elas, o estado intervencionista por um lado dispunha de condições para amenizar tensões, neutralizar pressões e bloquear eventuais ameaças à legitimidade institucional; e, por outro, contava com a flexibilidade decisória necessária para estimular, promover, disciplinar, regular e planejar o crescimento, bem como para enfrentar os riscos de instabilidade conjuntural ou estrutural, podendo desta maneira preservar o processo econômico de problemas disfuncionais. A partir dos choques do petróleo, da instabilidade monetária e da crise financeira dos anos 70, no entanto, tanto essas

\footnotetext{
${ }^{85}$ Para as grandes economias como a dos Estados Unidos e Japão, essa é uma condição suportável. As economias relativamente grandes e relativamente fechadas são capazes de perseguir os objetivos internos necessários num mundo polanyiano sem sofrer dificuldades intoleráveis resultantes de oscilações cambiais. Assim, há boas razões para pensar que as moedas desses países continuarão a flutuar umas em relação às outras. Para a maioria das economias menores e mais abertas, porém, os custos da flutuação são difíceis de suportar. EICHENGREEN, Barry. op. cit., p. 253.

${ }^{86}$ OLIVEIRA, Giuliano; MAIA, Geraldo; MARIANO Jefferson. op. cit., p. 211.

${ }^{87}$ FARIA, José Eduardo Campos de Oliveira. O direito na economia globalizada. São Paulo: Malheiros Ed., 2007. p. 114.
} 
ameaças quanto esses riscos passaram a ocorrer em ritmo cada vez mais intenso. Como conseqüência, os ciclos de prosperidade e estagnação se tornaram cada vez mais curtos, solapando velozmente as bases fiscais de financiamento dos gastos sociais.

De fato, o crescente conflito entre as políticas econômica e social que teve como resultado o forte abalo nas estruturas do Estado-Providência na década de 1970, levou a sérios questionamentos no que tange a sua eficiência e acabou abrindo espaço para que outro modelo, diametralmente oposto, fosse colocado em prática.

Offe, ao considerar que o Welfare State Keynesiano é uma vítima de seu próprio sucesso, explica as razões de seu ocaso, trinta anos depois:

“(...) o setor público não-produtivo tornou-se uma carga intolerável para o setor privado, levando a uma carência crônica de capital de investimentos; a ética do trabalho está em processo de solapamento e a classe média independente está sufocada, economicamente, pelas taxações elevadas e pela inflação. (...) Isto nos levaria a concluir que a intervenção do Estado só é efetiva na medida em que ela ocorre de "surpresa" e em caráter excepcional, ao invés de ser assunto de rotina (...). Assim, por razões que têm a ver tanto com seus efeitos econômicos externos como com os paradoxos do seu modo de funcionamento interno, o WSK carece ter exaurido, em grande parte, seu potencial e sua viabilidade." ${ }^{, 88}$

Para Offe, portanto, o agigantamento do Estado criou problemas insolúveis, tanto em razão do aumento exponencial dos gastos públicos que massacravam as classes médias com impostos cada vez mais altos, quanto em razão da própria ineficiência desse Estado que interveio em todos os setores sociais, assumindo mais problemas do que seria efetivamente capaz de resolver.

Embora, de acordo com as análises feitas para os fins deste trabalho, não se entenda que modelo de Estado Keynesiano esteja esgotado, ao contrário provavelmente tenha sido a melhor proposta de conciliação entre Estado e mercado até hoje vista, não há como negar o seu desgaste em decorrência dos vícios dos governos que o implantaram.

O abuso de seus mecanismos, o descontrole com os gastos públicos, a corrupção e a mudança dos interesses dominantes em relação ao que seria o modelo ideal de Estado, combinados com os fatos econômicos incontroláveis, como a crise do petróleo, acabaram por esgotá-lo.

\footnotetext{
${ }^{88}$ OFFE, Claus. op. cit., p. 380-381.
} 


\subsection{O consenso de Washington e o Estado Neoliberal}

A concepção de Estado Neoliberal surgiu atrelada ao discurso da teoria econômica chamada "neoclássica", a qual propugna pela não intervenção do Estado. Atuando de forma racional, os agentes de mercado levariam a economia a um equilíbrio natural. Notase aí, claramente, a repetição do velho discurso inaugurado em 1776, e a volta do conflito entre Estado e mercado, o que pode ser considerado, com base no exposto a respeito da desestruturação das relações sociais do século XIX, um verdadeiro retrocesso ${ }^{89}$.

O liberalismo clássico, vale destacar, somente difere desse "novo liberalismo" em razão de seus algozes: enquanto o velho liberalismo pregava contra o mercantilismo, as corporações de ofícios e os privilégios dos mestres, o neoliberalismo vai contra o Keynesianismo e tudo o que essa ideologia representa, em benefício e exaltação do livremercado.

Os chamados neoliberais liderados por economistas adeptos do laissez-faire, tais como Milton Friedman ${ }^{90}$ e Friedrich Hayek, em larga medida acusaram a política do Welfare State como a responsável pela crise financeira, denunciaram a corrosiva inflação que assolava as economias de então como o resultado desastroso de uma política monetária mal-conduzida, na qual o excesso de emissão de papel-moeda influenciaria diretamente as altas taxas. A verdade é que a priorização do emprego em detrimento da busca da

\footnotetext{
${ }^{89}$ YAZBEK, Otavio. op. cit., p. 14, ao discorrer sobre o "sistema de mercado" introduzido pelos neoclássicos, em que a figura da "mão invisível" foi, aos poucos, substituída pelo "equilíbrio de mercado", embora defenda a utilidade científica desse mecanismo quando se trata da previsão de comportamentos e da explicação de fenômenos econômicos, faz ressalvas: "Tanto a questão do equilíbrio quanto o princípio da racionalidade ganharam, com o tempo, uma dimensão maior do que a de meros postulados de modelo econômico, começando a ganhar foro de tentativa de explicação da racionalidade. Esta pretensão vem, há muito, sendo apontada, de forma crítica, por economistas filiados à própria tradição neoclássica como Knight e Akerlof, para referir autores de gerações distintas. (...) Pior, a adoção daquelas posturas equivocadas tende a levar a conclusões ou a decisões falhas, senão desastrosas especialmente em matéria de políticas públicas."

${ }^{90}$ Esse autor, em diversas de suas obras, reafirmou suas convicções liberais e a certeza de que as crises, especialmente a partir das décadas de 60/70 do século XX, têm como causa o intervencionismo estatal. "A maior parte dos empreendimentos realizados pelo governo nas últimas décadas não alcançou os objetivos previstos. Os Estados Unidos continuaram a progredir; seus cidadãos estão mais bem alimentados, mais bem vestidos, mais bem instalados e dispõem de melhores transportes; as distinções sociais e de classe diminuíram; os grupos minoritários estão em situação menos desvantajosa; a cultura popular desenvolveuse. Tudo isso foi o resultado da iniciativa e do esforço de indivíduos cooperando através do mercado livre. As medidas governamentais prejudicaram em vez de favorecer tal desenvolvimento. Fomos capazes de suportar e superar tais medidas devido à extraordinária fecundidade do mercado. A mão invisível fez muito mais pelo progresso do que pelo retrocesso." FRIEDMAN, Milton. Capitalismo e liberdade. Tradução de Luciana Carli. São Paulo: Artenova, 1977. p. 170.
} 
estabilidade da moeda era tida como má-condução da política monetária pelos governos, representados, nesse campo, pelos Bancos Centrais, por ser inflacionista.

O modelo de Estado agigantado e dispendioso, que "massacraria a iniciativa privada com elevados impostos", seria o culpado pela queda da produção e do aumento da inflação. A solução que se propunha para o fim da crise seria a redução gradativa do poder do Estado, com a diminuição generalizada de tributos, a privatização das empresas estatais e o fim da possibilidade de o Estado regular os preços das mercadorias e serviços ${ }^{91}$.

Assim, o liberalismo econômico voltou à pauta, sob a alcunha de "neoliberalismo" em meados da década de $1970^{92}$. A sua evolução vem provocando, desde então, transformações estruturais em todos os campos da vida humana.

Com o objetivo de desvendar a nova realidade mundial, a qual, partindo das mesmas premissas do liberalismo clássico, propaga aos quatro ventos a ideia de que a economia mundial estaria equilibrada tão logo o Estado deixasse de nela interferir, serão objeto de análise, a seguir, alguns aspectos do neoliberalismo.

As relações comerciais entre os países após o advento da "globalização financeira" ${ }^{, 93}$ transformaram-se totalmente. Trata-se de um mundo livre de barreiras legais ou físicas, no qual circulam livremente bens, serviços, capitais e tecnologia.

Todavia, cumpre destacar que essa "livre" circulação não tem sido uma pista de mão dupla, dado que, conforme destaca José Eduardo Faria ${ }^{94}$, existem fortes pressões por parte dos países desenvolvidos para que os países em desenvolvimento procedam à completa liberalização de seu comércio exterior (globalização irrestrita) enquanto aplicam

\footnotetext{
${ }^{91}$ GRAU, Eros Roberto. op. cit., p. 48. "O fato é que a apologia ideológica do mercado é produzida em função exclusivamente do interesse do investidor, que é o de baixar custos que oneram a empresa (os salários, os tributos e as cargas sociais)."

${ }^{92}$ Em 1974, Pinochet percebeu que eram necessárias medidas radicais para conter a inflação. Nesse sentido, ele decidiu adotar um programa de reforma drástica - um programa que havia sido criado por um grupo de economistas que passaram a ser chamados de "Chicago Boys" porque quase todos tinham feito trabalhos de pós-graduação na Universidade de Chicago. Em 1975, nomeou alguns desses economistas para o seu gabinete. Eles cortaram de forma acentuada as despesas do governo e o emprego, reprivatizaram empresas que tinham sido encampadas pelo governo Allende e eliminaram os controles de preços, salários, importações e exportações. Essas alterações permitiram uma drástica redução da criação de moeda. FRIEDMAN, Milton. $O$ poder e o dinheiro: episódios da história monetária. Tradução de Maria da Graça Pinhão. Portugal: Publicações Europa América, 1992. p. 218.

${ }^{93}$ Para GRAU, Eros Roberto. op. cit., p. 55, a globalização é um fato histórico e o neoliberalismo, uma ideologia. De todo modo, embora essa afirmação esteja repleta de sentido, a questão principal é que a ideologia aproveitou-se do fato histórico para subsumi-lo a seus interesses de forma que ambos perfazem, juntos, essa nova etapa da história. Nesse sentido, NUNES, António José Avelãs (Neoliberalismo e direitos humanos, cit., p. 64) entende que o Neoliberalismo é a matriz ideológica da globalização.

${ }^{94}$ FARIA, José Eduardo Campos de Oliveira. op. cit., p. 143.
} 
barreiras e sanções para impor limites em suas próprias fronteiras, exercendo uma globalização seletiva.

Além disso, conforme destaca José Avelãs Nunes ${ }^{95}$, a liberdade da globalização não se estende à livre circulação de trabalhadores, pois são criadas, por parte dos países desenvolvidos, barreiras voltadas a impedir o que se poderia chamar de "nova invasão dos bárbaros" (estudos da Organização das Nações Unidas indicam que cerca de 160 milhões de pessoas se deslocarão do Sul para o Norte até 2025).

Outro reflexo da globalização está representado pela presença maciça das multinacionais. Produto do desenvolvimento das relações comerciais em proporções continentais, as empresas de proporções gigantescas têm patrimônio e poderio maior do que o de muitas nações. Tais empresas passaram a estabelecer-se em todas as partes do mundo, mantendo como centro de tecnologia e inteligência a sua matriz sediada nos países desenvolvidos.

A partir de então, passaram a influenciar decisões internas dos países, patrocinar projetos que lhes trazem benefícios específicos, exercer pressões para mudar normas e procedimentos nacionalmente estabelecidos, bem como passaram a transformar a identidade cultural dos países que as sediam, disseminando os hábitos e costumes ${ }^{96}$, padronizando os "desejos de consumo" para, assim, atingir com seus produtos uma sempre maior escala de fiéis compradores (“colonização cultural”).

A chamada "flexibilização de relações trabalhistas", ou mesmo a privatização da previdência e das demais instituições originalmente públicas, voltadas a proporcionar e a garantir o bem-estar coletivo, direitos conquistados à custa de muitas lutas, são, também, consequências melancólicas de governos neoliberais comprometidos com o "equilíbrio orçamentário" a qualquer custo.

Como consequência, verifica-se a redução do poder dos sindicatos representantes de classes, dado que suas exigências encareceriam o processo de produção e o custo dos empregados, em detrimento da possibilidade de angariar novas perspectivas de investimento.

\footnotetext{
${ }^{95}$ NUNES, António José Avelãs. op. cit., p. 72.

96، A globalização é também um fenômeno cultural e ideológico, marcado pela afirmação decisiva dos aparelhos ideológicos como instrumento de domínio por parte dos produtores da ideologia dominante, a ideologia do pensamento único, a ideologia das massificações dos padrões de consumo, dos padrões de felicidade, a ideologia que impõe a sociedade de consumo como paradigma de desenvolvimento, a ideologia que pretende anular as culturas e as identidades nacionais." NUNES, António José Avelãs. op. cit., p. 73 .
} 
Os direitos sociais, há muito consagrados, convertidos em serviços públicos são outra transformação trazida pelo ideário neoliberal. Num contexto em que as ações do Estado são pautadas exclusivamente pelos interesses do mercado, o cidadão fica reduzido a mero cliente/consumidor" de "serviços" delegados e fiscalizados por esse Estado mínimo, o qual, por sua vez, fica de mãos atadas para perseguir objetivos mais nobres e, por que não dizer, necessários à construção de uma sociedade justa.

Com efeito, o primeiro governo democrático a se inspirar nos princípios do neoliberalismo foi o de Margareth Thatcher na Inglaterra, em 1980, seguido pelo de Ronald Reagan nos Estados Unidos (1981 a 1989). Durante esses mandatos, considerados significativos por incorporarem rigorosamente os "novos" ideais liberais, foram aprovadas leis que revogavam privilégios concedidos aos sindicatos, privatização de empresas estatais e redução de direitos trabalhistas.

Essa nova ideologia disseminou-se para o restante do globo por meio das diretrizes do chamado "Consenso de Washington" " Esse movimento, capitaneado pelo Fundo Monetário Internacional com a chancela dos Estados Unidos, visou disciplinar a condução das atividades dos governos por todo o mundo, a fim de "equilibrar suas contas" e recuperá-los das crises.

\footnotetext{
97، Com a reforma do Estado, criaram-se duas áreas distintas de atuação para o Poder Público: de um lado a Administração Pública centralizada, que formula e planeja as políticas públicas. De outro, os órgãos reguladores (as "agências"), que regulam e fiscalizam a prestação dos serviços públicos. Isto contraria o próprio fundamento das políticas públicas, que é a necessidade de concretização de direitos por meio de prestações positivas do Estado, ou seja, por meio de serviços públicos. Política pública e serviço público estão interligados, não podem ser separados, sob pena de esvaziarmos o seu significado. Sintomática do espírito da Reforma do Estado, ainda, foi a substituição no texto constitucional dos beneficiários dos serviços públicos: a coletividade foi substituída pelo usuário (...). O cidadão, com a reforma gerencial, é apenas entendido como cliente, como consumidor.” BERCOVICI, Gilberto. Concepção material de serviço público e Estado brasileiro. In: Serviços públicos e direito tributário. São Paulo: Quartier Latin, 2005. p. 64.

${ }^{98}$ Diretrizes fixadas pelo Consenso de Washington:

1. disciplina fiscal, através da qual o Estado deve limitar seus gastos à arrecadação, eliminando o déficit público;

2. focalização dos gastos públicos em educação, saúde e infra-estrutura;

3. reforma tributária que amplie a base sobre a qual incide a carga tributário, com maior peso nos impostos indiretos e menor progressividade nos impostos diretos;

4. liberalização financeira, com o fim de restrições que impeçam instituições financeiras internacionais de atuar em igualdade com as nacionais e o afastamento do Estado do setor;

5. taxa de câmbio competitiva;

6. liberalização do comércio exterior, com redução de alíquotas de importação e estímulos à exportação, visando impulsionar a globalização da economia;

7. eliminação de restrições ao capital externo, permitindo investimento direto estrangeiro;

8. privatização, com a venda de empresas estatais;

9. desregulação, com redução da legislação de controle do processo econômico e das relações trabalhistas;

10. propriedade intelectual.
} 
Essencialmente, previa, num breve compilado de dez "mandamentos", a consolidação dos principais ideais neoliberais, como: a diminuição da atuação do Estado no domínio econômico, tanto no que diz respeito a sua intervenção como "empresário" e fomentador da economia, quanto à regulação das atividades do mercado, restrição dos gastos públicos, reforma tributária e revisão dos direitos trabalhistas.

A partir disso, tem-se que a competição internacional do mercado financeiro global passa a fixar objetivamente os padrões fiscais e monetários que consideraria "desejáveis". A estabilidade monetária tornou-se objetivo principal a ser perseguido, dado que passou a ser atributo de competitividade, exigência mínima para obtenção de crédito no mercado internacional $^{99}$. Para a obtenção de financiamento externo, a condição mínima a ser cumprida seria a observância das regras do Consenso. Como consequência, países com dificuldades financeiras e sem outra opção, foram conduzidos a adotar essa nova ideologia.

Com efeito, esse movimento de diminuição da atuação estatal pôde ser identificado na prática, por meio da rigorosa observância às diretrizes acima, em que se verificou o desmonte da estrutura do Estado, com o sucateamento e abandono do desenvolvimento estatal em detrimento do desenvolvimento e agigantamento das instituições dominadas pelos interesses privados - as multinacionais.

Os preceitos do Consenso, embora tenham sido formulados há menos de duas décadas, não há dúvida, estão ultrapassados. O resgate do laissez-faire do século XIX, de redução do Estado à manutenção da 'lei e da ordem', proteção dos contratos e da propriedade privada, com mercados pulverizados e mão de obra como sinônimo de mercadoria, representam um retrocesso de, no mínimo, duzentos anos.

Atualmente, quer-se acreditar que os países que alcançaram determinado patamar evolutivo não se encaixam nesse modelo, embora praticamente todos tenham adotado essa proposta $^{100}$. De todo modo, os efeitos da adoção de tal política são sensivelmente maléficos

\footnotetext{
${ }^{99}$ Interessante notar como algumas soluções econômicas propostas para o alcance ou manutenção do equilíbrio e da estabilidade econômica ganham força de lei, ou, mais ainda, força de dogma sagrado irretocável. Foi assim com a sustentação - a qualquer preço - do "padrão-ouro", pilar do liberalismo clássico, e assim é com a "estabilidade da moeda" que se tornou, como política de governo, mote usado inclusive em campanhas eleitorais e, como não dizer: o objetivo único a ser alcançado pelos Bancos Centrais em detrimento de qualquer outro objetivo seja ele o pleno emprego, seja o aumento da produtividade, seja o crescimento do país.

${ }^{100}$ Encolher o Estado tornou-se uma palavra de ordem respeitável, mesmo entre antigos defensores da intervenção estatal. Enquanto a onda cresceu, pouco esforço se fez para distinguir as várias funções públicas e o seu significado social. A crise financeira do Estado, experiência comum a grande número de países, na década de 1980 e em parte na de 1990, ajudou a embolar as questões: afinal o mais urgente era arrumar as contas, depois de um desajuste prolongado. Estava em curso, porém, muito mais um acerto
} 
à estrutura social. Nota-se a desmontagem do "Estado-Providência" em prejuízo da maioria da população.

Diferentemente do que ocorria no sistema de Bretton Woods, em que os Estados eram dotados de liberdade para flexibilizar variáveis internas para proteger suas economias, administrando o câmbio, o orçamento, e a oferta monetária para manter o emprego, atualmente inflação e resultado fiscal não são mais problemas exclusivamente internos de cada país, mas variáveis consideradas relevantes no momento da obtenção de crédito e celebração de contratos internacionais.

Comprovando o que vem sendo dito neste trabalho a respeito do controle dos mercados pelo Estado, em 2008, eclodiu uma grave crise financeira de proporções globais $^{101}$, provavelmente em razão das rédeas soltas concedidas ao mercado autorregulável e sem fronteiras.

As autoridades americanas e europeias não viram - ou não quiseram ver - a grande bolha especulativa que tomou conta de seus sistemas financeiros e alastrou-se pelo restante do mundo. A origem da crise ocorreu nos Estados Unidos: os bancos privados repassaram a seus clientes instrumentos financeiros de alto risco, vendidos como se fossem seguros.

Como só os bancos privados conheciam o risco dos papéis, seria essencial um regulador não só para impedir que o cliente fosse enganado, como também para limitar o

fiscal. Metamorfose dos mercados e reforma do estado são aspectos de um mesmo processo mundial de reconstrução do capitalismo. A mudança nos mercados pode ter parecido, de início, apenas uma ampla reestruturação econômica. Essa reestruturação estaria associada à inovação tecnológica e à reorganização empresarial, e seria administrada, até certo ponto, segundo os padrões do Consenso de Washington. Mas é muito mais que isso. Cientistas políticos e economistas têm discutido os efeitos da globalização na eficácia das políticas nacionais. KUNTZ, Rolf. op. cit., p. 372-373.

${ }^{101}$ A Crise do subprime originou-se em 2006, com a quebra de instituições de crédito dos Estados Unidos, que concediam empréstimos hipotecários de alto risco (subprime mortgage) sem realizar a devida avaliação da capacidade de pagamento de seus clientes. Os empréstimos subprime embutem maior risco, devido à maior inadimplência e, por esse motivo, pagam juros mais altos, o que os tornou mais atraentes para gestores de fundos e bancos em busca de retornos maiores. O que ocorreu foi que os gestores, ao comprarem tais títulos "podres" das instituições que fizeram o primeiro empréstimo, possibilitavam que um novo montante de dinheiro fosse novamente emprestado, antes que o primeiro empréstimo fosse pago. Com a crise de confiança em relação à capacidade de adimplemento dos credores hipotecários, houve uma retração na oferta de crédito. Verificou-se, a partir de então, um efeito em cadeia em que vários bancos foram levados à situação de insolvência, repercutindo fortemente sobre as bolsas de valores de todo o mundo. Em agosto e setembro de 2008, a crise chegou ao seu auge com a estatização dos gigantes do mercado de empréstimos pessoais e hipotecas - a Federal National Mortgage Association (FNMA) e a Federal Home Loan Mortgage Corporation (FHLMC), para que sua falência não fosse decretada. Logo em seguida, o tradicional banco de investimentos, Lehman Brothers, um dos pilares financeiros de Wall Street, abriu concordata e a corretora Merrill Lynch (uma das maiores e mais tradicionais corretoras do mundo) foi vendida ao Bank of America. No mesmo dia, as ações da American International Group Inc. (AIG), a maior empresa seguradora dos Estados Unidos, caíram 60\%, na abertura do mercado. (Fonte: Jornal Valor Econômico, São Paulo, 12-15 set. 2008). 
efeito em cadeia gerado pela transmissão de riscos que percorre os mesmos caminhos dos canais globais de intermediação financeira.

Certamente, a assunção de tamanhos riscos não calculados pelas instituições financeiras, inclusive por aquelas tidas como sólidas, experientes e até mesmo "inquebráveis", são consequência da ineficiência do controle regulatório e da excessiva liberdade concedida aos agentes econômicos, dado o pressuposto de que teriam a capacidade de eficientemente se "autorregular".

Constata-se, portanto, que os fenômenos cíclicos da economia tem o condão modificar as ideias dominantes a respeito da solução ideal no que tange ao Estado e o adequado uso das políticas econômicas. Em tempos de recessão, o caminho é a política fiscal que deve atuar de forma expansionista, ou seja, o Estado-herói intervém na economia, socorre todos com crédito fácil e barato, evitando o pior. E, aí, no momento seguinte, quando a inflação começa a despontar, volta-se à ortodoxia em que o Estadovilão deve limitar sua atuação ao mínimo possível, apenas para garantir os limites do contrato social.

Em vista do fato de esse acontecimento ser muito recente para que se possa fazer uma precisa análise sobre suas consequências (para o bem e para o mal), o ponto principal a ser observado, desde agora, é que o Estado ${ }^{102}$, mais uma vez ele, foi chamado em socorro do mercado e suas poderosas instituições financeiras: muitas delas "viraram pó" do dia para a noite, confirmando a proposição de que o Estado não é importante, até que precisem dele.

Por fim, no que tange a absorção das convicções neoliberais pelos países menos desenvolvidos (nesse novo contexto nomeados apelidados de "emergentes") altamente dependentes do capital externo, houve a exacerbação do exercício de uma política essencialmente monetarista pelos governos, com elevação da taxa de juros e o amplo

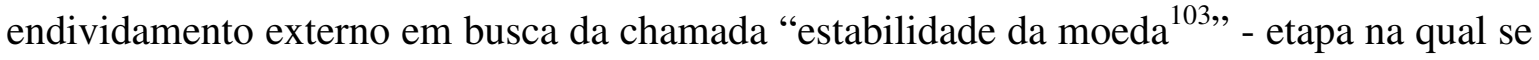

\footnotetext{
${ }^{102}$ Em entrevista à revista Veja, São Paulo, ed. 2130, ano 42, n. 37, 16 set. 2009, Moisés Naím, ex-diretor do Banco Mundial fez o seguinte comentário sobre a crise: "A grande surpresa negativa que tivemos foi a debilidade da Europa onde uma dezena de governos caiu desde o início da crise. Já a China e o Brasil se saíram melhor do que se esperava. De modo gral, vimos um crescimento da ação do estado na economia em todo o mundo. Foi a saída possível para que se evitasse um mal maior. Passada essa fase, os governos, sem dúvida, terão um peso maior nas economias relativamente ao que se viu nas últimas duas décadas".

103،A eficácia dos controles adotados pelos bancos centrais evoluiu ao longo do tempo com o desenvolvimento institucional de cada país. No período recente, as transformações financeiras intensas, em particular, a liberalização dos controles sobre a atividade financeira dos bancos e das instituições financeiras não bancárias, a securitização e a proliferação dos instrumentos derivativos de crédito
} 
verifica claramente o abandono do exercício, pelos Bancos Centrais, de política monetária voltada para alcançar os objetivos dos planos de governo traçados com vista a fomentar o desenvolvimento econômico.

Em diversos países classificados como "em desenvolvimento", como é o caso do Brasil, o Banco Central ficou reduzido a ser perseguidor de "metas inflacionárias"104 e determinado unicamente a assegurar a estabilidade da moeda. Como bem esclarece José Eduardo Faria ${ }^{105}$ ao mencionar exemplos que identificam as mudanças estruturais mencionadas:

Por fim, um último exemplo é dado pelos governos latino-americanos, que precisam de capitais externos para estabilizar suas moedas, sendo obrigados a desregulamentar seus mercados e a oferecer altas taxas de juros reais para atraí-los. Quanto mais agem nesta linha, mais têm de regular o controle da entrada de recursos de curto prazo, principalmente quando os capitais externos, atraídos pelas possibilidades de elevados ganhos reais em face dos altos juros oferecidos, ingressam muito velozmente e em quantidades superiores à solução da equação financeira interna.

Certamente que o caso dos países latino-americanos cooptados pelos ideais do neoliberalismo não apresenta novidade, trata-se de um capítulo mais recente da história de dominação imperialista que se prolonga desde o "descobrimento" desses países, tratandose de episódio com efeitos desastrosos no que tange ao desmonte da estrutura estatal.

complicaram sobremaneira a tarefa dos bancos centrais no que se refere à formulação e à execução da política monetária. Ao mesmo tempo, com a globalização financeira e a chamada ditadura dos mercados, a estabilidade de preços domésticos tornou-se o objetivo primordial dos bancos centrais, seja nos países industrializados, seja nos países em desenvolvimento. Porém, esse objetivo opõe-se à função essencial dos bancos centrais, que é a de atuar como prestamista de última instância para impedir a eclosão de crise de confiança no sistema bancário." FREITAS, Maria Cristina Penido de. Racionalidade da regulamentação e supervisão bancária. SOBREIRA, Rogério (Org.). Regulação financeira e bancária. São Paulo: Atlas, 2005. p. 32.

${ }^{104}$ Friedman defendeu a independência dos bancos centrais em relação ao estado, a fim de que pudessem formular suas políticas monetárias sem a influência dos governos, com objetivo único de manter a estabilidade monetária com base na perseguição de metas de inflação. "Na atual situação, tal norma cortaria drasticamente o poder discricionário das autoridades monetárias; ma ainda deixaria um volume indesejável de liberdade nas mãos do Federal Reserve e das autoridades do Tesouro com respeito a como alcançar a taxa estabelecida do crescimento no estoque do dinheiro e a supervisão bancária, entre outras coisas. Reformas bancárias fiscais adicionais, que descrevi em detalhes em outra obra, seriam não só necessárias como convenientes. Teriam o efeito de eliminar a intervenção governamental nos empréstimos e nos investimentos e de converter as operações governamentais de financiamento, de fonte perpétua de instabilidade e incerteza em atividade regular e previsível. Mas, embora importantes, estas reformas adicionais são menos básicas do que a adoção de uma norma que limite a liberdade das autoridades monetárias no que concerne ao estoque de dinheiro.” FRIEDMAN, Milton. Capitalismo e liberdade, cit., p. 54.

${ }^{105}$ FARIA, José Eduardo Campos de Oliveira. op. cit., p. 144. 


\subsection{Constatações e Perspectivas}

O modelo de Estado neoliberal vem sendo repensado e não é mais a "quase unanimidade" que costumava ser quando surgiu em $1970^{106}$. A globalização, como fato histórico, permanece caminhando a largos passos em direção ao futuro. A nova ideologia que a acompanhará e definirá seus rumos ainda não está com seus contornos totalmente definidos.

Embora a globalização tenha derrubado fronteiras e uniformizado padrões de comportamento ao redor do mundo, isso não muda o fato de que a ordem econômica ${ }^{107}$ é produto das relações de poder estabelecidas ao longo da história de cada um dos países e de suas peculiaridades políticas, institucionais, culturais, históricas e regionais. Como cada nação possui características próprias, também a dinâmica da condução da economia deverá ser específicas de acordo com a realidade de cada uma delas. A imposição unilateral de um modelo padronizado embora tenha tido grande aceitação não poderá lograr sucesso ao longo do tempo, é o que se espera da experiência neoliberal.

Ademais, a presença do Estado na economia é fundamental para o desenvolvimento de acordo com os interesses da sociedade, observados os direitos dos cidadãos considerados individualmente. As ameaças a sua soberania e ao seu poder de regulamentar os mercados devem ser combatidas, sob pena de se verificar o desmonte das relações sociais e produtivas, assim como reiteradamente tem-se visto das experiências analisadas.

Paulo Bonavides ${ }^{108}$ assevera que o Estado Moderno possui três distintas fases de evolução: o Estado Liberal (constitucional da separação de poderes), o qual em seu constante processo de evolução, ao buscar a conferir liberdade ao indivíduo, desembocou no Estado Social (constitucional dos direitos fundamentas), o qual, por sua vez, trouxe às constituições os direitos sociais. A partir de então, chega-se a uma encruzilhada, na qual o Estado tem duas opções, voltar ao passado ou avançar para o futuro (essa seria a sua terceira fase):

\footnotetext{
${ }^{106}$ Certamente que a crise econômica verificada em 2008 proporcionará, mais e mais, esse tipo de reflexão sobre o afastamento do estado da economia e sobre os frágeis pilares de sustentação do Estado neoliberal.

${ }^{107}$ Segundo Eros Grau, ordem econômica pode ser definida como “(...) conjunto de normas que define, institucionalmente, um determinado modo de produção econômica. Assim, ordem econômica, parcela da ordem jurídica (mundo do dever-ser), não é senão o conjunto de normas que institucionaliza uma determinada ordem econômica (mundo do ser)". GRAU, Eros Roberto. op. cit., p. 72.

${ }^{108}$ BONAVIDES, Paulo. op. cit., p. 41.
} 
Se recuar, cai na armadilha neoliberal e globalizadora que afeta mortalmente o Estado e a soberania, o que se acha prestes a acontecer com alguns Estados da periferia; se avançar, faz a opção certa: elege o caminho da Democracia participativa, e busca, com determinação, inserir na ordem constitucional as novas franquias que o Homem conquistou ou está em via de conquistar, compendiadas em direitos fundamentais de diversas gerações ou dimensões já reconhecidas e proclamadas pelo Constitucionalismo de nosso tempo.

A democracia participativa de Bonavides pode ser o caminho ideal por representar a evolução do Estado-Providência adaptada à nova realidade global. Ele defende que a democracia deve ser alçada à categoria de princípio jurídico, para que se atinja o patamar de Estado da terceira geração, que representa o povo com o controle supremo sobre o governo e as instituições ${ }^{109}$.

Para que essa nova realidade social seja alcançada a todos deve ser dada igual oportunidade à educação, à cultura, à qualificação profissional, bem como ao livre aceso do exercício das profissões. O povo, para consolidar uma verdadeira democracia participativa, deve estar habilitado a exercer controle sobre o governo e as instituições e em seu próprio benefício. Somente o Estado pode alçar o povo a tal patamar evolutivo, por meio de investimentos voltados a seu desenvolvimento. Isso porque o Estado não tem direitos, somente tem deveres a cumprir perante a sociedade e foi construído juridicamente para organizar as relações sociais e proporcionar bem-estar àqueles que são sujeitos de direito.

Os Bancos Centrais na qualidade de órgãos estatais estão imbuídos dos mesmos deveres estatais, observado o seu âmbito de atuação. O povo, uma vez preparado para exigir do Estado as condições adequadas de vida digna, também estará pronto para exigir a prestação de contas por parte dessa instituição de modo a garantir que ela atue de acordo com o interesse coletivo.

Nada é certo quanto ao futuro e quanto ao novo tipo de Estado que predominará na próxima era em cada um dos países do globo, todavia é possível identificar como avanço considerável o fato de que muitos já admitem as consequências nefastas do neoliberalismo para a sociedade.

\footnotetext{
${ }^{109}$ BONAVIDES, Paulo. op. cit., p. 517, destaca que, para a concretização dessa proposta é necessária a observância de dois componentes, um político e o outro jurídico: "Componente político é o controle final e supremo do povo em todas as instâncias de exercício do poder, componente jurídico é o princípio democrático erigido à categoria de direito fundamental - hoje na doutrina, amanhã na prática. Em suma, o terceiro Estado de Direito outra coisa não significa senão o Estado social da democracia direta, em que a democracia se concebe, ao mesmo passo, como um direito fundamental da quarta geração."
} 


\title{
CAPÍtUlo II. EXECUÇÃo DAS POLÍticAS MONETÁRIA E CREDITÍCIA. O PAPEL DOS BANCOS CENTRAIS
}

\begin{abstract}
The outstanding faults of the economic society in which we live are its failure to provide for full employment and its arbitrary and inequitable distribution of wealth and incomes. (KEYNES, John Maynard. The General Theory of Employment, Interest and Money.)
\end{abstract}

\subsection{Introdução}

Por meio do exame de fatos históricos, no capítulo anterior procurou-se evidenciar que o modelo de Estado intervencionista verifica-se como o mais apropriado para cumprir os objetivos necessários ao desenvolvimento da sociedade. O modo de produção capitalista que emergiu a partir do Século XIX e consolidou-se como o regime-base da economia da sociedade ocidental desde então, não se sustentaria, assim como não se sustentou, exclusivamente por meio das forças do "livre mercado autorregulável".

O papel do Estado consiste em fomentar a atividade produtiva e a criação empregos para possibilitar a distribuição de renda e o bem-estar social, pois isso garante a preservação das relações sociais e, por conseguinte, da vida em sociedade.

Analisou-se no capítulo anterior, de forma abrangente quanto à interação conturbada e necessária entre os campos político e econômico - que nada mais são do que expressões das interações sociais. Neste contexto, deve-se estudar, de forma mais circunscrita, os Bancos Centrais, os quais congregam (ou ao menos deveriam) atribuições políticas e econômicas como talvez nenhum outro órgão estatal o faz.

O Banco Central, por ser parte integrante do Estado, tem como dever principal executar a política monetária orientada a corroborar os objetivos desse Estado a fim de contribuir para o desenvolvimento da sociedade. Alguns entendem, no entanto, que o papel do Banco Central não deveria observar questões de foro político para o desenvolvimento de suas atividades, por serem elas eminentemente técnicas. Este capítulo da dissertação versará sobre o legítimo papel dessa instituição.

Será adotado o ponto de vista segundo o qual, por ser parte do Estado, os Bancos Centrais deverão sempre executar suas atividades de forma coordenada com a política 
econômica por ele delineada. Com o objetivo de demonstrar que o exercício da política monetária vai além da apreciação puramente técnica dos dados econômicos disponíveis aos dirigentes do Banco Central, será essencial buscar nos objetivos do Estado de Direito o fundamento para o desempenho coordenado das atividades desse órgão.

Com base em opiniões extraídas da doutrina, bem como em alguns exemplos de Bancos Centrais selecionados de acordo com sua relevância para o desenvolvimento deste trabalho, será possível verificar que, muitas vezes, a prática demonstra que o exercício da política monetária ocorre sem se considerarem determinados aspectos relevantes da realidade social. A inspiração encontrada nessas experiências possibilitará algumas conclusões, no capítulo seguinte, sobre o modelo de banco central adotado no Brasil e sua adequação aos anseios da sociedade contemporânea brasileira.

\subsection{Política Econômica}

De maneira muito sucinta, pode-se dizer que Política é a ciência desenvolvida com a finalidade de organizar, dirigir e administrar as relações estabelecidas entre os homens para possibilitar a sua convivência harmônica em sociedade.

A política econômica, por sua vez, consiste na atuação do Estado nas relações financeiras estabelecidas entre os homens, a fim de organizá-las, possibilitando o enriquecimento da nação de forma equilibrada. Nesse contexto, o Direito Econômico alicerçou-se de acordo com a crescente necessidade de regular a intervenção do Estado a fim de direcionar aplicações de recursos escassos para o cumprimento de objetivos socialmente necessários, tais como controlar a distribuição de renda, conter crises, garantir o bem-estar dos cidadãos e promover o desenvolvimento social.

Da análise no capítulo primeiro sobre os efeitos decorrentes da adoção das teorias liberais, constatou-se que não há “mão invisível”, tampouco a possibilidade de se deixar o mercado sob a tutela exclusiva da autorregulação ${ }^{110}$, pois, se assim fosse, não haveria o

\footnotetext{
${ }^{110} \mathrm{~A}$ autorregulação foi anunciada como fruto das forças equilibradoras do mercado. Todavia, com a prática, verificou-se que o exercício da autorregulação ocorre sempre coordenadamente com a regulação Estatal e de modo auxiliar. Sua vantagem mais destacada reside no objetivo de controlar com maior grau de especificidade e proximidade o desenvolvimento da atividade privada para conferir-lhe maior segurança, dado que os reguladores são, nesse caso, os próprios agentes do mercado. YAZBEK, Otavio. op. cit., p. 209 , destaca que a autorregulação tem como característica principal ser um tipo de regulação artificial criada pela própria coletividade de agentes regulados, de caráter extra-estatal, desenvolvida por órgãos
} 
direcionamento da política econômica para o alcance dos objetivos maiores da sociedade. Daí a importância da formulação e execução de tal política econômica coordenadamente com as demais políticas voltadas à integração e ao desenvolvimento da sociedade.

Ao destacar, a partir de 1930, a transformação dos objetivos da política econômica, Eugênio Gudin relata:

A ênfase passou então para o incremento da produção e do volume do
emprego. O objetivo geral da política econômica passou a ser o do maior
e melhor (melhor no sentido de produtividade) aproveitamento dos
fatores de produção. E a maior e melhor utilização possível dos recursos
materiais e do potencial humano, de modo a maximizar a renda nacional
e o padrão de vida. Tal política importa forçosamente no combate as
oscilações gerais da atividade econômica, por meio de medidas tendentes
a manter em alto nível a renda nacional e o volume de emprego ${ }^{111}$.

Divide-se a política econômica em política monetária (moeda e crédito), política cambial (câmbio, entradas e saídas de divisas, relações financeiras com o exterior) e política fiscal (matéria tributária e orçamentária).

Embora existam subdivisões materiais na política econômica, são apenas organizativas; devem ser desenvolvidas de forma integrada para possibilitar o alcance de determinados fins. Nesse sentido, todas essas subdivisões deveriam observar as diretrizes determinadas pelo Estado, sem prejuízo de terem suas funções desempenhadas por órgãos técnicos designados para o exercício de tais políticas.

Este trabalho, a despeito de, em alguns momentos, tangenciar matérias de competência das políticas fiscal e cambial, está voltado à análise específica da política monetária pelos Bancos Centrais, mas frise-se que não existe o desenvolvimento de uma política monetária independente das políticas fiscal e cambial, porque as três se complementam e são partes do todo que compõe a política econômica e essa, por sua vez, traduz os objetivos do Estado de Direito.

coletivos privados e que corporifica as faculdades de autorregulamentação, autoexecução e autodisciplina. Portanto, ela é fruto da necessidade das entidades privadas de criarem regras de controle que possibilitem a higidez, a preservação de sua atividade. Mas, sem prejuízo de sua natureza privada, a autorregulação necessariamente deve integrar-se com a atividade regulatória estatal, pois sozinha não é suficiente.

${ }^{111}$ GUDIN, Eugênio. op. cit., v. 2, p. 3. 


\subsection{Política Monetária: Conceito e Objeto}

A política econômica exercida pelo Estado apoia-se na política monetária como um de seus principais alicerces. O exercício da política monetária (geralmente conferido por determinação normativa) dá-se pelo Banco Central, que detém o monopólio da emissão da moeda $^{112}$. Assim, essa política pode ser identificada como a ação do Estado, por meio do Banco Central, para controlar a oferta de moeda garantindo a sua estabilidade, contraindo e expandindo o crédito no mercado de forma coordenada com as políticas físcal e cambial.

O objetivo final da política monetária é o de promover o bem-estar da sociedade. Embora poucos discordem desse objetivo, conforme visto no capítulo anterior, há uma série de divergências sobre como atingi-lo. Aqueles que acreditam na tese monetarista propugnam pela estabilidade da moeda como objetivo principal a ser perseguido pela política monetária. Os keynesianos, por sua vez, defendem que o nível de emprego influirá diretamente no bem-estar, de forma que este deve ser o objetivo da política monetária. Além disso, de acordo com os seguidores de Keynes, se o banco central se utilizar de uma política monetária de caráter mais expansionista, poderá abreviar períodos de recessão e promover o desenvolvimento. O presente trabalho orienta-se de acordo com esta segunda posição, a respeito do objetivo final da política monetária.

A matéria da política monetária envolve, prioritariamente, o estudo da moeda e das relações de crédito, temas imprescindíveis para a compreensão do alcance das atividades desempenhadas pelo Banco Central. Nesse sentido, vale buscar, de maneira bastante sucinta, o conceito dos dois principais objetos de estudo deste trabalho: moeda e crédito.

\footnotetext{
${ }^{112} \mathrm{O}$ monopólio da emissão da moeda pelo Banco Central já foi objeto de contestação. Hayek propugnava que, com a desestatização da moeda, a atividade do Banco Central ficaria esvaziada ante a impossibilidade de exercer a política monetária que, a seu ver, era realmente desnecessária. $\mathrm{O}$ autor resgatou e passou a defender a antiga teoria do Free Banking, em que cada banco se responsabilizaria pela conversão de suas moedas e passivos. Cumpre destacar que o Free Banking previa o fim do monopólio de emissão monetária e a inexistência de uma autoridade monetária hábil a fiscalizar/controlar/autorizar o funcionamento das instituições financeiras. Os Estados Unidos tiveram essa experiência após uma grande crise monetária em 1837, mas, pouco depois, voltaram atrás. HAYEK, Friedrich A. A desestatização do dinheiro: uma análise da teoria e prática das medidas simultâneas. Tradução de Heloisa Gonçalves Barbosa, Rio de Janeiro: Instituto Liberal, 1986. p. 97. Realmente começamos a perceber o quanto seria diferente o panorama econômico produzido pela livre emissão de moedas concorrentes quando nos damos conta de que, sob tal sistema, o que se conhece hoje como política monetária não seria nem necessário nem sequer possível. Os bancos emissores, guiados somente por sua busca de lucro, serviriam ao interesse público melhor do que qualquer instituição que supostamente tivesse isso como meta jamais fez ou poderia fazer.
} 
Em muitas obras ${ }^{113}$ acadêmicas que se prestam a definir moeda, o que usualmente se verifica são divagações sobre a sua forma física, os materiais utilizados em sua confecção, os fatos históricos sobre o escambo de mercadorias e sua evolução até os meios de pagamento hoje utilizados. Outra tentativa recorrente de conceituação da moeda acaba por resumir-se à descrição de suas funções ${ }^{114}$, o que possibilita a sua caracterização, mas não é suficiente para apreender seu significado de forma satisfatória.

Conforme lição de Eugênio Gudin ${ }^{115}$, a moeda no século XX é essencialmente um negócio de Estado, regulada ao sabor de seus interesses, sendo completamente indiferente a maneira pela qual é representada materialmente, pois a força liberatória dada à unidade de valor e a sua aceitação geral dentro de uma certa ordem são os verdadeiros definidores da moeda.

Ainda segundo Gudin, a moeda é um precioso instrumento do progresso econômico que possibilita ao consumidor generalizar seu poder de compra e extrair da sociedade aquilo que a sua disponibilidade monetária lhe dá direito, da maneira que mais lhe convier: é o instrumento da liberdade de escolha ${ }^{116}$.

Com efeito, essa unidade de valor na qual se alicerçou toda a economia mundial capitalista foi amplamente estudada por José Tadeu De Chiara em sua tese de doutoramento. $\mathrm{O}$ autor, por meio de seu trabalho acadêmico, elucidou o conceito de moeda como um produto da linguagem jurídica que, senão dentro de uma ordem constituída, está desprovido de qualquer significado e função.

Dessas considerações resulta que, do ponto de vista das relações
jurídicas, a referência à moeda não implica a identificação de um
instrumento físico, ou de um conjunto de funções agrupados, ou, ainda,
de quantidades de bens que possam ser adquiridas. No âmbito do sistema
de leis a moeda é indicada apenas por um vocábulo, a partir do que se
desenvolvem funções e condicionamentos que derivam, as primeiras, de
mecanismos previstos pelo ordenamento (tais como compensação,
tradição de moeda divisionária, emissão de cheques, entre outros), es
segundos, de situações engendradas nos mercados que induzem

${ }^{113}$ YAZBEK, Otavio, na obra Regulação do mercado financeiro e de capitais, cit., discorre sobre as inovações financeiras e a evolução da regulação do mercado financeiro e de capitais; em explicação bastante pertinente ao contexto de sua análise, destaca que a moeda é, na verdade, a primeira grande inovação financeira, p. 70 e ss.

${ }^{114} \mathrm{~A}$ definição clássica de moeda privilegia os ativos financeiros que são usados como meios de pagamentos. Dessa forma, a moeda (historicamente representada pelo símbolo M) é definida como: a) papel-moeda em poder do público; mais b) depósitos à vista do público. ALMEIDA, José Roberto Novaes de. Economia monetária. São Paulo: Atlas, 2009. p. 84. Eis um conceito insuficiente do que seja a moeda, publicado em obra recente.

${ }^{115}$ GUDIN, Eugênio. op. cit., v. 1, p. 25.

${ }^{116}$ Id. Ibid., p. 27. 
diferentemente a ação de agentes, ou categoria de agentes. Assim, em termos conceituais, na ordem jurídica, a moeda constitui expressão da linguagem que encontra sentido unicamente quando utilizada sob certas regras de direito e em certo sistema de direito positivo. ${ }^{117}$

Por exemplo, a moeda adotada no Brasil atualmente, o "Real", possui significado perante a ordem jurídica brasileira que permite conferir à unidade de valor - a qual expressa - a possibilidade de ser utilizada em suas quatro funções: padrão geral de troca, reserva de valor econômico, padrão geral de valor e instrumento de pagamento. Se, de repente, o Estado brasileiro voltar a utilizar o "Cruzeiro" ", a partir do momento em que o arcabouço normativo designador dessa moeda como oficial estiver em vigor, o Real não terá qualquer significado perante a ordem social considerada, tampouco poderá ser utilizado em nenhuma de suas quatro funções originais; não será, portanto, moeda. Já o Cruzeiro será o novo padrão monetário dotado de curso legal.

Nesse sentido, De Chiara esclarece que a moeda não deve ser identificada apenas pelas funções que exerce, tampouco pela quantidade de bens que possa adquirir, nem mesmo por um instrumento físico de metal ou papel, mas como expressão de linguagem admitida em certa ordem jurídica, sob determinadas regras de direito. É esse referencial que permite a organização e funcionamento do sistema. Assim, ela é, ao mesmo tempo, objeto (por ser definida pelo direito) e parâmetro (pois todas as normas do subsistema econômico do direito se baseiam nela).

Ao se observarem as relações jurídicas de conteúdo patrimonial, verifica-se que uma das partes do negócio será o sujeito de direito titular do instrumento monetário. Isso significa que o sujeito é titular do critério estabelecido pela ordem, para exercitar direitos de conteúdo patrimonial ou exonerar deveres. Essa relação jurídica constrói-se em razão dos qualificativos que esse instrumento encontra no sistema de direito positivo. Os qualificativos do instrumento monetário ensejam que o titular que detém moeda possa exercitar direito de conteúdo patrimonial em qualquer parte da ordem social. É esse o poder liberatório mencionado por Gudin e explicado por De Chiara.

\footnotetext{
${ }^{117} \mathrm{DE}$ CHIARA, José Tadeu. Moeda e ordem jurídica. Tese (Doutorado) - Faculdade de Direito, Universidade de São Paulo, USP, São Paulo, 1986. p. 58.

${ }^{118}$ Moeda vigente no Brasil entre $1 .^{\circ}$ de novembro de 1942 e 12 de fevereiro de 1967.
} 
Vale, por fim, resgatar as impressões de Comparato ${ }^{119}$ a respeito do poder liberatório da moeda na ordem social na qual se insere, classificando-a como instituição pública:

\begin{abstract}
A segurança nas transações constitui, de fato, a essência da chamada ordem pública econômica, cuja manutenção é tarefa fundamental do Estado. Sendo ela intimamente vinculada ao sistema monetário, o monopólio de emissão de moeda, reconhecido desde a mais remota antigüidade como atributo soberano, desdobra-se no dever público de garantir um mínimo de estabilidade à moeda oficial em sua função de medida de valor e instrumento de pagamento. As moedas não são, pois, uma livre criação dos agentes econômicos, mas instituições públicas. Em todos os Estados há uma moeda de curso legal, isto é, que circula oficialmente por emissão do poder estatal, e que não pode, por isso mesmo deixar de ser aceita como meio de pagamento.
\end{abstract}

Dado brevemente o conceito de moeda, cabe analisar-se o conceito de crédito, o outro objeto da política monetária que deriva das relações negociais entre aqueles que utilizam a moeda.

O crédito ${ }^{120}$ deriva da moeda. Grosso modo, trata-se da renúncia à liquidez por uma das pontas da relação jurídica - o credor - em favor do pagamento de juros (o preço da renúncia à liquidez) pela outra ponta - o devedor. Ao obter o crédito, o indivíduo que, inicialmente, estava impossibilitado de desempenhar sua atividade/investimento/projeto, poderá fazê-lo, observando-se que, após o transcurso do prazo previamente definido, o devedor será obrigado a devolver o valor inicialmente tomado como empréstimo, com o pagamento de um acréscimo correspondente à taxa remuneratória que, aos olhos do credor, justifique o seu ato de renunciar temporariamente à liquidez proporcionada pela posse da moeda.

\footnotetext{
${ }^{119}$ COMPARATO, Fábio Konder. Cláusulas contratuais de indexação de preços. Revista de Direito Mercantil, Industrial, Econômico e Financeiro, São Paulo, v. 85, p. 35, 1992.

${ }^{120} \mathrm{O}$ crédito tem conceito plurívoco, podendo ser conceituado de diversas maneiras, de acordo com o campo de análise a que se refira. No âmbito do direito civil, crédito representa a relação bilateral cujo objeto é a transferência da disponibilidade monetária do credor ao devedor; vale dizer, permite que o devedor cumpra sua parte em tempo futuro, permitindo àqueles com insuficiência de renda exercitar negócios jurídicos de natureza econômica. No plano do direito comercial, crédito representa um dos elementos que compõe o aviamento do empresário, agregando valor à empresa, pois o empresário reconhecido como "bom pagador" no mercado em que atue sempre poderá obter financiamento de sua atividade empresarial a um custo menor, o que certamente contribuirá para a prosperidade do estabelecimento. No campo do direito público, crédito significa realização de despesa pelo Estado, o que pode ser feito a partir do cumprimento da receita orçamentária previamente estabelecida, ou por um endividamento público por meio da emissão de títulos públicos colocados à venda no mercado. Nesse sentido, o Estado pode-se endividar por diferentes meios a fim de realizar o negócio jurídico de crédito.
} 
Trata-se, portanto, de um instituto típico das relações privadas ${ }^{121}$ e, também, de um combustível essencial à saúde econômica de qualquer nação, portanto ferramenta imprescindível da política econômica, no âmbito do direito público.

A causa do negócio jurídico de crédito e o motivo pelo qual ele é tão importante considerado o modo de produção capitalista residem no fato de que, ao capitalizar-se, o agente econômico poderá optar por investir (ele também poderá optar por consumir ou mesmo poupar a uma taxa remuneratória melhor do que aquela que pagou pelo crédito original) em alguma atividade produtiva, gerar empregos, obter lucro e conceder créditos a terceiros, fomentando o incremento da atividade econômica.

Joseph A. Schumpeter consolida, em sua obra A Teoria do Desenvolvimento Econômico $^{122}$, a importância do crédito como elemento determinante desse desenvolvimento.

\begin{abstract}
Nesse sentido, portanto, definimos o cerne do fenômeno do crédito da seguinte maneira: o crédito é essencialmente a criação de poder de compra com o propósito de transferi-lo ao empresário, mas não simplesmente a transferência de poder de compra existente. A criação de poder de compra caracteriza, em princípio, o método pelo qual o desenvolvimento é levado a cabo num sistema com propriedade privada e divisão do trabalho. Através do crédito, os empresários obtêm acesso à corrente social dos bens antes que tenham adquirido o direito normal a ela. Ele substitui temporariamente, por assim dizer, o próprio direito por uma ficção deste. A concessão de crédito opera nesse sentido como uma ordem para o sistema econômico se acomodar aos propósitos do empresário, como um comando sobre os bens de que necessita: significa confiar-lhe forças produtivas. É só assim que o desenvolvimento econômico poderia surgir a partir do mero fluxo circular em equilíbrio perfeito. E essa função constitui a pedra angular para a moderna estrutura de crédito.
\end{abstract}

Assim, a possibilidade de incorporação da disposição de bens e recursos a serem produzidos somente se concretiza por meio do crédito, veículo que permite aos empresários aprimorarem suas atividades por meio da inovação.

\footnotetext{
${ }^{121} \mathrm{Si}$, au point de vue moral, le crédit repose sur la confiance, déterminée par des facteurs économiques ou juridiques, et dans un autre ordre d'idées par la personne même du débiteur futur, au point de vue juridique le crédit repose sur le contrat lui-même. LESTAPIS, Pierre de. La notion juridique de cédit. Paris: Librairie Générale de Droit \& de Jurisprudence, 1941. p. 168.

${ }^{122}$ SCHUMPETER, Joseph Alois. A teoria do desenvolvimento econômico. Tradução de Maria Silvia Possas. São Paulo: Abril Cultural, 1982. p. 74.
} 
Verifica-se a inovação pela atuação do empresário, concretizando-se quer pela produção de um produto novo, quer pelo acesso a novas fontes de matéria-prima, que por uma nova organização da produção, quer pelo acesso a novos mercados, quer, ainda, pela adoção de um novo método de produzir. Desta forma, promovida a inovação, há a possibilidade de ganhos qualitativos em termos de produtividade que geram, naturalmente, aumento de produção do aspecto quantitativo, do que resulta o dinâmico processo do desenvolvimento econômico ${ }^{123}$.

Se, no período que compreendeu a boa parte dos séculos XIX e XX, o Estado esteve adstrito à função de garantir a estabilidade e a segurança dos contratos e das relações negociais a fim de proporcionar o estímulo e a multiplicação das relações de crédito, hoje, por meio dos mecanismos da política monetária, o Estado está habilitado a atuar como o verdadeiro indutor da contração e expansão ${ }^{124}$ do crédito e, por conseguinte, do processo produtivo, de acordo com os objetivos que queira alcançar em termos de política econômica.

Conforme visto no capítulo anterior, o Estado, a partir da segunda década do século $\mathrm{XX}$, passou a ser o principal agente econômico tomador e emprestador de moeda com o objetivo de fomentar e controlar a atividade econômica. A política de crédito desenvolvida desde então, consolidou-se como o motor fundamental para o desenvolvimento da sociedade capitalista ${ }^{125}$, a qual não poderia evoluir e alcançar o estágio atual sem que

${ }^{123}$ DE CHIARA, José Tadeu. Disciplina jurídica das instituições financeiras. Revista de Direito Público, São Paulo, v. 41/42, p. 289, 1977.

${ }^{124} \mathrm{KOCH}$, Arwed. El credito en el derecho. Tradução de Jose $\mathrm{M}^{\mathrm{a}}$ Navas. Madrid: Revista de Derecho Privado, 1946, autor alemão, escreveu sobre o crédito logo depois da estabilização do marco; o autor relata da seguinte forma a transformação da oferta de crédito antes e após a estabilização da moeda naquele país: "Durante la inflación, y aproximadamente desde fines del año, no puede hablarse ya de depósitos de dinero en los Bancos, y las existencias en cuentas corrientes eran tan pequeñas y circulaban tan rápidamente, que no servían para la concesión por los Bancos de créditos a terceros. Los Bancos, ante nuevas operaciones de préstamo, estaban limitados por completo a sus propios medios. (...) Examinemos ahora la situación después de la estabilización del marco, esto es, a partir de 20 de noviembre de 1923, el día en que el dólar se pagó a 4 billones 200.000 millones de marcos papel. La situación se caracterizó por los siguientes momentos: falta extraordinaria de capital, a consecuencia de la estabilización del marco, de donde resultó un estancamiento de toda la economía; gastos extraordinariamente altos por aparato administrativos introducido por la inflación; desconfianza nacional y extranjera hacía una satisfactoria estabilización monetaria; enormes tipos de interés por el dinero a la vista y a plazos en las plazas bursátiles, a causa de la falta de capital y de la mencionada desconfianza. Estos hechos eran, naturalmente, decisivos en la formación del tipo de interés, y así como el precio de una mercancía se determina por la oferta y la demanda, también habrá de aplicarse este principio a los intereses de los préstamos." p. 161-165.

${ }^{125}$ “O crédito é um dos caracteres essenciais da economia moderna. Do ponto de vista técnico, a produção é cada vez mais capitalista. Empregam-se métodos cada vez mais indiretos de produção, que permitem melhor aproveitamento dos fatores de produção. Daí resulta um intervalo de tempo crescente decorre entre o início e a conclusão do processo de produção. É somente contra o produto acabado, que o consumidor paga a mercadoria. Este pagamento é feito, geralmente, à vista, mas todo o processo de produção implica necessariamente no recurso ao crédito. Porque, ou todos que participaram da produção esperaram pagamento até que o consumidor tivesse pago, e, nesse caso, concederam crédito, pois o que forneceram a 
houvesse o decisivo papel do Estado como formulador de uma política de crédito voltada para esses fins.

Logo, utilizando-se de instrumentos específicos, a autoridade monetária tem condições de influir no comportamento da atividade econômica com vistas a determinar as condições de liquidez do mercado por meio da expansão ou contração da base monetária e do controle seletivo do crédito $^{126} \mathrm{e}$, dessa maneira, induzir a propensão de consumir, poupar e investir.

\subsection{Instrumentos para o exercício da Política Monetária}

Os instrumentos da política monetária são as variáveis que o Banco Central pode manipular diretamente para atingir os objetivos estabelecidos para a política monetária.

A seguir, será feita a análise desses mecanismos quais sejam: o redesconto bancário, as reservas compulsórias sobre os depósitos do sistema bancário, o mercado de títulos públicos e as taxas de juros no mercado de reservas bancárias.

\subsubsection{Os Redescontos Bancários}

Uma das atribuições do Banco Central é ser o "banco dos bancos". Historicamente, como visto no capítulo anterior, o redesconto consistia no desconto, pelo Banco Central de título apresentado pelo banco comercial, como forma de adiantamento ao pagamento que o mencionado banco receberia de seu cliente depois de um determinado prazo. Para efetuar o redesconto do título apresentado, o Banco Central cobrava uma 'taxa de redesconto', que eram os juros pelo adiantamento do valor ${ }^{127}$.

prestação sem receber a contraprestação, ou então o crédito foi suprido por algum banco ou capitalista, que adiantou os recursos, sucessivamente, aos fabricantes e negociantes.” GUDIN, Eugênio. op. cit., v. 1, p. 56.

126، Do ponto de vista do controle seletivo do crédito, a atuação do Estado se efetiva pela determinação de percentuais a serem observados pelas instituições financeiras nas operações de crédito que contratam, em termos de limite máximo para pessoas estrangeiras, pela imposição de deferir crédito para atividades rurais, ou, ainda, mediante condições especiais de crédito para pequenas empresas”. DE CHIARA, José Tadeu. op. cit., p. 101. Disciplina jurídica das instituições financeiras, cit., p. 289-307.

127 "O redesconto deve ser considerado como um meio de socorrer temporariamente os bancos que, por quaisquer circunstâncias, necessitem reforçar sua posição de caixa em relação aos depósitos. No exercício do redesconto, podem os banco centrais facilitar ou dificultar a operação, conforme a orientação de sua política de crédito, a cada momento. Para isso, eles podem fazer variar o preço do redesconto, isso é a taxa se juros cobrada". GUDIN, Eugênio. op. cit., v. 1, p. 224. 
Modernamente, o redesconto é uma forma de empréstimo concedido às instituições financeiras privadas que são intermediárias financeiras e membros do sistema de pagamentos. O redesconto pode ser de liquidez, que consiste em empréstimo rotineiro, concedido aos bancos comerciais os quais, porventura, não possuam saldo suficiente no momento das compensações, ou, ainda, redescontos especiais feitos pelo Banco Central a fim de conceder benefícios a setores específicos que eventualmente tenham abalada a sua liquidez por algum fato econômico superveniente e não controlável.

Há duas formas de efetuar o redesconto e ambas pressupõem o financiamento da instituição ilíquida envolvendo ativos, o que diminui o risco de inadimplência ${ }^{128}$. A primeira forma de redesconto ocorre por meio da aquisição pelo Banco Central de títulos e valores mobiliários, créditos ou direitos creditórios detidos pela instituição financeira titular de conta de "reserva bancária" com compromisso de recompra assumido pela própria instituição financeira. No momento da recompra, a instituição financeira adquire esses títulos a um preço maior, a fim de remunerar o capital empregado na aquisição dos títulos pelo Banco Central.

A outra forma, mais tradicional, é o redesconto propriamente dito, por meio do qual a instituição financeira apresenta e "redesconta" títulos em seu nome perante o Banco Central e permanece responsável pela cobrança dos devedores originais desses títulos, comprometendo-se a recomprá-los em data previamente acordada.

Tal ferramenta pode ser utilizada como instrumento de política econômica, embora não seja esta a sua principal finalidade ${ }^{129}$. Esse mecanismo funciona em razão do valor da taxa cobrada pelo Banco Central para realizar o redesconto, ou seja, se for uma taxa inferior à adotada no mercado, as instituições financeiras são incentivadas a elevar seu crédito no Banco Central e a expandir a concessão de créditos ao mercado, o que por sua vez aumenta a quantidade de moeda em circulação.

Alternativamente, em busca do efeito inverso, o Banco Central pode cobrar uma taxa alta para efetuar o redesconto, acima da cobrada pelo mercado e, consequentemente, os bancos reduzirão a utilização do redesconto como forma de obter crédito perante o Banco Central e reduzirão sua oferta de crédito aos clientes, atitude que ensejará uma

\footnotetext{
${ }^{128}$ SALOMÃO NETO, Eduardo. Direito bancário. São Paulo: Atlas, 2005. p. 524.

${ }^{129}$ A principal função do redesconto é a de evitar um colapso do sistema por uma crise generalizada de liquidez e não servir como instrumento de política monetária, embora na prática seja bastante utilizado pelo Banco Central com esse objetivo.
} 
diminuição geral da oferta de crédito no mercado e, automaticamente, a contração da base monetária.

Conforme pontua Novaes de Almeida ${ }^{130}$, o principal efeito positivo do redesconto é a possibilidade de controlar a instituição financeira que está em condições de atuar de forma não coordenada com a política definida pelo banco central (por meio do aumento ou da diminuição da taxa de redesconto ou das garantias exigidas para efetuá-lo - que faz com que o banco inicialmente propenso a contrair a sua oferta de crédito fique inclinado a aumentá-la ou a diminuí-la).

O mesmo autor destaca como desvantagens do redesconto, porém, o fato de ser um instrumento sobre o qual os bancos privados estão no controle, pois se trata de mera "faculdade" a utilização desse mecanismo quando há a necessidade de disponibilidade monetária imediata. Em muitos casos, os bancos privados não desejam tornar conhecida a sua situação de liquidez pelo Banco Central e, por isso, não tomam recursos no redesconto, buscando capitalizar-se no mercado, às vezes a um custo até maior, o que faz com que, na perspectiva do Banco Central, o redesconto não seja um bom indicador da liquidez bancária.

Cumpre destacar que a função de "banco dos bancos" exige a fixação de determinados limites por parte do Banco Central, sob pena de comprometimento da higidez do sistema. Em situações de crise, por exemplo, o Banco Central fica sob extrema pressão para reduzir as garantias exigidas aos devedores, o que pode implicar grandes perdas.

O papel de prestamista de última instância representa uma das funções mais essenciais do Banco Central. Porém, não representa um dever de fornecer socorro ilimitado aos bancos em qualquer circunstância. Isso porque a certeza de contar com um suporte certo e ilimitado do Banco Central estimularia os bancos a assumir riscos cada vez maiores (problema do moral hazard). Dessa forma, a instabilidade intrínseca da atividade bancária aumentaria de forma considerável agravando o potencial de crise e suas consequências nefastas para o conjunto da economia. ${ }^{131}$

Por esse motivo, as instituições privadas desempenham papel fundamental no equilíbrio da economia e devem ter sua higidez preservada como condição essencial para a

\footnotetext{
${ }^{130}$ ALMEIDA, José Roberto Novaes de. op. cit., p. 114. O autor, professor de economia na Universidade de Brasília e economista do Banco Central do Brasil, foi diretor de relações internacionais dessa instituição.

${ }^{131}$ FREITAS, Maria Cristina Penido de op. cit., p. 30.
} 
estabilidade financeira de qualquer país. No que tange a esse quesito específico, vale uma breve incursão, conforme a seguir.

O papel principal dos bancos privados consiste em captar a poupança individual e direcionar esses recursos para aqueles que precisam investir na atividade produtiva. As instituições bancárias são típicas intermediárias financeiras por se colocarem entre o poupador e o tomador de empréstimos, criando relações distintas e independentes com cada um deles, mas correlacionadas.

Além disso, os bancos desempenham papel fundamental para o bom funcionamento do sistema de pagamentos por meio do qual grande parte das relações de pagamento da sociedade é realizada.

A quebra de um banco pode gerar a ocorrência de crise no sistema inteiro, pelo fato de, potencialmente, abalar o sistema de pagamentos e, como consequência, a economia toda. Desse modo, as atividades bancárias devem receber regulamentação específica, bem como tratamento especial por parte do Estado.

Tiago Cortez, em sua tese de doutoramento, define risco sistêmico da seguinte forma:

(...) a idéia de risco sistêmico, ao menos no que se refere ao setor bancário, se baseia em três elementos: choques, contágio (ou mecanismos de transmissão) e resultados que incluam a possibilidade de quebra de outras instituições financeiras. Considerando-se esses três elementos básicos pode-se dizer que risco sistêmico de um setor bancário é o risco de que a quebra de um banco, ou de qualquer outro fato, contagie uma ou outras instituições, resultando na quebra de uma ou mais instituições que "anteriormente" se encontravam solventes. ${ }^{132}$ (sic)

A existência de risco sistêmico consiste, portanto, na possibilidade de que vários bancos venham a quebrar em razão de algum acontecimento específico. De um lado, legitima as autoridades governamentais a tomarem as atitudes que entendam necessárias para a prevenção e manutenção da estabilidade do sistema, inclusive salvando alguns bancos para evitar uma quebradeira geral.

Com efeito, os bancos estão suscetíveis ao risco sistêmico conforme pode ser constatado pela análise de seus balanços. Os ativos dos bancos constituem-se de empréstimos concedidos aos seus clientes que podem ter variados prazos de duração. $\mathrm{O}$

\footnotetext{
${ }^{132}$ CORTEZ, Tiago Machado. Moeda, Estado e direito: o papel do Estado na ordem monetária e seu controle.
} 2004. Tese (Doutorado) - Faculdade de Direito, Universidade de São Paulo, USP, São Paulo, 2004. p. 318. 
passivo do banco é constituído de depósitos à vista, prontamente disponíveis aos saques de seus clientes. Assim, tendo em vista que os bancos não podem negar a devolução do valor depositado por falta de liquidez, a situação patrimonial bancária é bastante arriscada.

Pode-se dizer que os bancos incorrem num risco relativo à estrutura temporal de suas obrigações, tendo em vista que não há possibilidade de sincronizar o vencimento de suas obrigações passivas com o vencimento de suas obrigações ativas.

Daí justificada a importância do redesconto, não somente em relação ao controle da base monetária, mas, principalmente, no que concerte à higidez do sistema financeiro.

\subsubsection{Reservas Compulsórias}

A ampliação da renda disponível em função do efeito multiplicador que decorre da prática bancária gerando moeda escritural e expandindo a massa monetária deve estar sujeita ao controle do Banco Central.

Os bancos, ao exercerem a atividade de intermediação financeira, geram efeito multiplicador da base monetária, criando a chamada "moeda escritural", isso porque os depósitos efetuados pelos correntistas raramente são integralmente sacados (com exceção dos momentos de crise financeira, em que se verifica o risco sistêmico, conforme apontado acima). Esse controle quantitativo do crédito funciona de modo que quanto maior o volume recolhido de depósitos, menor a quantidade de moeda escritural gerada pelos bancos e menor a disponibilidade desses em conferir crédito.

A moeda física em circulação representa uma parcela reduzida se considerada a totalidade dos meios de pagamentos existentes. O que ocorre geralmente não é o saque, mas a transferência do crédito de uma pessoa a outra, por meio do banco.

O mecanismo de criação de moeda nos registros contábeis dos bancos se processa em termos de quantias registradas em depósitos, inclusive com base na concessão de crédito pelas diferentes modalidades de operações bancárias. Esses depósitos que instrumentam pagamentos, por sua vez geram novos créditos em contas de depósito, que atuam da mesma forma sobre a relação encaixe/depósitos. Apenas uma parte do total dos depósitos é conservada como encaixe para atender saques, e, o remanescente, instrumenta a concessão de créditos ${ }^{133}$.

\footnotetext{
${ }^{133}$ DE CHIARA, José Tadeu. Moeda e ordem jurídica, cit., p. 83.
} 
O Banco Central, como meio de preservar a estabilidade do mercado - precavendose, inclusive, de uma eventual corrida aos bancos $^{134}$, e também como meio de executar sua política monetária, determina que parcela dos valores detidos pelos bancos comerciais, como resultado das atividades de intermediação financeira que realizam, seja mantida em seu poder a título de reserva compulsória, o que interfere diretamente no efeito multiplicador dos depósitos.

Assim, se o Banco Central aumentar ou diminuir o volume de reservas compulsórias, automaticamente diminuirá ou expandirá a quantidade de moeda no mercado, e, consequentemente, de crédito.

Novaes de Almeida ${ }^{135}$ ressalta as desvantagens do compulsório o que, segundo o autor, torna a sua utilização reduzida em países desenvolvidos, pois, este método implica colocar alguns bancos em dificuldade:

a) com o aumento da taxa de compulsório, alguns bancos podem apresentar problemas de liquidez. Daí resulta, paradoxalmente, que o banco central, ao aumentar a taxa do compulsório, deve esperar um aumento de seu crédito no banco, pelo redesconto, o que implica efeito oposto sobre a direção desejada da base. Alternativamente, o banco central aumenta o compulsório, permitindo longo período de ajuste, para evitar problemas de liquidez bancária;

b) o compulsório é um instrumento pesado, que não serve para calibração cirúrgica. Não é um instrumento que permite atingir um banco específico, mas a totalidade do sistema, o que inibe a sua utilização pontual;

c) mesmo mudanças pequenas na taxa do compulsório podem ocasionar dificuldades para bancos com problemas de liquidez ou de crédito em regiões específicas do país. Daí que o instrumento deva ser utilizado com cautela;

d) a mudança na taxa do compulsório, se feita abruptamente, pode causar resultados imediatos desconhecidos, uma vez que, se a variação total do multiplicador da base monetária for conhecida previamente, a trajetória de mudança do multiplicador não o será;

\footnotetext{
${ }^{134}$ Fenômeno conhecido na economia, a corrida aos bancos ocorre nos momentos em que as situações de crise tornam-se iminentes. A população literalmente "corre" aos bancos para sacar seus depósitos - pois teme que os bancos deixem de honrá-los, o que deixa as instituições financeiras com reduzida liquidez e dificuldades em cumprir as obrigações assumidas perante outros clientes e, mesmo, perante o Banco Central.

${ }^{135}$ ALMEIDA. José Roberto Novaes de. op. cit., p. 116.
} 
e) taxas elevadas de compulsório podem afetar o crédito bancário aumentando excessivamente o spread entre taxas de juros ativas e passivas do banco, o que inibe o crédito à economia e

f) o compulsório reduz o lucro dos bancos. É claro que não se desejam lucros excessivos no sistema bancário, mas é importante manter a integridade do sistema financeiro.

Duas considerações a respeito das desvantagens apontadas pelo autor, no que concerne ao compulsório, merecem reparo. Inicialmente, no que tange à possibilidade de colocar os bancos em 'situação difícil', leia-se aqueles bancos menos organizados financeiramente, haja vista o fato de que os compulsórios são mecanismos dos quais os Bancos Centrais podem utilizar-se a qualquer momento, devendo os integrantes do sistema financeiro estar preparados para arcar com esse tipo de intervenção sem que isso comprometa a sua liquidez.

Assim, se o objetivo for conferir segurança e estabilidade ao sistema, aquelas instituições menos organizadas deverão buscar adequar-se às exigências do sistema, ou arcar com as consequências decorrentes de seu funcionamento. Isso somente demonstra o quanto esse mecanismo pode ser eficaz.

Adicionalmente, quanto à última desvantagem apontada pelo autor - de que o compulsório reduz o lucro dos bancos -, cabe a crítica de que a "redução" de lucros das instituições financeiras não necessariamente afetará a integridade do sistema financeiro, porque, neste caso, o Banco Central utiliza o mecanismo como forma de controle das disponibilidades de reservas dos bancos comerciais. Se sopesada a relevância da diminuição do "lucro dos bancos" em contrapartida à execução de uma política monetária eficaz, certamente não haverá dúvidas de qual estratégia seguir. 


\subsubsection{Open Market}

O mercado aberto (open market ${ }^{136}$ ) serve como instrumento de política monetária por ser mecanismo que possibilita ao Banco Central a atuação sobre o nível de liquidez da economia, comprando e vendendo títulos públicos da sua própria carteira o que enseja o ajuste do saldo de reservas bancárias das instituições financeiras.

Ao comprar os títulos, o Banco Central influencia a expansão da base monetária aumentando os meios do pagamento e, ao vender os títulos, a diminuição da quantidade de moeda (liquidez) no mercado.

Este mecanismo, conforme leciona De Chiara, oferece a celeridade indispensável ao crédito público e, concomitante mente possibilita a atuação direta do Estado pelos Bancos Centrais no fluxo da moeda e do crédito:

Oferencendo os títulos públicos no mercado financeiro a taxas atraentes ou recomprando-os em condições de compensadora liquidez para os respectivos detentores dos mesmos, obtém o Estado o resultado de aumentar ou diminuir o volume de dinheiro em circulação, ou, mesmo, de disciplinar a velocidade de circulação da moeda, injetando-a nas épocas próprias em que não há exagerada demanda de crédito, e retirando-o de circulação sempre que haja circunstância evidente de uma situação de utilização do crédito em formas propiciadoras de inflação monetária ${ }^{137}$.

Entretanto, este mecanismo também ajuda a financiar a dívida pública interna, tendo em vista que os títulos públicos nada mais são do que títulos emitidos pelo Estado a fim de captar dinheiro no mercado aberto.

Há, inclusive, neste ponto, uma questão sobre o financiamento do Tesouro diretamente pelo Banco Central, a qual será discutida no terceiro capítulo, oportunidade em que se analisará o caso do Banco Central do Brasil e, com mais profundidade, o funcionamento do open market.

\footnotetext{
${ }^{136}$ Denominação conferida pelo FED - que criou este mecanismo em 1920 - tendo em vista o fato de que esse mercado é acessível a todos, pessoas jurídicas não financeiras e pessoas físicas, inclusive.

${ }^{137}$ DE CHIARA, José Tadeu. Disciplina jurídica das instituições financeiras, cit., p. 292.
} 


\subsubsection{Taxa de Juros}

De maneira simples e objetiva, os juros podem ser definidos como o valor pago pelo tomador ao poupador pela disponibilidade de dinheiro, ou, melhor dizendo, o preço da renúncia à liquidez.

Deveria ser óbvio que a taxa de juros não pode ser um rendimento da poupança ou da espera como tal. Quando alguém acumula suas economias na forma de dinheiro líquido, não ganha juro, embora economize tanto quanto antes. Pelo contrário, a simples definição das taxas de juros diz-nos, literalmente, que ela é a recompensa pela renúncia à liquidez por um período determinado, pois a taxa de juros não é, em si, outra coisa senão o inverso da relação entre uma soma de dinheiro e o que se pode obter desistindo, por um período determinado, do poder de comando da moeda em troca de uma dívida ${ }^{138}$.

O controle da política monetária por meio da taxa de juros é, hoje, o meio mais frequentemente utilizado a fim de gerar expansão/contração da base monetária. O Banco Central, na qualidade de monopolista do mercado de reservas bancárias, pode gerenciar a liquidez de modo que o mercado resulte em escassez ou excesso de reservas.

No primeiro caso, os bancos buscarão recompor sua base monetária e para isso terão de buscar empréstimo no próprio Banco Central que, por sua vez, fixará determinada taxa de juros, para que eles possam obter financiamento e cobrir seus desequilíbrios de caixa - a famosa taxa de juros básica - que informa globalmente ao mercado qual a expressão da equivalência entre as disponibilidades monetárias e a preferência em manter a liquidez.

Essa taxa de juros básica influenciará os juros cobrados pelos bancos ao concederem créditos ao mercado, portanto, se for extremamente alta, dificultará a circulação dos meios de pagamento e acarretará maior custo de produção e, consequentemente, desaquecimento econômico.

Do ponto de vista do Estado, a administração das taxas de juros ganha especial destaque tanto no que se refere à função de controlar a moeda e o crédito, como no que diz respeito ao estímulo para implementar o investimento produtivo em setores considerados prioritários para a economia do país ${ }^{139}$.

\footnotetext{
${ }^{138}$ KEYNES, John Maynard. op. cit., p. 122.

${ }^{139}$ DE CHIARA, José Tadeu. Moeda e ordem jurídica, cit., p. 140.
} 
Todavia, essa ferramenta não tem sido utilizada adequadamente pelos governos. Especialmente no Brasil, a manutenção dos juros em patamares bastante altos tornou-se uma realidade deveras criticável e a necessidade de atender a meta inflacionária e a estabilidade da moeda têm sido utilizadas como justificativa.

Fernando Cardim de Carvalho ${ }^{140}$ destaca com precisão e simplicidade os efeitos nefastos que a adoção de uma política monetária apoiada por juros altos pode ocasionar. Esse mecanismo reduz o ritmo de crescimento de preços e, portanto, contém a inflação, justamente porque sufoca a demanda de mercado. Assim, a eficácia dessa política depende diretamente de sua capacidade de reduzir a demanda, contraindo a atividade produtiva e aumentando o desemprego.

Outro efeito danoso das altas taxas de juros decorre do fato de que, ao se transformar em instrumento corriqueiro da política monetária, "educa" os agentes econômicos já que o movimento de baixa de juros pode ser passageiro. Assim, os agentes, esperando sempre pelo aumento da taxa, tendem a se recusar a fazer empréstimos e aplicações a juros baixos por prazos mais longos. Ora, não há maneiras de financiar a retomada do investimento e do crescimento sem a possibilidade de tomar empréstimo por longo prazo.

Além disso, voltando ao caso brasileiro, a política de juros altos provoca efeito negativo sobre as finanças públicas. Como bem mais da metade da dívida pública federal está atrelada à taxa Selic ${ }^{141}$, mantê-la no nível extraordinariamente elevado em que está, estrangula ainda mais o setor público e sua capacidade de investimento.

Há ainda um reflexo negativo dessa política sobre a política cambial. As taxas de juros elevadas em relação ao resto do mundo (o Brasil tem uma das maiores taxas de juros do mundo) tendem a atrair capitais externos para nossa economia, especialmente aqueles voltados para a exploração de oportunidades de curto prazo (capital especulativo). Logo, a taxa de juros influencia diretamente a variação da taxa de câmbio. A vinda desses capitais valoriza a moeda e prejudica a balança comercial, ou seja, os produtos brasileiros voltados

\footnotetext{
${ }^{140}$ O CUSTO dos juros altos. Folha de S. Paulo, São Paulo, 23 jan. 2004. Seção Opinião Econômica.

${ }^{141}$ Sistema Especial de Liquidação e de Custódia - SELIC, do Banco Central do Brasil, é um sistema informatizado que se destina à custódia de títulos escriturais de emissão do Tesouro Nacional, bem como ao registro e à liquidação de operações com os referidos títulos. A taxa Selic é a taxa de juros média que incide sobre os financiamentos diários com prazo de um dia útil (overnight) lastreados por títulos públicos registrados no Sistema Especial de Liquidação e Custódia (Selic), ou seja, é a taxa de juros que equilibra o mercado de reservas bancárias. O Comitê de Política Monetária (Copom) estabelece a meta para a taxa Selic, e cabe à mesa de operações do mercado aberto do Banco Central manter a taxa Selic diária próxima à meta. Fonte: BANCO CENTRAL. Disponível em: <www.bancocentral.gov.br>.
} 
à exportação ficam mais caros e perdem mercados no exterior, enquanto no mercado interno os produtos importados ganham maior competitividade em relação aos produtos nacionais.

Neste ponto, em que se pretende somente analisar o mecanismo de execução da política monetária, não será feita uma análise mais aprofundada a respeito das consequências advindas da utilização exacerbada dessa ferramenta no manejo da política monetária. Esse tema será retomado no terceiro capítulo deste trabalho.

\subsection{Os Bancos Centrais e a Política Monetária - A visão doutrinária}

Conforme visto no capítulo anterior, inicialmente o Banco Central tinha como funções básicas controlar a circulação da moeda-papel, garantir a sua conversibilidade em ouro e financiar a atividades do Estado. Posteriormente, à medida que evoluía e assumia novas atribuições, o Banco Central inicialmente concebido como instituição comercial privada, passou a integrar o Estado como órgão público dotado de poderes para coordenar a atividade financeira.

Com a evolução e o aprimoramento das relações bancárias, as novas atribuições do Banco Central, atualmente consideradas típicas, podem ser assim enumeradas: gestão dos meios de pagamentos, ser o "banco dos bancos", efetuar o controle da moeda e do crédito, ser o prestamista de última instância e, mais recentemente, o regulador e o supervisor do sistema bancário.

Com tantas funções, todas elas conferindo ao Banco Central um papel preponderante no funcionamento do sistema bancário, levam à conclusão evidente de que esse Banco não pode ser administrado como qualquer outro banco comercial, pois, conforme destaca Eugênio Gudin, pelo fato de ser "Supridor de Moeda e regulador do crédito, ele há de ter precipuamente em vista o interesse coletivo" ${ }^{\text {142 }}$.

Nesse sentido, o Banco Central não deve concorrer com os outros bancos sob pena de, em tempos de crise, ser igualmente atingido não podendo assistir os demais adequadamente; não pode, além disso, visar à obtenção de lucro, pois, muitas vezes, para atender aos objetivos da política monetária deverá executar operações que acarretem

\footnotetext{
${ }^{142}$ GUDIN, Eugênio. op. cit., v. 1, p. 216.
} 
prejuízos. Por fim, para que atue de forma eficiente, o aspecto mais importante a ser observado é a sua relação com o Estado. Deve ele ser totalmente independente dos governos, funcionando como um quarto poder? Ou uma alternativa melhor seria mantê-lo como um órgão estatal hierarquicamente autônomo sob a égide do Poder Executivo e fiscalizado pelos demais Poderes, mas livre para desenvolver suas atividades?

Corroborando o entendimento sobre a premissa de que o Estado deve atuar na economia, nos termos das conclusões alcançadas no primeiro capítulo, este trabalho prestase a defender que a busca pelo pleno emprego e crescimento nunca deveriam ter sido substituídos pela estabilidade de preços: porque estabilidade de preços não é fim em si mesmo, não deve ser um objetivo, mas um meio para alcançar determinados fins e porque o Estado e seus organismos, entre eles o Banco Central, tem o dever de concentrar suas forças na busca pelo desenvolvimento social.

Com o objetivo de expor e refletir sobre o Banco Central atual e as questões que enfrenta em relação a sua atuação no que tange à política monetária e ao exercício de todas as suas funções, existe um claro ponto de partida, qual seja, se, como órgão pertencente ao Estado, deve ser dependente ou independente dos governos.

A atuação do Banco Central de forma mais ativa ou reativa passou a alternar-se de acordo com o tipo de regime adotado pelo governo ao qual pertencia e, também, pela fase histórica que atravessava ${ }^{143}$. Como foi possível observar no primeiro capítulo, foram muitas as fases e muitas as correntes doutrinárias orientadoras sobre a forma de condução da economia pelo Estado desde o século XIX até hoje.

Conforme destaca Novelli ${ }^{144}$, as ideias econômicas têm o poder de alterar a função das instituições e legitimar ou rejeitar a ação da burocracia e dos dirigentes de tais

\footnotetext{
${ }^{143} \mathrm{Na}$ década de 1970, por exemplo, em que ecoaram com grande profusão as ideias neoclássicas. O autor liberal Friedrich Hayek defendia que o Estado não deveria ter o monopólio de emissão da moeda ("deveria ocorrer a desestatização do dinheiro"), os bancos deveriam atuar livremente no mercado emitindo moedas, sem o controle hierárquico por parte de um Banco Central. Seu objetivo deveria restringir-se a deter as crises de inflação e de deflação. Segundo ele, o monopólio governamental sobre o dinheiro isenta o governo da necessidade de manter seus gastos dentro dos limites de sua renda o que provocaria as crises financeiras. Em seu sentido estritamente jurídico o "curso legal" significa apenas um tipo de dinheiro que um credor não pode recusar na liquidação de uma divida contraída na moeda emitida pelo governo. (...) $\mathrm{Na}$ medida em que o governo possua o monopólio da emissão de moeda e o empregue para estabelecer um tipo de dinheiro, provavelmente, também deve ter o poder de determinar por meio de que tipo de objetos podem ser liquidados débitos expressos por essa moeda. Mas isso não significa nem que todo dinheiro precise ser moeda de curso legal, nem mesmo que todos os objetos aos quais a lei dá atributos de moeda de curso legal precisem ser dinheiro. HAYEK, Friedrich A. A desestatização do dinheiro: uma análise da teoria e prática das medidas simultâneas, cit., p. 29.

${ }^{144}$ NOVELLI, José Marcos Nayme. Instituições, políticas e idéias econômicas: o caso do Banco Central do Brasil (1965-1998). São Paulo: Annablume; Fapesp, 2001. p. 31.
} 
instituições. Assim, o Banco Central, ao atravessar todas as etapas históricas que paulatinamente transformaram o Estado Moderno e suas instituições, adaptou-se às distintas realidades.

Também segundo esse autor, a relação entre os bancos centrais, as ideias econômicas e a política dependem de três fatores principais: (i) o papel reservado ao Estado pela filosofia política dominante do momento; (ii) os elementos conjunturais imediatos que influenciam as decisões dos governos: guerra, inflação, deflação, crise institucional, estado de calamidade etc. e, por fim, (iii) a complexidade/simplicidade das atividades delegadas ao Banco Central, ou seja, quanto mais simples e reduzidas as atividades, maior a possibilidade de que seja independente e não necessite de uma orientação específica.

Por exemplo, se o único objetivo do Banco Central, determinado em seu estatuto, for o de manter a inflação a uma taxa determinada, provavelmente seus burocratas vão trabalhar para atingi-la, devendo prestar contas se não alcançarem seu objetivo. Todavia, se o objetivo da atuação do Banco Central estiver voltado a executar a política monetária para elevar o nível de emprego, expandir e direcionar o crédito e promover o desenvolvimento equilibrado da nação, nesse caso, muito provavelmente suas metas dependerão muito mais da atuação coordenada com as outras políticas do governo - o que seria o ideal.

Do exposto, verifica-se que a função principal do Banco Central consolidou-se como sendo a "manutenção do valor da moeda", todavia, ao longo do tempo tal função obteve, ao menos, três diferentes significados: a) garantir a convertibilidade da moeda em ouro; b) buscar o pleno emprego crescimento e c) assegurar a estabilidade de preços.

Com efeito, durante o século XIX até a eclosão da Primeira Guerra Mundial, os bancos centrais seguiam o laissez-faire, estavam adstritos a converter a moeda em ouro; sua atividade era, portanto, mais independente, tendo em vista o fato de que tinham uma meta objetiva e claramente definida e deveriam usar de todos os mecanismos possíveis para cumpri-la, em detrimento, inclusive, de outras prioridades eventualmente existentes.

Posteriormente, do Pós-Primeira Guerra até 1970, os Bancos Centrais assumiram tarefas mais complexas e passaram a subordinar-se ao controle do Estado, tornando-se, portanto, mais dependentes. Na sequência, com o advento do Estado Neoliberal, volta a surgir uma onda de defensores da independência dos bancos centrais, obstinados a assumir uma única função, a estabilidade de preços. 


\subsubsection{Estabilidade de Preços como objeto da Política monetária}

Essa questão deu origem a acaloradas discussões nas academias ao redor do mundo, tendo sido o ponto de partida as ideias do economista liberal Milton Friedman a respeito das causas da inflação e sobre os meios de combatê-la. Vale lembrar que a inflação foi, especialmente nas décadas de 1970, 1980 e 1990, considerada problema crônico enfrentado pelas economias de grande parte dos países do globo. Assim, toda solução apresentada nesse período para o seu combate era ouvida e acatada com grande entusiasmo. Nesse caso não foi diferente.

De acordo com Friedman, a inflação somente passou a ser um problema crônico e incontrolável a partir da difusão do uso do papel moeda, especificamente por ser um tipo de moeda passível de ser produzido indefinidamente a um custo insignificante, bastando “imprimir números mais altos nos mesmos pedaços de papel” com base em um decisão subjetiva daquele que estiver no poder.

Defende o autor que na época em que se utilizava o metal, por inferior que fosse a sua qualidade, havia um custo para sua cunhagem e isso restringia a produção de moeda. Superada essa restrição, o único limite para a emissão de mais moeda passou a ser o controle do Banco Central. A inflação, por ser um fenômeno exclusivamente monetário, no entender de Friedman, ocorreria nas situações em que a quantidade de moeda emitida fosse maior do que a produção: quanto mais rápido o aumento da quantidade de moeda por unidade de produção, mais alta a taxa de inflação.

Segundo Friedman, "no mundo moderno, a inflação é um problema de impressora", um "fenômeno monetário" que aumenta proporcionalmente à quantidade de moeda emitida e despejada no mercado para financiamento das atividades dos governos que, ao procederem assim, podem investir e custear seus projetos sem enfrentar os trâmites nada populares de aumento de impostos, ou tomada de empréstimos do público.

Existe uma assimetria que revela uma tendência da política de governo na direção de adotar objetivos indevidamente ambiciosos de pleno emprego. Qualquer medida que possa ser representada como favorável ao aumento do emprego é politicamente atraente. Qualquer medida que possa ser representada como provocadora do aumento do desemprego é politicamente sem atrativos. A relação entre emprego e inflação é dupla. Primeiro, as despesas do governo podem ser descritas como favoráveis ao aumento do nível de emprego, os impostos do governo, como promotores o do aumento do desemprego ao reduzirem o dispêndio privado. Por 
conseguinte, a política do pleno emprego reforça a tendência de o governo aumentar o dispêndio sem aumentar imposto, ou mesmo enquanto reduz os impostos, e financiar qualquer déficit daí resultante com um aumento da quantidade de moeda. (...) A pressão para promover o pleno emprego tem dado à política monetária do FED a mesma tendência inflacionária que deu à política fiscal do governo. Essas políticas não têm conseguido produzir o pleno emprego, mas têm produzido inflação. ${ }^{145}$

Com base na teoria sobre a inflação ser o fenômeno exclusivamente monetário, e sobre a responsabilidade total dos governos quanto a sua ocorrência, surgiu a ideia de que o Banco Central e o controle sobre a política monetária deveriam ser independentes dos governos, deveriam atuar de forma discricionária. Assim, seria possível manter um patamar mínimo de inflação evitando-se o contágio da política monetária voltada para a estabilidade por interesses políticos.

Todavia, como se sabe, a moeda não é neutra e sua emissão não gera automaticamente a inflação ${ }^{146}$. Conforme leciona Eugênio Gudin, numa sociedade dinâmica a teoria da neutralidade da moeda é inconcebível, pois o incremento dos fatores de produção e da produção em si deve ser acompanhado por um suprimento monetário capaz de impedir uma queda continuada de preços.

Apenas como ilustração, considerem-se os períodos de prosperidade em que há ampla expansão do crédito: empresas consolidadas aumentam seu nível de produção, novas empresas buscam crédito para investir em inovação, diferenciando-se daquelas que já possuem marca consolidada no mercado. Os consumidores, por sua vez, dotados de alta liquidez passam a gastar como se o aumento de suas rendas fosse eterno e os produtores, de seu lado, aumentam seus estoques sempre com a expectativa de aumento da procura dos consumidores por seus produtos.

Em tempos de crise deixa-se de inovar, o que se reflete no interesse dos consumidores que deixam de adquirir os produtos; em crise, as empresas demitem seus empregados os quais tem seu poder de compra drasticamente reduzido, e o sistema, pela redução de liquidez, entra em depressão. Assim, diferentemente do que apregoam os

\footnotetext{
${ }^{145}$ FRIEDMAN, Milton. O poder e o dinheiro: episódios da história monetária, cit., p. 194. O economista era ardoroso crítico do FED, para o qual propunha, pura e simplesmente, a extinção.

146“'O simples aumento de meios de pagamento não constitui inflação, mas provoca alta dos preços, seja por haver fatores de produção desempregados, seja porque a velocidade média da circulação da moeda tenha baixado, seja por uma expectativa desfavorável de indivíduos e homens de negócios quanto aos preços e aos lucros”. GUDIN, Eugênio. op. cit., v. 1, p. 174.
} 
monetaristas, a moeda não é neutra; ao contrário, a administração adequada de sua disponibilidade monetária contribui, no curto prazo, para a superação de momentos de crise e, no longo prazo, influi no processo de desenvolvimento dos países.

Cabe destacar, no entanto, que Friedman ${ }^{147}$ nunca defendeu que a estrutura ideal para a manutenção da estabilidade monetária seria a de um banco central independente. Para ele, deixar as decisões sobre política monetária a cargo exclusivamente das autoridades monetárias também poderia representar um risco e o melhor seria o estabelecimento de metas quantitativas, por meio de normas, a serem seguidas pelos Bancos Centrais e fiscalizadas pela sociedade. Assim, os bancos centrais seriam meros órgãos técnicos, cumpridores das metas preestabelecidas, sem poderes discricionários:

"A Grande Depressão nos Estados Unidos, longe de ser um sinal da instabilidade inerente do sistema de empresa privada, constitui testemunho de quanto mal pode ser feito por erros de um pequeno grupo de homens - quando dispõem de poderes vastos sobre o sistema monetário de um país. É possível que estes erros possam ser desculpados na base do conhecimento disponível naquela ocasião - embora eu ache que não. Mas, este não é realmente o ponto. Qualquer sistema que dê tanto poder a um grupo de homens cujos erros - compreensíveis ou não podem ter efeitos tão severos e amplos é um mau sistema. É um mau sistema para os que acreditam na liberdade justamente porque dá a poucos homens um poder tão grande sem que seja exercido nenhum controle efetivo pelo corpo político - este é o argumento-chave político contra um Banco Central 'independente'. Mas é um mau sistema, mesmo para os que põem a segurança acima da liberdade. Erros, compreensíveis ou não, não podem ser evitados em sistemas que dispensam a responsabilidade, mas dão poderes amplos a um pequeno grupo de homens e, portanto, tornam ações políticas importantes altamente dependentes de acidentes de personalidade. Parafraseando Clemenceau, dinheiro é coisa importante demais para ser deixado aos bancos centrais." $" 148$

Embora Friedman nunca tenha concordado com a ideia de um banco central independente, foram suas proposições quanto ao controle da inflação por meio do estabelecimento de metas fixas as fontes de inspiração de seus principais defensores, pois, como forma de possibilitar o cumprimento de tais metas, o Banco Central deveria ser

\footnotetext{
${ }^{147 ،}$ “Um dos maiores opositores a esta independência, por considerá-la causadora de algumas sérias dificuldades à execução da política econômica norte-americana, é o Professor Milton Friedman (Universidade de Chicago). Friedman entende que o mandato dos Governadores deve coincidir com o do Presidente da República e que o Sistema de Reserva não deve constituir 'um poder independente do governo', como um quarto poder além do Executivo, do Legislativo e do Judiciário. O problema monetário faz parte integrante da política econômica e financeira do governo. Não é inamissível, pensa Friedman, que a orientação dos Governadores do Sistema de Reserva Federal colida com a do Presidente e a do Secretário do Tesouro". GUDIN, Eugênio. op. cit., v. 1, p. 272.

${ }^{148}$ FRIEDMAN, Milton. Capitalismo e liberdade, cit., p. 51.
} 
isolado e autônomo de forma que pudesse atuar sem a interferência do Poder Executivo. A seguir, será possível observar de que forma tema vem sendo tratado.

\subsubsection{A questão da Autonomia dos Bancos Centrais}

De acordo com a classificação de Rosa Maria Lastra ${ }^{149}$, os Bancos Centrais podem ser dependentes, independentes ou autônomos. Essa autora entende que tais instituições devem gozar de independência em relação aos objetivos traçados pelos governos durante seus mandatos, o que seria "uma despolitização parcial do processo de produção de moeda", mas que, por sua vez, os Bancos Centrais deveriam, na qualidade de órgãos estatais, estar comprometidos com o cumprimento de metas previamente estabelecidas por meio de instrumentos formalmente definidos pelo Estado.

Corroborando seu argumento, menciona alguns bancos centrais formalmente independentes que adotaram maneiras distintas de se relacionar com os governos: na Nova Zelândia, o objetivo de estabilidade de preços é definido de forma rígida, com um alvo numérico imposto; na Alemanha ${ }^{150}$, esse objetivo é fixado de forma mais ampla: o Banco Central teria o dever legal de garantir o valor da moeda e seria livre para garanti-lo utilizando-se dos métodos que entendesse mais adequados e, por fim, cita como exemplo o Federal Reserve System nos Estados Unidos, que possui uma variedade de objetivos predeterminados em seu estatuto de constituição, quais sejam: a estabilidade de preços, crescimento econômico e emprego, devendo estabelecer livremente quais critérios seguirá para atingi-los.

Nesse sentido, a independência dos Bancos Centrais, no entender de Rosa Maria Lastra, não estaria ligada aos objetivos a serem cumpridos pelo Estado já que estes são estabelecidos por normas de acordo com os ditames do Estado ao qual cada banco central

\footnotetext{
${ }^{149}$ No exercício de suas responsabilidades um banco central pode ser dependente, autônomo ou independente das autoridades políticas. A "dependência" implica na subordinação ás ordens do Executivo. A "autonomia" (etimologicamente significando habilidade de criar regras para si mesmo) envolve a liberdade operacional na condução das funções. A "independência" indica uma ausência de interferência política e traz o mais amplo campo de manobra na conduta das políticas delegadas ao Banco Central. Frequentemente, entretanto, os vocábulos independência e autonomia são utilizados sem distinção. LASTRA, Rosa María. Central banking and banking regulation. Tradução de Dan Makus Kraft. Belo Horizonte: Del Rey, 2000. p. 22.

${ }^{150}$ Destaque-se que, atualmente, o Banco Central da Alemanha está inserido em uma estrutura distinta na qual deve observar o Banco Central Europeu, instituição supranacional que define as diretrizes econômicas de União Europeia.
} 
pertence, mas, sim, à liberdade que essas instituições teriam ao atuar para alcançar tais objetivos.

Como Bancos Centrais Independentes raramente podem escolher seus focos, a discussão é essencialmente focada no limite de poderes delegados aos bancos centrais para que cumpram seu objetivo legal ${ }^{151}$.

Quanto aos objetivos a serem seguidos pelas políticas monetárias dos países, pelo fato de a experiência prática demonstrar que existe a manipulação da política monetária para fins políticos de curto prazo, voltada ao atendimento de expectativas imediatas de determinados grupos de interesse, Lastra defende que a estabilidade monetária deve ser um consenso, endossado por diferentes partidos políticos para que, assim, não existam divergências quanto a sua prioridade, independentemente dos políticos que assumirem o poder.

A autora destaca, ainda, que, se fosse independente, o Banco Central estaria livre das pressões políticas, especialmente no período próximo às eleições em que os políticos, a fim de elegerem seus sucessores, determinam a implantação de uma política expansionista, com baixas taxas de juros e redução do desemprego, e, logo após as eleições, sujeitam a nação a grandes sacrifícios pelo estabelecimento de política contracionista a fim de conter a inflação.

No Brasil, Eugênio Gudin, nos idos da década de 1970, posicionou-se sobre a questão da independência:

O princípio dominante é de que o Banco Central deve guardar certo grau de independência do Governo, não só para tirar-lhe o caráter de repartição burocrática, como para abrigá-lo de uma influência excessiva dos políticos da hora. Isto tem, além dos mais, a vantagem de dissociar o crédito do Banco, do crédito do Estado. (...) Para assegurar ao Banco uma relativa independência do Governo, é freqüente submeterem-se ao "placet" do Senado as nomeações dos diretores, bem como estipular mandatos bastante longos e irrevogáveis pelo Executivo, salvo nos casos excepcionais. ${ }^{152}$

O professor Haroldo Malheiros Duclerc Verçosa pontua que a grande dificuldade para a caracterização de um banco central autônomo estaria em determinar quais são os seus objetivos prioritários e se são condizentes com os objetivos perseguidos pelo Estado.

\footnotetext{
${ }^{151}$ LASTRA, Rosa María. op. cit., p. 23.

${ }^{152}$ GUDIN, Eugênio. op. cit., v. 1, p. 217.
} 
Ainda assim, o autor apresenta posição favorável ao estabelecimento de um banco central forte e totalmente autônomo.

$\mathrm{Na}$ verdade, em nossa opinião, não quebra o princípio democrático a existência de um banco central forte não subordinado nem sequer instrumentalmente a outro órgão do governo no qual repouse conjuntamente a competência para a formulação e a execução da política monetária, desde que esteja sujeito a controles institucionais adequados, embora certamente mais complexos do ponto de vista políticoconstitucional ${ }^{153}$.

Verçosa destaca que o Banco Central independente ${ }^{154}$ estaria imune ao financiamento dos déficits orçamentários, ao contrário do Banco Central subordinado aos ditames dos políticos da vez (seja por meio de emissão de títulos da dívida pública, seja por outras formas de concessão de crédito ao estado).

Alan Blinder ${ }^{155}$, macroeconomista, professor da Universidade de Princeton e exvice-presidente do Federal Reserve System, defende um banco central funcionalmente independente. Entende que os rumos da economia devem ser traçados, no Estado de Direito, por seus dirigentes. Todavia, em sua opinião, a escolha dos meios utilizados para atingir tais metas deve ser delegada aos técnicos do Banco Central ${ }^{156}$.

Trata-se de uma posição intermediária na qual os governos definem os objetivos da política monetária, sendo, portanto negada aos tecnocratas a autonomia política, e relegando-lhes apenas a autonomia técnica.

Argumenta que as políticas estabelecidas em longo prazo tendem a não gerar efeitos imediatos sobre a produção e a inflação, o que pode ocasionar a perda de

\footnotetext{
${ }^{153}$ VERÇOSA, Haroldo Malheiros Duclerc. Bancos centrais no direito comparado: o Sistema Financeiro Nacional e o Banco Central do Brasil. São Paulo: Malheiros, 2005. p. 87.

${ }^{154}$ Cumpre esclarecer que, embora os termos autonomia e independência sejam utilizados recorrentemente como sinônimos, eles têm significados distintos, stricto sensu o banco central independente teria uma estrutura muito peculiar, na qual não existiria submissão a qualquer outro órgão estatal. Pelo grau de liberdade e prerrogativas concedidas, o modelo prejudicaria inclusive a formulação do Estado de Direito, que, por concepção, é dotado de somente três poderes em igual nível hierárquico e interdependentes. O banco central independente tenciona ser "um quarto poder" atuando de forma paralela aos demais poderes, podendo inclusive não estar alinhado de forma harmônica com o Poder Executivo no que tange ao desenvolvimento da política econômica. Não haveria, sobre este modelo de banco central, a interferência e o controle de qualquer órgão externo.

${ }^{155}$ BLINDER, Alan S. Bancos centrais: teoria e prática. Trad. Maria Abramo Caldeira Brant. São Paulo: Ed. 34, 2000.

${ }^{156}$ Deve-se atentar para o fato de que as metas definidas pelos dirigentes do Estado devem ser claras e precisas, pois, do contrário, se as metas forem muito abrangentes ou abstratas, a tarefa de definição dos rumos da política monetária caberá aos técnicos do banco central que deverá interpretá-las.
} 
popularidade dos governantes que, por esse motivo, tendem a preferir soluções ágeis (talvez não tão eficientes) e que gerem efeito em curto prazo.

No caso de um Banco Central dependente, esse seria motivo suficiente para o abandono da política de longo prazo consistente. O que não ocorreria num Banco Central independente. Segundo Blinder a independência possibilita, portanto, a implantação de uma política monetária de longo prazo que permita garantir o alcance de determinadas metas impostas pelo Estado.

De acordo com o conceito de banco central independente de Blinder, deve ser criado um procedimento que dificulte a alteração/revogação dos atos dos funcionários do banco central pelo chefe do Poder Executivo ou por outro órgão hierarquicamente superior. Isso confere liberdade de ação dos bancos centrais no alcance de suas metas e evita a revogação de atos que não agradam aos interesses políticos dominantes.

Blinder, por fim, pondera, ainda sobre a independência dos bancos centrais, que a liberdade de agir deve implicar necessariamente a obrigação de explicar-se para a população.

Se o banco central toma boas decisões não deveria ter problemas em explicá-las e defendê-las em público. Se não pode articular um raciocínio coerente para suas ações, talvez suas decisões não sejam tão boas quanto pensa $^{157}$.

Menciona como exemplo o "Reserve Bank of Australia Bulletin"158 que esclarece publicamente, inclusive divulgando na rede mundial de computadores, mês a mês, as medidas tomadas pelo Banco Central australiano. O Federal Reserve, por sua vez, bastante elogiado pelo fato de, desde o início de 1994, emitir relatórios imediatamente após as reuniões do Federal Open Market Committee, na opinião de Blinder, não é suficientemente claro em suas declarações que costumam ser excessivamente concisas.

A esse respeito vale mencionar que o Banco Central do Brasil, por sua vez, divulga mensalmente, na rede mundial de computadores, as atas do COPOM (Comitê de Política Monetária). O tema será objeto de análise no capítulo seguinte.

\footnotetext{
${ }^{157}$ BLINDER, Alan S. op. cit., p. 87.

${ }^{158}$ RESERVE BANK OF AUTRALIA. Disponível em: <http://www.rba.gov.au/PublicationsAndResearch/Bulletin/2009/index.html>. Acesso em: 03 abr. 2009.
} 
Os cientistas políticos de convicções liberais, Sola, Garman e Marques ${ }^{159}$, defendem que as democracias latino-americanas, somente com a conquista da estabilidade monetária conseguiram consolidar suas instituições democráticas e almejar um patamar social melhor. O Banco Central conquistou, a partir de então, o status de autoridade monetária autônoma. Assim, pretendem demonstrar que a estabilidade de preços levou à reforma do conjunto de instituições que definem o poder do Banco Central - e não o contrário, como defende a maioria dos economistas que estudam o tema.

O saber convencional, de acordo com os mencionados autores, estipula a independência do banco central em relação à arena política como precondição da estabilidade de preços. Conforme essa visão, a condição de longo prazo para reforçar o compromisso da economia com a estabilidade de preços consiste em delegar autoridade monetária a um banco central independente da arena política.

De acordo com os cientistas políticos mencionados, a autonomia dos bancos centrais é resultado de um fenômeno social em que se verifica a necessidade de um controle e preservação de certas conquistas econômicas necessárias à sociedade e que somente poderiam ser garantidas com poderes independentes.

Utilizam o caso do Banco Central do Brasil e da estabilização monetária decorrente da implantação do Plano Real, para destacar que tais conquistas somente foram possíveis a partir do momento em que a sociedade brasileira percebeu a "estabilidade de preços como bem público de primeira ordem"160.

Utilizam, ainda, o exemplo da Alemanha em que o Bundesbank alcançou o bom desempenho verificado nos últimos 40 anos como instituição autônoma, em razão do efeito devastador da hiperinflação sobre a vida de milhões de alemães durante a década de 1920. Isso porque, após a experiência traumática da alta inflação monetária verificada na Alemanha no período, passou a haver um consenso social sobre a necessidade de manter a moeda estável.

\footnotetext{
${ }^{159} \mathrm{O}$ liberalismo econômico dá por certo três pressupostos. Primeiro, a estabilidade de preços é um bem público. Segundo, a inflação é mais prejudicial aos setores sociais menos equipados para defender-se contra o imposto inflacionário, sendo assim a estabilização econômica é condição de maior equidade em longo prazo. Terceiro, a independência do banco central é a condição principal para que os atores e instituições responsáveis pela estabilidade de preços atuem em benefício da sociedade. SOLA, Lourdes; KUGELMAS, Eduardo; GARMAN, Cristopher; MARQUES, Moisés. Banco Central, autoridade política e governabilidade democrática. SOLA, Lourdes; KUGELMAS, Eduardo; WHITEHEAD, Laurence. Banco Central: autoridade política e democratização: um equilíbrio delicado. Rio de Janeiro: FGV, 2002. p. 121.

${ }^{160}$ Id. Ibid., p. 156.
} 
Com efeito, para defender a ideia de Banco Central autônomo ou independente (pois a maioria dos autores utiliza esses vocábulos como sinônimos, embora não o sejam) são utilizados os argumentos em relação à necessária neutralidade de uma instituição não subjugada aos interesses dos políticos que ocupam o governo. Entendem tais autores que a busca e a manutenção da estabilidade da moeda e de reduzidos patamares de inflação representam os objetivos legítimos de política monetária para conferir autonomia aos bancos centrais.

Nesse sentido, os banqueiros centrais teriam muito mais interesse em perseguir a estabilidade monetária do que os políticos, dado que muitas vezes as medidas a serem tomadas podem ser impopulares, tais como priorizar a estabilidade monetária em contrapartida à manutenção de empregos. Nesse sentido, os bancos centrais, no entender dos defensores da independência, deverão adotar políticas recessivas e de contração monetária, como parte de seu combate à inflação.

Assim, um banco central autônomo teria o condão de perseguir apenas algumas políticas predefinidas as quais poderiam ser muito diferentes daquelas preferidas pelos titulares do poder. Nesse sentido, os índices menores de inflação nos países que adotam a estrutura de banco central independente seriam decorrência direta do fato de que os banqueiros centrais quase sempre optam por práticas mais restritivas do que as políticas desejadas pelo Poder Executivo.

Seriam, adicionalmente, argumentos usualmente utilizados como favoráveis à autonomia do banco central: a maior estabilidade macroeconômica devido à impossibilidade de que os governos se utilizem da emissão monetária como meio de financiamento, garantindo, consequentemente, uma baixa taxa de inflação; alcance, pelo poder executivo, de uma política fiscal equilibrada em consequência do fato de não mais serem financiados pelos Bancos Centrais, ou seja, os governos passariam a financiar suas atividades com base na arrecadação de impostos e emissão de títulos de dívida pública.

José Antonio Avelãs Nunes ${ }^{161}$, em artigo publicado sobre o tema, está no grupo de autores que utiliza os vocábulos 'autonomia' e 'independência' como sinônimos. Diferentemente do que pensam os autores aqui citados, ele entende que a concepção de um banco central independente não implica dizer que ele será adepto das "teses monetaristas segundo as quais a política monetária e a atuação dos bancos centrais enquanto autoridades

\footnotetext{
${ }^{161}$ NUNES, António José Avelãs. Nota sobre a independência dos Bancos Centrais. Revista de Direito Mercantil Industrial, Econômico e Financeiro, São Paulo, v. 103, p. 59, 1996.
} 
monetárias devem ter como objectivo único a estabilidade de preços". Pois, se esse modelo monetarista proposto por Friedman ${ }^{162}$ fosse o conceito ideal a ser adotado, o efeito seria contrário, vale dizer, o banco central não seria uma autoridade monetária independente e, sim, um mero "organismo de execução mecânica da regra" sem qualquer poder discricionário de decisão.

Nunes pontua que, em regra, os países monetaristas (que consideram a estabilidade da moeda o objetivo principal) geralmente possuem bancos centrais independentes, como é o caso do Deutsche Bundesbank ${ }^{163}$, mas que não é esse o fator determinante de seu sucesso, devendo ser utilizado como modelo por todos os países.

Em regra, autores (ou países) que atribuem à estabilidade monetária uma importância maior do que aos outros objectivos da política são levados a defender maior grau de independência do banco central enquanto autoridade monetária (...). Esta opção pode ter alguma lógica em países industrializados desenvolvidos, económica e politicamente estabilizados. Mas parece dificilmente aceitável em países que têm no desenvolvimento económico o principal problema a resolver (nos quais, em regra, a administração fiscal é deficiente e o mercado monetário e o mercado financeiro não existem ou não funcionam), bem como em países com situações difíceis no domínio do emprego e da balança de pagamentos. Nestes últimos casos, parece desejável que o banco central, enquanto autoridade monetária, não possa alhear-se da situação econômica e social do país, erigindo a estabilidade monetária em objectivo primordial de sua acção, ao qual deverão sacrificar-se, friamente, os outros objetivos da política econômica"164.

Para Nunes, um banco central independente não deve ser mero cumpridor de regras, mas deve gozar de poder discricionário no exercício de suas competências. Ele resume nestas características o modelo de banco central independente: que ele possa recusar-se a financiar a dívida do Estado, possa escolher livremente não só as medidas de política monetária, mas também a oportunidade e os níveis de intervenção na economia. Todavia

\footnotetext{
${ }^{162}$ A teoria monetarista capitaneada por Friedman e acima exposta defende a priorização das metas quantitativas que especificam patamares máximos que podem ser atingidos pela inflação sem isso implicar prejuízos consideráveis para a economia. O cumprimento das metas de inflação torna-se, a partir de então, a ideia fixa dos formuladores da política monetária. Os monetaristas entendem que os governos deveriam ocupar-se da economia real enquanto o banco central com absoluta independência, apoiado na política monetária, deveria incumbir-se exclusivamente de buscar a estabilidade de preços pelo controle da oferta da moeda.

163“"Comme pour couronner la restauration de son appareil économique et financier, l'Allemagne se dote d'un nouvelle banque d'emission, la Bundesbank. Elle naît en 1957, et prend la suite de la Banque des Pays Allemandes. Comme elle, elle a son siège à Franc-fort. Mieux qu'elle, indépendante du gouvernement, elle est armée pour regler, selon les techniques modernes, le volume de la monnaie et du crédit. L'emission n'est subordonnée à aucune règle de courverture: ni plafond, ni proportion minimale." SEDILLOT, René. op. cit., p. 126.

${ }^{164}$ NUNES, António José Avelãs. Nota sobre a independência dos Bancos Centrais, cit., p. 64.
} 
Nunes pondera que este não seria um objetivo adequado para aqueles países menos desenvolvidos os quais possuem outros objetivos a perseguir.

Mas cremos que não tem fundamento a tese dos que pretendem que a noção de independência dos bancos centrais só faz sentido a partir do reconhecimento de que a inflação é essencialmente um fenômeno monetário e de que é o único objectivo da política monetária prosseguir sem qualquer consideração pelos outros objectivos políticos do estado ${ }^{165}$.

Assim, resumidamente se pode concluir que, para Avelãs Nunes, os Bancos Centrais podem ser independentes, desde que atuem de acordo com as necessidades econômicas e sociais de seus países sem adotar metas puramente e alheias à realidade apenas com o objetivo de alcançar a estabilidade da moeda quando outros problemas mais graves possam existir.

Novaes de Almeida ${ }^{166}$ analisa a questão da independência do banco central com base em casos concretos que se subdividem em dois grupos distintos - aqueles que deram certo e aqueles que não deram certo. No primeiro grupo estão os Bancos Centrais da Alemanha, Dinamarca, Estados Unidos e Suíça, já no segundo grupo estão Canadá, Itália, Venezuela, Argentina e Brasil, concluindo que, para as duas vertentes, há casos de sucesso e insucesso independentemente da escolha que se tenha feito.

Esse autor entende que, para se avaliar a possibilidade de o modelo de Banco Central independente funcionar, deve-se analisar o grau de evolução e eficiência alcançado pelo sistema financeiro do país, da existência de um sistema efetivamente democrático e da preparação do próprio Banco Central para tanto. Portanto, dependeria a eficiência dessa de uma série de outros fatores inerentes às peculiaridades de cada nação.

Analisados alguns argumentos favoráveis e outros contra a independência dos Bancos Centrais, a primeira questão a ser debatida no que tange aos argumentos de defesa de um Banco Central independente consiste na premissa de que o Poder Executivo atua sempre de maneira "irresponsável”, criando enormes déficits, financiando suas dívidas com a emissão de moedas e gerando inflação. Esse seria um dos principais motivos para a “despolitização" da política monetária (contradição em termos!) e para o afastamento do banco central da administração.

\footnotetext{
${ }^{165}$ NUNES, António José Avelãs. Nota sobre a independência dos Bancos Centrais, cit., p. 60.

166“Por independência entende-s a possibilidade d adoção de política oposta à dos tesouros nacionais e mandatos de prazo fixo para as suas diretorias. ALMEIDA. José Roberto Novaes de. op. cit., p. 150.
} 


\begin{abstract}
A independência do Banco Central como condição para a manutenção do poder de compra da moeda parece ser a panacéia dos anos 90 , como a adoção de regras quantitativas foi no anos 70 e 80 . Muitos aderem à proposta e repetem-na pela imprensa, como a receita "científica" para se obter a disciplina monetária. Propõe-se que bancos centrais são instituições definidas com uma função natural: garantir a estabilidade do poder de compra da moeda. Assume-se que pressões políticas, no entanto, tendem a desviar a autoridade monetária de sua função natural, subordinando de modo não apenas ilegítimo como também ineficaz ordenação monetária a objetivos de curto prazo, como a sustentação do nível de emprego ou a promoção do crescimento que governos irresponsáveis acreditariam obter através de políticas expansionistas. $\mathrm{O}$ sistema monetário seria, assim, algo sério demais para ser deixado aos políticos. A independência do Banco Central asseguraria que a gestão monetária seria exercida acima dos jogos políticos ${ }^{167}$.
\end{abstract}

Os políticos tenderiam a "criar condições econômicas favoráveis" de forma artificial no país um pouco antes das eleições o que os tornaria mais populares e, em consequência, capazes de reeleger-se ou eleger seus candidatos, argumento que também se funda na falta de comprometimento e idoneidade dos governos os quais adotam as chamadas medidas populistas.

Há argumentos hábeis a contestar esses pontos, como base nos alicerces do próprio Estado de Direito. A divisão de poderes é um princípio geral do Direito Constitucional tão antigo quanto Aristóteles, tão consagrado quanto Locke e Rousseau. A sociedade organizou-se de uma forma tal que conferiu aos Poderes Executivo, Legislativo e Judiciário as ferramentas necessárias para a organização da vida em comunhão.

O governo é, então, o conjunto de órgãos mediante os quais a vontade do Estado é formulada, expressada e realizada, ou conjunto de órgãos supremos a quem incumbe o exercício das funções do poder político. Este se manifesta mediante suas funções que são exercidas e cumpridas pelos órgãos de governo. Vale dizer, portanto, que o poder político uno, indivisível e indelegável se desdobra em várias funções fato que permite falar em distinção de funções, que fundamentalmente são três: a legislativa, a executiva e a jurisdicional ${ }^{168}$.

A confiança delegada aos três poderes é o verdadeiro pilar de todo o Estado de Direito. Nas palavras de José Afonso da Silva, trata-se de uma forma de organização jurídica das manifestações de poder

\footnotetext{
${ }^{167}$ CARVALHO, Fernando J. Cardim. A independência do Banco Central e a disciplina monetária: observações céticas. Revista de Economia Política, v. 15, n. 4, p. 135, out./dez. 2005.

${ }^{168}$ SILVA, José Afonso da. Curso de direito constitucional positivo. 19. ed. São Paulo: Malheiros, 2000. p. 113.
} 
Questionar a legitimidade de um desses Poderes para o exercício de suas atribuições esvaziando-as sob a justificativa de que não possui competência para conduzila de forma hígida e eficiente, consiste, portanto, em questionar os fundamentos do Estado de Direito.

Sobre isso destaca Fernando J. Cardim de Carvalho ${ }^{169}$ que, se o Estado não possui competência para o exercício da política monetária, também não a terá para qualquer outra atividade que envolva a política econômica e a gestão das finanças públicas:

$\mathrm{Na}$ verdade, podemos perguntar se uma sociedade incapaz de decidir sobre a gestão de sua moeda seria capaz de gerir suas finanças públicas, seu mercado cambial, suas relações comerciais com o exterior, ou, de fato, qualquer questão econômica para a qual alguém possa definir leis naturais e mecanismos inelutáveis.

Não se quer aqui negar o fato de que possa existir má condução da política monetária (o autor acima pontua que "processos políticos normais são irremediavelmente marcados pela corrupção ou pelo oportunismo"), pois isso se verificou em diversos países e em diversos momentos históricos da humanidade. Mas a solução adequada nesse caso seria repensar a eficácia dos controles sobre atividade do Poder Executivo, a eficiência do mecanismo de "freios e contrapesos", até porque a política econômica dos países geralmente está normatizada, sendo fácil aos demais Poderes fiscalizar/exigir sua observância. O que não se pode é simplesmente privar o Estado de um mecanismo hábil a controlar e organizar a vida econômica do país, em razão da suposta ineficiência do Poder Executivo em conduzi-lo.

Poder é a capacidade de mobilizar forças econômicas, sociais ou políticas para obter um certo resultado, que pode ser medido pela probabilidade de esse resultado ser conseguido diante dos diversos tipos de obstáculo ou oposição enfrentados ${ }^{170}$. Os Três Poderes do Estado estão imbuídos de mecanismos legítimos capazes de mobilizar forças para atingir seus fins.

A concepção de um Banco Central desvinculado do contexto social e da hierarquia de poderes e atrelado a uma meta econômica estabelecida por um corpo de técnicos que não levam em conta os aspectos conjunturais da economia real não tem sentido. Esse

\footnotetext{
${ }^{169}$ CARVALHO, Fernando J. Cardim. op. cit., p. 136.

${ }^{170}$ BLACKBURN, Simon. op. cit., p. 301.
} 
Banco Central não alcança o mesmo status de Poder legitimado pelo povo e não é capaz de, sozinho, atingir quaisquer resultados condizentes com o que se espera dele.

Utilizando, novamente, a lição de José Afonso da Silva, o poder político é uma energia capaz de coordenar e impor decisões visando à realização de determinados fins. No contexto ora analisado, este poder está nas mãos do Estado e mais concretamente, na Constituição do país, pois lá estão definidos os fins do Estado, inclusive, mas não só em relação à política monetária.

Nas palavras de Fernando J. Cardim de Carvalho ${ }^{171}$ :

A tese da independência é, assim, uma posição fundamentalmente derrotista, seja porque supõe que a estabilidade seja algo a se forçar garganta abaixo, seja porque se imagine que processos democráticos são intrinsecamente irresponsáveis e desintegradores.

Cabe questionar se realmente o Banco Central, braço direito do Poder Executivo, deve ficar livre das pressões provenientes das crises e instabilidades. Afinal, deve-se pensar sobre o tipo de pressão que se quer evitar, pois elas podem ser benignas ou malignas ${ }^{172}$. Podem ser, inclusive, pressões exercidas pela própria sociedade como forma de reivindicar mudanças e controlar/fiscalizar a atuação dos bancos centrais.

Conforme destaca Maria Cristina Penido de Freitas ${ }^{173}$, o Banco Central não é uma instituição apolítica, com a função "natural” de garantir a estabilidade de preços:

\footnotetext{
${ }^{171}$ CARVALHO, Fernando J. Cardim. op. cit., p. 140.

${ }^{172} \mathrm{Na}$ Itália, o presidente do banco central era nomeado por um conselho bancário autônomo, tinha mandato por tempo indeterminado, inclusive sem limitação de idade. Essa estrutura era tida como a responsável pela estabilidade econômica daquele país, pois possibilitava que o Banco Central atuasse de forma independente e livre das pressões políticas do "instável" governo italiano. No entanto, verificou-se em 2005, com a superveniência de notícias sobre corrupção, abuso de poder e fornecimento de informações privilegiadas, envolvendo a falência da Parmalat, e também a venda do banco italiano Antonveneta ${ }^{172}$, o então presidente - Antonio Fazio - foi pressionado politicamente a pedir demissão. O sistema de banco central independente na Itália foi considerado falho a partir destes escândalos. A concentração de poder nas mãos de seu presidente e o controle quase nulo sobre seus atos - dado que o conselho bancário autônomo geralmente era "cooptado" pelas influências de seu dirigente - tornou a manutenção de tal estrutura insustentável. A reforma na legislação levou à adoção de uma nova sistemática na qual o presidente do banco central ${ }^{172}$ tem $^{-1}$ mandato fixo de seis anos renováveis apenas uma vez e com poderes reduzidos, no qual todas as suas medidas, como condição para entrada em vigor, devem ser aprovadas pelo Conselho de Diretores do banco. Fontes: "Can You Bank on Italy?", publicado em 09/10/2005 no site da revista Times. Disponível em: <http://www.time.com/time/magazine/article/0,9171,1115663,00.html>. Acesso em: 18 out. 2009. "Danneggiata reputazione del Paese", publicado no site da revista Reppublica em 04/08/2005. REPPUBLICA.IT Disponível em: <http://www.repubblica.it/2005/h/sezioni/economia/banche10/banche10/banche10.html?ref=search>. Acesso em: 18 out. 2009.

${ }^{173}$ FREITAS, Maria Cristina Penido de. Banco Central independente e coordenação das políticas macroeconômicas: lições para o Brasil. Economia e Sociedade, Campinas, v. 15, n. 2, p. 281, ago. 2006.
} 
Os estudos econométricos, ao exigirem uma abordagem mais objetiva da noção de independência, acabam por desconsiderar os diversos elementos qualitativos desse conceito, essencialmente ambíguo. Isso porque, na prática, o comportamento dos bancos centrais e seu relacionamento com o poder executivo vão muito além dos aspectos formais incorporados nos modelos. Na crítica pós-Keynesiana também é ressaltada a importância da história para a compreensão do desenvolvimento da institucionalidade monetária e financeira da economia capitalista. $\mathrm{O}$ banco central não é uma instituição apolítica, com a função "natural" de garantir a estabilidade de preços e por consequência a estabilidade do valor da moeda como sugerem alguns dos defensores da teoria da independência do banco central.

Ao contrário, o Banco Central é parte do Estado e a este deve estar subordinado de modo que as suas ações possibilitem o alcance de objetivos maiores e mais essenciais do que o cumprimento de "metas inflacionárias" à custa de uma taxa de juros extorsiva, à custa da opressão da oferta de crédito, à custa da inanição da atividade empresarial, à custa do desenvolvimento da nação, à custa da supressão de direitos fundamentais do indivíduo.

Portanto, verifica-se que o Banco Central, por representar um poderoso instrumento alocativo de recursos e de estabilização, é uma peça essencial ao modelo de estado comprometido com o desenvolvimento, sendo inconcebível o exercício de uma adequada política econômica sem a utilização adequada dessa ferramenta e com vistas a seguir os princípios constitucionalmente previstos para a política econômica.

\subsection{Os Bancos Centrais e a Política Monetária - Análise de Casos}

Serão objeto de estudo, a seguir, os dois maiores e mais representativos Bancos Centrais do mundo - Federal Reserve System e o Banco Central Europeu. Embora ambos representem uma sistemática bastante diferente da brasileira, por sua relevância no cenário mundial, não poderiam deixar de ser mencionados.

Adicionalmente, serão objeto de análise, os Bancos Centrais e a sua forma de atuação. Foram selecionados para esta verificação, por possuírem uma realidade supostamente mais similar à da brasileira no que tange às características de subdesenvolvimento, processos democráticos conturbados e um histórico de superinflações econômicas, os Bancos Centrais de três países latino-americanos (Chile, Venezuela e 
Argentina). Tais peculiaridades sociopolíticas poderão corroborar as conclusões empreendidas neste trabalho, especialmente para o caso brasileiro.

O próximo capítulo será integralmente voltado à análise do Banco Central do Brasil.

\subsubsection{Federal Reserve System (FED)}

O Federal Reserve System (FED) possui estrutura diferenciada dos demais Bancos Centrais dado que, na verdade, não é um banco central, mas um complexo de instituições financeiras, que, de acordo com as atividades a elas atribuídas, atuam exercendo as funções típicas de banco central.

Estruturado de maneira pulverizada, o FED conta com unidades divididas por regiões geográficas dos Estados Unidos. Essa formação peculiar, apesar de complexa, possibilita maior proximidade com a realidade de cada região geográfica do país e possibilita maior conhecimento das necessidades, problemas e anseios específicos de cada uma delas.

Atualmente o FED é composto pelo Board of Governors, em Washington, D.C., constituído por sete membros indicados pelo presidente e confirmados pelo senado, e por mais doze Reserve Banks regionais que funcionam como extensões do FED em cada região.

Em conjunto, o Board of Governors e os doze Reserve Banks dividem a responsabilidade de supervisionar e regular as atividades desempenhadas pelas instituições financeiras dos Estados e de assegurar que os consumidores recebam informações e tratamento adequados sobre o sistema bancário.

O principal órgão componente do FED é o Federal Open Market Committee (FOMC), composto por membros do Board of Governors, pelo presidente do Reserve Bank de Nova Iorque e por quatro presidentes de outros Reserve Banks que se revezam entre os onze. O FOMC supervisiona as operações no open market ${ }^{174}$ - a principal ferramenta do FED para influenciar as condições monetárias e creditícias do país.

\footnotetext{
${ }^{174}$ Mercado no qual os bancos centrais operam com títulos públicos para regular e controlar os meios de pagamento, ao mesmo tempo que financiam a dívida federal interna.
} 
O FED possui em sua estrutura comitês consultivos ${ }^{175}$; os principais são: (i) o Federal Advisory Counsil, composto por doze representantes do sistema bancário que se reúnem quatro vezes ao ano e assessoram o FED em todos os temas que versam sobre o sistema financeiro dos Estados Unidos; (ii) o Consumer Advisory Council, estabelecido em 1976, aconselha o Board a respeito das matérias que envolvem o consumidor e os serviços financeiros a eles prestados. Os membros do comitê representam os interesses dos consumidores da comunidade e também do sistema bancário. Reúne-se três vezes ao ano e as reuniões são abertas ao público em geral e (iii) o Thrift Institutions Advisory Council, comitê que se reúne três vezes ao ano para obter informações e opiniões das instituições de crédito.

Fundado em 1913, o FED possui os seguintes parâmetros ${ }^{176}$ de atuação: (i) conduzir a política monetária influenciando as condições monetária e de crédito para buscar o pleno emprego, estabilidade de preços e taxas de juros de longo prazo em níveis moderados; (ii) supervisionar e regular as instituições bancárias para assegurar a higidez do sistema bancário e financeiro e proteger os direitos de crédito dos consumidores; (iii) manter a estabilidade do sistema financeiro e conter o risco sistêmico no mercado financeiro; (iv) oferecer serviços financeiros para instituições depositárias, para o governo norte-americano e instituições estrangeiras oficiais, inclusive desempenhando papel ativo no sistema de pagamentos da nação.

Quanto a sua autonomia, entende-se que o processo de independência ocorreu de forma natural. Em 1913 já havia menção em seus estatutos quanto à independência, todavia muitos defendem que tal independência era muito mais relacionada com a Wall Street do que com o governo norte-americano - a bem da verdade, a questão sobre o FED poder ou não ser considerado independente é polêmica; depende dos critérios adotados

\footnotetext{
${ }^{175}$ No Brasil houve a tentativa de replicar esta estrutura, criando-se comissões consultivas compostas por representantes de setores significativos da sociedade, os quais deveriam auxiliar o Conselho Monetário Nacional na formulação das políticas públicas, nos termos do disposto na Lei 6404/1964. Todavia, não lograram o mesmo sucesso conforme será possível verificar no capítulo seguinte.

176، Today, the Federal Reserve's duties fall into four general areas: Conducting the nation's monetary policy by influencing the monetary and credit conditions in the economy in pursuit of maximum employment, stable prices, and moderate long-term interest rates; supervising and regulating banking institutions to ensure the safety and soundness of the nation's banking and financial system and to protect the credit rights of consumers; maintaining the stability of the financial system and containing systemic risk that may arise in financial markets; providing financial services to depository institutions, the U.S. government, and foreign official institutions, including playing a major role in operating the nation's payments system". BOARD of Governors of the Federal Reserve System Washington, D.C. The Federal Reserve System Purposes and Functions, 9. Disponível em: <http://www.federalreserve.gov/pf/pdf/pf_complete.pdf>. Acesso em: 04 abr. 2009.
} 
para essa avaliação, especialmente devido a sua estrutura diferenciada e ao comportamento, ora mais, ora menos independente adotado por seu corpo diretivo.

De todo modo, pode-se dizer que o FED vem desempenhando suas atividades de forma autônoma ${ }^{177}$, mas coordenada com as diretrizes traçadas pelo governo ${ }^{178}$ devido ao fato de que suas decisões não são ratificadas pelo presidente nem por outro órgão do governo norte-americano, todavia suas atividades estão sob permanente controle do Congresso. Tem o dever de atuar em parceria com os objetivos de política econômica estabelecidos pelo governo. Por isso é tido como independent within the government.

Neste ponto, cabe destacar que o FED, pela estrutura que o conforma, denota um positivo grau de proximidade com a sociedade. Além de estar dividido em unidades regionais que se reportam a um centro de poder, conforme visto, é assessorado por comitês consultivos especializados em determinados assuntos considerados relevantes. Esses comitês são compostos por membros da sociedade que pertencem às classes de pessoas afetadas diretamente por sua atuação. Não há dúvida de que, nessa estrutura, o controle e a prestação de contas tendem a ser mais eficazes.

Em interessante artigo sobre o tema, João $\operatorname{Sicsú}^{179}$ analisou o caso específico do FED adotando alguns métodos científicos empregados por Alex Cukierman para medir a independência dos bancos centrais. Fundado em tais métodos, analisou uma série de episódios marcantes ao longo da história do FED em que se poderia eventualmente identificar conflito com o Poder Executivo, tais como: Primeira Guerra Mundial, Grande Depressão, Segunda Guerra e assim por diante.

Com base na análise deste caso, Sicsú chegou à conclusão de que não basta que formalmente haja uma norma determinando a independência dos bancos centrais. Suas ações são diretamente influenciadas pela personalidade dos indivíduos que comandam os

\footnotetext{
${ }^{177}$ Ou pelo menos atuava até a eclosão da crise econômica em 2008 que teve como causa, entre outros fatores, a falta de controle das atividades desempenhadas pelos bancos. Assim, pode-se questionar até que ponto a tão festejada autonomia do FED contribuiu para o descontrole das atividades do mercado financeiro nos Estados Unidos e na crise mundial que se seguiu.

${ }^{178}$ O Federal Reserve System americano apresenta três características até certo ponto únicas, que contribuem de forma decisiva para sua estruturação e que influem decisivamente para a configuração de sua autonomia, quais sejam: o caráter público-privado de sua organização; os mecanismos de controle do poder e da autonomia do sistema e a limitação dos objetivos do Federal Reserve System. SADDI, Jairo Sampaio. Autonomia do Banco Central. 1996. Tese (Doutorado) - Faculdade de Direito, Universidade de São Paulo, USP, São Paulo, 1996. p. 114.

${ }^{179}$ SICSÚ, João. Tese da independência do Banco Central e a estabilidade de preços: uma aplicação do Método Cukierman à História do FED. Estudos Econômicos, São Paulo, v. 6, n. 1, p. 21-49, jan./abr. 1996.
} 
postos-chave dessa relação, e pela conjuntura econômica, social e política enfrentada pelo país em questão:

Pode-se concluir ainda que mesmo quando o conjunto de regras formais estabelece um desenho institucional de um banco central como organismo independente (como é o caso americano), um fator altamente subjetivo e outro objetivo têm determinado a real autonomia das autoridades monetárias. $\mathrm{O}$ fator subjetivo refere-se à personalidade dos indivíduos que ocupam postos-chave seja no banco central seja no governo. $\mathrm{O}$ fator objetivo refere-se ao surgimento de conjunturas de total descontrole fiscal. (...) mesmo quando a independência das autoridades monetárias é estabelecida em lei, dois outros fatores têm determinado a verdadeira autonomia do BC: primeiro, a personalidade dos dirigentes do banco central e, segundo, a emergência de conjunturas de total descontrole fiscal - como são as situações de guerra. Portanto, a lição absorvida da história do FED é que a tese-teórica da IBC é incompleta para transformar-se em modelo de organização institucional-real porque as personalidades e comportamentos de indivíduos não podem ser predeterminados e conjunturas de total descontrole fiscal não podem ser evitadas exclusivamente com instrumentos econômicos e/ ou legais.

Do exposto, verifica-se que existem diversos graus de independência, que devem variar de acordo com as características institucionais de cada Banco Central inserido no contexto social de seu país. A mensuração do grau de independência, comumente, é uma tarefa bastante complexa, em virtude do caráter individualizado das experiências e do fato de que a legislação, conforme visto, em muitos casos se distancia da prática.

O ponto fundamental do qual não se deve prescindir diz respeito à possibilidade de coordenar a política monetária desenvolvida pelo Banco Central com os objetivos adotados pelas demais políticas estatais. O grau de independência que de alguma forma afete essa coordenação poderá prejudicar a consecução das políticas econômicas do Estado em questão, conforme asseverado no tópico anterior.

\subsubsection{Banco Central Europeu}

Certamente neste trabalho não poderia faltar a menção a uma estrutura bastante específica e recente, cujas características ainda estão sendo postas à prova, a qual, entretanto, vem modificando o conceito de autoridade monetária internacional.

Os países da Europa, desde a instituição do padrão-ouro, quando surgiram os primeiros bancos centrais, procuram articular-se para proporcionar uma certa uniformidade 
no que tange à condução da política externa. A busca por uma atuação coordenada e muitas vezes até protecionista dos Estados nacionais europeus parece mesmo uma história antiga.

As inúmeras guerras enfrentadas pelo continente possuem, sem dúvida, um conteúdo de disputa pelo poder, pela hegemonia e pela liderança, especialmente no que tange à Inglaterra, França e Alemanha. Com efeito, a União Européia possibilitou que juntas essas potências alcançassem aquilo que sozinhas não conseguiriam: enfrentar em pé de igualdade o poderio hegemônico norte-americano, conquistado no século XX pela consolidação do imperialismo germinado com a eclosão da Segunda Guerra Mundial e fertilizado com a adoção da paridade do dólar - ouro e, posteriormente, padrão-dólar como padrão monetário mundial.

A Europa, para não ser esmagada pelo poder incontestável alcançado pelos Estados Unidos a partir da segunda metade do século passado, para enfrentar as transformadoras novidades trazidas pela globalização financeira e para se proteger das crises econômicas em cadeia geradas por tal fenômeno contemporâneo, ao menos economicamente, integrouse para se fortalecer. Tornou-se uma só e, ao que parece, mais forte.

Essa inovadora estrutura é resultado de um longo e paulatino processo de integração e maturação de ideias e vem logrando sucesso desde os primeiros estágios de sua formação até os dias de hoje, em que a moeda única - o Euro - circula pelos países que a adotaram. Em decorrência dessa moeda única de curso legal, os bancos centrais nacionais pertencentes aos países integrantes da "zona do euro" dizem 'Amém!' para a política monetária emanada do organismo supranacional mais bem-sucedido de nossa era, a União Europeia $^{180}$, instituído pela assinatura do Tratado da União Europeia, em Maastricht, em 1992.

Após a assinatura do Tratado, pode-se identificar três fases distintas de evolução pela qual passou a União Europeia. A primeira delas, entre 1990 e 1993, caracterizou-se pela constituição de um mercado único europeu, possibilitando a livre circulação de pessoas, mercadorias, capital e serviços na Europa.

\footnotetext{
${ }^{180} \mathrm{Em}$ 1952, foi fundado o embrião da Comunidade Europeia. Tratava-se da Comunidade Europeia do Carvão e do Aço (CECA), constituída por seis países - Alemanha, Bélgica, França, Itália, Luxemburgo e Países Baixos. Seis anos depois, os mesmos seis países criaram a Comunidade Econômica Europeia (CEE) e a Comunidade Europeia da Energia Atômica (EURATOM). Essa rede de relações diplomáticas construiuse aos poucos e foi essencial para alicerçar a rede de confiança e parceria desses países, o que culminou com a assinatura do Tratado de Maastricht em 1993, instituindo-se, então, a União Europeia. Banco Central Europeu - Eurosistema. Versão portuguesa da brochura disponível no site do BCE. (Disponível em: $<$ www.ecb.europa.eu>).
} 
A segunda fase teve início com a criação do Instituto Monetário Europeu e durou de 1994 a 1998. Trata-se do período mais decisivo na formação do bloco, tendo em vista que possibilitou a real integração e equiparação econômica entre os países e foi dedicada aos preparativos técnicos para a moeda única e ao reforço da uniformização das políticas monetárias dos Estados-Membros.

A terceira e última fase iniciou-se em 1999 com a fixação das taxas de câmbio, a transferência da responsabilidade pela política monetária dos Bancos Centrais nacionais para o Banco Central Europeu e, finalmente, o Euro passou a ter curso legal em $1 .^{\circ}$ de janeiro de 2002 .

Com a evolução do sistema, o número de países integrantes ${ }^{181}$ também cresceu gradualmente, à medida que as etapas evolutivas do projeto foram tomando corpo e ganhando credibilidade. Essa adesão em massa das nações Europeias, especialmente Europa Oriental, teve de ocorrer de forma equilibrada a fim de não gerar desestabilizações para o bloco. Nesse sentido, foram estatuídos os critérios de Copenhagen ${ }^{182}$ os quais propunham um sistema de convergência hábil a determinar se os países estariam ou não estariam prontos para ingressar na União Europeia, passando à próxima fase.

Assim, para ingressarem na União Europeia, os países deveriam atender às seguintes condições:

(i) instituições estáveis, que garantam a democracia, o Estado de Direito, os direitos humanos, o respeito pelas minorias e a sua protecção, e (ii) a existência de uma economia de mercado viável e capacidade para fazer face à pressão da concorrência, de modo a poderem assumir as obrigações decorrentes da sua qualidade de membros, incluindo os objectivos de uma união política, económica e monetária ${ }^{183}$.

\footnotetext{
${ }^{181}$ A Dinamarca, a Irlanda e o Reino Unido aderiram em 1973, seguidos da Grécia oito anos mais tarde. Portugal e Espanha tornaram-se membros em 1986 e a Áustria, a Finlândia e a Suécia em 1995. O alargamento do bloco prosseguiu em 2004, com a adesão do Chipre, Eslováquia, Eslovênia, Estônia, Hungria, Letônia, Lituânia, Malta, Polônia e República Checa. Por fim, a Bulgária e a Romênia passaram a ser Estados-Membros da União Europeia em janeiro de 2007. Cabe destacar que a Suécia e nove dos doze países que aderiram em 2004 são considerados "membros por derrogação", pois ainda não cumpriram todas as condições de convergência necessárias para integrarem plenamente a União Europeia. Além disso, Dinamarca e Reino Unido não adotaram o Euro como moeda única e, por isso, não participaram da terceira fase estabelecida pelo Tratado de Maastricht. Banco Central Europeu - Eurosistema. Versão portuguesa da brochura disponível no site do BCE (Disponível em: <www.ecb.europa.eu>).

${ }^{182}$ Banco Central Europeu - Eurosistema. Versão portuguesa da brochura disponível no site do BCE (Disponível em: <www.ecb.europa.eu>).

${ }^{183}$ Id. Ibid.
} 
Esse sistema de convergência entre os países visou à avaliação de quais deles estavam aptos a adotar uma moeda única sem comprometer a higidez do sistema. Tais critérios estão definidos no Tratado de Maastricht e podem ser resumidos no seguinte: (i) elevado grau de estabilidade de preços; (ii) finanças públicas sólidas; (iii) uma taxa de câmbio estável e (iv) taxas de juros de longo prazo baixas e estáveis.

Estes critérios foram concebidos para assegurar que apenas os países com políticas econômicas orientadas e consistentes com o histórico de estabilidade de preços pudessem passar à terceira fase do projeto.

Quanto a organização, pode-se dizer que o Sistema Europeu de Bancos Centrais (SEBC) é constituído pelo Banco Central Europeu (BCE) e pelos bancos centrais nacionais dos Estados Membros da União Europeia (UE). Compõem a sua estrutura um Conselho do BCE e uma Comissão Executiva. As funções do SEBC são designadas pelas disposições do de Maastricht e dos Estatutos do Sistema Europeu de Bancos Centrais e do Banco Central Europeu. O SEBC é dirigido pelos órgãos de decisão do BCE. O Conselho do BCE define a política monetária, enquanto a Comissão Executiva encarrega-se de executá-la.

O BCE recorre aos bancos centrais nacionais para que estes efetuem as operações que fazem parte das atribuições do Eurosistema. As operações de política monetária do Eurosistema são executadas em termos e condições uniformes em todos os EstadosMembros.

O objetivo primordial do Eurosistema é manter a estabilidade de preços, tal como definido no artigo $105 .^{\circ}$ do Tratado $^{184}$. Deve, também, apoiar as políticas econômicas gerais na Comunidade Europeia.

O objectivo primordial do Eurosistema é a manutenção da estabilidade de preços . Sem prejuízo desse objectivo, o Eurosistema apoia as políticas económicas gerais da Comunidade. (...) O Eurosistema contribui para esses objectivos mantendo a estabilidade de preços. Além disso, na prossecução da estabilidade de preços, tem esses objectivos em consideração. Caso exista qualquer conflito entre os objectivos, o BCE tem sempre de dar prioridade à manutenção da estabilidade de preços $^{185}$.

\footnotetext{
${ }^{184}$ Tratado de Maastricht - Capítulo II - A política monetária

Artigo 105.1. O objectivo primordial do SEBC é a manutenção da estabilidade dos preços. Sem prejuízo do objectivo da estabilidade dos preços, o SEBC apoiará as políticas económicas gerais na Comunidade tendo em vista contribuir para a realização dos objectivos da Comunidade tal como se encontram definidos no artigo 2o O SEBC actuará de acordo com o princípio de uma economia de mercado aberto e de livre concorrência, incentivando a repartição eficaz dos recursos e observando os princípios definidos no artigo 3o-A.

185“Banco Central Europeu - Eurosistema" Versão portuguesa da brochura disponível no site do BCE, (Disponível em: <www.ecb.europa.eu>).
} 
O Tratado impõe também que o banco central do respectivo país seja independente. ${ }^{186}$ Nesse sentido, ao exercerem as funções relacionadas com o Eurosistema, o BCE e os BCN não devem solicitar ou receber instruções de instituições ou organismos comunitários, dos governos dos Estados-Membros ou de qualquer outra entidade.

Igualmente, é vedado às instituições e organismos comunitários, bem como os governos dos Estados-Membros influenciar os membros dos órgãos de decisão do BCE ou dos BCN no exercício das suas funções.

A fim de assegurar tal independência, os Estatutos do SEBC prevêem a segurança dos mandatos dos governadores dos BCN e dos membros da Comissão Executiva do BCE do seguinte modo:

i. um mandato mínimo de cinco anos, para os governadores dos $\mathrm{BCN}$;

ii. um mandato não renovável de oito anos para os membros da Comissão Executiva do BCE;

iii. a demissão dos membros da Comissão Executiva do BCE apenas em caso de incapacidade ou falta grave, sendo da competência do Tribunal de Justiça das Comunidades Europeias decidir sobre qualquer litígio ${ }^{187}$.

No momento de definição e execução das políticas monetárias, o Eurosistema é também independente. O BCE e os BCNs estão autorizados a decidir autonomamente como e quando utilizar os mecanismos hábeis a conduzir a política monetária de acordo com os objetivos estabelecidos para a economia pelo SEBC. Por fim, não é permitido ao Eurosistema conceder empréstimos a organismos comunitários ou a entidades do setor público nacional, pois isso poderia interferir e comprometer seu acordo com a independência.

\footnotetext{
${ }^{186}$ Tratado de Maastricht - Capítulo II - A política monetária Artigo 107 - No exercício dos poderes e no cumprimento das atribuições e deveres que lhes são conferidos pelo presente Tratado e pelos Estatutos do SEBC, o BCE, os bancos centrais nacionais, ou qualquer membro dos respectivos órgãos de decisão não podem solicitar ou receber instruções das Instituições ou organismos comunitários, dos governos dos Estados-membros ou de qualquer outra entidade. As Instituições e organismos comunitários, bem como os governos dos Estados-membros, comprometem-se a respeitar este princípio e a não procurar influenciar os membros dos órgãos de decisão do BCE ou dos bancos centrais nacionais no exercício das suas funções.

187 "Banco Central Europeu - Eurosistema”. Versão portuguesa da brochura disponível no site do BCE, (Disponível em: <www.ecb.europa.eu>).
} 
De todo o exposto, no que tange ao Banco Central Europeu, verifica-se que a estrutura supranacional gerada para política e financeiramente fortalecer os paísesmembros da União Europeia é bastante diferenciada e passa por uma fase de testes. Não é possível, ainda, afirmar que seus objetivos serão completamente atingidos, tampouco que todos os países permanecerão aderentes a tal estrutura mesmo quando frontalmente os comandos supranacionais desagradarem seus interesses e necessidades específicos.

Para os fins dos estudos desenvolvidos neste trabalho, deve-se concluir que a independência dos Bancos Centrais de cada nação é premissa para o funcionamento do sistema. Não seria lógico que os bancos centrais nacionais atuassem de forma coordenada com os respectivos Estados em detrimento das determinações do Banco Central Europeu, pois isso desencadearia o seu colapso.

A verdade é que, em larga medida, os países-membros da União Europeia abriram mão de sua soberania em troca da promessa de incremento das atividades comerciais, do desenvolvimento e, também, da proteção de uma entidade política mais forte e respeitada no cenário internacional. Somente unidos, os países da Europa poderiam concorrer em pé de igualdade com a potência norte-americana.

Portanto, a partir do momento em que decidiram unir-se, esses países assumiram o ônus de agir de acordo com as determinações superiores e de forma coordenada, tendo deixado de possuir todas as características definidoras do Estado Moderno como o conhecemos, uma vez que não têm mais liberdade para escolher/planejar os próximos passos do país conforme suas necessidades e peculiaridades, a não ser de forma coordenada com todos os outros membros.

Por isso não faria sentido, nem seria apropriado querer comparar a independência dos bancos centrais da Europa - premissa essencial para a existência do bloco - com a independência dos bancos centrais pertencentes a Estados tipicamente soberanos e que carregam a missão de, sozinhos, decidir os caminhos a trilhar, pois, nesse caso, o Banco Central efetivamente deve estar ajustado a tais objetivos para viabilizar o seu alcance.

Portanto, aqueles que tentarem defender ou refutar a tese da independência dos bancos centrais com base na posição adotada pelos países integrantes da União Europeia estarão apoiando-se num argumento falho, dado que, neste caso, como se viu, o contexto é totalmente distinto. 


\subsubsection{Bancos Centrais da América Latina}

De início, cumpre ressaltar que as instabilidades políticas tão recorrentes nos países da América Latina impossibilitam, em larga medida, a concretização da independência dos bancos centrais ainda que ela esteja formalmente estatuída na maioria deles.

A inviabilidade concreta da aplicação do modelo confirma os argumentos expostos de que a aclamada independência dos bancos centrais em parceria com o estabelecimento de metas inflacionárias como prioridade de política monetária (pacote vendido como a salvação no contexto das diretrizes do Consenso de Washington) não se adaptam às necessidades e peculiaridades dos países ao sul do Equador. Essa é a realidade verificada nos três países que se analisam a seguir.

Nas palavras de Eugênio Gudin ${ }^{188}$, a estrutura do Banco Central de cada país deve adaptar-se, de acordo com o tipo de economia, ao grau de desenvolvimento de seu sistema bancário, conforme a sua extensão territorial e especialmente com o grau de educação política de sua população.

Especificamente a respeito da condição dos Bancos Centrais na América Latina, Eugênio Gudin pondera:

Seja dito de início que banco central não é panacéia capaz de pôr termo às vicissitudes monetárias de países cujos padrões de incapacidade os mantêm em estado de desregramento monetário crônico. Um banco central criado nesse clima, com diretores nomeados por critérios políticos, incapazes de resistir à pressão inflacionária do governo, só serve para desmoralizar a instituição. Não tem banco central quem quer, e sim quem já atingiu um padrão mínimo de ordem financeira e administrativa capaz de permitir seu funcionamento eficaz.

Num regime democrático, dotado de alta representatividade da sociedade por meio dos órgãos políticos e constante fiscalização das atividades desenvolvidas pelo próprio Estado, será mais fácil garantir ao Banco Central a possibilidade, segundo o autor, de que se execute uma política monetária mais eficiente.

Feitas as considerações iniciais, cabe passar-se à análise dos casos.

${ }^{188}$ GUDIN, Eugênio. op. cit., v. 1, p. 273. 


\subsubsection{Banco Central do Chile}

O Chile tem uma política externa ajustada à dos Estados Unidos desde o golpe que depôs o então presidente democraticamente eleito, Salvador Allende, em 1973. Foi considerado um exemplo "bem-sucedido" na implantação das diretrizes do Consenso de Washington. É, também, a sede da CEPAL ${ }^{189}$, principal centro intelectual sobre vias alternativas para o desenvolvimento do terceiro mundo. Além disso, esse país cultiva uma longa tradição de interdependência com seus países vizinhos, especialmente no que tange aos episódios sociopolíticos que se repetiram quase simultaneamente em todos eles, tais como os movimentos de independência, a ditadura militar e a redemocratização do Estado $^{190}$.

O Banco Central do Chile ${ }^{191}$ foi fundado pela edição do Decreto-Lei 486, de 21.08.1925 (a sua Primeira Lei Orgânica), com o objetivo de regular a emissão de moeda e o sistema financeiro. Na década de 1940, adquiriu novas funções, tais como: proporcionar desenvolvimento econômico, controlar a política fiscal e financeira e promover reformas sociais.

Em 1953, a maioria dessas funções adicionais foi incorporada formalmente ao seu estatuto, sendo editada a Segunda Lei Orgânica do Banco Central chileno (D.F.L. n. 106 de 06.06.1953) que, além disso, determinou formalmente a sua autonomia. Embora essa norma tenha trazido muitas inovações, tais como a nomeação de quatro conselheiros parlamentares, para auxiliarem na formulação da política monetária, e a ampliação do escopo de atuação do Banco Central, o fato é que a inflação nesse período chegou a patamares expressivos o que trouxe como consequência a instabilidade política no país. Aventou-se que o problema seria o excesso de funções desempenhadas pelo Banco Central que não poderia concentrar-se na formulação e execução de uma política monetária adequada.

\footnotetext{
${ }^{189}$ Comissão Econômica para a América Latina e o Caribe (CEPAL) foi criada em 1948, dentro de um movimento geral da Organização das Nações Unidas para implantar, em cada continente, núcleos de apoio ao planejamento das economias após a Segunda Guerra.

${ }^{190}$ SANTORO, Maurício. O modelo chileno e os dilemas da América do Sul. Observatório Político SulAmericano-Instituto Universitário de Pesquisas do Rio de Janeiro IUPERJ/UCAM. Disponível em: $<w w w . o b s e r v a t o r i o . i u p e r j . b r>$.

${ }^{191}$ As informações sobre o Banco Central do Chile foram obtidas no "Center for The Study of Central Banks" da New York University School of Law (NYU), por meio do site: NYU. Index of Documents from the Center for the Study of Central Banks Collection. Disponível em: <http://www1.law.nyu.edu/centralbankscenter/texts/order.html>. Acesso em: 18 out. 2009.
} 
Em 1960, a Terceira Lei Orgânica do Banco Central (DFL 247 de 30.03.1970) criou o Comitê Executivo a fim de implantar os objetivos determinados pela sua diretoria. Com isso, o poder de decisão sobre a política monetária estaria concentrado nas mãos de um Comitê capacitado tecnicamente para fazê-lo. Por fim, em 1975, houve uma nova reforma na Lei Orgânica do Banco Central do Chile (Decreto-Lei 1078, de 25.06.1975 ${ }^{192}$ ), que reduziu o âmbito de atuação da política monetária para um único objetivo - o cumprimento das metas de inflação ${ }^{193}$.

Como visto, a partir do momento em que se institucionaliza uma meta específica simples e objetiva, a independência do Banco Central aplica-se com maior facilidade. Em 1975 o Banco Central do Chile tornou-se independente tal como formalmente estabelecido anos antes. Cabe, no entanto, questionar se, em nome da real independência, a estabilidade deve ser o único objetivo da política econômica e determinar qual o custo social de tal medida.

Atualmente, no Banco Central do Chile há cinco Conselheiros eleitos pelo Senado Federal e nomeados pelo Presidente da República para um mandato fixo de dez anos. O objetivo dessa estrutura consiste em proteger a cúpula do banco das "pressões políticas" e da troca de governos.

A autonomia do Banco Central do Chile é compensada pela transparência na divulgação das ações implantadas pelo Banco Central, a qual inclui a publicação dos informes de Política Monetária com o objetivo de esclarecer ao público em geral a

\footnotetext{
${ }^{192}$ This legal body is called the Organic Law of the Monetary Council and of Banco Central de Chile (L.O.B.C.) and was first published in the Official Gazette on July 28, 1975 as Law Decree Nr. 1,078. The text referred to herein includes all the amendments introduced up until January 27, 1982. The specific faculties of Banco Central according to the present legislation may be divided into two categories: one that is clearly regulating and another that refers to the intervention of financial markets. The main faculties of the regulatory type are: carrying out and controlling international exchange operations, establishing limits in the asset-liability relation for all financial entities, terms of issue for financial instruments, and determining cash positions and technical reserves affecting financial institutions. This category also includes all general regulations related to the juridical-institutional context governing these entities. A second category contains the faculties of Banco Central that could eventually allow for a financial market intervention.(...) Notwithstanding the above, the authority's monetary policy has been one of nonintervention and non-discrimination in terms of instruments and among entities of the same type. The basic principle has been to establish a clear and permanent type of regulation for financial agents. ( NYU. Index of Documents from the Center for the Study of Central Banks Collection. Disponível em: $<$ http://www1.law.nyu.edu/centralbankscenter/texts/order.html>. Acesso em: 18 out. 2009).

193،Es labor fundamental del BC velar por la estabilidade de la moneda y el normal funcionamiento de los pagos internos y externos, siendo sus atribuciones la regulación de la cantidad de dinero y de crédito en circulación, la ejecución de operaciones de crédito y cambios internacionales y la dictación de normas en materia monetaria, credítica, financiera y de cambios internacionales." NOVOA GALAN, Raul; NOVOA MUNHOZ, Gabriela. Derecho del mercado de capitales. Santiago: Editorial Jurídica de Chile, 1995. p. 152.
} 
evolução da economia, com possíveis desdobramentos no desemprego e nas decisões políticas.

La autonomía del BC puede ser analizada desde dos puntos de vista, pero con el mismo objeto señalado precedentemente. Es así como el BC tiene autonomía de dirección (con el objeto de que las decisiones adoptadas por la entidad sean exclusivamente de carácter técnico sin sujeción a instrucciones de otros poderes del Estado como el Executivo) y que se manifiesta en distintas normas de la Ley $\mathrm{n}^{\circ} 18840$, como es, por ejemplo, la designación de los miembros del Consejo del BC, como autonomía de patrimonio (el $\mathrm{BC}$ tiene capital y reservas propios que administra libremente sin sujeción a instrucciones del Poder Ejecutivo) ${ }^{194}$.

Segundo Vittorio Corbo ${ }^{195}$, “a diretoria do Banco Central chileno está consciente do seu papel na política monetária e age para alcançar a estabilidade de preços”. A orientação do Banco Central chileno ao mercado dá-se por meio do sistema de metas de inflação em longo prazo. A cada três meses, o presidente do Banco Central presta contas da sua atuação ao povo e ao Senado, apontando os rumos da economia.

Embora conceitualmente esse possa ser considerado um caso de sucesso no que tange à autonomia do Banco Central, cabe destacar que existe um efetivo controle, especialmente pelos Poderes Legislativo e Executivo, quanto às suas atividades, bem como prestação de contas à sociedade quanto a sua atuação ${ }^{196}$.

Além disso, a autonomia do Banco Central do Chile não existe de forma absoluta, nos termos defendidos por alguns dos doutrinadores mais radicais. Embora no artigo primeiro ${ }^{197}$ de sua Lei Orgânica esteja expresso que se trata de um organismo autônomo, logo em seguida, em seu artigo quarto, verifica-se a atuação coordenada com os Poderes Executivo e Legislativo.

\footnotetext{
${ }^{194}$ NOVOA GALAN, Raul; NOVOA MUNHOZ, Gabriela. op. cit., p. 151.

${ }^{195}$ Entrevista concedida por Vittorio Corbo, então diretor do Banco Central do Chile, em visita ao Brasil, à Agência Senado, em 07.06.2005. SENADO FEDERAL. Disponível em: <www.senado.gov.br/agencia>. Acesso em: 18 out. 2009.

${ }^{196}$ Ao acessar a página principal do Banco Central do Chile, é possível obter todos os tipos de informações necessárias à compreensão de sua política monetária, relatórios atualizados, dados econômicos e históricos sobre o banco e, inclusive, a remuneração dos dirigentes do conselho. (BANCO CENTRAL. CHILE. Disponível em: <www.bcentral.cl>. Acesso em: 18 out. 2009).

${ }^{197}$ Ley Orgánica Constitucional del Banco Central de Chile - Artículo 1. ${ }^{\circ}$. El Banco Central de Chile es un organismo autónomo, de rango constitucional, de carácter técnico, con personalidad jurídica, patrimonio propio y duración indefinida. Esta ley establece su organización, composición, funciones y atribuciones. Cada vez que en esta ley se use la expresión "Banco", se entenderá que se alude al organismo señalado en este artículo. (BANCO CENTRAL. CHILE. Disponível em: <www.bcentral.cl>. Acesso em: 18 out. 2009).
} 
Artículo 4. ${ }^{\circ}$ El Banco deberá informar al Presidente de la República y al Senado a respecto de las políticas y normas generales que dicte en el ejercicio de sus atribuciones. Asimismo, deberá asesorar al Presidente de la República, cuando éste lo solicite, en todas aquellas materias que digan relación con sus funciones.

Além disso, no que tange à relação do Banco Central com o Tesouro, embora a Constituição do Chile vede expressamente qualquer tipo de financiamento público, observa-se a exceção dos casos em que esteja ameaçada a segurança nacional.

De conformidad a la Constituición Política de la República de Chile del año 1980, el BC podrá otorgar financiamento sólo a empresas bancarias y sociedades financieras, sin embrago, no podrá otorgar a ellas su garantía, ni adquirir documentos emitidos por el Estado, sus organismos o empresas. Lo anterior con la excepción de que en caso de guerra exterior o peligro de ella (situación que debe calificar el Consejo de Seguridad Nacional) el BC podrá obtener, otorgar o financiar créditos al Estado y entidades públicas o privadas. De esta manera, ningún gasto público o préstamo puede financiarse con créditos directos o indirectos del Banco Central ${ }^{198}$.

Trata-se, portanto, de um caso excepcional em que a democracia e a representatividade do Senado na atuação do Banco Central possibilitaram a condução da política econômica de forma autônoma, porém coordenada.

\subsubsection{Banco Central da Venezuela}

O Banco Central da Venezuela foi fundado em 1939, durante a presidência de Eleazar López Contreras, num contexto de profundas mudanças sociais no país e no mundo. Não só era o início da Segunda Guerra Mundial como também o fim de uma ditadura que durou os 27 anos de governo do General Juan Vicente Gómez.

O novo governo elaborou um plano nacional denominado "Programa de Febrero" que contemplou uma série de medidas de política econômica, entre as quais a mais importante foi a fundação do Banco Central ${ }^{199}$.

\footnotetext{
${ }^{198}$ NOVOA GALAN, Raul; NOVOA MUNHOZ, Gabriela. op. cit., p. 152.

${ }^{199}$ A criação do banco central enfrentou, na Venezuela, como no Brasil e na maioria dos países da América Latina que, de início não compreendiam muito bem a sua utilidade, uma forte resistência dos setores nacionais mais conservadores que consideravam uma ameaça à estabilidade monetária tendo em vista a possibilidade da ocorrência de um fácil e incontrolável financiamento do gasto público por parte do Banco Central. Além disso, havia a resistência a um único banco que estabelecesse a centralização e a
} 
Em 1992, formalmente ganhou status de independente ${ }^{200}$ e se estabeleceu um órgão colegiado de sete membros, um Presidente e seis diretores designados pelo presidente da República, com um mandato de seis anos. A indicação do Presidente da República deveria submeter-se à aprovação do Senado, enquanto a representação do Executivo no Colegiado se reduziria a um Diretor, o qual, em nenhuma hipótese, poderia ser o Ministro da Fazenda. Outra novidade foi a proibição expressa de que o Banco Central outorgasse crédito direto ao Governo e, ainda, a obrigação imposta ao Estado de restituir o patrimônio do Banco Central se este incorresse em perdas decorrentes da aplicação de suas políticas.

Embora formalmente muito bem alinhavada estivesse essa independência sob o ponto de vista normativo, entre as décadas de 1980 e 1990, as sucessivas quedas do preço do petróleo levaram culminaram com uma grave crise econômica a qual levou o então presidente, Carlos Andrés Perez (1989 a 1983), de maneira coordenada com o Banco Central, a recorrer a organismos internacionais, entre eles o Fundo Monetário Internacional para a obtenção de auxílio financeiro.

Os indicadores sociais confirmam as profundas marcas sociais da crise: entre 1980 e 1990 o desemprego aberto sobe de 6\% para $11 \%$ e a informalização de 35,4\% para 41,8\%; o salário médio real em 1990 equivalia a $49,8 \%$ do de 1978 . Com isso, os níveis de pobreza e indigência da população entre 1981 e 1990 atingiram cifras inusitadas: a porcentagem dos domicílios cujas famílias se encontravam abaixo da linha de pobreza sobe de 22 para 34 e a dos abaixo da de indigência, de 7 para 12. Os $20 \%$ mais pobres da população urbana que em 1981 recebiam $6,9 \%$ da renda total passaram a receber $5,7 \%$ em 1990 e os $20 \%$ mais ricos sobem sua fração de $37,8 \%$ para $44,6 \% .^{201}$

exclusividade de emissão monetária, bem como a forte desconfiança relacionada ao fato de que os bancos privados teriam a obrigação de entregar ao Banco Central as suas reservas de ouro.

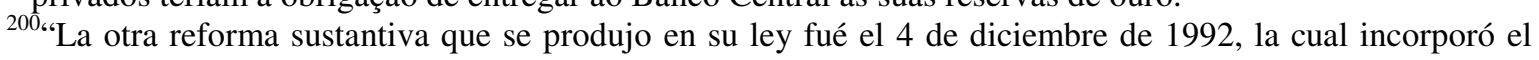
principio de la autonomía en la administración del BCV y le dió al Banco Central el carácter de persona jurídica pública de naturaleza única. Asimismo se eliminó el carácter corporativo que hasta la fecha mantenía la composición del Directorio, en su lugar, se estableció un cuerpo colegiado de siete miembros, un Presidente y seis directores, designados por el Presidente de la República por un período de seis años, que evita la coincidencia con los períodos constitucionales. La designación del Presidente se somete a la aprobación de las dos terceras partes del Senado, mientras que la representación del Ejecutivo en el Directorio se redujó a un Director, el cual en ningún caso puede ser el Ministro de Hacienda. Otro aspecto novedoso que introdujó la reforma fué la prohibición expresa de otorgar crédito directo al Gobierno Nacional, y el establecimiento de una disposición que obliga a la República a reponer el patrimonio del Banco cuando éste incurra en pérdidas debido a la aplicación de sus políticas.” História del BCV (BANCO CENTRAL DE VENEZUELA. Disponível em: <www.bcv.org.ve>).

${ }^{201}$ As reformas neoliberais se iniciam em fevereiro de $1989 \mathrm{com}$ a posse de Pérez $\left(2^{\circ}\right.$ mandato, fevereiro de 1989/94), com desemprego e inflação crescentes e salários reais cadentes. Graças à Guerra do Golfo, no Oriente, os preços do petróleo subiram entre 1989 e meados de 1991, estimulando a economia e saindo da depressão. Mas o fôlego foi curto, dados a forte queda dos preços do petróleo, o aumento da inflação e a queda ainda maior dos salários. A recessão volta mais forte em 1993/97. Nesse clima de tensões ocorrem duas tentativas de golpe militar (fevereiro e novembro de 1992) e a deposição de Pérez (maio/1993), 
O país foi, então, submetido às reformas neoliberais propostas pelo "Consenso de Washington", assim como ocorreu com grande parte dos países latino-americanos que enfrentavam nesse período graves crises financeiras em razão do excessivo endividamento externo. A adesão às diretrizes do Consenso era condição impositiva, sem a qual não haveria a ajuda financeira da mencionada organização internacional.

Tais medidas foram recebidas de maneira muito impopular por toda a nação e o presidente do Banco Central teve contestada a sua forma de atuação, motivo pelo qual foi demitido do cargo (embora tivesse mandato fixo). Houve, a partir daí, a criação de um Comitê de Política Monetária, Cambiária e Financeira ${ }^{202}$ que tinha por objetivo formular as diretrizes da política monetária a ser adotada pelo Banco Central da Venezuela.

O sucessor de Perez, Rafael Caldera Rodríguez (1995-1999), embora tenha criticado a política econômica anterior apresentou, em 1995, seu programa "Agenda Venezuela" (implantado a partir de abril de 1996), com grande apoio de projetos e recursos do BIRD e do FMI, com "novas" propostas de reformas as quais nada mais foram do que a continuidade do processo de implantação das reformas do Consenso de Washington, o que somente contribuiu para o aumento da insatisfação popular e favoreceu fortemente a ascensão do governo populista de Hugo Chávez.

A partir de 1998, com a ascensão de Hugo Chávez ao poder e o denominado "Socialismo do Século XXI", a atuação do Banco Central tornou-se, de fato, "dependente" das vontades do Poder Executivo.

Dado que o governante venezuelano está convencido de que é possível construir na Venezuela o Socialismo do Século XXI, percebe-se que tem elevada importância para esse abstrato projeto o controle estatal de atividades econômicas consideradas estratégicas, caso da telefonia, do setor elétrico e do emissor de moeda, do Banco Central ou das faixas de petróleo pesado ainda não nacionalizadas ${ }^{203}$.

acusado pelo Senado por corrupção. CANO, Wilson. Venezuela: limites para uma nova política econômica. Economia e Sociedade, Campinas, v. 11, n. 1, p. 102, jan./jun. 2002.

${ }^{202}$ Reglamento Interno del Banco Central de Venezuela

Capítulo II - Del Comité Permanente de Políticas Monetaria, Cambiaria y Financiera

Artículo 96.- El Comité Permanente de Políticas Monetaria, Cambiaria y Financiera tiene por objeto deliberar en torno a las propuestas de formulación y aplicación de las políticas económicas que son responsabilidad del Banco Central de Venezuela y hacer el seguimiento de tales políticas adoptadas por el Directorio, así como de los productos institucionales asociados a la agenda de asuntos prioritarios en estas materias; analizar las proyecciones y escenarios de mediano y largo plazo que fundamentarán la estrategia y actuación del Instituto; estudiar lo relativo a la circulación de billetes y monedas; y observar la actuación del Instituto dentro del marco de la coordinación macroeconómica como parte de las políticas públicas tendentes a facilitar el desarrollo ordenado de la economía nacional. Esta norma está disponível no site do BANCO CENTRAL DA VENEZUELA. Reglamento Interno del Banco Central de Venezuela. Disponível em: <http://www.bcv.org.ve/c3/reglabcv.asp>. Acesso em: 17 out. 2009.

${ }^{203}$ VILLA, Rafael. A política externa Venezuelana de Chávez para a América do Sul: entre a ideologização das identidades e as necessidades do pragmatismo. Análise de Conjuntura, n. 10, Observatório Político Sul- 
Em 1999, nesse contexto de reformas para o novo regime imposto por Chávez foi realizada uma Assembleia Nacional Constituinte da qual sobreveio uma nova constituição com muitas mudanças no quadro institucional do país, dentre as quais, cabe destacar a alteração do nome do país para República Bolivariana de Venezuela; eliminação do Senado, tendo sido criada uma Assembleia Nacional Unicameral e uma Câmara Constitucional para interpretar a nova Constituição; houve a substituição de vários titulares de altos postos tais como os do Conselho Nacional Eleitoral, do Tribunal Supremo de Justiça, da Promotoria Pública, do Tesouro, vários juízes da Corte Superior e outros; houve também a criação do chamado "Poder Moral", como uma agência adicional do governo, composto pelo Ministério Público, Controladoria Geral da República e Defensoria do Povo, para fiscalizar a administração pública contra atos que atentem a ética e a moral; por fim, passou a ser permitida a reeleição do presidente com ampliação do novo mandato ${ }^{204}$. Estava, então, coroada a perpetuação de Hugo Chávez no poder.

No que tange especificamente à formulação e execução da Política Monetária, a nova Constituição da Venezuela ${ }^{205}$ manteve não só a estabilidade de preços como objetivo fundamental, como também a autonomia do Banco Central para a formulação e exercício das políticas de sua competência.

O artigo 319 da nova Constituição Venezuelana subordina a atuação do Banco Central ao princípio da responsabilidade pública, de forma que tenha de prestar contas à Assembleia Nacional e expedir informes periódicos que permitam sua avaliação. Nesse sentido, está expresso na constituição que o não cumprimento das metas sem causa justificada ensejará remoção da diretoria bem como penalidades administrativas a seus diretores.

Americano - Instituto Universitário de Pesquisas do Rio de Janeiro IUPERJ/UCAM, outubro/2007, p. 4. Disponível em: <www.observatorio.iuperj.br>.

${ }^{204}$ CANO, Wilson. op. cit., p. 117.

${ }^{205}$ Sección Tercera: del Sistema Monetaria Nacional

Artículo 318. Las competencias monetarias del Poder Nacional serán ejercidas de manera exclusiva y obligatoria por el Banco Central de Venezuela. El objeto fundamental del Banco Central de Venezuela es lograr la estabilidad de precios y preservar el valor interno y externo de la unidad monetaria. La unidad monetaria de la República Bolivariana de Venezuela es el bolívar. En caso de que se instituya una moneda común en el marco de la integración latinoamericana y caribeña, podrá adoptarse la moneda que sea objeto de un tratado que suscriba la República. El Banco Central de Venezuela es persona jurídica de derecho público con autonomía para la formulación y el ejercicio de las políticas de su competencia. El Banco Central de Venezuela ejercerá sus funciones en coordinación con la política económica general, para alcanzar los objetivos superiores del Estado y la Nación. Para el adecuado cumplimiento de su objetivo, el Banco Central de Venezuela tendrá entre sus funciones las de formular y ejecutar la política monetaria, participar en el diseño y ejecutar la política cambiaria, regularla moneda, el crédito y las tasas de interés, administrar las reservas internacionales, y todas aquellas que establezca la ley. 
A respeito da coordenação das políticas econômicas, a constituição (art. 320) dispõe sobre a responsabilidade de o Estado promover e defender a estabilidade econômica e velar pela estabilidade de preços para o bem-estar social. Além disso, está claramente expressa na constituição a não subordinação do Banco Central ao Poder executivo, de forma que aquele não possa contribuir com eventual política fiscal deficitária que este venha a adotar. Artículo 320. El Estado debe promover y defender la estabilidad
económica, evitar la vulnerabilidad de la economía y velar por la
estabilidad monetaria y de precios, para asegurar el bienestar social.
El ministerio responsable de las finanzas y el banco Central de Venezuela
contribuirán a la armonización de la política fiscal con la política
monetaria, facilitando el logro de los objetivos macroeconómicos. En el
ejercicio de sus funciones; el Banco Central de Venezuela no estará
subordinado a directivas del Poder Ejecutivo y no podrá convalidar o
financiar políticas fiscales deficitarias.

La actuación coordinada del Poder Ejecutivo Central de Venezuela se dará mediante un acuerdo anual de políticas, en el cual se establecerán los objetivos finales de crecimiento y sus repercusiones sociales, balance externo e inflación, concernientes a las políticas fiscal, cambiaria y monetaria; así como los niveles de las variables intermedias e instrumentales requeridos para el alcanzar dichos objetivos finales. Dicho acuerdo será firmado por el Presidente o Presidenta del Banco Central de Venezuela y el o la titular del ministerio responsable de las finanzas, y divulgará en el momento de la aprobación del presupuesto por la Assemblea Nacional. Es responsabilidad de las instituciones firmantes del acuerdo que las acciones de política sean consistentes con sus objetivos. En dicho acuerdo se especificarán los resultados esperados, las políticas y las acciones dirigidas a lograrlos. La ley establecerá las características del acuerdo anual de política económica y los mecanismos de rendición de cuantas. (Grifou-se)

Assim, nos termos do artigo 320 da Constituição, por meio de um acordo anual de política econômica, o Banco Central da Venezuela e o Poder Executivo definem os objetivos da política monetária, cambial e fiscal especificando os resultados esperados e quais serão as ações voltadas ao seu alcance. O artigo $321^{206}$ dispõe sobre um fundo de estabilização macroeconômica que visa controlar os gastos do Estado em âmbito nacional, regional e municipal.

\footnotetext{
${ }^{206}$ Artículo 321. Se establecerá por ley un fondo de estabilización macroeconómica destinado a garantizar la estabilidad de los gastos del Estado en los niveles nacionales, regional y municipal, ante las fluctuaciones de los ingresos ordinarios. Las reglas de funcionamiento del fondo tendrán como principios básicos la eficiencia, equidad y no discriminación entre las entidades públicas que aporten recursos al mismo.
} 
Desta breve análise da Constituição da Venezuela, promulgada durante o governo de Chávez, é curioso constatar que, embora se trate de uma constituição demasiado extensa, contendo princípios da chamada democracia participativa e sob a égide de um regime dito "revolucionário" e "bolivariano", nela estão expressos alguns dos princípios de economia monetária dos estados tipicamente liberais, tais como formulados por Milton Friedman, o maior defensor do ideal neoliberal de todos os tempos. São, por exemplo, matéria de disposição constitucional a manutenção da estabilidade monetária acima de todas as coisas e o forte controle dos gastos fiscais e dos déficits públicos, conforme propugna a primeira diretriz do Consenso de Washington ${ }^{207}$ : 1 . Disciplina fiscal, por meio da qual o Estado deve limitar seus gastos à arrecadação, eliminando o déficit público.

Em 2007, Hugo Chávez propôs uma nova reforma constitucional que, entre outras, apresentava as seguintes alterações: i) a reeleição contínua e a ampliação do mandato presidencial de seis para sete anos; ii) criação de um poder popular formado por Conselhos Comunais; iii) criação das Forças Armadas bolivarianas, que deveriam ser formadas para lutar contra o imperialismo; e especialmente, no que tange ao tema ora tratado, iv) o fim da autonomia e a retirada do poder de decisão do Banco Central em controlar as reservas internacionais.

No referendo, a população venezuelana rejeitou a reforma constitucional proposta pelo presidente Hugo Chávez. Nesse sentido, ao menos formalmente, o Banco Central continua independente ${ }^{208}$.

\footnotetext{
${ }^{207}$ Diretrizes fixadas pelo Consenso de Washington:

1. disciplina fiscal, através da qual o Estado deve limitar seus gastos à arrecadação, eliminando o déficit público;

2. focalização dos gastos públicos em educação, saúde e infra-estrutura;

3. reforma tributária que amplie a base sobre a qual incide a carga tributário, com maior peso nos impostos indiretos e menor progressividade nos impostos diretos;

4. liberalização financeira, com o fim de restrições que impeçam instituições financeiras internacionais de atuar em igualdade com as nacionais e o afastamento do Estado do setor;

5. taxa de câmbio competitiva;

6. liberalização do comércio exterior, com redução de alíquotas de importação e estímulos á exportação, visando a impulsionar a globalização da economia;

7. eliminação de restrições ao capital externo, permitindo investimento direto estrangeiro;

8. Privatização, com a venda de empresas estatais;

9. Desregulação, com redução da legislação de controle do processo econômico e das relações trabalhistas; 10. Propriedade intelectual.

${ }^{208}$ Recentemente, em 05.11.2009, foi aprovada a reforma da Lei do Banco Central da Venezuela na qual se verifica a alteração de uma série de artigos que versam sobre a atuação do Banco Central, tais como os tipos de operações que podem ser feitas com as instituições financeiras e de que maneira deverá prestar contas ao Poder Executivo, sem no entanto prever alterações em relação a sua condição de instituição independente. "Gaceta Oficial N. ${ }^{\circ} 39.300$ de fecha 05 de noviembre de 2009, la Ley de Reforma Parcial de la Ley del Banco Central de Venezuela. Esta nueva Ley de Reforma presenta un conjunto de modificaciones en los siguientes artículos: 48, 56, 58, 75, 113, 114, 115”.
} 
Do exposto, observando-se o cenário atual em que se encontra a Venezuela, verifica-se que não só a independência consiste em mera formalidade disposta na própria Constituição Federal do país, mas também a própria democracia.

De todo modo, constata-se que a atuação do Banco Central vem sendo manipulada para contribuir com os interesses da República Bolivariana, sejam eles quais forem. Isso porque os rumos da Venezuela sob o comando de Hugo Chávez ainda não estão claros: ao mesmo tempo em que se exalta o "Socialismo do Século XXI", verifica-se o bojo de uma Constituição que mais parece, ao menos no que tange à administração da política econômica, uma cartilha neoliberal.

\subsubsection{Banco Central da Argentina}

O Banco Central da Argentina foi criado pela reforma monetária e bancária de 1935, a qual extinguiu a Caixa de Conversão vigente desde 1899. O idealizador dessa instituição foi Raúl Prebisch, economista respeitado no país e primeiro diretor geral do Banco Central. O renomado economista constituiu um Banco voltado a encampar as novas ideias Keynesianas que fervilhavam na época.

Conforme disposto em sua primeira Carta Orgânica, tratava-se de um Banco Central voltado a promover a liquidez e o bom funcionamento do crédito ${ }^{209}$, proibindo aos bancos a realização de operações que, de alguma forma, comprometessem essa liquidez. Nessa etapa, a Argentina passou por um período de enorme prosperidade em que era comparada aos países mais desenvolvidos da Europa e em contraste com os demais países latino-americanos.

Depois da Segunda Guerra Mundial, iniciou-se um período de muitas mudanças estruturais

que se prolongou até a década de 1990, etapa em que o país enfrentou instabilidades tanto na política quanto na economia. Especialmente depois de 1970, acelerou-se um processo inflacionário incontrolável que culminou na edição da Ley de

\footnotetext{
${ }^{209}$ Informações extraídas do site BANCO CENTRAL DE LA REPÚBLICA ARGENTINA. Disponível em: <www.bcra.gov.br>. Acesso em: 05 nov. 2009.
} 
Convertibilidad $^{210}$ (1991), única ferramenta disponível para enfrentar a hiperinflação que açoitava o país.

Depois de onze anos, esse modelo econômico deixou de existir com a edição da Ley de Emergencia Económica (2002).

Ley de Emergencia Publica Y de Reforma del Régimen Cambiario

Articulo 1 - Declárase, con arreglo a lo dispuesto en el artículo 76 de la Constitución Nacional, la emergencia pública en materia social, económica, administrativa, financiera y cambiaria, delegando al Poder Ejecutivo nacional las facultades comprendidas en la presente ley, hasta el 10 de diciembre de 2003, con arreglo a las bases que se especifican seguidamente:

1. Proceder al reordenamiento del sistema financiero, bancario y del mercado de cambios. 2. Reactivar el funcionamiento de la economía y mejorar el nivel de empleo y de distribución de ingresos, con acento en un programa de desarrollo de las economías regionales. 3. Crear condiciones para el crecimiento económico sustentable y compatible con la reestructuración de la deuda pública. 4. Reglar la reestructuración de las obligaciones, en curso de ejecución, afectadas por el nuevo régimen cambiario instituido en el artículo $2^{\circ}$.

Articulo 2. ${ }^{\circ}$ - El Poder Ejecutivo nacional queda facultado, por las razones de emergencia pública definidas en el artículo $1 .^{\circ}$, para establecer el sistema que determinará la relación de cambio entre el peso y las divisas extranjeras, y dictar regulaciones cambiarias. (grifou-se)

Com efeito, nesta fase em que se declarou emergência pública, a Argentina teve de reestruturar todo o seu sistema de pagamentos com a forte intervenção do Estado na economia e, mais propriamente, na execução da política monetária. E, dessa forma, por meio de políticas tipicamente intervencionistas vem tentando reerguer-se.

Ao contrário do que se espera, da análise das normas especificamente voltadas à regulamentação do Banco Central dada a forte intervenção verificada na economia, verifica-se que a Carta Orgânica atualmente em vigor (Lei 24.144 de 22.10.1992 ${ }^{211}$ ), prevê

\footnotetext{
${ }^{210}$ Sancionada por Ley 23.928, el 27.03.1991, (B.O. 28.03.1991):

Artículo 3. - El BANCO CENTRAL DE LA REPUBLICA ARGENTINA podrá comprar divisas con sus propios recursos o emitiendo los pesos necesarios para tal fin, y venderlas, al precio establecido conforme al sistema definido por el Poder Ejecutivo nacional, con arreglo a lo dispuesto en el artículo $1^{\circ}$ de la Ley de Emergencia Pública y de Reforma del Régimen Cambiario.

Artículo $4 .^{\circ}$ - En todo momento, las reservas del BANCO CENTRAL DE LA REPUBLICA ARGENTINA en oro y divisas extranjeras serán afectadas al respaldo de la base monetaria. Cuando las reservas se inviertan en los depósitos, otras operaciones a interés, o a títulos públicos nacionales o extranjeros pagaderos en oro, metales preciosos, dólares estadounidenses u otras divisas de similar solvencia, su cómputo a los fines de esta ley se efectuará a valores de mercado.

211 A Carta Orgânica do Banco Central da República Argentina, desde a sua edição, passou pelas seguintes alterações: Lei N. ${ }^{\circ}$ 24.144, de 23.09.1992; Decreto N. 1860 de 13.10.1992; Decreto N. ${ }^{\circ} 1887$ de
} 
a independência de forma absoluta, muito maior em comparação aos dois casos analisados - Chile e Venezuela, senão veja-se o disposto no Artigo 3. :

Es misión primaria y fundamental del Banco Central de la República Argentina preservar el valor de la moneda. Las atribuciones del Banco para estos efectos, serán la regulación de la cantidad de dinero y de crédito en la economía y el dictado de normas en materia monetaria, financiera y cambiaria, conforme a la legislación vigente. El Banco Central de la República Argentina deberá dar a publicidad, antes del inicio de cada ejercicio anual, su programa monetario para el ejercicio siguiente, informando sobre la meta de inflación y la variación total de dinero proyectadas. Con periodicidad trimestral, o cada vez que se prevean desvíos significativos respecto de las metas informadas, deberá hacer público las causas del desvío y la nueva programación. El incumplimiento de esta obligación de informar por parte de los integrantes del directorio del Banco Central de la República Argentina será causal de remoción a los efectos previstos en el artículo $9^{\circ}$. En la formulación y ejecución de la política monetaria y financiera el Banco no estará sujeto a órdenes, indicaciones o instrucciones del Poder Ejecutivo nacional. El Banco no podrá asumir obligaciones de cualquier naturaleza que impliquen condicionar, restringir o delegar sin autorización expresa del Honorable Congreso de la Nación, el ejercicio de sus facultades legales. El Estado nacional garantiza las obligaciones asumidas por el Banco. Salvo expresas disposiciones en contrario establecidas por ley, no serán de aplicación al Banco Central de la Republica Argentina las normas, cualquiera sea su naturaleza, que con alcance general hayan sido dictadas o se dicten para organismos de la Administración Pública Nacional, de las cuales resulten limitaciones a la capacidad o facultades que le reconoce la presente Carta Orgánica. (Grifou-se).

Embora exista no artigo acima transcrito a previsão sobre a necessária publicidade do Programa Monetário projetado pelo Banco Central para o ano seguinte, bem como a trimestral prestação de contas, o fato é que não há qualquer relação de hierarquia ou mesmo coordenação formal entre o mencionado órgão e o Poder Executivo e, mais ainda, o Banco Central pode assumir qualquer decisão sem que para isso necessite de autorização do Poder Legislativo, tratando-se de um órgão totalmente independente e segregado no que tange aos demais órgãos da administração pública e, principalmente, no que tange às questões relacionadas com a política monetária. 
A Constituição da Argentina ${ }^{212}$, promulgada dois anos depois, em 22.08.1994, diferentemente do estilo cirúrgico da Constituição da Venezuela, pouco dispõe a respeito da política monetária e do Banco Central delegando ao Congresso a obrigação de não apenas estabelecer "um banco federal responsável pela emissão de moeda", como também "promover a defesa do valor da moeda".

Assim, ao comparar-se a Carta Orgânica do Banco Central e a Constituição, verifica-se que o Congresso Nacional argentino delegou toda a formulação e execução da política monetária ao Banco Central, realizando um controle periódico no que tange ao cumprimento do Programa Monetário definido pelo próprio Banco Central. Nesse sentido conclui-se que ao menos formalmente, o Banco Central seria quase um quarto poder, livre para decidir sobre os temas monetários sem preocupar-se em coordená-los com as diretrizes da política econômica, realmente independente (não somente autônomo).

Da análise desse contexto conjuntural instável, embora esteja expressa a não subordinação do Banco Central da Argentina ao Poder Executivo, a prática demonstra uma realidade totalmente diferente na qual o banco central desse país também falha no teste da independência.

Em 2003, o ministro da fazenda, orientado pelo presidente Nestor Kirchner (2003 a 2006), na tentativa de administrar a política monetária para solucionar a grave crise econômica ${ }^{213}$ enfrentada pelo país, não hesitou em demitir o presidente do banco central, embora este tivesse mandato fixo -, porque ele discordava das determinações emanadas do Poder Executivo.

\footnotetext{
${ }^{212}$ Articulo 75 - Corresponde al Congreso: (...)

6. Establecer y reglamentar un banco federal con facultad de emitir moneda, así como otros bancos nacionales. (...)

11. Hacer sellar moneda, fijar su valor y el de las extranjeras; y adoptar un sistema uniforme de pesos y medidas para toda la Nación. (...)

19. Proveer lo conducente al desarrollo humano, al progreso económico con justicia social, a la productividad de la economía nacional, a la generación de empleo, a la formación profesional de los trabajadores, a la defensa del valor de la moneda, a la investigación y al desarrollo científico y tecnológico, su difusión y aprovechamiento.

${ }^{213}$ "El Estado se Queda con Cuatro de Cada Cinco Pesos del Crédito Bancario"- Cuatro de cada cinco pesos que prestan los bancos terminan financiando al Estado, y sólo uno, el restante, se destina al crédito al sector público. Esa es la conclusión de un análisis que dio a conocer hoy la consultora Finsoport, que dirige el ex viceministro de economía Jorge Todesca. Según la consultora, entre el 25 de agosto y el 25 de septiembre, el 36 por ciento de los fondos aplicados por las entidades financieras se destinaron a darle préstamos al sector público. Pero a eso hay que sumar otro $42 \%$ invertido en LEBAC y NOBACS y los depósitos de los bancos en la cuenta corriente del BCRA, otro 6\%. Así, en total, más del $80 \%$ de esos fondos financiaron al Estado". Notícia publicada em 10.07.2009 no site: CLARÍN. Disponível em: <http://www.clarin.com/diario/2009/10/07/um/m-02014146.htm>. Acesso em: 17 out. 2009.
} 
Atualmente, pode-se dizer que a independência do Banco Central Argentino continua com sua eficácia bastante discutível. Cristina Kirchner $^{214}$, sucessora e casada com Nestor Kirchner, deu continuidade às políticas de seu marido e vem enfrentando uma série de dificuldades financeiras. Embora pareça estar tentando reconstruir suas relações internacionais e buscar um novo caminho para o desenvolvimento, o cenário atual leva a crer que a Argentina está na iminência de enfrentar uma grave crise institucional e de governabilidade.

Em mais uma demonstração de que essa independência seria somente formal, no dia 07.01.2010 o presidente do Banco Central da Argentina, Martín Redrado foi pressionado a renunciar o cargo por ter descumprido ordem do Poder Executivo. A origem conflito foi motivada pela necessidade de financiamento do governo que se encontra às voltas com uma possível moratória. Redrado negou a solicitação de US\$ 6,5 bilhões das reservas internacionais para pagar títulos da dívida externa com vencimento em 2010, evitando o uso de dinheiro do orçamento, tendo sido, por esse motivo, acusado de ter descumprido as orientações do governo e não ter tomado providências para transferir as reservas a uma conta especial do Tesouro.

Ante à pressão para que renunciasse e recorrendo à independência do Banco Central, Martin Redrado resistiu e manteve-se no cargo, apesar de Cristina Kirchner já ter inclusive convidado o economista Mario Blejer para assumi-lo.

Nos termos da Lei Orgânica do Banco Central, com mandato de seis anos, Matin Redrado, como toda a diretoria do banco, somente poderia sair mediante processo por improbidade administrativa com o aval de uma comissão mista do Congresso, encabeçada pelo presidente do Senado (artigo $9^{\circ}$ da Lei Orgânica ${ }^{215}$ ). Sem observar a necessidade de

\footnotetext{
${ }^{214}$ El actual gobierno argentino de Cristina Fernández de Kirchner está recibiendo los coletazos políticos de la resaca de crecimiento, cuya consecuencia más preocupante es la inflación, y un contexto externo más delicado debido a la crisis de las hipotecas en los Estados Unidos y su repercusión en los mercados globales. A eso se suma el absurdo crecimiento de los precios de los alimentos en los últimos meses, que obligó a la actual presidente a subir los impuestos a las exportaciones agrícolas, lo que despertó disputas con los sectores ruralistas, ya incubadas anteriormente, durante el mandato de Néstor Kirchner. La Argentina del siglo XXI está exhibiendo sus más profundas contradicciones sociales, que deben ser comprendidas también a partir de su propia trayectoria histórica y política. JAVIER, Vadell. La Argentina de Kirchner: el retorno del Estado en el siglo XXI y sus implicaciones en la política externa.Observatorio Político Sul-Americano. Instituto Universitário de Pesquisas do Rio de Janeiro IUPERJ/UCAM. Disponível em: <www.observatorio.iuperj.br>.

${ }^{215}$ ARTICULO $9^{\circ}$ : Los integrantes del directorio podrán ser removidos de sus cargos, por el Poder Ejecutivo Nacional, por incumplimiento de las disposiciones contenidas en la presente Carta Orgánica o por incurrir en alguna de las inhabilidades previstas en el artículo anterior.

La remoción de los miembros del directorio será decretada por el Poder Ejecutivo Nacional cuando mediare mala conducta o incumplimiento de los deberes de funcionario público, debiéndose contar para ello con el
} 
chancelar sua decisão com o Congresso (inclusive pelo fato de que a maioria é oposição), Cristina Kirchner, por meio de um Decreto 18/2010 216 de necessidade e urgência (equivalente à medida provisória do Brasil) demitiu Martín Redrado por "incorrer em má conduta e descumprir deveres de funcionário público".

Em 08.01.2010 Martín Redrado foi reconduzido ao cargo por decisão judicial que, além disso, suspendeu os efeitos do decreto que determinou a utilização das reservas. Por se tratar de uma crise bastante recente, não é possível prever quais serão seus desdobramentos e se prevalecerá a força política do Poder Executivo ou a Lei Orgânica do Banco Central, agora respaldada pelo Poder Judiciário. Todavia, pode-se entender como positiva a atitude de Redrado ao tentar fazer cumprir a Lei invocando a independência do Banco Central.

\subsubsection{Considerações Gerais sobre os Bancos Centrais da América Latina}

Da escolha dos países latino-americanos que de alguma forma poderiam servir como modelo ou de inspiração para o Brasil, nota-se que, salvo alguns episódios similares na história de um e outro país, cada um deles vive realidade bastante distinta, o que dificulta uma comparação eficiente quanto ao exercício de suas políticas monetárias.

O Chile, que mais tardiamente livrou-se da ditadura militar e sempre sustentou seu comércio internacional apoiado na parceria comercial com os Estados Unidos, possui um banco central relativamente independente e vem galgando bons patamares de desenvolvimento, tratando-se de verdadeiro expoente no cenário latino-americano atual.

A Venezuela, tão rica em recursos naturais, desde 1998 é governada por um presidente que pretende instaurar o "Socialismo do Século XXI" no país e vem, aos

previo consejo de una comisión del Honorable Congreso de la Nación. La misma será presidida por el presidente de la Cámara de Senadores e integrada por los presidentes de las comisiones de Presupuesto y Hacienda y de Economía de la misma y por los presidentes de las comisiones de Presupuesto y Hacienda y de Finanzas de la Cámara de Diputados de la Nación. (Grifou-se)

${ }^{216}$ Decreto $18 / 2010$

CONSIDERANDO: (...)

Que, a pesar de los dispositivos legales citados, a la fecha no se ha ejecutado la norma por la actitud remisa del Señor Presidente del BANCO CENTRAL DE LA REPUBLICA ARGENTINA, quien públicamente ha manifestado que no la ejecutaría y de hecho parece no tener reparo en omitir, rehusar o retardar el cumplimiento de la norma cuyo cumplimiento le concierne. (...)

Artículo $1^{\circ}$ - Remuévese del cargo de Presidente del BANCO CENTRAL DE LA REPUBLICA ARGENTINA al Licenciado D. Hernán Martín PEREZ REDRADO (DNI No 14.610.971), por incurrir en mala conducta e incumplimiento de los deberes de funcionario público. 
poucos, transformando-o numa "nova Cuba". Seu Banco Central é formalmente independente, todavia no mundo fático essa independência não se concretiza, pois o cenário político atual assemelha-se muito ao de uma ditadura em que seu governante controla, de forma não democrática, os principais centros de decisão.

A Argentina também vive uma situação bastante particular no cenário latinoamericano, mergulhada numa profunda crise financeira não superada desde a "dolarização crônica" de sua economia ${ }^{217}$. Seu passado de progresso e desenvolvimento, quando era comparada a países como a Suíça, ficou esquecido.

Esta análise, por sua vez, foi proveitosa ao possibilitar a percepção de que o modelo de independência funciona perfeitamente bem, até que ocorra um fato econômico relevante que obrigue o Poder Executivo a interferir em sua atuação.

Isso leva a duas outras conclusões: (i) a primeira de que a atuação do Banco Central está intrinsecamente ligada às questões políticas da vida da nação, não é à toa que sua função é a de desempenhar o papel de executor da política monetária, não havendo como desvencilhar esta atividade isolando-a como se fosse totalmente técnica e (ii) especialmente no que concerne aos países em desenvolvimento, há outras questões estruturais mais profundas a serem resolvidas antes que se chegue a aventar a hipótese da autonomia, tais como o amadurecimento/resgate de suas democracias, o desenvolvimento de políticas públicas básicas, a diminuição dos índices de desemprego, a diminuição da corrupção, entre outros.

De todo modo, os acertos e erros cometidos por políticos segundo suas ideologias e interesses não são tão relevantes para o escopo deste trabalho, mas, sim, perceber que o Banco Central vem sendo essencial para a administração das crises pelo Estado e pode assumir papel relevante no desenvolvimento dos países, embora esta ferramenta não venha sendo utilizada de forma adequada em muitos casos.

\footnotetext{
${ }^{217}$ PEREIRA, Luis Carlos Bresser; FERRER, Aldo. Dolarização crônica: Argentina e Brasil. Revista de Economia Política, São Paulo, v. 11, n. 1, jan./mar. 1991, neste artigo os autores destacam que a dolarização crônica é um fenômeno tipicamente argentino, cujo componente básico é a utilização do dólar como indexador, destacam que após sucessivas crises enfrentadas na década de 1980, este método foi utilizado como meio de controlar a inflação galopante, não tendo gerado os efeitos esperados. (...) "enquanto isso, subsiste o dilema argentino de como retomar o crescimento da economia. Em médio e longo prazos, é provavelmente impossível estabilizar os preços, aumentar a demanda por dinheiro em moeda nacional e eliminar a dolarização crônica num contexto de estagnação e de deterioração permanentes, p. 13.
} 


\subsection{Constatações e Perspectivas}

Diversos autores, ao tratarem da questão da autonomia do Banco Central, apenas tangenciam o tema principal em detrimento de questões meramente formais, tais como: se o presidente tem mandato fixo, se a independência é formal ou operacional, se existe alguma interferência externa na tomada de decisões, se há controle prévio ou posterior etc.

No entanto, o verdadeiro cerne dessa questão reside em compreender o escopo da política monetária, vale dizer, se, de fato, o Banco Central deve buscar exclusivamente alcançar uma meta quantitativa de inflação sem observar qualquer outra variável, conforme propunham Milton Friedman e seus seguidores monetaristas, ou, se o Banco Central deve, precipuamente, tomar decisões voltadas à redução do desemprego coordenadamente com os objetivos traçados pelo Estado de Direito, conforme teorizou John Maynard Keynes.

Para chegar-se a uma conclusão adequada, outras questões devem ser respondidas antes:

- quais são os fins do Estado de Direito: controlar a inflação ou proporcionar desenvolvimento sustentado para a sociedade, com pleno emprego?

- o que está na carta constitucional dos países que elegem a estabilidade monetária como prioridade enquanto fica evidente a deterioração social a qual enfrentam?

- qual o papel reservado para o Banco Central no contexto jurídico-institucional do Estado de Direito?

De acordo com os estudos empreendidos para este trabalho, não há outra conclusão mais lógica senão a de que o Banco Central deve estar em consonância com os objetivos do Estado proporcionando condições adequadas de desenvolvimento para a sociedade - é esse o seu papel.

O Banco Central, no atual estágio de evolução em que se encontra, corresponde à instituição de maior relevância nos sistemas financeiros dos países contemporâneos. A política monetária e creditícia que desenvolve e a fiscalização e o controle das instituições bancárias privadas é essencial para a política econômica dos governos.

Nesse sentido, por uma questão de coerência, as prioridades, os objetivos e as metas formuladas para a atuação do Banco Central devem ser estabelecidos em observância às previsões normativas coordenadas e fiscalizadas pelo Estado. É preocupante, para dizer o 
mínimo, verificar que em muitos países, inclusive aqueles menos desenvolvidos, existe a priorização do controle da inflação como meta primordial e que esta, na maioria das vezes, é a principal justificativa de um banco central independente, a defesa apresentada para que esse órgão possa atuar livre das "amarras".

É inevitável perceber que a observância das metas inflacionárias está, muitas vezes, acima da busca pelo pleno emprego, do incentivo ao empreendedorismo por meio da concessão de créditos mais baratos, do desenvolvimento e do estabelecimento de um sistema financeiro seguro e transparente que possibilite a evolução dos mercados financeiros e de capitais, além de diversos outros objetivos que o Banco Central como órgão pertencente à estrutura Estatal deve respeitar.

Metas quantitativas de inflação não são objetivo de política monetária, muito menos "bem público de primeira ordem" tal como defende Lourdes Sola. Com efeito, esse pode ser um meio para que se atinjam alguns dos objetivos mencionados, mas não pode ser a obsessão dos banqueiros centrais, seu medidor de eficiência e reconhecimento. 


\title{
CAPÍTULO III. O ESTADO BRASILEIRO. O BANCO CENTRAL DO BRASIL E A POLÍTICA MONETÁRIA
}

\begin{abstract}
"Assegurar as condições de um aumento elevado e constante da renda nacional per capita aparece hoje em dia, acima das querelas ideológicas e políticas, como a tarefa primeira e indeclinável do Poder Público. Nestas condições, a iniciativa, ou melhor, a responsabilidade do Estado na vida econômica deixa de ser a exceção para transformar-se em princípio." COMPARATO, Fabio Konder. O Indispensável Direito Econômico. ${ }^{218}$
\end{abstract}

\subsection{Introdução}

As transformações socioeconômicas ocorridas com o processo de "desregulação financeira" na década de 1970 reorganizaram a ordem e a conformação das instituições no cenário mundial.

O papel dos Estados passa a ser questionado, bem como a sua soberania tendo em vista a distorcida concepção de que a globalização seria um processo inclusivo e homogeneizador que culminaria com a extinção pacífica dos estados nacionais. Um mundo ideal, sem fronteiras, preconceitos e desigualdades estaria despontando no horizonte. Todavia, por trás dessa ideologia, evidencia-se um fortalecimento dos contrastes, a polarização entre países e classes sociais por meio das quais as relações assimétricas de poder e dominação explicam sua rápida expansão ${ }^{219}$.

O que se viu, a partir de então, foi a mudança de postura especialmente por parte dos Bancos Centrais no exercício da política monetária, que passa a orientar-se de acordo com padrões internacionais de comportamento, alinhados para manter e garantir a estabilidade dos sistemas econômicos, possibilitando a livre e segura circulação e multiplicação de capitais provenientes de riquezas privadas:

(...) desfeitas as fronteiras entre moeda, finanças e capital, as políticas monetárias se transformaram em alavancas simultâneas da competição entre os estados e do jogo especulativo e de acumulação da riqueza abstrata. É desta perspectiva que deve olhar-se para o novo papel dos bancos centrais no jogo e poder e da riqueza mundiais. (...) Mas, tirando o

\footnotetext{
${ }^{218}$ COMPARATO, Fábio Konder. Ensaios e pareceres de direito empresarial. Rio de Janeiro: Forense, 1978. p. 464.

${ }^{219}$ FIORI, José Luís. Globalização, hegemonia e império. In: TAVARES, Maria Conceição; FIORI, José Luís Fiori (Org.). Poder e dinheiro: uma economia política da globalização. São Paulo: Vozes, 1997. v. 1, p. 88.
} 
caso alemão, norte-americano e japonês, os demais Bancos Centrais deixaram de ser instrumentos dos seus estados, mas mantêm-se como "garantidores" das parcelas de riqueza privada mantida dentro de suas jurisdições bancárias. 220

O Estado Brasileiro e, mais especificamente, seu órgão executor de política monetária - o Banco Central do Brasil - não passou ileso por todas essas transformações globais; ao contrário, absorveu a filosofia e vem 'fazendo a lição de casa' de forma exemplar.

Um retrato da economia brasileira atual, a despeito de evidenciar aparente prosperidade $^{221}$, atribuída à redução dos índices inflacionários e à abertura comercial ${ }^{222}$, se analisado com maior profundidade, evidenciará um país com grandes desigualdades sociais e precária distribuição de renda, que cobra altos juros para financiar a atividade produtiva, possui elevado índice de desemprego, uma indústria genuinamente nacional quase inexistente e uma enorme dívida pública interna ${ }^{223}$.

Assim, embora exista um conformismo generalizado com essa política, busca-se neste capítulo analisar, na perspectiva do Estado Brasileiro, qual o verdadeiro papel da política monetária. Para isso, contribui a análise da peculiar história brasileira, fundamentalmente voltada ao mercado externo, bem como a análise da conformação de suas instituições e, principalmente, sobre as bases do arcabouço jurídico que comporta essa realidade fática.

\subsection{O Estado Brasileiro}

Neste primeiro tópico pretende-se empreender um estudo sobre a formação e evolução do Estado brasileiro, para, então, passar-se à análise do Sistema Financeiro Nacional e do papel designado ao Banco Central à luz do arcabouço jurídico especialmente

\footnotetext{
${ }^{220}$ FIORI, José Luís. op. cit., p. 143.

${ }^{221}$ Segundo o Instituto de Pesquisa Datafolha, de acordo com pesquisa realizada entre 14 e 18 de dezembro de 2009, $72 \%$ dos brasileiros consideram o governo Lula bom ou ótimo.

${ }^{222}$ A abertura comercial em 1990 ao mercado internacional teve como consequência direta a entrada de uma avalanche de bens de consumo importados, supostamente hábeis a melhorar a qualidade de vida dos consumidores trazendo a sensação e inclusão por parte da pequena camada social dos brasileiros com acesso a tais produtos.

${ }^{223}$ Conforme informação disponível no sítio do Banco Central, a dívida pública interna bruta do país em outubro de 2009 era de $\mathrm{R} \$ 1,98$ trilhão de reais, correspondendo a 66,8\% do Produto Interno Bruto (PIB). BANCO CENTRAL DO BRASIL. Composição da DLSP. Disponível em: <http://www.bcb.gov.br/?COMPDLSP>. Acesso em: 26 dez. 2009.
} 
voltado para a regulamentação de suas atividades, com o objetivo precípuo de desvendar qual a sua missão em termos de política monetária.

\subsubsection{As Conformações Históricas do Estado Brasileiro}

Este estudo inicial, sobre as conformações históricas do Estado brasileiro, certamente deverá corroborar para a compreensão das características adquiridas pelo Banco Central, os motivos que levaram à sua atual configuração e, principalmente, sobre o seu papel no contexto econômico e social do país. Nesse sentido, serão utilizados como ponto de apoio, inclusive para as referências aos fatos históricos, alguns dos principais estudiosos do tema, tais como Raymundo Faoro, Sérgio Buarque de Holanda e Celso Furtado $^{224}$.

O Brasil, país de proporções continentais, é o único de colonização portuguesa da América do Sul, único a continuar monarquista após a conquista da independência, um país que pode ser retratado por sua história um tanto peculiar, se analisado comparativamente aos demais países americanos de colonização espanhola e anglosaxônica.

Como se sabe, este país não logrou, assim como os demais países latinoamericanos, o mesmo sucesso em termos de desenvolvimento comparado ao dos países norte-americanos. Nesse sentido, buscar entender as raízes dos problemas sociais que permearam essa história é um bom ponto de partida para o estudo que se deseja empreender.

As razões aventadas para explicar o subdesenvolvimento latino-americano face ao extenuante desenvolvimento das colônias do Norte, por parte dos estudiosos do tema, são diversas e muitas delas bastante pitorescas (para não dizer puramente preconceituosas), tais como: condições climáticas que influenciariam o comportamento indolente ou pujante do povo; a inferioridade cultural e religiosa dos ibéricos e católicos em relação aos anglosaxões protestantes; o fato de ter-se constituído no Sul da América uma nação mestiça sem

\footnotetext{
${ }^{224}$ Embora sejam de correntes de pensamentos distintas e formações diferentes, todos esses autores de expressivo relevo apresentam uma visão bastante analítica a respeito da formação do Brasil a qual será bastante proveitosa ao estudo que se pretende empreender.
} 
identidade cultural própria; a natureza da colonização de acordo com o perfil dos colonizadores.

Não há dúvidas de que uma conjunção complexa de motivos levou a América Latina ao atraso em termos de crescimento econômico e evolução social. Não existe um único motivo, tampouco uma razão lógica capaz de elucidar essa questão. Todavia, entre as razões mencionadas acima, possui embasamento a questão da colonização versus exploração, vale dizer, a diferença do tipo de colonização, de acordo com o perfil dos colonizadores.

Enquanto os colonizadores anglo-saxões foram em busca de uma nova pátria, para se instalarem definitivamente com suas famílias, os ibéricos basearam sua atividade exploratória no extrativismo vegetal e mineral. Tudo o que aqui encontravam de mais rico transportavam até o país de origem. Logo, a explicação sobre o atraso da América Latina estar relacionado, também, com a sua abundante riqueza inicial.

Com efeito, não há como fugir da assertiva de que os ingleses eram, em verdade, "colonizadores", enquanto os ibéricos eram "conquistadores"225. Certamente, essa diferenciação impactou de forma decisiva a evolução das colônias, que trilharam, no Sul e no Norte, caminhos tão distintos.

No Brasil, especialmente, o precário acesso à educação proporcionada a uma pequena parcela da população, adicionado ao fato de a família real portuguesa, quando aqui aportou em 1808, não ter realizado a reforma religiosa do catolicismo, nem a revolução econômica do capitalismo, nem a revolução científica que se esperava, resultou, em larga medida, na falta de consciência sobre os ideais da democracia, na falta de preparo para o regime capitalista e na baixa qualidade crítica de seu povo.

Contribuiu para isso, na origem, a elitização do poder político. Processo que se iniciou com o Brasil Colônia e a instituição das Capitanias Hereditárias ${ }^{226}$, embrião da organização burocrática brasileira. As Capitanias eram grandes pedaços de terras em que se criava um estabelecimento militar e econômico, constituídas com base no sistema político administrativo do reino, dotadas de atributos de autoridade soberana. Eram

\footnotetext{
${ }^{225} \mathrm{Na}$ concepção de SÉRGIO BUARQUE DE HOLANDA, são contrapostos os modelos do "aventureiro/conquistador" e do "trabalhador/colonizador". Aquele possuía uma excepcional adaptabilidade, caracterizava-se por buscar novas experiências, ignorar fronteiras e viver em busca de horizontes distantes. Já este, esforçado, buscava tirar proveito das insignificâncias e ver antes a parte que o todo. HOLANDA, Sérgio Buarque de. Raízes do Brasil. 10. ed. Rio de Janeiro: J. Olympio, 1976. p. 12 e ss.

${ }^{226}$ FAORO, Raymundo. Os donos do poder: formação do patronato político brasileiro. 5. ed. Porto Alegre: Globo, 1979. p. 115 e ss.
} 
inalienáveis e indivisíveis, e o "Capitão e Governador" representava o rei na qualidade de administrador e delegado.

A consequência dessa conformação inicial foi, de um lado, uma enorme concentração de terra nas mãos de poucos representantes da classe dominante, proprietária do latifúndio-mercantil e, de outro, uma enorme quantidade de pessoas que deveriam encaixar-se basicamente em duas categorias, ou eram escravos, ou eram pessoas desprovidas de posses que se tornariam "agregados" aos senhores das terras sem papel definido nessa dinâmica social essencialmente agrária/escravocrata.

A política do clientelismo tem origem justamente em virtude dessa estrutura, que basicamente consiste na relação de dependência entre o proprietário das terras e a classe "agregada" a qual constrói sua vida em torno da fazenda do senhor, protegida por ele e dependente dele, resultando disso que toda a sociedade agrária do período colonial passa a organizar-se segundo a dinâmica do poderoso proprietário de terras, ou, tal como conhecido especialmente na região Nordeste, o senhor de engenho, o coronel ${ }^{227}$.

Roberto Schwartz interpreta esse clientelismo como a política da troca de favores produzida pela estrutura colonial que conformou as bases das relações sociais no Brasil. O cidadão médio, sem função definida, não era nem latifundiário, nem escravo, mas um mero agregado do senhor feudal de quem dependia para subsistir e ascender socialmente.

Esquematizando, pode-se dizer que a colonização produziu, com base no monopólio da terra, três classes de população: o latifundiário, o escravo e o homem livre, na verdade dependente. Entre os primeiros dois a relação é clara, é a multidão dos terceiros que nos interessa. Nem proprietários, nem proletários, seu acesso à vida social e a seus bens depende materialmente do favor, direto ou indireto, de um grande. O agregado é a sua caricatura. O favor é portanto o mecanismo através do qual se reproduz uma das grandes classes da sociedade, envolvendo também outra, a dos que têm. Note-se ainda que entre essas duas classes é que irá acontecer a vida ideológica regida em conseqüência por este mecanismo. Assim, com mil formas e nomes o favor atravessou e afetou no conjunto a existência nacional ressalvada sempre a relação produtiva de base, esta assegurada pela força. Esteve presente por toda parte, combinando-se às mais variadas atividades, mais ou menos afins dele, como administração,

\footnotetext{
${ }^{227}$ Sobre o clientelismo, esclarece JAGUARIBE, Hélio. Condições institucionais do desenvolvimento. Rio de Janeiro: Instituto Superior de Estudos Brasileiros, 1958. p. 21: Nessa estrutura-tipo, em que temos a classe dominante de latifúndio-mercantil, a classe dominada do campesinato e a classe média marginal, inaugurase e se configura o processo político determinado pelas próprias condições reais desse meio, o da política de clientela. Em torno das fazendas, constituídas como núcleos econômicos e políticos da vida brasileira, organizavam-se as clientelas dos fatores dependentes da produção desta fazenda, dos homens que se achavam em dependência com o proprietário da terra. (...) processo que se formara desde o Império, da política de favor, mediante uma barganha entre uma classe dominante que obtinha os votos de seu eleitorado, com a promessa do emprego de favor que devolvia em paga a eleição.
} 
política, indústria, comércio, vida urbana, corte etc. Mesmo profissões liberais, como a medicina, ou qualificações operárias, como a tipografia que na acepção européia não deviam nada a ninguém, entre nós eram governadas por ele. E, assim como o profissional dependia do favor para o exercício de sua profissão, o pequeno proprietário depende dele para a segurança de sua propriedade, e o funcionário para o seu posto. $\mathrm{O}$ favor é a nossa mediação quase universal. ${ }^{228}$

Com efeito, apesar de paulatinamente na história do Brasil terem sido galgadas conquistas como a independência do Brasil, o fim da escravatura, e, posteriormente, a redução do analfabetismo e a universalização do voto, a elite que se perpetuou no poder foi aquela mesma que se consolidou nas origens, herdeira dos donatários das capitanias, fundada no tradicionalismo, no particularismo e no clientelismo.

No Brasil o latifundiário era o político, o protetor, o apaziguador que reinava absoluto desde o início, nas terras sem lei do Brasil Colônia fazia as vezes do próprio Estado, manipulando resultado de eleições ${ }^{229}$, decidindo sobre o certo e o errado e criando as próprias leis, enfim, fazendo as vezes de um estado que era, na prática, ausente. Manipulando as soluções de acordo com os interesses particulares.

Nos Estados Unidos, desde os primórdios da colonização, as instituições são o resultado de negociações políticas que protegem a propriedade privada, respeitam contratos e leis garantindo o funcionamento impessoal da justiça. Ao comparar as duas nações em formação, Brasil e Estados Unidos, Celso Furtado ${ }^{230}$ destaca:

As diferenças sociais, entretanto, eram profundas, pois, enquanto no Brasil a classe dominante era o grupo dos grandes agricultores escravistas, nos EUA uma classe de pequenos agricultores e um grupo de grandes comerciantes urbanos dominavam o país. Nada é mais ilustrativo desta diferença do que a disparidade que existe entre os dois principais intérpretes dos ideais das classes dominantes nos dois países: Alexander Hamilton e o visconde de Cairu. Sem embargo, enquanto Hamilton se transforma em paladino da industrialização, mal compreendida pela classe de pequenos agricultores norte-americanos, advoga e promove uma decidida ação estatal de caráter positivo - estímulos diretos às indústrias, e não apenas medidas passivas de caráter protecionista -, Cairu crê

\footnotetext{
${ }^{228}$ SCHWARZ, Roberto. As idéias fora do lugar. In: Ao vencedor as batatas. São Paulo: Duas Cidades, 1992. p. 153.

${ }^{229} \mathrm{O}$ mundo rural era o reino dos coronéis que dominavam os partidos republicanos estatais e davam sustentação ao governo federal e estabilidade à república oligárquica. Este mundo, assim como essa república, da qual estavam excluídos $95 \%$ dos cidadãos, nada tinham de moderno. Era um mundo de analfabetismo, de trabalho semi-servil, de ausência de direitos, de paternalismo. CARVALHO, Murilo de. Pontos e bordados: escritos de história e política. Belo Horizonte: UFMG, 1999. p. 116.

${ }^{230}$ FURTADO, Celso. Formação econômica do Brasil. 31. ed. São Paulo: Companhia Ed. Nacional, 2003. p. 152.
} 
supersticiosamente na mão invisível e repete: "Deixai fazer deixar passar, deixar vender".

Com efeito, a interpretação literal da teoria Smithiana sobre a "mão invisível" poderia induzir à passividade uma vez que o mercado "automaticamente" conduziria a organização das relações econômicas, mas não foi assim que Hamilton desvendou a mensagem de Adam Smith. A indústria norte-americana somente se desenvolveu de forma tão vigorosa e desde o início, graças à política adotada pelo Estado que priorizou a construção de uma infraestrutura adequada para propiciar a industrialização e, diretamente, fomentou o desenvolvimento da atividade industrial.

Naquele país, o Estado desde o início teve por missão garantir a prestação de serviços públicos de qualidade para a maioria da população, não somente por uma elite, além de estimular o desenvolvimento industrial. Daí se verificou a conjunção de diversos fatores tidos como ideais para a consolidação do regime capitalista.

Conforme relata Furtado, já em 1655, Massachusetts editou uma lei que obrigava todas as famílias a produzirem os tecidos de que fossem precisar. Muitas outras colônias proibiam a exportação de certas matérias-primas para possibilitar que fossem manufaturadas internamente, como é o caso do couro. Esse tipo de incentivo certamente impulsionou o precoce desenvolvimento industrial norte-americano.

Enquanto nos Estados Unidos ${ }^{231}$ se deu o surgimento simultâneo da democracia e do capitalismo, no Brasil esses conceitos, em larga medida, não foram completamente assimilados por seus líderes. Ao analisar-se a dimensão política do subdesenvolvimento brasileiro verifica-se que a modernização chegou sem que houvesse as necessárias rupturas com as estruturas socioeconômicas arcaicas, perpetuando-se a reprodução do status quo com o passar das décadas.

Como regra, os países da América Latina, e o Brasil não foi exceção, passaram por alguns processos de transformação de forma brusca, como se engolissem um "pacote pronto", vindo de fora. O próprio capitalismo como regime econômico é o melhor exemplo disso.

\footnotetext{
${ }^{231}$ Quando os republicanos falavam em América, era especialmente aos Estados Unidos que se referiam. Esse país representava o espírito de iniciativa, o liberalismo econômico, o federalismo, o industrialismo, o pragmatismo, em oposição ao paternalismo, ao protecionismo, ao centralismo, ao ruralismo, ao bacharelismo da sociedade monárquica. CARVALHO, Murilo de. op. cit., p. 110.
} 
A sociedade, as pessoas e as instituições brasileiras, ainda sob a égide do mercantilismo colonial da matriz, não estavam preparadas para o capitalismo que se formou com base num movimento social da magnitude da Revolução Industrial, da qual emergiu a necessidade de alterar a ordem social, um sentimento geral que deveria trazer renovação. Não havia aqui nenhum sentimento similar a esse, não havia uma população consciente de seus direitos, com ideais, com o espírito de formar e consolidar uma nação e de rejeitar soluções prontas e não pensadas de acordo com as particularidades brasileiras. Ao contrário, houve apenas a absorção passiva de uma estrutura toda montada lá fora ${ }^{232}$.

O povo, passando ao largo de todas essas mudanças, apenas esperava pela política da salvação:

Na base da pirâmide, no outro extremo dos manipuladores olímpicos do poder, o povo espera, pede e venera, formulando a sua política, expressão primária de anseios e clamores, a política da salvação. Confundindo as súplicas religiosas com as políticas, o desvalido, o negativamente privilegiado, identificado ao providencialismo do aparelhamento estatal, com o entusiasmo orgiástico dos supersticiosos, confunde o político com o taumaturgo, que transforme pedras em pães, o pobre no rico ${ }^{233}$.

De acordo com Faoro, o resultado disso foram as velhas mentes que integravam as elites, tratando de novidades as quais não chegaram a compreender. Com isso se explica a perpetuação do "patrimonialismo", o "personalismo"234 e o clientelismo. São os donos das

\footnotetext{
${ }^{232}$ A falta de uma revolução social, a falta de contestação a esses dogmas importados e passivamente absorvidos certamente surtiu efeitos negativos à formação da identidade da nação brasileira. Conforme pontua Ralf Dahrendorf: Os conflitos são indispensáveis, como um fator do processo universal da mudança social. Sempre que falta, são suprimidos ou são resolvidos na aparência, faz-se mais lenta ou detém-se a mudança. Quando se admitem e se regula os conflitos, mantém-se o processo evolutivo como um desenvolvimento gradual. Mas, em todo caso, esconde-se nos conflitos sociais uma excepcional energia criadora de sociedades. Exatamente porque apontam para além das situações existentes, são os conflitos um elemento vital das sociedades, como, possivelmente, seja o conflito um elemento vital de toda a vida. DAHRENDORF, Ralf. Sociedade e liberdade: para uma análise sociológica do presente. Trad. de Vamireh Chacon. Brasília: Ed. da UnB, 1982. p. 82. (Coleção Pensamento Político 16).

${ }^{233}$ FAORO, Raymundo. op. cit., p. 740.

${ }^{234} \mathrm{O}$ "personalismo" é explicado por HOLANDA, Sérgio Buarque de. op. cit., p. 138. Ninguém ignora, porém, que o aparente triunfo de um princípio jamais significou no Brasil - como no resto da América Latina - mais do que o triunfo de um personalismo sobre o outro. É inegável que em nossa vida política o personalismo pode ser em muitos casos uma força positiva e que ao seu lado, os lemas da democracia liberal parecem conceitos puramente ornamentais ou declaratórios, sem raízes fundas na realidade. Isso explica como, entre nós e, em geral, nos países latino-americanos, onde quer que o personalismo - ou a oligarquia, que é o prolongamento do personalismo no espaço e no tempo - conseguiu abolir resistências liberais, assegurou-se por essa forma, uma estabilidade política aparente, mas que de outro modo não seria possível. (...) A idéia de uma espécie de entidade imaterial e impessoal, pairando sobre os indivíduos e presidindo os seus destinos é dificilmente inteligível para os povos da América Latina.
} 
capitanias hereditárias que passaram a ser os políticos eleitos, os burocratas ocupantes de altos cargos nos governos. Esses seriam os “donos do poder" no Brasil ${ }^{235}$.

A comunidade política conduz, comanda, supervisiona os negócios como negócios privados seus, na origem, como negócios públicos depois, em linhas que se demarcam gradualmente. O súdito, a sociedade, se compreendem no âmbito de um aparelhamento a explorar, a manipular, a tosquiar nos casos extremos. Dessa realidade se projeta, em florescimento natural, a forma de poder, institucionalizada num tipo de domínio: o patrimonialismo, cuja legitimidade se assenta no tradicionalismo - assim é porque sempre foi. ${ }^{236}$

De fato, o Brasil, em razão das características de sua colonização e da consolidação de uma elite pouco comprometida com a constituição de uma "nação" e mais apegada à regra do "assim é porque sempre foi", desde o seu descobrimento vem passando por períodos cíclicos de crescimento econômico e crise, sempre de acordo com o que a demanda do mercado internacional exige, sem o estabelecimento de uma gestão responsável para o direcionamento da produção, o fomento de nichos específicos das atividades produtivas, a criação de um mercado interno e uma reflexão sobre as necessidades e carências peculiares à sociedade brasileira.

Do açúcar no Nordeste, ao ouro em Minas Gerais, até o café em São Paulo, do extrativismo à produção agrícola, o Brasil especializou-se de acordo com a demanda externa. Quando, pelo esgotamento da fonte produtora ou pelo excesso de oferta do produto, ocorriam os períodos de crise, ocorria, também, a regressão para uma economia quase de subsistência.

A realidade histórica brasileira demonstrou - insista-se - a persistência secular da estrutura patrimonial, resistindo galhardamente, inviolavelmente, à repetição, em fase progressiva da experiência capitalista. Adotou do capitalismo a técnica, das máquinas as empresas, sem aceitar-lhe a alma ansiosa de transmigrar. (...) Característica principal, a de maior relevância econômica e cultural, será a do predomínio, junto ao foco superior de poder, do quadro administrativo, o estamento que, de aristocrático, se burocratiza progressivamente em mudança de acomodação e não estrutural. O domínio tradicional se configura no patrimonialismo, quando aparece o estado-maior do

\footnotetext{
${ }^{235}$ A democracia no Brasil não condiz com a ideia clássica que pressupõe governo do povo em geral por meio de representantes eleitos. Como produto do clientelismo, os votos foram, por um longo período da história, manipulados de acordo com o resultado almejado pelos grupos oligárquicos, donos do poder, sendo bastante usual a formação de verdadeiros "currais eleitorais" em determinadas regiões do Brasil. Essa realidade prolongou-se até muito recentemente e, ainda hoje, existem indícios que apontam para a manipulação de resultados e compras de votos, bem como a perpetuação de políticos no poder os quais permanecem alheios aos anseios da população e voltados ao interesse de seu restrito grupo.

${ }^{236}$ FAORO, Raymundo. op. cit., p. 733.
} 
comando do chefe, junto à casa real, que se estende sobre o largo território, subordinando muitas unidades políticas. Sem o quadro administrativo, a chefia dispersa assume caráter patriarcal, identificável no mando do fazendeiro, do senhor de engenho e dos coronéis ${ }^{237}$.

Assim, as teorias importadas das nações industrializadas penetraram no Brasil por meio das universidades e, transformadas em doutrina, não encontraram resistência mediante um necessário confronto com a realidade particular. Como se verá na sequência, os frutos dessa herança são colhidos até hoje.

Enquanto isso, o nosso direito pátrio absorvia paulatinamente os princípios mais evoluídos de liberdade e igualdade, os quais apenas formalmente se consolidariam. A realidade de sua aplicação mostra-se bastante díspar daquilo que era consignado no papel. Veja-se, nesse sentido, Raymundo Faoro ${ }^{238}$ :

O regime autoritário convive com a vestimenta constitucional, sem que a lei maior tenha capacidade normativa, adulterando-se no aparente constitucionalismo - o constitucionalismo nominal, no qual a Carta Magna tem validade jurídica, mas não se adapta ao processo político, ou o constitucionalismo semântico, no qual o ordenamento jurídico apenas dê poder aos detentores autoritários. (...) Em última análise, a soberania popular não existe, senão como farsa, escamoteação ou engodo.

E Sérgio Buarque de Holanda ${ }^{239}$ :

Em verdade, o racionalismo excedeu os seus limites somente quando, ao erigir em regra suprema os conceitos assim arquitetados, separou-os irremediavelmente da vida e criou com eles um sistema lógico, homogêneo, a-hitórico. Nesse erro se aconselharam os políticos e demagogos que chamam atenção freqüentemente para as plataformas, os programas, as instituições como únicas realidades verdadeiramente dignas de respeito. Acreditam sinceramente que da sabedoria e sobretudo da coerência das leis depende diretamente a perfeição dos povos e dos governos. Foi essa crença, inspirada nos ideais da Revolução Francesa, que presidiu toda a história das nações ibero-americanas desde que se fizeram independentes. Emancipando-se da tutela das metrópoles européias, cuidaram elas em adotar, como base de suas cartas políticas, os princípios que se achavam então na ordem do dia. As palavras mágicas de Liberdade, Igualdade, Fraternidade sofreram a interpretação que pareceu ajustar-se melhor aos nossos velhos padrões patriarcais e coloniais, e as mudanças que inspiraram foram antes de aparato do que de substância.

\footnotetext{
${ }^{237}$ FAORO, Raymundo. op. cit., p. 736.

${ }^{238}$ Id. Ibid., p. 741-742.

${ }^{239}$ HOLANDA, Sérgio Buarque de. op. cit., p. 134.
} 
Do exposto, verifica-se que os países da América Latina, com destaque para o Brasil, desde a sua origem, representados pelas elites historicamente no poder, vêm tentando acompanhar o ritmo imposto pelas sociedades mais desenvolvidas, absorver seus princípios, entender seus mecanismos e, de alguma forma, adaptá-los a realidades completamente distintas. Enquanto o povo ${ }^{240}$, alienado e ignorante sobre os seus direitos, segue vivendo em condições pouco dignas.

Do exposto verifica-se que uma adequada reflexão sobre qualquer aspecto que envolva a sociedade brasileira deve, necessariamente, considerar as características iniciais de seu desenvolvimento as quais refletem alguns aspectos conjunturais até hoje muito marcantes nas estruturas que a conformam.

Algumas das principais questões contemporâneas podem ser explicadas com base nessa origem, tais como (i) a inexpressiva integração regional entre os países latinoamericanos, os quais sempre estiveram voltados aos interesses dos pólos mais desenvolvidos; (ii) a inexpressiva integração regional quando consideradas as regiões do Brasil, pois cada uma delas desenvolveu-se numa fase da história, de acordo com os interesses do mercado externo, de modo que não houve a consolidação de uma identidade nacional integrada e cooperativa, mas a formação de pólos específicos de desenvolvimento em detrimento da marginalização/abandono de certas regiões; (iii) a tardia industrialização, a qual foi retardada, entre outras causas, em razão da predominância dos interesses das poderosas oligarquias agrárias, tendo sido possível somente a partir da década de $1930 \mathrm{em}$ razão da profunda crise do café, conforme adiante será explicado; (iv) o conturbado processo de democratização do Brasil (verificado também em quase todos os outros países latino-americanos), o que certamente encontra suas mais profundas raízes na formação do seu povo de origem escrava, analfabeta e alienada, dominado por uma pequena elite aristocrática; (v) a dificuldade em formar um corpo técnico burocrático capaz de administrar instituições sem observar interesses particulares, favorecimento de determinados grupos e apadrinhamento de poucos privilegiados (como seria típico do clientelismo anteriormente explicado), ilustrada neste trabalho pela dificuldade em instituir um Banco Central em detrimento dos interesses do Banco do Brasil; (vi) a absorção sem filtro de certas ideologias importadas as quais comprometem a soberania e o

\footnotetext{
${ }^{240} \mathrm{~A}$ idéia de povo era puramente abstrata, a idéia de povo. O povo era na maior parte hostil ou indiferente ao novo regime, e nenhum esforço foi feito para incorporá-lo ao sistema político por meio do processo eleitoral. A república brasileira foi uma originalidade: não tinha povo. CARVALHO, Murilo de. op. cit., p. 120.
} 
desenvolvimento sustentado, como o recente processo de abertura dos mercados em razão da 'globalização financeira' ${ }^{241}$, fruto da ideologia neoliberal corporificada, nos países subdesenvolvidos, pelo Consenso de Washington e formalizada pelos acordos celebrados com o Fundo Monetário Internacional, entre tantas outras.

Com base nessa breve análise das origens da nação brasileira, seguindo o método adotado no primeiro capítulo, será feito um corte para o século $\mathrm{XX}^{242}$, especialmente para a década de 1930, a partir da qual será analisada a conformação do Estado Brasileiro tal como se apresenta hoje.

\subsubsection{Década de 1930 e o Processo de Industrialização}

Na década de 1930 emergiu uma classe média organizada que buscou legitimação de seus direitos. Nessa etapa, a democracia ainda em formação, excluía a grande maioria da população, embora contasse com uma expoente classe média urbana de trabalhadores industriais pouco organizados em termos de representatividade ${ }^{243}$.

Na década de 1930, a burguesia industrial brasileira emergiu como uma verdadeira classe, trazendo em seu bojo uma série de transformações estruturais para o Estado brasileiro, estatuindo novas prioridades na ordem do dia e renovando o corpo burocrático das instituições.

Conforme destaca Gilda Portugal Gouvêa em sua obra sobre as elites burocráticas, quatro matrizes fundadoras são muito importantes para a compreensão da formação da burocracia no Brasil: (i) o fato de que o país atraiu seus conquistadores como colônia de

\footnotetext{
${ }^{241}$ No caso da globalização, o que em geral se vê ocultado pela sua ideologia econômica são as relações assimétricas de poder e dominação e que explicam a sua expansão e a sua originalidade financeira. (...) Pode-se mesmo afirmar que a globalização é um fato, mas só é global do ponto de vista das finanças que passaram a operar num espaço mundial hierarquizado a partir do sistema financeiro norte-americano e viabilizado pela política econômica do estado hegemônico imitada, de imediato, pelos demais países industrializados. FIORI, José Luís. op. cit., p. 88 e 90.

${ }^{242}$ Certamente muitos detalhes específicos da história brasileira foram decisivos para a constituição da nação tal como hoje se apresenta. Uma análise da fase monarquista, dos ciclos econômicos, da mudança de polos de poder entre as regiões Nordeste e Sudeste, das características das principais oligarquias que ocuparam o poder durante os séculos XVII a XIX seria relevante para este estudo, mas poderia alongar em demasia o enfoque histórico do trabalho, e comprometeria e desviaria a atenção do leitor quanto ao tema principal. Daí justificar-se o salto temporal entre um tópico e outro, sem, no entanto, desmerecer a importância dos períodos não especificamente mencionados.

${ }^{243}$ Até a II Guerra, o Brasil era uma sociedade agrária, exportadora de produtos primários, governada por uma oligarquia de grandes proprietários com uma elite europeizada e desdenhosa do grosso da população, formada de pobres, analfabetos e negros. CARVALHO, Murilo de. op. cit., p. 125.
} 
exploração extrativa; (ii) o absolutismo português que centralizava as decisões e impossibilitava que houvesse a formação de um centro legítimo de decisões no Brasil; (iii) um sistema baseado no poder local, que como consequência das duas questões anteriores criou um embrião da administração privada e (iv) um sistema personalizado de relações que deu origem a lealdades fortes com traço de obediência subserviente num primeiro momento e que depois se transformou nas práticas clientelísticas, segundo a autora, fora de controle até hoje.

A questão colocada, na situação brasileira, era como fazer para quebrar a identificação dos interesses do Estado com os de cada segmento oligárquico, situação que imperava no país desde os tempos das capitanias hereditárias.(...) Era um Estado que havia se formado para proteger a livre expansão dos senhores rurais, até o momento em que as condições econômicas e sociais permitiram esta expansão. Mas quando foi chamado para resolver os conflitos abertos entre as oligarquias, mostrou-se ineficiente. E como suas lideranças estavam fracas e "envelhecidas", não foi muito difícil decretar sua falência no início dos $\operatorname{anos} 30 .^{244}$

O fortalecimento do governo central e a formação de uma burocracia ${ }^{245}$ no conceito tradicional weberiano passaram a ser possíveis com o enfraquecimento das lideranças agrárias envelhecidas, dos poderes concentrados localmente devido à exigência da

\footnotetext{
${ }^{244}$ GOUVÊA, Gilda Portugal. Burocracia e elites burocráticas no Brasil. São Paulo: Paulicéia, 1994. p. 78.

${ }^{245}$ MAX WEBER, ao delinear o conceito de burocracia, coloca-a como a forma de organização baseada na racionalidade que tem como objetivo atingir a máxima eficiência em estruturas administrativas (públicas ou privadas). Partiu do conceito de três tipos de autoridade: a tradicional (autoridade adquirida por herança, com procedimentos justificados pelo costume e repetição); carismática (comandos baseados na inspiração do líder) e a racional-legal (procedimentos estruturados em cargos e funções). Utilizou-se desta última autoridade, para desenvolver o conceito de burocracia o qual, em linhas muito gerais, tem como principais características as seguintes: demanda a fixação de normas e regulamentos estabelecidos por escrito, para determinar o seu funcionamento; o trabalho deve ser dividido de maneira que cada um desempenhe sua atividade de forma prévia e claramente definida, para que não haja conflito de competência entre as atividades de um e outro burocrata; os funcionários devem atuar sem se envolver pessoalmente com suas funções, sem impor ao seu cargo características pessoais específicas de sua personalidade; assim o próximo ocupante do cargo não terá dificuldades em desempenhar as mesmas funções. A burocracia é uma organização que estabelece os cargos segundo o princípio da hierarquia. Cada cargo inferior deve estar sob o controle e supervisão de um posto superior. Nenhum cargo fica sem controle ou supervisão. Daí a necessidade da hierarquia da autoridade para fixar as chefias nos diversos escalões de autoridade. Esses escalões proporcionarão a estrutura hierárquica da organização. A hierarquia é o cerne da burocracia, representa ordem e subordinação para o sistema. Todos os cargos estão sujeitos a distintas graduações hierárquicas as quais compreendem privilégios e obrigações, específica e previamente definidos. Para a contratação de novas pessoas para os cargos, é necessário o estabelecimento de critérios de seleção previamente definidos de modo que não sejam observadas atribuições pessoais que transcendam os critérios de competência para o exercício daquela função. WEBER, Max. Historia económica general. Tradução de Manuel Sánchez Sarto. 2. ed. Ciudad de Mexico: Fondo de Cultura Económica, 1956. p. 285 e ss.
} 
burguesia concentrada na região Centro-Sul do país, a qual desejava industrializar-se, mas, para isso, necessitava do incentivo de um estado forte ${ }^{246}$.

São desse período a intensa urbanização da população, o início da industrialização, especialmente na região Sudeste que demandou grandes movimentos migratórios ${ }^{247}$ vindos majoritariamente da Europa. Além disso, esse momento histórico foi bastante profícuo no campo jurídico, com a conquista de importantes direitos políticos tais como a permissão para mulheres votarem, o voto secreto, além de direitos trabalhistas com a edição da Consolidação das Leis do Trabalho (Decreto-Lei 5452 de 1.․05.1943), a qual regulamentou o horário de trabalho, a obrigatoriedade do pagamento das horas extras, o salário mínimo e o fim do trabalho infantil. Cabe ainda mencionar desse período a edição da Lei da Usura (Decreto 22.626 de 07.04.1933) sobre a qual adiante se discorrerá; Lei das Sociedades por Ações (Decreto-Lei 2627 de 26.09.1940²48), Código de Processo Penal (Decreto-Lei 3.689, de 03.10.1941), Código Penal (Decreto-Lei 2.848 de 07.12.1949), entre outras.

Cumpre destacar que a transformação da sociedade brasileira foi especialmente favorecida por dois fatores principais e, de certa forma, conjugados: a crise de superprodução do café e a Grande Depressão que assolou a economia mundial em 1929.

A economia brasileira esteve sustentada pela cultura do café desde 1840. No fim do século XIX, o Brasil era o principal produtor de café do mundo. As condições favoráveis para o contínuo incremento de sua produção levaram essa mercadoria a começar a apresentar crises de superprodução, além da saturação do mercado mundial que havia atingido seu nível máximo em meados de 1930. Esses fatores traziam como efeito direto a queda do preço do café e os prejuízos de seus, então poderosos, produtores.

Para evitar a decadência daquilo que era tido como a sustentação da economia nacional, a oligarquia cafeeira desenvolveu vários mecanismos de defesa, tais como a

\footnotetext{
${ }^{246}$ A solução encontrada pelas oligarquias dos estados mais desenvolvidos foi a de fortalecer o Governo Federal, tanto política quanto econômica administrativamente, para que fosse capaz de se impor àquelas oligarquias descompassadas com a nova realidade. E o Estado que nascia apresentava-se com propostas de intervenção direta na vida econômica, a começar pelo comércio internacional, principalmente no que se refere ao café, o mais importante produto de exportação. GOUVÊA, Gilda Portugal. op. cit., p. 79 e ss.

${ }^{247}$ Entre 1884 e 1920 , três milhões de imigrantes entram no país, a maioria italianos. Destes, $60 \%$ dirigem-se para São Paulo causando profundas alterações demográficas. A capital do Estado entra em processo de crescimento e rivaliza com o Rio de Janeiro em produção industrial. Forma-se lá uma classe industrial mais aguerrida sob a influência do anarco-sindicalismo. CARVALHO, Murilo de. op. cit., 108.

${ }^{248}$ Revogada pela atual Lei 6404/1976.
} 
depreciação da moeda nacional nos momentos de queda dos preços de exportação e a compra dos excedentes da produção pelo Estado, financiado por empréstimos externos ${ }^{249}$.

Assim, em vez de buscar medidas para se evitarem novas crises de produção em excesso, e incentivar a diversificação do plantio de outras culturas, o Estado incentivava a produção interna de café por meio de tais medidas protecionistas. Conforme aponta Celso Furtado, essas medidas protecionistas por parte do Estado, que visavam apenas à manutenção do status quo, acabaram por proporcionar ao Brasil, justamente nessa fase de crise, a possibilidade de elevar-se ao patamar de país industrializado enquanto todos os demais países enfrentavam os efeitos da Grande Depressão com o recrudescimento de sua produção industrial.

A política de defesa do café por parte do Estado, ao incentivar a produção por meio de medidas protecionistas, mesmo que não houvesse demanda por esse produto, contribuiu para manter o preço do café nos patamares usualmente praticados, o que evitou o desequilíbrio na balança de pagamentos, mesmo no cenário de grande depressão global vivida na época.

O mecanismo de valorização consistia em retirar do mercado, mediante compra, certa quantidade de café reputada suficiente para manter um preço adequado pela conseqüente normalização da oferta e da procura. As parcelas do produto assim retiradas seriam, posteriormente, vendidas na medida em que se sucedessem safras menos volumosas, com o objetivo de manter o equilíbrio entre a oferta e a procura ${ }^{250}$.

Além disso, a significativa depreciação da moeda em razão da crise na agricultura de exportação tornou elevados os preços dos bens de capital importados. Nesse sentido, a nascente classe industrial nacional encontrou, no mercado interno, a demanda por bens de capital produzidos no Brasil já que importá-los havia ficado muito caro. De forma não planejada, com o objetivo de proteger o café, o Estado criou o cenário ideal para impulsionar o processo de industrialização brasileiro.

Cria-se, em conseqüência, uma situação praticamente nova na economia brasileira, que era a de preponderância do setor ligado ao mercado interno no processo de formação de capital. A precária situação de economia

\footnotetext{
${ }^{249}$ Acordo formalizado pelo Convênio de Taubaté em 1906. Sobre essa política protecionista adotada pelo Estado, LAFER, Celso. O sistema político brasileiro: estrutura e processo. São Paulo: Perspectiva, 1978. p. 73. O relativo sucesso inicial desta política estimulou internamente a produção de café, o que gerou problemas ainda mais complexos de superprodução e levou, a longo prazo, a plantações de café no resto do mundo, fazendo com que o Brasil perdesse sua capacidade monopolística de manobrar o mercado internacional, reduzindo conseqüentemente as possibilidades de ação unilateral.

${ }^{250}$ VENÂNCIO FILHO, Alberto. op. cit., p. 93.
} 
cafeeira, que vivia em regime de destruição de um terço do que produzia, com baixo nível de rentabilidade, afugentava desse setor os capitais que nele ainda se formavam. E não apenas os lucros líquidos, pois os gastos de manutenção e reposição foram praticamente suprimidos. A capacidade produtiva dos cafezais foi reduzida a cerca da metade, nos quinze anos que se seguiram à crise. Restringida a reposição, parte dos capitais que haviam sido imobilizados em plantações de café foi desinvertida. (...) $\mathrm{O}$ crescimento da procura de bens de capital, reflexo da expansão da produção do mercado interno e a forte elevação dos preços desses bens, acarretada pela depreciação cambial, criaram condições propícias à instalação no país de uma indústria de bens de capital. Esse tipo de indústria encontra, por uma série de razões óbvias, sérias dificuldades para instalar-se numa economia dependente. (...) Ora as condições que se criaram no Brasil nos anos 30 quebraram este círculo. A procura de bens de capital cresceu exatamente numa etapa em que as possibilidades de importação eram as mais precárias possíveis ${ }^{251}$.

Verifica-se, portanto, a partir de 1930, uma clara ruptura daquele modelo primário exportador, em favor de um modelo de desenvolvimento industrializado e voltado às necessidades do mercado interno. Pode-se dizer que essa década foi a década da "grande transformação" da economia brasileira. Uma nova estrutura político-social embasada nos novos interesses dominantes passou a ocupar o poder: era a nascente elite industrial e urbana. A partir desse período, iniciaram-se as reformulações das instituições que compunham a administração burocrática do Estado, processo que culminaria, já em 1960, com a estruturação do Sistema Financeiro Nacional.

\subsubsection{O Estado Brasileiro entre 1930 e 1980}

Entre 1930 e 1970 floresceu no país um progresso econômico de caráter desenvolvimentista fomentado pelo Estado que investiu em grandiosas obras de infraestrutura e no incremento da indústria de base. Nesse período, verificou-se a

\footnotetext{
${ }^{251}$ FURTADO, Celso. op. cit., p. 277-280. E, nesse mesmo sentido, JAGUARIBE, Hélio. op. cit., p. 16: A crise que afeta o café brasileiro no período dos anos 20, provoca, finalmente, a distorção da nossa economia e a transformação da nossa estrutura-tipo. (...) O Brasil deixou assim de ser um país semicolonial, como havia sido até por volta dos anos 30, para entrar numa fase de transformação, caracterizada pela enérgica e acentuada propensão ao desenvolvimento, embaraçada, no entanto, por alguns pontos de estrangulamento. Estes pontos de estrangulamento são, no nível econômico, a crise do intercâmbio exterior, que continua a subsistir; a crise nas relações entre a infra e a superestrutura econômica no Brasil, motivada pelo fato de que a produção de bens e serviços de base, como energia elétrica, transportes, aço etc. é inferior às necessidades de consumo, o fato de que o nosso processo de acumulação de poupanças não se faz de forma satisfatória, o que explica a nossa subcapitalização, agravada pela circunstância de que a propensão a um consumo em faixa superior à produção de bens e serviços conduz a uma inflação que ameaça tornar-se galopante.
} 
consolidação das classes urbanas, o planejamento estatal da economia e a consolidação da indústria brasileira. No cenário político, o Brasil passou por momentos que se alternaram de democráticos populistas a ditatoriais, entre os quais os mais significativos foram a "Era Vargas", o Governo de Juscelino Kubitschek e a Ditadura Militar a partir de 1964.

Duas características marcantes podem ser ressaltadas nesse período: Estado forte e atuante na economia e financiamento dos investimentos direcionados à industrialização e suportados por créditos advindos do mercado externo. No plano das políticas públicas, pregou-se o desenvolvimento econômico como grande objetivo a ser perseguido ${ }^{252}$. Essa doutrina do necessário e urgente desenvolvimento econômico tornou-se motivo de segurança nacional. Era preciso desenvolver o Brasil, garantir a soberania, integrar as regiões por meio da promoção do desenvolvimento.

Quanto ao financiamento desse desenvolvimento pelo mercado externo, com efeito, desde o final da década de 1950 até meados de 1970, o mercado financeiro internacional estava ávido por realizar investimentos além de suas fronteiras e os países em desenvolvimento foram destinatários de grande quantidade de créditos. Foi nesse período que o Brasil se capitalizou.

O dimensionamento apresentado pelas economias dos países industrializados a partir da segunda metade do século XX, o interesse político cada vez maior em se determinarem áreas de influência econômica, sobretudo do aspecto comercial, e a necessidade de expansão a níveis internacionais pelas empresas já dimensionadas em grande escala, aliados ao imperativo do desenvolvimento econômico, colocada para os países considerados, então, subdesenvolvidos, com economias predominantemente voltadas para as atividades primárias, apresentandose esses países, no cenário mundial, como carentes de recursos financeiros e de bens (de consumo, inicialmente), ensejaram a migração internacional de capitais pelos países deles necessitados e que neles viam a alternativa obrigatória para a consecução do desenvolvimento de suas economias, por outro ${ }^{253}$.

O período do "Milagre Econômico", financiado à custa do endividamento externo, embora tenha trazido grandes benefícios para as classes de maior renda, com o auge do incremento industrial do Brasil e dos índices produtivos, trouxe também, em termos

\footnotetext{
${ }^{252}$ A Emenda Constitucional n. ${ }^{\circ} 1$ à Constituição Federal de 1967 assim dispunha em seu artigo 8. ${ }^{\circ}$ : Art. 8. ${ }^{\circ}$ Compete à União:

$\mathrm{V}$ - planejar e promover o desenvolvimento e a segurança nacionais;

${ }^{253}$ DE CHIARA, José Tadeu. Capitais estrangeiros. Revista de Direito Mercantil, Industrial, Econômico e Financeiro, São Paulo, v. 16, n. 26, p. 67, 1977.
} 
sociais, grandes perdas. No que tange ao bem-estar da população, este milagre não ocorria $^{254}$, valendo a política do "crescer para depois dividir" 255.

Para que se compreenda a dinâmica desenvolvimentista do período, a qual teve por consequência o aumento inflacionário considerável e acabou por gerar uma grave crise institucional, cabe analisar o contexto em que se deu a viabilização do exercício da política monetária na época.

Logo depois da crise de 1929, foi editada a "Lei da Usura" (Decreto 22.626, de 07.04.1933), limitando a taxa de juros ao dobro da taxa legal prevista no artigo 1062 do Código Civil, o qual, por sua vez, estipulava a taxa dos juros moratórios no patamar de $6 \%$ (seis por cento) ao ano. O governo então passou a observar o limite de 12\% (doze por cento) ao ano para a fixação dos juros os quais incidiriam sobre a arrecadação tributária e sobre os títulos da dívida pública.

O que se verificou, na prática, foi a impossibilidade de se exercer essa política de forma adequada ante o arcabouço jurídico brasileiro em vigor no período. Como se sabe, as receitas do Estado, a fim de empreender o desenvolvimento nacional financiando os empreendimentos e estimulando a atividade produtiva, ocorrem, em regra, pelas seguintes vias: (i) arrecadação tributária, (ii) emissão de títulos da divida pública ou (iii) emissão monetária.

No que tange à arrecadação tributária, na medida em que se impunham os limites da usura, todo o crédito público ficava limitado a uma taxa nominal de juros ${ }^{256}$. A inexistência de atualização dos créditos tributários em geral e a cobrança de uma reduzida taxa de juros moratórios a qual não acompanhava a deterioração do poder de compra do instrumento monetário (inflação) possibilitavam ao contribuintes retardar o seu pagamento, pois, ao término do processo de execução fiscal, era possível liquidar o débito com lucro.

\footnotetext{
${ }^{254}$ O salário mínimo real sofreu uma perda de poder aquisitivo de $42 \%$ entre 1964 e 1974, enquanto se registrou, nesse mesmo período, o aumento do número de acidentes de trabalho devido ao excesso de horas extras trabalhadas. A diminuição expressiva do salário do então "chefe de família" fez com que mais integrantes da família passassem a procurar emprego, registrou-se um aumento da mortalidade infantil, e a saúde da maioria da população se deteriorou a ponto de ocorrerem epidemias durante esse período. Houve, enfim, um agravamento de todo o quadro social no país, algo aparentemente incompatível com o enorme aumento da riqueza nacional.

${ }^{255}$ Declaração atribuída a Antônio Delfim Netto, Ministro da Fazenda entre 1967 e 1964.

${ }^{256} \mathrm{O}$ número que expressa a taxa de juros é a taxa nominal, a qual não se altera de acordo com as oscilações do poder de compra do instrumento monetário. Os juros nominais não permitem assegurar a reposição da instabilidade do poder de compra, implicando a deterioração da disponibilidade de crédito. Enquanto o governo ficou atrelado ao nominalismo da taxa de juros e ampliou as despesas com emissão monetária, o sistema bancário encontrou alternativas para negócios e crédito, com a criação de inúmeras tarifas para ampliar a remuneração.
} 
Ou seja, valia muito mais a pena, do ponto de vista financeiro, adiar o pagamento dos impostos até o momento em que o Estado estivesse de posse de um título executivo da dívida.

Quanto aos títulos de emissão da dívida pública, a impossibilidade de atualização de seu valor de acordo com a inflação afastava o interesse de compradores de dívidas do Estado. O advento da Lei da Usura inviabilizou o mecanismo da oferta de títulos públicos de maneira competitiva comparativamente aos títulos privados.

O redesconto, mecanismo de política monetária explicitado no capítulo anterior, também foi utilizado em prejuízo das receitas do Estado. O Banco do Brasil (que na época fazia as vezes de banco central), ao realizar operações de redesconto, que na verdade teria de ter uma característica de punição ao banqueiro em dificuldades, passou a funcionar como fonte de subsídios, devido a baixas taxas cobradas pelo redesconto. Nesse sentido, os bancos utilizavam-se do mecanismo estatal do redesconto e praticavam taxas mais altas no mercado financeiro. Ao que se assistiu foi o Banco do Brasil ser utilizado como fonte de subsídios - os banqueiros tomavam empréstimos do Banco do Brasil a 1\% (um por cento) e repassavam o crédito a taxas maiores ${ }^{257}$.

Assim, a emissão de moeda passou a ser o único mecanismo viável para o financiamento estatal. Esse é o crédito que caracterizou o mecanismo de intermediação financeira entre 1930 e 1960 em razão do tabelamento dos juros, a insuficiência de arrecadação e a impossibilidade de financiamento por títulos da divida pública não monetariamente corrigidos (ambas por limitação dos juros).

Nesse sentido, verifica-se que há toda uma distorção no mercado creditício no qual a inexistência de um mecanismo corretor do valor da moeda num estado inflacionário levou à situação em que a captação de dinheiro somente era conseguida de forma eficiente pelo Estado com emissão de moeda, a qual, grosso modo, foi um dos fatores que alimentavam, mais e mais, o aumento da crise inflacionária, vez que não havia o incremento da capacidade produtiva suficiente para absorver o volume de emissão monetária.

\footnotetext{
${ }^{257}$ Disto decorria que o recurso do redesconto se traduzia numa alternativa vantajosa para as instituições bancárias que assim se viam geralmente beneficiadas por um lucro oriundo do diferencial dos juros de redesconto em relação aos cobrados nas operações normais. DE CHIARA, José Tadeu. Disciplina jurídica das instituições financeiras, cit., p. 295.
} 
O marco transformador dessa realidade foi a Lei 4.357 de $16.07 .1964^{258}$, que criou títulos da dívida pública sujeitos a reajustes (ORTN). Com isso, surgiram ferramentas para que o Estado pudesse participar da captação de recursos e corrigir déficits fiscais.

Tais títulos públicos eram de longo prazo, sujeitos à atualização nominal, segundo uma metodologia própria - a correção monetária. Essa mesma Lei impôs a correção monetária aos créditos fiscais ${ }^{259}$. Consequentemente, o lançamento das ORTN tornou possível a obtenção de recursos adicionais para a cobertura do déficit além de estimular a poupança, pois com a correção monetária o poder de compra não seria corroído caso o investidor optasse por poupar.

(...) O problema da ausência de um sistema de correção do valor interno da moeda impedia a dinamização de operações destinadas ao financiamento de investimentos a prazos mais longos e, por sua vez, a própria ampliação dos investimentos. Com esses objetivos, vimos surgir a Lei $\mathrm{n}^{\circ}$ 4357, de 16.07.1964, que, autorizando a emissão das Obrigações do Tesouro Nacional, dotou de grande aceitação esses títulos, que puderam se tornar instrumento de eficiente ação dos órgãos diretivos do mercado financeiro, pois com o regime das correções do valor da moeda supriu-se a lacuna já apontada. Esse regime de correção dotou-se nos financiamentos a prazos superiores a 180 dias, viabilizando-se, dessa forma, as operações destinadas ao setor industrial de base, e mobiliário, principalmente ${ }^{260}$.

As ORTN significaram também uma nova forma de endividamento do Estado - de

\footnotetext{
${ }^{258}$ Lei 4357 de 16.07.1964 - Art 1. ${ }^{\circ}$ Fica o Poder Executivo autorizado a emitir Obrigações do Tesouro Nacional até o limite e títulos em circulação de Cr\$700.000.000.000,00 (setecentos bilhões de cruzeiros), observadas as seguintes condições, facultada a emissão de títulos múltiplos: $\S 1^{\circ} \mathrm{O}$ valor nominal das Obrigações será atualizado periòdicamente em função das variações do poder aquisitivo da moeda nacional, de acôrdo com o que estabelece o $\S 1^{\circ}$ do art. $7^{\circ}$ desta Lei.

Art $7^{\circ}$ Os débitos fiscais, decorrentes de não-recolhimento, na data devida, de tributos, adicionais ou penalidades, que não forem efetivamente liquidados no trimestre civil em que deveriam ter sido pagos, terão o seu valor atualizado monetàriamente em função das variações no poder aquisitivo da moeda nacional.

$\S 1^{\circ} \mathrm{O}$ Conselho Nacional de Economia fará publicar no Diário Oficial no segundo mês de cada trimestre civil a tabela de coeficientes de atualização a vigorar durante o trimestre civil seguinte, e a correção prevista neste artigo será feita com base na tabela em vigor na data em que fôr efetivamente liquidado o crédito fiscal. (O $\S 1 .^{\circ}$ foi revogado pelo Decreto-lei 1.281, de 1973, passando a viger em seu lugar a seguinte redação: $\S 1 .^{\circ} \mathrm{O}$ Ministério do Planejamento e Coordenação Geral, de acordo com o artigo $7^{\circ}$, da Lei n. ${ }^{\circ}$ 5.334, de 12 de outubro de 1967, fará publicar, mensalmente, no Diário Oficial, a atualização dos coeficientes de variação do poder aquisitivo da moeda nacional, e a correção prevista neste artigo será feita com base no coeficiente em vigor na data em que for efetivamente liquidado e crédito fiscal.)

${ }^{259}$ Lei 4357 de 16.07 .1964 , artigo $3 .^{\circ}$ - (...) $§ 2^{\circ} .^{\circ}$ A correção prevista neste artigo aplicar-se-á inclusive aos débitos cuja cobrança seja suspensa por medida administrativa ou judicial, salvo se o contribuinte tiver depositado em moeda a importância questionada.

$\S 3 .^{\circ}$ No caso do parágrafo anterior, a importância do depósito que tiver de ser devolvida, por ter sido julgado procedente o recurso, reclamação ou medida judicial, será atualizada monetàriamente, nos têrmos dêste artigo e seus parágrafos.

${ }^{260}$ DE CHIARA, José Tadeu. Disciplina jurídica das instituições financeiras, cit., p. 306.
} 
caráter não inflacionário - e um caminho à indexação da economia ${ }^{261}$. A indexação foi um mecanismo criado para combater a depreciação do poder de compra mediante a alta inflação monetária enfrentada especialmente a partir da década de 1960. A essência desse mecanismo resumia-se a correlacionar a variação da moeda com uma certa quantidade de produto. Durante décadas, o valor do salário mínimo era corrigido segundo seu poder de compra.

O mecanismo de indexação num primeiro momento permitiu que o Estado se socorresse de captações, na medida em que seus títulos poderiam ser negociados sem perda do poder de compra da moeda por estarem indexados. Num segundo momento, a excessiva utilização desse instrumento levou a distorções (decorrentes da metodologia na elaboração desses índices e da sua utilização desmedida e sem critérios).

Com a edição dessa nova Lei, portanto, houve a possibilidade de que o Banco Central passasse a atuar como orientador, controlador das políticas de créditos, pois, a partir daí, os títulos da dívida pública passaram a servir, efetivamente, como instrumento de financiamento do déficit orçamentário, e com possibilidade de serem negociados no mercado bancário (open market).

Todavia a administração da enorme dívida externa, em conjunto com os índices galopantes de inflação, contribuíram decisivamente para uma mudança de orientação no que tange à administração da política monetária. O que pode ser entendido como um desacerto no que tange aos rumos tomados pelo Estado desde então, porque o investimento estatal e a própria emissão monetária não são causadores da inflação que atemorizou a população brasileira no período, conforme pontuou José Carlos de Souza Braga:

A retórica oficial que tem impregnado o debate insiste no caráter inflacionário deste gasto, de uma maneira teoricamente inconsistente. $\mathrm{Na}$ medida em que o gasto público gera demanda efetiva (gasto em consumo e em investimento), contribui para a expansão da massa de salários e

\footnotetext{
${ }^{261} \mathrm{~A}$ indexação compreende o reajuste automático de preços, inclusive salários, em situações inflacionárias com base em determinado índice previamente estipulado. Trata-se de uma solução paliativa utilizada em larga medida no Brasil e que não foi suficiente para conter a inflação e proteger o poder de compra da moeda nacional. COMPARATO escreveu um artigo com um breve resumo a respeito das cláusulas de indexação de preços e concluiu da seguinte maneira: Especificamente no que tange às normas reguladoras de índices de correção monetária, a sua ineficácia é um fenômeno universalmente conhecido e que se realiza com tanto maior intensidade quanto mais desacreditado, perante a opinião pública, seja o Governo ou a política econômica que ele adota. Os Poderes Públicos consideram-se legitimados a tudo fazer, com ou sem amparo legal, para eliminar a inflação, autêntico flagelo social deste século. Mas é verdade que as medidas de ordem jurídica são totalmente impotentes para a cura do mal, quando não associadas à providências de outra natureza, enfeixadas num vasto programa de ação. COMPARATO, Fábio Konder. Cláusulas contratuais de indexação de preços. Revista de Direito Mercantil, Industrial, Econômico e Financeiro, São Paulo, v. 85, p. 46, 1992.
} 
lucros e, portanto, para a ampliação da renda e da riqueza material da sociedade, bem como das receitas públicas. O ponto crucial é o seguinte: se há capacidade produtiva instalada para responder à maior procura por bens de consumo e bens de capital, aquele gasto público não tem por que gerar elevação de preços. Esta só ocorreria no caso de o aparelho produtivo não dispor de capacidade produtiva para responder à maior demanda, com o que ao invés de subir a produção elevar-se-iam os preços. ${ }^{262}$

Com efeito, embora o Estado-Providência tenha sido considerado culpado por todos os males do período e que levou à ascensão da política heterodoxa, o fato é que este movimento no Brasil foi coordenado com transformação do contexto mundial. O neoliberalismo e a globalização financeira impuseram a redução da intervenção estatal em benefício do mercado autorregulável.

A década de 1980 - a chamada "década perdida" - foi o marco que representou o início do declínio dessa política estatal de características intervencionistas e desenvolvimentistas. No cenário político brasileiro e também nas finanças públicas ${ }^{263}$, criou caminho para a abertura comercial consolidada na década seguinte.

Vale destacar como aspectos positivos dessa década a promulgação de uma nova Constituição Federal em 1988; a extinção da Conta-Movimento e do Orçamento Monetário em 1986 (voto CMN n. ${ }^{\circ}$ 45) e a criação da Secretaria do Tesouro Nacional (Decreto 92452 de 10.03.1986). Tais mudanças, as quais serão esmiuçadas adiante, possibilitaram que as contas tanto do Banco do Brasil quanto do Banco Central se tornassem mais transparentes e fosse possível o seu controle ${ }^{264}$.

\footnotetext{
${ }^{262}$ BRAGA, José Carlos de Souza. Os orçamentos estatais e a política econômica. In: BELLUZZO, Luiz Gonzaga de Mello; COUTINHO, Renata. Desenvolvimento capitalista no Brasil: ensaios sobre a crise. 3. ed. São Paulo: Brasiliense, 1984.

${ }^{263}$ No início da década de 80 , o Governo inicia uma tentativa de integração dos orçamentos fiscal e monetário, transferindo alguns gastos, até então financiados pelo orçamento monetário, para o orçamento fiscal e começando a reduzir gradualmente os subsídios diretos e indiretos, via aumento das taxas de juros incidentes sobre os financiamentos concedidos. Além disso, passou-se a consignar no orçamento fiscal dotações para transferências ao orçamento monetário, para quitar responsabilidades do tesouro Nacional junto às Autoridades Monetárias. Com isso, a Conta de Movimento passou a ter uma participação menor no financiamento dos gastos do Banco do Brasil, sendo paulatinamente substituída por suprimentos específicos. JALORETTO, Cláudio. Senhoriagem e financiamento do setor público. 2005. Dissertação (Mestrado) - Universidade de Brasília, UNB, Brasília, 2005. p. 61.

${ }^{264} \mathrm{Foi}$, portanto, nesse período que ocorreu a redistribuição de competências entre essas duas instituições, aproximando o Banco Central do Brasil do perfil de um banco central clássico e afastando o Banco do Brasil de tais atividades para que este ficasse concentrado nos programas oficiais de crédito.
} 


\subsubsection{A Década de 1990 e o Plano Real}

Na década de 1990, ocorreu a abertura comercial no Governo Collor ${ }^{265}$ em virtude do esgotamento do processo de substituição de importações impulsionado pela crescente desregulamentação dos mercados internacionais, redução das tarifas de importação e redução de barreiras comerciais, fruto de um fenômeno complexo de transformação da ordem mundial que envolveu aspectos políticos, econômicos e sociais, batizado de globalização, combinado com o desgaste do modelo do Estado-Providência.

Durante o mandato do Presidente da República Fernando Collor de Mello (1990 a 1992), foram implantados dois planos econômicos: o Collor I e II; ambos implicaram a implantação de medidas de contração monetária e fiscal, reestruturação do arcabouço jurídico para comportar o novo modelo (tema que será tratado a seguir) por meio do confisco dos depósitos à vista e aplicações financeiras dos cidadãos, com prefixação da correção dos preços e salários e reforma administrativa, fechamento de órgãos públicos e demissão de grande quantidade de funcionários.

Tais medidas provocaram a drástica redução da atividade econômica e recessão generalizada, com o aumento do desemprego e queda de salários. Esses fatores conjugados, além da impopularidade da figura do mencionado Presidente em razão do confisco das poupanças e uma série de denúncias de corrupção amplamente divulgadas pela mídia, levaram à sua deposição em 1992, assumindo o seu lugar o Vice-Presidente, Itamar Franco (1992 a1995).

A nova conjuntura política que se instaurou desde então no país e vem-se prolongando sucessivamente na eleição e reeleição de Fernando Henrique Cardoso (1995 a 2002) e, posteriormente, de Luís Inácio Lula da Silva (2003 até a atualidade) consolidou os paradigmas do Estado neoliberal e apoia-se, essencialmente, nas seguintes condições: a Reforma do Estado, a desregulação, privatizações, adoção de uma política de câmbio flutuante, regime de metas de inflação como objetivo da política monetária, controle severo dos gastos públicos e política de geração de superávit fiscal primário.

O arcabouço jurídico brasileiro, para comportar a abertura comercial ao capital estrangeiro iniciada por Collor e enfatizada pelos presidentes seguintes, teve de sofrer

\footnotetext{
${ }^{265}$ LACERDA, Antônio Correa de; BOCCHI, João Ildebrando; REGO, José Marcio; BORGES, Maria Angélica; MARQUES, Rosa Maria. Economia brasileira. 3. ed. São Paulo: Saraiva, 2008. p. 201 e ss.
} 
significativas alterações: a maioria voltada para a desregulamentação da atividade estrangeira e o livre trânsito de capitais internacionais no país, entre elas a própria Constituição Federal com a revogação do artigo $171^{266}$, o qual conferia tratamento privilegiado às empresas de capital nacional com a finalidade de incentivar e promover seu desenvolvimento no país em detrimento das empresas multinacionais igualando as condições entre a incipiente empresa nacional e a empresa estrangeira.

Outro aspecto que reflete essa nova estrutura está no abandono das disposições da Lei 4.131/62 que disciplina a aplicação do capital estrangeiro e as remessas de valores para o exterior, o que gerou o consequente afrouxamento de controles de capital estrangeiro ${ }^{267}$ os quais passaram a gozar de benefícios fiscais e a não ter prazo mínimo de permanência em investimentos no país. Essa medida gerou um ostensivo ingresso de capitais financeiros de natureza especulativa, os quais, ao mínimo rumor de crise, evadem-se em busca de portos mais seguros.

Essas transformações nos mercados financeiros ocorridas nas últimas duas décadas estão submetendo, de fato, as políticas macroeconômicas nacionais à tirania de expectativas volúveis. (...) Países com passado monetário turbulento precisam pagar elevados prêmios de risco para refinanciar seus déficits em conta corrente. Isto representa um sério constrangimento ao raio de manobra da política monetária além de acuar a política fiscal pelo crescimento dos encargos financeiros nos orçamentos públicos ${ }^{268}$.

\footnotetext{
${ }^{266}$ Art. 171. São consideradas (Revogado pela Emenda Constitucional n. ${ }^{\circ}$ 6, de 1995):

I - empresa brasileira a constituída sob as leis brasileiras e que tenha sua sede e administração no País;

II - empresa brasileira de capital nacional aquela cujo controle efetivo esteja em caráter permanente sob a titularidade direta ou indireta de pessoas físicas domiciliadas e residentes no País ou de entidades de direito público interno, entendendo-se por controle efetivo da empresa a titularidade da maioria de seu capital votante e o exercício, de fato e de direito, do poder decisório para gerir suas atividades.

$\S 1^{\circ}$ - A lei poderá, em relação à empresa brasileira de capital nacional:

I - conceder proteção e benefícios especiais temporários para desenvolver atividades consideradas estratégicas para a defesa nacional ou imprescindíveis ao desenvolvimento do País;

II - estabelecer, sempre que considerar um setor imprescindível ao desenvolvimento tecnológico nacional, entre outras condições e requisitos:

a) a exigência de que o controle referido no inciso II do "caput" se estenda às atividades tecnológicas da empresa, assim entendido o exercício, de fato e de direito, do poder decisório para desenvolver ou absorver tecnologia;

b) percentuais de participação, no capital, de pessoas físicas domiciliadas e residentes no País ou entidades de direito público interno.

$\S 2 .^{\circ}$ - Na aquisição de bens e serviços, o Poder Público dará tratamento preferencial, nos termos da lei, à empresa brasileira de capital nacional.

${ }^{267}$ Referida norma confere definição restrita ao conceito de capital estrangeiro a qual é orientada de acordo com o desenvolvimento de atividade produtiva no país. Nos termos de seu artigo primeiro constitui-se o capital estrangeiro em: bens, máquinas e equipamentos entrados no país, sem dispêndio inicial de divisas, destinado à produção de bens ou serviços, bem como os recursos financeiros ou monetários introduzidos no país para aplicação em atividades econômicas.

${ }^{268}$ BELLUZZO, Luiz Gonzaga de Mello. Dinheiro e as transfigurações da riqueza. In: FIORI, Maria Conceição Tavares; José Luiz (Org.). Poder e dinheiro: uma economia política da globalização. São Paulo: Vozes, 1997. v. 1, p. 186-187.
} 
Essa nova conjuntura política tem como efeitos o baixo crescimento da atividade produtiva nacional, o desemprego e a precarização das condições de trabalho ${ }^{269}$.

Muito mais do que isso, houve também uma mudança substancial nas relações jurídicas estabelecidas entre o Estado e os cidadãos. Por causa das privatizações das estatais, o Estado passou a regular a prestação dos serviços públicos pelas empresas privadas.

A lógica da "Reforma do Estado" ocorrida entre 1995 e 2002, conforme pontuam Bercovici, Massonetto e Andrade ${ }^{270}$, imitou a estrutura administrativa norte-americana ao instituir as "agências reguladoras" como os órgãos públicos responsáveis pela fiscalização dos serviços.

Nessa nova sistemática, a preocupação do Estado está com a eficiência e o resultado, sua atuação passa a ser pautada pela dinâmica do mercado. O cidadão torna-se o "usuário" ou o "cliente". Nesse sentido, verifica-se uma verdadeira distorção do sistema. O Estado mínimo apenas físcaliza os serviços e o cidadão assume a posição de consumidor.

A fim de compreender o contexto dessas distorções criadas pelo Estado Neoliberal, especialmente no âmbito da política monetária, cabe analisar o plano econômico que concebeu a nova moeda: o Real.

Com efeito, foram inúmeros planos econômicos e os padrões monetários utilizados pelo Brasil ${ }^{271}$ na tentativa de colocar em prática as teorias desenvolvidas pelos principais economistas nacionais e internacionais sobre como conter a inflação econômica, problema que dominou com especial ênfase a década de 1980 gerando forte recessão, somente superada na década seguinte, por meio do Plano Real ${ }^{272}$ implantado em $1 .^{\circ}$ de julho de

\footnotetext{
${ }^{269}$ “Na fase pós-Real a inflação caiu, o ambiente econômico tornou-se mais estável e previsível, mas a equação básica do crescimento não foi solucionada. Como a capacidade instalada não cresceu o quanto deveria, qualquer movimento de crescimento de consumo foi abortado por medidas de restrição ao crédito, elevação de juros e aumento dos empréstimos compulsórios, de forma que o crescimento tornou-se um subproduto, não o objetivo principal da política econômica”. LACERDA, Antônio Correa de; BOCCHI, João Ildebrando; REGO, José Marcio; BORGES, Maria Angélica; MARQUES, Rosa Maria. op. cit., p. 238.

${ }^{270}$ BERCOVICI, Gilberto; MASSONETTO, Luís Fernando; ANDRADE, José Maria. Reforma do Estado, prestação de serviços públicos, contribuições especiais e federalismo. Revista do Instituto de Pesquisas e Estudos, Bauru, v. 40, n. 45, p. 176, jan./jun. 2006.

${ }^{271}$ Cruzeiro (1942), Cruzeiro Novo (1967), Cruzeiro (1970), Cruzado (1986), Cruzado Novo (1989), Cruzeiro (1990) e Cruzeiro Real (1993) e Real (1994). Fonte: Banco Central do Brasil (www.bacen.gov.br)

${ }^{272}$ Uma grande inovação do plano Real foi a adoção de uma moeda transitória, a Unidade Real de Valor que nunca chegou a circular e possibilitou a implantação da nova moeda, o Real. A Medida Provisória n. ${ }^{\circ}$ 434, de 27 de fevereiro de 1994, dispunha em seu artigo $1 .^{\circ}$ sobre a instituição da URV, dotada de curso legal para servir exclusivamente como padrão de valor monetário, ou seja, foi criada uma moeda exclusivamente
} 
$1994^{273}$, ainda no governo de Itamar Franco.

Quinze anos depois, pode-se dizer que os objetivos do Plano Real foram, em certa medida, alcançados. Hoje o país possui uma moeda relativamente forte, se comparada às anteriores e uma taxa de inflação controlada, porém mantém a taxa de juros em altos patamares. A pergunta que se pode fazer depois desse período de implantação do Plano Real e de seu relativo "sucesso" é a que custo se deu a sua implantação? Abaixo serão aventadas algumas possíveis respostas.

Conforme lecionam BELLUZZO e ALMEIDA $^{274}$, a tática utilizada para a implementação desse plano seguiu uma receita básica para dar fim às grandes inflações que de forma recorrente prejudicaram as economias dos países no século XX: recuperar a confiança no valor da moeda por meio da garantia de seu valor no exterior. O valor da moeda no exterior era garantido por meio da estabilização da taxa de câmbio nominal garantida por financiamento em moeda estrangeira e/ou por um montante de reservas capaz de desestimular a especulação contra a paridade cambial escolhida.

Ao seguir essa estratégia, BELLUZZO e ALMEIDA apontam alguns erros de percurso que, se tivessem sido observados, poderiam ter levado a um plano efetivamente bem-sucedido em termos de estabilização monetária coordenado com desenvolvimento social.

A seguir, serão ordenados da forma em que aparecem na obra dos mencionados autores:

(i) o aumento da dívida pública (não houve preocupação por parte das autoridades monetárias em coordenar as políticas macroeconômicas para proteger as finanças públicas e reorganizar as contas do governo);

para servir com um padrão monetário, não podendo ser utilizada como meio de pagamento. Essa solução foi pensada de modo que a passagem da URV para o Real pudesse ser feita sem problemas de ordem jurídica, especialmente no que tange à conversão dos contratos. A expressão "curso legal" no entendimento enunciado por De Chiara, carrega intrinsecamente duas funções básicas do instrumento monetário: a de noção de padrão de valor e a de meio de pagamento. O truque, portanto, era atribuir à URV o papel de moeda e não de indexador, porque isso garantiria a preservação do direito adquirido nos contrato quando chegasse o momento da conversão monetária. Além disso, o cálculo do poder de compra embutido na URV poderia ser transferido automaticamente para a moeda que mais tarde entraria em circulação com o nome de real. PRADO, Maria Clara do. A real história do real: uma radiografia da moeda que mudou o Brasil. Rio de Janeiro: Record, 2006. p. 193.

${ }^{273}$ Medida Provisória n. ${ }^{\circ}$ 542, de 30 de junho de 1994, convertida na Lei 9.069, de 29 de junho de 1995.

${ }^{274}$ BELLUZZO, Luiz Gonzaga de Mello; ALMEIDA, Júlio Gomes de. Depois da queda: a economia brasileira da crise da dívida aos impasses do Real. Rio de Janeiro: Civilização Brasileira, 2002. p. 363 e ss. 
(ii) a utilização excessiva da âncora cambial (e a posterior adoção do câmbio flutuante), quando, na verdade, a experiência mostra que a taxa de câmbio fixa é o regime ideal nas hiperestabilizações. Se paulatinamente o plano tivesse migrado para o regime de taxa de câmbio fixa, mantendo a abertura comercial, seriam reduzidos progressivamente os diferenciais de inflação e de taxas de juros entre o país e o resto do mundo, vale dizer, a redução do risco cambial dos ativos determinaria maior integração entre os mercados financeiros nacional e internacional, diminuindo o risco dos ativos de emissão brasileira. Todavia, como o regime adotado foi o de conversibilidade limitada com taxas semifixas, a taxa de juros básica da economia manteve-se demasiadamente elevada (entre as mais elevadas, observando-se os padrões mundiais);

(iii) a execução do programa de estabilização foi feita de acordo com as imposições dos mercados financeiros liberalizados ${ }^{275}$. Para atrair os capitais externos era necessária uma oferta de ativos atraentes que prometessem elevados ganhos de capital (o suficiente para compensar o risco de se investir num país com uma moeda recém-estabilizada), tais como: títulos de dívida pública de curto prazo e com elevada liquidez; ações de empresas em processo de privatização, bônus e papéis comerciais de empresas e bancos de boa reputação. Manter esses ativos atrativos implicou manter altas as taxas reais de juros, de acordo com os spreads $^{276}$ exigidos pelos investidores estrangeiros para manterem em sua carteira ativos de uma moeda artificialmente valorizada;

(iv) os dois pontos anteriores, que tinham como mesmo efeito a manutenção da alta taxa de juros, lançaram a economia brasileira numa trajetória de crescimento medíocre (para utilizar a mesma expressão empregada pelos autores), pois ao contrário do processo de endividamento pelo qual o Brasil passou nas décadas de 1960 e 1970, o qual visava substituir importações e estimular exportações,

\footnotetext{
${ }^{275}$ Conforme destacam BELLUZZO, Luiz Gonzaga de Mello; ALMEIDA, Júlio Gomes de. op. cit., p. 374, a estratégia de desenvolvimento associada às recomendações do Consenso de Washington apoiam-se em quatro pilares: a) a estabilidade de preços cria condições para o cálculo econômico de longo prazo, estimulando o investimento privado; b) a abertura comercial (e a valorização cambial) impõe disciplina competitiva aos competidores domésticos, forçando-os a realizar ganhos substanciais de produtividade; c) as privatizações e o investimento estrangeiro removeriam gargalos de oferta na indústria e na infraestrutura, reduzindo custos e melhorando a eficiência e d) a liberalização cambial associada à previsibilidade quanto à taxa real de câmbio atrairia poupança externa em escala suficiente para complementar o esforço de investimento doméstico e financiar o déficit em conta-corrente.

${ }^{276}$ Palavra inglesa com diversos usos nos mercados financeiros, cuja definição básica é diferença de preços ou taxas. GAROFALO FILHO, Emílio. Dicionário de comércio exterior e câmbio. São Paulo: Saraiva, 2004.
} 
esse novo processo de endividamento expôs a economia brasileira à fragilidade e à iminência de um choque externo;

(v) a perigosa combinação de juros-câmbio desestimulou os projetos voltados para as exportações, promoveu um encolhimento das cadeias produtivas e aumentou a participação estrangeira no estoque de capital doméstico, ou seja, essa sistemática redistribuiu renda e riqueza de forma desfavorável aos agentes que comandam o investimento e o gasto e inibiu a acumulação produtiva e a produção para a importação;

(vi) a retração do investimento público e as privatizações impostas pelo regime neoliberal fizeram declinar o gasto com infraestrutura, o que provocou o aparecimento de problemas de sucateamento de áreas estratégicas, tais como energia e transporte;

(vii) a carga tributária aumentou drasticamente (de 22\% do PIB em 1994 pulou para um nível superior a $30 \%$ do PIB em $1998^{277}$ ) para que fosse possível sustentar um modelo de baixo crescimento e desemprego elevado;

(viii) o sistema bancário, devido ao nível de inadimplência acima da média histórica, enfrentou sérias dificuldades financeiras, gerando intervenções de alto custo por parte do Banco Central (PROER ${ }^{278}$ ) e abrindo caminho para uma expressiva desnacionalização do setor (de $9 \%$ dos ativos bancários totais, chegou a $35 \%$ em mãos de instituições estrangeiras em 1998).

Em linhas muito gerais e com base nas lições de BELLUZZO e ALMEIDA, podese dizer que foram esses os aspectos característicos do Plano Real, especialmente entre 1994 e 1998 que levaram o Brasil a assinar em 1999 um acordo com o Fundo Monetário Internacional que lhe deu "sobrevida" e levou à liberação do câmbio em 1999 e ao

\footnotetext{
${ }^{277}$ Estudo divulgado pelo IBPT - INSTITUTO BRASILEIRO DO PLANEJAMENTO TRIBUTÁRIO (Disponível em: <www.ibpt.com.br>), em 01/09/2009, destaca que a carga tributária atingiu 36,4\% (trinta e seis vírgula quatro por cento) do Produto Interno Bruto (PIB) no primeiro semestre de 2009, sem que isso refletisse na melhora dos serviços públicos oferecidos pelo Estado.

${ }^{278}$ Programa de Estímulo à Reestruturação e ao Fortalecimento do Sistema Financeiro Nacional (Proer) implantado por meio da Medida Provisória 1.179 e da Resolução 2.208, ambas de 03.11.1995.
} 
exponencial aumento da dívida pública interna Brasileira, a qual vem multiplicando-se desordenadamente desde então ${ }^{279}$.

Do exposto, verifica-se que o desenvolvimento somente poderá ser alcançado na medida em que os governos passem a adotar medidas que beneficiem o país e não determinados grupos de interesses. Devem adotar uma estratégia que beneficie a exportação, com uma política cambial que torne o mercado brasileiro mais competitivo no que tange ao mercado internacional, fomentar novas competências, explorar o desenvolvimento de novas áreas e melhorar o perfil do endividamento do Estado no que tange à relação da dívida pública versus produto interno bruto, propiciando a geração de empregos e renda.

Como se vê, há muito mais a fazer no que tange ao desenvolvimento da economia brasileira, do que meramente cumprir metas inflacionárias por meio da manipulação da taxa de juros, como vem ocorrendo desde 1994.

A tarefa do Estado brasileiro é, portanto, a superação do subdesenvolvimento, da sua condição periférica. E, para isto, é necessário reestruturar e fortalecer o Estado, sob uma perspectiva democrática e emancipatória, e não desmontar o aparato estatal, como vem ocorrendo no Brasil desde $1994 .^{280}$

Dado o contexto sociopolítico brasileiro do século XX, a seguir será feita a análise do sistema financeiro nacional e de que forma evoluiu no período.

\subsection{O Sistema Financeiro Nacional}

A análise do sistema financeiro de um país pode demonstrar de que forma ele enfrentou as crises e transformações sistêmicas através do tempo. Essa análise representa um importante aspecto, portanto, do estudo da relação entre o Estado e o mercado.

\footnotetext{
${ }^{279} \mathrm{~A}$ alteração do câmbio resultou em expressiva transferência de renda e riqueza em favor dos produtores de tradeables. Na mesma medida, resultou em perda para o que antes foi definido como "importadores" e devedores líquidos em moeda estrangeira, particularmente os que não tiveram condições de compensar por majoração dos preços internos (inflação) a perda inicial. O outro "perdedor", seguindo a regra da execução do Plano Real, foi o setor público, principalmente devido ao encarecimento da dívida pública indexada ao dólar e ao aumento dos pagamentos de juros, os quais em parte foram compensados por elevação da carga tributária, mediante, sobretudo, a majoração dos tributos cumulativos de pior qualidade, e pelo rebaixamento de salários, devido à inflação. BELLUZZO, Luiz Gonzaga de Mello; ALMEIDA, Júlio Gomes de. p. 394.

${ }^{280}$ BERCOVICI, Gilberto. O ainda indispensável direito econômico, cit., p. 507.
} 
Além disso, verifica-se sua especial relevância para o escopo deste trabalho tendo em vista que os bancos centrais representam o pilar de sustentação dos sistemas financeiros dos países da era capitalista e, no caso do Brasil, isso não é diferente.

Nesse sentido, a seguir serão destacadas as principais instituições que contribuíram para a formação do Sistema Financeiro Nacional ao longo da formação do Estado Brasileiro.

\subsubsection{O Banco do Brasil}

O Banco do Brasil ocupou, por um longo período (1808 281 a 1964), posição central no sistema financeiro do país. Antes Banco da República do Brasil, em 1905 ganhou a razão social atual e tornou-se "banco do governo", quando uma crise bancária quase provocou a quebra de seu antecessor, o que acabou não acontecendo devido ao socorro do Tesouro Federal (que adquiriu um terço de suas ações). O "novo" banco ficou sob controle direto da União e era o Presidente da República o responsável pela nomeação do seu presidente e diretores.

Em 1923, o Tesouro comprou ações adicionais do Banco do Brasil, tornando-se acionista majoritário. Em 1942, os estatutos do Banco do Brasil sofreram reformulações para se adequarem à nova Lei das Sociedades por Ações (Decreto-Lei 2627 de 26.09.1940), momento em que foi estatuída a sua função de autoridade monetária garantidor de liquidez ao sistema bancário e peça importante para a execução da política monetária - sem, contudo, deixar de ser banco comercial. Conforme destaca Gilda Portugal Gouvêa sobre este acontecimento ${ }^{282}$ :

(...)ficou consagrada a dualidade dos papéis, que durante os 45 anos seguintes provocou tanta controvérsia: [o Banco do Brasil] passou a atuar como autoridade monetária e banco comercial. No primeiro papel, estava encarregado das emissões, da arrecadação das rendas federais, os pagamentos autorizados pelo governo, das antecipações ao governo, além de atuar como agente federal nas operações de câmbio. No segundo papel, captava recursos e financiava as atividades produtivas.

\footnotetext{
${ }^{281}$ O primeiro Banco do Brasil foi criado no período em que a família real portuguesa aportou no país. Tinha como funções iniciais ser depositário do governo. Tratava-se de um banco que integrava o patrimônio da Coroa.

${ }^{282}$ GOUVÊA, Gilda Portugal. op. cit., p. 93.
} 
Até a década de 1940 tudo se concentrava no Banco do Brasil. Esse banco: exercia o controle da expansão creditícia, mediante a Caixa de Mobilização Bancária (Camob) ${ }^{283}$; mantinha o controle quantitativo e crédito por meio da carteira de redesconto e, na condição de intermediador bancário de empresa de capital misto, atuava não apenas como banco de depósitos e emprestador de dinheiro, como também banco controlador dessas funções.

Ao exercer as funções de controle, assumia os encargos e privilégios da administração pública, e nessa perspectiva, ao se relacionar com o sistema bancário, submetia-se aos parâmetros que a legislação impunha ao poder público. Por ocupar essa função paradoxal de gestor do sistema e integrante deste na qualidade de banco privado, o Banco do Brasil transformou-se num vigoroso multiplicador de inflação de crédito ${ }^{284}$, o que gerou uma política de crédito desorientada e inflacionada, tornando-se fonte de empobrecimento social, quando deveria produzir justamente o efeito contrário.

Conforme destaca PAUL HUGON ao analisar a organização bancária antes da reforma de 1964:

O setor bancário privado é, na realidade, um setor relativamente semipúblico, encontrando-se dominado, em parte, pelo Banco do Brasil. De fato é ao mesmo tempo banco oficial - e a esse título executa a política financeira e monetária do Governo - e banco comum, operando nesse caso como os outros bancos comerciais, em concorrência com eles, tendo o direito de controlar suas atividades ${ }^{285}$.

A posição vantajosa ocupada pelo Banco do Brasil no sistema gerou resistência para a criação de um Banco Central. A política monetária nesse período de hegemonia do Banco do Brasil reduzia-se a cobrir os déficits do Tesouro por meio da expansão privada

\footnotetext{
${ }^{283}$ DE CHIARA, José Tadeu. Disciplina jurídica das instituições financeiras, cit., p. 292, ressalta que a CAMOB foi concebida com o objetivo de auxiliar o país a recuperar-se da situação de crise enfrentada em razão da Grande Depressão de 1929, mas que não havia naquele momento o intuito de disciplinar o mercado financeiro; ao contrário, tratou-se mais de uma solução imediatista para a situação de insolvabilidade de muitas instituições bancárias brasileiras, desorganizadas financeiramente: Na verdade, o mecanismo da Caixa de Mobilização bancária, todo ele gerido pelo Banco do Brasil S.A procurava estabelecer taxas de juros abaixo de $1 \%$ ao mês prazos de até cinco anos para suprir recursos aos bancos necessitados. Daí decorreria que todo o sacrifício da crise monetária recairia sobre os ombros do Estado e do povo de forma geral pois, em época que a moeda perdia seu poder aquisitivo sem que houvesse qualquer fórmula adaptada para corrigi-la, dados os prazos longos e as taxas de juros baixas, fácil é de concluir-se que esse sistema geraria uma especulação monetária prejudicial, naturalmente.

${ }^{284}$ DE CHIARA, José Tadeu. Disciplina jurídica das instituições financeiras, cit., p. 293.

${ }^{285}$ HUGON, Paul. A moeda: introdução à análise e às políticas monetárias e à moeda no Brasil. Tradução de Diva Benevides Pinho. 21. ed. São Paulo: Pioneira, 1973. p. 186.
} 
da moeda. Situação que, mesmo com a criação da SUMOC e, em seguida, do Banco Central do Brasil, prolongou-se até meados da década de 1980.

A relação entre o Banco do Brasil e o Tesouro dava-se da seguinte forma: nas ocasiões em que o Tesouro estava em déficit, ou seja, quando o total de cheques emitidos por conta do Tesouro Nacional ultrapassava seus depósitos perante o Banco do Brasil, este, automaticamente, concedia-lhe um empréstimo.

Entre 1923 e 1945, fase em que o Banco do Brasil era a autoridade máxima em termos de política monetária, não havia controle do seu exercício, bem como da administração das contas públicas. Posteriormente, a instituição responsável por fiscalizar essas atividades passou a ser a recém-criada Superintendência da Moeda e do Crédito (SUMOC) - composta, em sua maioria, por funcionários do Banco do Brasil, o que, no fim, não mudou esse cenário.

No entanto, a promiscuidade (não existe palavra mais adequada neste caso) da política monetária infelizmente não cessou com o advento da Lei 4595/64 que instituiu o Banco Central do Brasil. Em 1965, por meio de carta reversal enviada pelo presidente do Banco do Brasil ao Banco Central foi criada, sem qualquer embasamento legal, a chamada Conta--Movimento com o objetivo provisório de registrar fluxos transitórios entre essas instituições. O saldo dos valores deveria ser apurado semanalmente com a cobrança de juros de $1 \%$ ao ano sobre o débito líquido da instituição que estivesse em posição devedora $^{286}$.

Tendo em vista que foi criada por meio de um mecanismo quase informal e não havia norma que regulasse essa relação, a conta-movimento tornou-se rapidamente uma fonte de suprimento de recursos automática para o Banco do Brasil.

Mais do que a sistemática, mas principalmente o uso que se fez da conta movimento, feria claramente a própria lei 4595 , que no seu artigo 19 , parágrafo primeiro, atribuía ao Conselho Monetário Nacional (e não ao Banco do Brasil) a tarefa de alocar qualquer tipo de recursos definidos pela política econômica do Governo. Esta conta que foi crescendo ao longo do tempo, além de tornar impossível para o Banco Central o cumprimento de sua tarefa de controle de todas as contas vinculadas à política monetária do país (como seu executor institucional), retirava o poder de autoridade monetária do Conselho Monetário Nacional. Durante duas décadas $(1965$ - 1985) praticamente todo o relacionamento financeiro do Banco Central e do Banco do Brasil era feito através desta conta, sendo que na realidade o Banco do Brasil podia decidir o que

\footnotetext{
${ }^{286}$ As disposições deste trabalho a respeito dos mecanismos da conta-movimento foram extraídas das seguintes obras: GOUVÊA, Gilda Portugal. op. cit., p. 150 e ss. e JALORETTO, Cláudio. op. cit., p. 55-57.
} 
debitar na Conta Movimento, já que não houve qualquer norma que limitasse o seu uso ${ }^{287}$

Os únicos registros das transações da conta-movimento advinham do Orçamento Monetário, um mecanismo contábil não sujeito à apreciação do Congresso Nacional e do Tribunal de Contas. Esse mecanismo levou ao retorno das práticas usualmente empregadas antes da edição da Lei 4595, em que não havia separação entre as políticas fiscal e monetária. Uma verdadeira anomalia que se perpetuou, mesmo depois da reforma bancária.

Deve-se ponderar, no entanto, que esta situação prolongou-se por tanto tempo não havia interesse institucional em se encerrar esse mecanismo de obtenção de crédito barato e sem precisar prestar contas sobre o que se estava fazendo com os valores tomados. A alocação dos investimentos estava sujeita ao jogo de interesses dos governantes. Volta-se, portanto, ao clientelismo tão típico na história brasileira.

De fato, no Brasil, de controlador da política monetária e creditícia, o Banco Central tornou-se concedente de créditos para o Tesouro financiando os governos durante décadas. O mecanismo do open market, por exemplo, funcionou não como instrumento de controle do crédito, mas como forma de financiar déficits orçamentários. Houve, desde a sua constituição em 1964, a distorção das atividades que deveria desempenhar. Certamente isso poderia ter sido limitado de alguma forma a fim de que não se atingisse o patamar de descontrole das finanças públicas a que se chegou em $1980^{288}$.

Em 1986, no contexto das reformas que acompanharam o Plano Cruzado ${ }^{289}$, ocorreram alterações fundamentais no relacionamento do Banco do Brasil com o Banco Central e o Tesouro Nacional. Principalmente, vale mencionar que nessa reforma se deu o congelamento do saldo e posterior extinção da chamada "conta-movimento", 290 encerrando o papel de autoridade monetária do Banco do Brasil.

\footnotetext{
${ }^{287}$ GOUVÊA, Gilda Portugal. op. cit., p. 56.

${ }^{288} \mathrm{Em}$ termos de mudanças institucionais, ao final da década de 70 já se discutia nos meios acadêmicos e políticos, a necessidade de mudanças nas relações entre o Tesouro Nacional, o Banco do Brasil e o Banco Central, que pudessem trazer transparência as contas fiscais, de forma a que se dimensionasse adequadamente o déficit público e que pudessem dotar o Banco Central de condições adequadas à gestão da política monetária. JALORETTO, Cláudio. op. cit., p. 61.

${ }^{289}$ O Plano Cruzado foi um conjunto de medidas econômicas para conter a inflação e estabilizar a moeda, lançado pelo governo brasileiro em 28 de fevereiro de 1986, com base no decreto-lei 2.283, de 27.02.1986, com José Sarney como presidente da República. As principais medidas foram a reforma monetária, com o Cruzeiro substituído pelo Cruzado, o congelamento de preços de bens e serviços e também dos salários, além de ser proibida a estipulação de reajuste monetário nos contratos de prazo inferiores a um ano.

${ }^{290}$ Mais detalhes sobre a questão da conta-movimento e a reforma de 1986 serão analisadas no tópico específico sobre o Banco Central.
} 
Dois anos depois, em 1988, a promulgação da Constituição Federal representou outro marco na história dessa instituição, com a definitiva exclusão da competência do Banco do Brasil para exercer a função de caixa do Tesouro. A partir de então, embora permanecesse como um instrumento de política pública na qualidade de agente governamental de crédito, passou a atuar em pé de igualdade no plano da concorrência com os demais bancos.

Por fim, em 1990, com o Plano Collor, ocorreu a extinção da Carteira de Comércio Exterior do Banco do Brasil (Cacex) - carteira administrada pelo Banco do Brasil e direcionada ao financiamento do comércio exterior brasileiro - e a transferência de suas funções para o então Ministério da Economia.

O congresso, desde a primeira proposta, sempre resistiu à criação de um Banco Central. Entretanto, o Congresso era apenas o porta-voz de uma pressão vinda de duas fontes. A primeira delas tinha origem no Banco do Brasil, que sempre viu, desde o tempo de criação da Sumoc, com enormes resistências, o aparecimento de qualquer outro órgão que pudesse diminuir ou controlar seu poder, até então bastante grande ${ }^{291}$.

Do exposto, verifica-se que o Banco do Brasil tem uma posição de destaque na história de formação do Sistema Financeiro Nacional. Foi a primeira instituição oficial organizada a exercer formalmente algumas das funções de banco central e foi também a instituição que, em larga medida, por meio de seu corpo burocrático, ofereceu resistência à criação de um verdadeiro banco central.

\subsubsection{A SUMOC}

A Superintendência da Moeda do Crédito (SUMOC) foi instituída pelo Decreto-Lei 7.923, em 1945, com duas funções principais: controlar o mercado monetário e preparar o terreno para a instituição de um banco central dotado de todas as atribuições e competências necessárias ao desempenho de uma política monetária adequada ${ }^{292}$.

Nos termos do art. 3. ${ }^{\circ}$ do Decreto-Lei n. ${ }^{\circ}$ 7.293, de 2 de fevereiro de 1945, competia à Superintendência da Moeda e do Crédito: (i) requerer emissão de papel-moeda

\footnotetext{
${ }^{291}$ GOUVÊA, Gilda Portugal. op. cit., p. 134.

${ }^{292}$ Sobre as funções clássicas de um Banco Central, ver o capítulo II e, como fonte adicional, VERÇOSA, Haroldo Malheiros Duclerc. Os regimes jurídicos e políticos dos Bancos Centrais: Sistema Financeiro Nacional e o Banco Central do Brasil, cit., p. 125-168.
} 
ao Tesouro Nacional; (ii) receber, com exclusividade, depósitos de bancos; (iii) delimitar, quando julgar necessário, as taxas de juros a abonar às novas contas, pelos bancos, casas bancárias e caixas econômicas; (iv) fixar, mensalmente, as taxas de redesconto e juros dos empréstimos a bancos, podendo vigorar taxas e juros diferentes, tendo em vista as regiões e peculiaridades das transações; (v) autorizar a compra e venda de ouro ou de cambiais; Autorizar empréstimos a bancos por prazo não superior a cento e vinte (120) dias, garantidos por títulos do Governo Federal até o limite de noventa por cento (90\%) do valor da Bolsa; (vi) orientar a fiscalização dos bancos; (vii) orientar a política de câmbio e operações bancárias em geral; (viii) promover a compra e venda de títulos do Governo Federal em Bolsa e (ix) autorizar o redesconto de títulos e empréstimos a bancos nos termos da legalização que vigorar.

Os membros da SUMOC eram demissíveis ad nutum pelo Presidente da República. O Conselho de direção da SUMOC era presidido pelo Ministro das Finanças e composto pelo Presidente do Banco do Brasil, pelo Diretor Executivo da SUMOC, e pelos diretores das Carteiras do Banco do Brasil.

Conforme destaca Paul Hugon, na obra "A Moeda"293, a SUMOC, embora tenha sido instituída para proporcionar condições favoráveis à instituição de um Banco Central, acabou por vincular-se, por meio da composição de seu Conselho, ao poder executivo e ao Banco do Brasil.

De Chiara, esclarece que, por ser um órgão da administração pública com dependência direta do Governo Federal, a SUMOC estava destinada a atender os interesses de seus governantes, cujas gestões nem sempre se pautavam pelo desenvolvimento de uma política monetária e creditícia adequada e em conformidade com os interesses da nação:

Dessa forma, era a SUMOC apenas um ente destinado a atender às necessidades do Governo Federal, de acordo com os respectivos líderes, cujas gestões financeiras não se pautavam, na maioria das vezes, numa política monetária e creditícia bem orientada. Daí conclui-se que longe esteve a SUMOC de desempenhar o papel de órgão técnico a serviço do interesse social, como deveria ser segundo o caráter instrumental das normas de Direito Econômico, as quais por isso devem servir a dotar o Estado de meio de realizar os ideais sociais de bem-estar e desenvolvimento, próprios de nosso século ${ }^{294}$.

\footnotetext{
${ }^{293}$ HUGON, Paul. A moeda: introdução à análise e às políticas monetárias e à moeda no Brasil, cit., p. 183 e ss.

${ }^{294}$ DE CHIARA, José Tadeu. Disciplina jurídica das instituições financeiras, cit., p. 294.
} 
Assim, a coordenação entre os organismos e as autoridades encarregadas da política monetária e financeira que seria de sua exclusiva competência acabava por determinar-se junto ao corpo diretivo do Banco do Brasil. Faltava à SUMOC autonomia para a execução de suas funções e a independência para as decisões de seu Conselho, mesmo porque este era integrado por pessoas vinculadas a outras instituições com outros interesses.

No entanto, sua criação foi essencial, especialmente por ter possibilitado a formação de um quadro de especialistas preparados para a desempenhar funções especializadas no Banco Central. Extinguiu-se no momento da criação deste, em 1964.

\subsubsection{O BNDES}

A Lei n. ${ }^{\circ} 1.628$, de 20 de junho de $1952^{295}$ instituiu o Banco do Desenvolvimento Econômico (BNDE), instituição especializada em financiamento de longo prazo à indústria, que surgiu para coordenar o projeto desenvolvimentista nacional, pois, conforme destacou Octavio Gouvêa de Bulhões ${ }^{296}$, não havia, até aquele momento da história do Brasil, uma instituição organizada capaz de acompanhar e planejar investimentos.

O BNDE foi, portanto, criado com propósitos bem definidos, inclusive legalmente estabelecidos $^{297}$, reforçados no período em que ocupou o cargo de Presidente da República,

\footnotetext{
${ }^{295}$ Parte das informações deste tópico foi obtida por meio do site do BNDES. Disponível em: <www.bndes.gov.br>. Acesso em: 15 nov. 2009.

${ }^{296}$ BULHÕES, Octavio Gouvêa. Depoimento. Brasília: Divisão de Impressão e Publicações do Departamento de Recursos Materiais do Banco Central do Brasil, 1990. p. 82. Cabe destacar, mais especificamente, que o BNDE surgiu para gerir os recursos destinados aos projetos recomendados pela Comissão Mista BrasilEstados Unidos de Desenvolvimento Econômico, comissão criada no ano anterior, com o objetivo de fomentar a instalação de novas indústrias e corrigir falhas nos setores de energia e transportes.

${ }^{297}$ Merecem destaque as seguintes normas editadas na época da constituição do BNDE:

- Lei 1.474 de 26.11.1951, direcionou parte do recolhimento do imposto de renda a um fundo especial que compreenderia a fonte inicial de recursos utilizada pelo BNDE, com sua criação, no ano seguinte, conforme as prioridades estabelecidas no art. $3 .^{\circ} \S 1^{\circ}$ :

Art. (...) $\S 1^{\circ} \mathrm{O}$ montante do adicional a que se refere o artigo constituirá fundo especial, com personalidade contábil, e será aplicado na execução do programa de reaparelhamento de portos e ferrovias, aumento da capacidade de armazenamento, frigoríficos e matadouros, elevação do potencial de energia elétrica e desenvolvimento de indústrias básicas e de agricultura. (grifou-se)

- Lei 1.628, de 20.06.1952, que criou o Banco Nacional do Desenvolvimento Econômico, dispunha em seu artigo 10 de que forma o BNDE receberia os recursos direcionados ao financiamento e a quem poderia direcionar esses empréstimos:

Art. 10. O Banco exercerá todas as atividades bancárias, na forma da legislação em vigor, dentro de limites e condições que serão fixados no regimento interno, e mais os seguintes:

I - só poderá receber depósitos:

a) de entidades governamentais ou autárquicas;

b) de sociedades de economia mista em que preponderem as ações do Poder Público;
} 
Juscelino Kubitschek $(1956 \text { - 1961 })^{298}$, eleito com a promessa de estruturar o Plano de Desenvolvimento Econômico para o Brasil e cuja meta era que isso acontecesse rapidamente, durante o seu mandato, superando todo um passado de atrasos - "Cinquenta anos em cinco". Para tanto, esse Presidente criou o aparato institucional necessário a fim de possibilitar uma política de crédito direcionada a atingir tais objetivos.

Alberto Venâncio, a respeito da formação e importância do BNDE para o crescimento do país, destaca:

O mecanismo operacional do Banco resultou da vinculação de recursos específicos sob a forma de empréstimos, que se destinariam à aplicação nos setores prioritários da economia nacional, baseados no programa de reaparelhamento econômico criado pela Comissão Mista Brasil-Estados Unidos. (...) Por força da posição singular que a instituição adquiriu na gestão dos recursos que lhe foram atribuídos, coube-lhe, também, a administração de vários fundos vinculados, criados a partir de sua fundação, e por ela geridos até que surgissem instituições específicas em cada setor. Tal foi o caso do Fundo Federal de Eletrificação, Fundo da Marinha Mercante, Fundo portuário nacional etc. (...) De qualquer

c) de bancos, quando e nas condições que forem estabelecidas pela Superintendência da Moeda e do Crédito;

d) de sociedades de seguro e capitalização, para os fins do art. $7^{\circ}$ desta Lei;

e) judiciais;

f) que resultarem de operações realizadas pelo Banco ou que a elas estejam diretamente vinculadas;

II - só poderá efetuar empréstimos ou financiamentos com os objetivos de reaparelhamento e fomento estabelecidos nas Leis n. ${ }^{\circ} \mathrm{S} 1.474$ (art. $3^{\circ}$ ) e 1.518. (grifou-se)

- Lei 2.973, de 26.11.1956 estabeleceu a ordem de prioridades do Plano de Desenvolvimento Econômico no que tange aos setores da economia (artigo 25) e no que tange as regiões brasileiras, art.34:

Art. 25. O Orçamento de Investimento, de que trata o artigo anterior, fixará a quota destinada a cada um dos setores de atividades econômicas mencionadas nas Leis n. ${ }^{\circ}$ s 1.474 , de 26 de novembro de 1951 (art. $3^{\circ}$ ), 1.518, de 24 de dezembro de 1951, e 1.628, de 20 de junho de 1952, e nesta Lei, com observância da seguinte ordem de prioridade:

I - reaparelhamento e ampliação do sistema ferroviário;

II - reaparelhamento e ampliação de portos e de sistemas de navegação;

III - construção e ampliação de sistemas de energia elétrica;

IV - instalação e ampliação de indústrias básicas;

V - construção e ampliação de armazéns, silos, matadouros e frigoríficos;

VI -desenvolvimento da agricultura, compreendendo eletrificação rural, inclusive mediante aproveitamento acessório de pequenas quedas d'água;

VII - outros setores.

$\S 1^{\circ}$ A quota destinada a um setor poderá ser transferida para outro, se não houver, em estudo e com viabilidade de deferimento, qualquer projeto de financiamento nele enquadrado.(...)

Art. 34. Do total dos recursos provenientes do empréstimo compulsório, de que tratam as Leis $1.474 \mathrm{e}$ 1.628, e cuja vigência é prorrogada pela presente Lei, o Banco Nacional do Desenvolvimento Econômico destinará para aplicação, em caráter de prioridade, $25 \%$ (vinte e cinco por cento) em empreendimentos definidos nas Leis 1.474, de 26 de novembro de 1951, 1.518, de 24 de dezembro de 1951, e 1.628, de 20 de junho de 1952, localizados ou que se venham a localizar nas regiões Centro-Oeste, Norte, Nordeste, inclusive Sergipe, Bahia e Espírito Santo, e destinados a elevar o nível de renda per capita, ou melhorar as condições econômicas das regiões acima mencionadas. (grifou-se)

${ }^{298}$ Conforme mencionado, na área econômica, o lema do governo foi "Cinquenta anos de progresso em cinco anos de governo". Para cumprir com esse objetivo, o governo federal elaborou o Plano de Metas, que previa um acelerado crescimento econômico a partir da expansão do setor industrial, com investimentos na produção de aço, alumínio, borracha, construção naval e maquinaria pesada. 
maneira tratava-se de um mecanismo hábil de captação de recursos adicionais que, pela sua vinculação, tornavam-se imunes à utilização nos setores normais do Poder Público e puderam assim impulsionar os grandes problemas de investimentos do Governo Federal ${ }^{299}$.

Embora tenha sido essencial para alçar o Brasil ao patamar dos países industrializados, capaz de atuar no mercado internacional na qualidade de exportador não somente de matérias primas, mas também de produtos manufaturados devido à forte indústria de base que aqui se formou, o projeto desenvolvimentista também trouxe alguns desequilíbrios à economia brasileira, tais como o expressivo aumento da inflação e do endividamento externo.

Esse período de abertura comercial testemunhou a chegada das multinacionais ao Brasil, criticadas por investirem pouco com capital próprio e enviarem à matriz boa parte dos lucros obtidos aqui ${ }^{300}$. Eram as nascentes estruturas que se acomodavam nos países subdesenvolvidos para, poucos anos depois, passarem à posição de comando no que tange às transformações dos arranjos institucionais globais.

Assim, embora tenha tido o viés nacionalista de desenvolver o Brasil rapidamente, o projeto desenvolvimentista pautou-se pela consolidação de um regime extremamente dependente do capital estrangeiro, instrumentalizado pelo BNDE. Com efeito, a presença desse capital estrangeiro na forma de investimentos diretos e, especialmente, na forma de empréstimos, foi um dos fatores determinantes da crise da dívida externa de 1980.

Na primeira década de sua existência, o BNDE, embora estivesse apto a mobilizar capital tanto para investimentos públicos quanto para investimentos privados, especializouse no financiamento de grandes obras públicas de infraestrutura, o que, por outro lado,

\footnotetext{
${ }^{299}$ VENÂNCIO FILHO, Alberto. op. cit., p. 372.

${ }^{300}$ As transformações estruturais que ocorreram na segunda metade dos anos 1950 resultaram na consolidação da oligopolização da economia brasileira, quando os principais ramos industriais passaram a ser constituídos por um reduzido número de grandes empresas, reproduzindo o processo que se iniciara ainda no final do século XIX com as economias capitalistas desenvolvidas. A participação hegemônica do capital internacional na produção manufatureira também foi possível devido à própria mudança de estratégia de investimento das grandes corporações estrangeiras, que em meados da década de 1950 estavam começando seus movimentos de transnacionalização. O acirramento da concorrência entre os grandes oligopólios internacionais americanos, europeus e japoneses estendeu essa disputa até os países subdesenvolvidos. (...)As empresas multinacionais passaram a dominar amplamente a produção industrial brasileira especialmente os setores mais dinâmicos da indústria de transformação. LACERDA, Antônio Correa de; BOCCHI, João Ildebrando; REGO, José Marcio; BORGES, Maria Angélica; MARQUES, Rosa Maria. op. cit., p. 102.
} 
gerou carência de financiamentos do setor privado, ansioso por acompanhar a euforia desenvolvimentista do período ${ }^{301}$.

Em 1971, com a edição da Lei 5.662, o BNDE, de autarquia, converteu-se em empresa pública ${ }^{302}$ o que possibilitou atuar com maior liberdade no que tange ao estabelecimento de critérios para o direcionamento das operações de captação e aplicação de recursos com menor interferência política. Desde então, os investimentos passaram a ser mais direcionados ao setor privado. Durante a década de 1970 o BNDE privilegiou os setores de bens de capital e insumos básicos e também os segmentos ainda incipientes, como a informática e a microeletrônica.

No início da década de 1980, o BNDE integrou a sua política de desenvolvimento às preocupações sociais. Tal alteração se refletiu no nome do Banco que, em 1982, passou a se chamar Banco Nacional de Desenvolvimento Econômico e Social (BNDES) ${ }^{303}$. Ironicamente, nesse mesmo período começaram a ruir as bases que firmavam os paradigmas do Estado empresário e os objetivos sociais incorporados ao nome do BNDES mantiveram-se somente no nome; não chegaram a afetar positivamente a realidade social brasileira.

Nos anos de 1990, coordenado com as novas diretrizes do governo, já ajustadas as diretrizes fixadas pelo Consenso de Washington ${ }^{304}$, o BNDES direcionou os recursos de que dispunha para viabilizar o processo de privatização das estatais brasileiras.

\footnotetext{
${ }^{301}$ Até fins da década de 50, a estrutura financeira nacional incluía, basicamente, bancos comerciais, caixas econômicas, seguradoras, financeiras, BNDE e BNCC [Banco Nacional de Crédito Cooperativo]. As caixas econômicas eram basicamente instituições voltadas ao financiamento da habitação além de promoverem empréstimos em consignação, principalmente a funcionários públicos, e executarem pequenos empréstimos de caráter social, mediante a penhora de bens individuais. Dessa forma competia aos bancos comerciais grande responsabilidade pelo financiamento das atividades produtivas no Brasil. No entanto, o sistema bancário resumia-se essencialmente a crédito de curto prazo, pois os bancos brasileiros raramente operavam com empréstimos e financiamento de longo prazo. ANDREZO, Andréa Fernandes; LIMA, Iran Siqueira. Mercado financeiro: aspectos históricos e conceituais. São Paulo: Thomsom Learning, 2002. p. 29.

${ }^{302}$ Aliás, a forma jurídica de empresa pública certamente é muito mais adequada aos objetivos do BNDES se comparada à autarquia, dado que empresa pública é a empresa dotada e capital estatal que atua na economia como "instrumento de ação do Estado", senão veja-se a definição utilizada por MELLO, Celso Antônio Bandeira de. Curso de direito administrativo. 16. ed. São Paulo: Malheiros, 2002. p. 172: "Deve-se entender que empresa pública federal é a pessoa jurídica criada por força legal como instrumento de ação do Estado, dotada de personalidade de Direito Privado, mas submetida a certas regras especiais decorrentes de ser coadjuvante da ação governamental, constituída sob quaisquer formas admitidas em direito e cujo capital seja formado unicamente por recursos de pessoas de Direito Público interno ou de pessoas de suas administrações indiretas, com predominância acionária residente na esfera federal”.

${ }^{303}$ Decreto-lei 1.940 de 25 de maio de 1982 alterou a razão social do BNDE para BNDES, vinculando-o administrativamente à Secretaria de Planejamento da Presidência da República, instituiu a contribuição social, criou o Fundo de Investimento Social (FINSOCIAL) e deu outras providências.

${ }^{304}$ Tal estratégia de desenvolvimento, em geral associada às recomendações do Consenso de Washington e adotada pelos governos da América Latina, estava apoiada, inicialmente, em quatro supostos: a estabilidade
} 
Além de ter capitaneado a organização desse processo, o BNDES foi designado o gestor do Fundo Nacional de Desestatização (FND), efetuou a licitação e a contratação dos prestadores de serviços que atuariam no Programa Nacional de Desestatização (PND), bem como das empresas encarregadas de divulgarem as informações relacionadas a tal programa.

O BNDES supervisionou, acompanhou e coordenou os trabalhos relativos ao PND e foi o responsável direto por orientar o Conselho Nacional de Desestatização (CND) sobre as condições gerais de venda das estatais ${ }^{305}$.

É de se questionar até que ponto "colaborar" com as privatizações das estatais e, mais ainda, conceder crédito a empresas estrangeiras para que estas possam adquirir as estatais apresenta-se como uma ação voltada ao desenvolvimento e ao progresso nacional, objetivos para os quais essa instituição foi desenvolvida.

Como resultado final desse processo, verificou-se que, desde a criação do PND até janeiro de 2002, 68 empresas haviam sido privatizadas rendendo ao Governo Federal um total de U\$28,58 bilhões. Vale consignar que, dentre as empresas estatais sujeitas ao processo de privatização, boa parte era considerada "estratégica" para o desenvolvimento nacional, tais como empresas do setor siderúrgico, petroquímico e de telecomunicações.

O foco deste trabalho não é, de todo modo, analisar a adequação da política de crédito executada pelo BNDES, mas, sim, compreender de que forma o sistema financeiro nacional se construiu e que a atuação do Banco Central está pautada e ajustada a certos comportamentos, devido não apenas ao contexto histórico e social em que se insere, mas também à orientação política que o conduz. Assim, a condução da política de crédito do BNDES serve mais como ponto de reflexão, que deverá corroborar a compreensão da análise a ser feita mais adiante.

\footnotetext{
de preços cria condições para o cálculo econômico de longo prazo, estimulando o investimento privado; a maior abertura comercial impõe disciplina competitiva aos produtores domésticos, forçando-os a realizar ganhos substanciais de produtividade; as privatizações e o investimento estrangeiro removeriam gargalos de oferta na indústria e na infra-estrutura, reduzindo custos e melhorando a eficiência; a abertura da conta de capital, associada à previsibilidade quanto à evolução da taxa real de câmbio, atrairia poupança externa em escala suficiente para complementar o esforço de investimento doméstico e para financiar o déficit em conta corrente. Nesta perspectiva, no que respeita à política macroeconômica, o Estado deveria limitar sua ação à busca da estabilidade de preços e à manutenção do equilíbrio intertemporal das finanças públicas. BELLUZZO, Luiz Gonzaga; CARNEIRO, Ricardo. Bloqueios ao crescimento. Política Econômica em Foco, n. 3, p. 1, jan./abr. 2004.

${ }^{305}$ LACERDA, Antônio Correa de; BOCCHI, João Ildebrando; REGO, José Marcio; BORGES, Maria Angélica; MARQUES, Rosa Maria. op. cit., p. 216 e ss.
} 


\title{
3.4. A reforma do Sistema Financeiro e a instituição do Banco Central do Brasil
}

As décadas de 1960 e 1970 trouxeram diversas reformas na legislação concernente ao setor financeiro. Pode-se dizer que esses períodos significam para o sistema financeiro nacional o mesmo que significou a década de 1930 para a industrialização do país.

A deficiência de crédito direcionado ao investidor privado, somada à existência de uma política monetária pouco ativa, bem como à falta de regulação das atividades bancárias levou, desde fins da década de 1950, à reforma legislativa do sistema financeiro nacional (na verdade, pode-se dizer que a partir desse momento estabeleceu-se um verdadeiro sistema financeiro), com a regulamentação das Sociedades de Crédito (Portaria do Ministério da Fazenda 309/1959), a regulamentação dos capitais estrangeiros (Lei 4131/1962), a criação do Banco Central do Brasil (Lei 4695/1964) e, na década seguinte, a criação da Comissão de Valores Mobiliários (Lei 6385/1976) e a nova regulamentação das Sociedades Anônimas (Lei 6404/76), apenas para citar algumas das normas mais importantes.

Camargo Vidigal, ao analisar o exercício da política monetária no Brasil antes da edição da Lei 4595, destaca que não havia interesse em regrar e disciplinar o mercado financeiro, tampouco em estabelecer controles adequados para o desenvolvimento das contas públicas, caracterizando-se a relação entre o Banco do Brasil e as demais instituições bancárias como um verdadeiro descontrole:

\begin{abstract}
Se considerarmos que os papéis do próprio Banco do Brasil têm acesso ao redesconto e que dos empréstimos desse banco se alimenta o próprio Tesouro Nacional - além de outras entidades de direito público e de numerosa clientela privada - teremos um esboço de como funcionam realmente as emissões. O quadro não se completa senão com a consideração de que o Congresso Nacional tem tradicionalmente aprovado orçamentos deficitários, sem exame da adequação de tais decisões ao nível existente de atividade econômica; pode acrescentar novas despesas à proposta orçamentária e usa largamente dessa faculdade; abre ainda habitualmente ao Poder Executivo créditos especiais e extraordinários sem indicação das fontes de recursos a utilizar ou a preocupação com a efetiva existência dos recursos. ${ }^{306}$
\end{abstract}

\footnotetext{
${ }^{306}$ VIDIGAL, Geraldo de Camargo. Disciplina dos órgãos de direção monetária. Tese (Livre Docência) Faculdade de Direito, Universidade de São Paulo, São Paulo 1964. p. 39. Nesse mesmo sentido, DE CHIARA, José Tadeu. Disciplina jurídica das instituições financeiras, cit., p. 292. Na verdade, decisões desencontradas e, mesmo, antagônicas, que pretendiam nortear uma política monetária, desnorteavam toda a economia nacional. Inexistiam quaisquer medidas coerentes de zelo pela administração de moeda e crédito, atuando os bancos, ainda, segundo regras arcaicas baseadas em princípios monetários que, poderíamos dizer, voltados para a especulação.
} 
Essa realidade foi transformada na época da ditadura militar, período dos mais profícuos em termos de legislação voltada para a regulação e sistematização do mercado financeiro $^{307}$ e uma explicação plausível para isso seria o fato de que havia muitas pressões da sociedade civil, especialmente advindas do setor comercial e industrial para que não houvesse a reforma bancária e, especialmente, a criação do Banco Central o qual, comparativamente às demais economias capitalistas, foi instituído com considerável atraso.

Faz parte da história do Brasil uma resistência muito grande à criação do Banco Central. Já em 1931, Otto Niemeyer preparou um projeto de lei transformando Banco do Brasil em Banco Central, e Vargas, apesar de ditador, sem Congresso, não teve coragem de baixar um decreto-lei que o pusesse em vigor. Outras tentativas posteriores tampouco obtiveram êxito. (...) A atividade econômica urbana - comércio e indústria habituou-se ao longo dos anos a viver à custa da expansão monetária, e consequentemente, da inflação. Falar em controle de crédito para indivíduos que dependem de sua expansão para o dia-a-dia das operações que realizam é realmente assustador. Por isso, as empresas reunidas em órgãos como a Fiesp ou a Associação Comercial opunham-se à reforma bancária e manifestavam grande animosidade em relação ao controle de crédito, que é uma das funções do banco central ${ }^{308}$.

Além do declarado desinteresse das classes dominantes em estabelecer controles no que tange à concessão de crédito, havia, ainda, a pressão exercida pelos burocratas do poderoso Banco do Brasil que não concordavam com a possibilidade de que a instituição viesse a perder espaço, conforme se mencionou.

Segundo Alberto Venâncio ${ }^{309}$, três pontos essenciais desencadearam a reforma do Sistema Financeiro Nacional e foram o foco de discussão no momento da edição da norma reguladora de tal sistema: (i) como dividir as funções normativas e executivas entre Banco Central e Banco do Brasil; (ii) a quem caberia a responsabilidade pela emissão monetária e a quem caberia a fiscalização dessa emissão; (iii) como seria definida a disciplina dos bancos comercias.

Chegou-se enfim à conclusão de que a criação do Banco Central, como órgão público especialmente voltado aos problemas monetários brasileiros, seria imprescindível para o desenvolvimento do país.

\footnotetext{
${ }^{307}$ VENÂNCIO FILHO, Alberto. op. cit., p. 371. O esforço que se observa nos países subdesenvolvidos no sentido de elevar rapidamente o nível de vida de suas populações vai fazer surgir uma legislação que procura fornecer os instrumentos normativos para favorecer rapidamente o processo de enriquecimento desses países.

${ }^{308}$ Depoimento de DÊNIO NOGUEIRA constante da obra: BULHÕES, Octavio Gouvêa. op. cit., p. 259-260.

${ }^{309}$ VENÂNCIO FILHO, Alberto. op. cit., p. 281.
} 
(...) os problemas monetários de qualquer comunidade exigem a presença e ação de um órgão ou de um sistema especificamente preocupado com eles e voltado ao seu estudo. Não satisfazem esse imperativo as atenções e cuidados ocasionais de instituições cujo fulcro de ação seja diverso como é o caso, por exemplo, do Banco do Brasil, fundamentalmente um grande banco comercial, agrícola e de fomento, justamente orgulhos de usa atividade nos campos a que se dedica, e por isso mesmo distante e dessintonizado com os problemas da estabilidade monetária. ${ }^{310}$

De fato, a ditadura militar, utilizando-se de seus poderes excepcionais, viabilizou o surgimento de uma estrutura que já vinha sendo operacionalizada e discutida desde 1930/40. Todavia, não sem fazer concessões, conforme será possível verificar em seguida.

\subsubsection{O Banco Central e o Tesouro Nacional}

A edição da Lei 4595/64 trouxe muitas inovações positivas em termos de estruturação do sistema, mas também trouxe alguns paradoxos que afetaram diretamente a questão da política monetária; por exemplo, o fato de o Banco do Brasil ter-se mantido com algumas das atribuições típicas de banco central ou mesmo o fato de o Banco Central ter assumido a atípica função de fomento ao crédito rural ${ }^{311}$.

Com efeito, o Banco do Brasil que, conforme visto, sempre representou um verdadeiro entrave à criação do Banco Central, não chegou a perder seu poder, tendo em vista que logo após a edição da nova lei, utilizando-se do argumento da necessidade de operacionalizar uma "transição", acabou por manter-se como autoridade monetária em

\footnotetext{
${ }^{310}$ VIDIGAL, Geraldo de Camargo. op. cit., p. 65.

${ }^{311}$ Essa função de fomento ao crédito rural pelo Banco Central foi regulamentada pela Lei 4829.

Art. 5. - O cumprimento das deliberações do Conselho Monetário Nacional, aplicáveis ao crédito rural, será dirigido, coordenado e fiscalizado pelo Banco Central da República do Brasil.

Art. $6^{\circ}$ - Compete ao Banco Central da República do Brasil, como órgão de controle do sistema nacional do crédito rural:

I - sistematizar a ação dos órgãos financiadores e promover a sua coordenação com os que prestam assistência técnica e econômica ao produtor rural;

II - elaborar planos globais de aplicação do crédito rural e conhecer sua execução, tendo em vista a avaliação dos resultados para a introdução de correções cabíveis;

III - determinar os meios adequados de seleção e prioridade na distribuição do crédito rural e estabelecer medidas para o zoneamento dentro do qual devem atuar os diversos órgãos financiadores em função dos planos elaborados;

IV - incentivar a expansão da rede distribuidora do crédito rural, especialmente através de cooperativas; V - estimular a ampliação dos programas de crédito rural, mediante financiamento aos órgãos participantes da rede distribuidora do crédito rural, especialmente aos bancos com sede nas áreas de produção e que destinem ao crédito rural mais de $50 \%$ (cinqüenta por cento) de suas aplicações.
} 
concorrência com o Banco Central por mais duas décadas, por meio da utilização da Conta-Movimento.

A extinção da Conta-Movimento em 1986 e a criação da Secretaria do Tesouro Nacional (que absorveria as funções de execução orçamentária) possibilitaram que as contas tanto do Banco do Brasil quanto do Banco Central se tornassem mais transparentes e fosse possível o seu controle.

Em 1988, com a promulgação da nova Constituição Federal, ficaram estabelecidas as competências de cada uma dessas instituições, conforme se detalha a seguir.

No artigo $164^{312}$, dispõe-se sobre o monopólio do Banco Central para a emissão de moeda, vedando a concessão de empréstimos ao Tesouro Nacional e a outras instituições não-financeiras, mas autorizando a compra e venda de títulos do próprio Tesouro, para regular a oferta de moeda ou a taxa de juros. Dispõe-se, além disso, sobre o depósito das disponibilidades de caixa da união no Banco Central.

Pode-se analisar o referido artigo, de duas perspectivas distintas. A primeira delas para identificar a delimitação clara das funções a serem desempenhadas pelo Banco Central: ele deve deter o monopólio de emissão monetária, mas não deve poder, ao mesmo tempo, financiar a dívida pública (atribuição que no passado lhe foi conferida).

Ao dispor que não concederá empréstimos a nenhuma outra instituição não financeira, constitui-se como o banco dos bancos, uma vez que o dispositivo autoriza tacitamente o empréstimo às instituições financeiras.

Ao permitir a compra e venda de títulos públicos, o dispositivo constitucional confere um poderoso poder-instrumento para a execução da política monetária e creditícia, conforme se verificou no capítulo anterior.

Finalmente, quando o referido artigo estabelece que os recursos do Governo serão depositados no Banco Central, declara-o banqueiro do governo.

\footnotetext{
${ }^{312} \mathrm{CF} / 88$ - Art. 164. A competência da União para emitir moeda será exercida exclusivamente pelo banco central.

$\S 1 .^{\circ}$ - É vedado ao banco central conceder, direta ou indiretamente, empréstimos ao Tesouro Nacional e a qualquer órgão ou entidade que não seja instituição financeira.

$\S 2^{\circ}$ - O banco central poderá comprar e vender títulos de emissão do Tesouro Nacional, com o objetivo de regular a oferta de moeda ou a taxa de juros.

$\S 3^{\circ}$ - As disponibilidades de caixa da União serão depositadas no banco central; as dos Estados, do Distrito Federal, dos Municípios e dos órgãos ou entidades do Poder Público e das empresas por ele controladas, em instituições financeiras oficiais, ressalvados os casos previstos em lei.
} 
A outra perspectiva, com a qual é possível a análise desse artigo, evidencia-se pela interpretação sistemática do dispositivo. Note-se que ele integra o primeiro item do Capítulo referente às finanças públicas. Ao vedar expressamente a concessão de empréstimos ao Tesouro Nacional, a Constituição pretende derrubar uma relação incestuosa entre aquele que emite a moeda e aquele que a despende.

No entanto - e aí cabe a reflexão -, no dispositivo seguinte, permite-se a compra e venda dos títulos emitidos pelo Tesouro, com a restrição de que isso somente deverá ocorrer para regular a oferta de juros e moeda - dependendo, portanto, de uma série de variantes conjunturais e, especialmente, de quem fará esse controle.

Certamente reside aí uma via oculta (mas não tanto) de financiamento do Governo, uma vez que, com o pretexto de bem desempenhar a política monetária, o Banco Central pode adquirir a quantidade de títulos públicos que bem entender, tornando-se fonte de financiamento da dívida pública. Portanto, depois de tantas mudanças normativas a fim de se encerrar a possibilidade de que o Banco Central financie a dívida pública, ainda hoje essa situação é viável, pela própria Constituição Federal.

\subsubsection{O Papel das Instituições Financeiras na Execução da Política Monetária}

Conforme esclarecido por De Chiara ${ }^{313}$, por serem “o quartel general do crédito”, das instituições financeiras depende o desenvolvimento econômico de uma nação. Por meio do desempenho de uma correta política de crédito é possível proporcionar capital às empresas para que elas busquem a inovação e, consequentemente, o incremento da atividade produtiva e, portanto, o desenvolvimento social. Conforme destacou-se no capítulo II, sem que haja uma política de crédito adequada, não é possível que se conceba um país desenvolvido.

A Lei 4595/64, nos termos do inciso IV, do artigo $3^{\text {o314 }}$, determinou que cabe ao Conselho Monetário Nacional direcionar a aplicação dos recursos movimentados pelas

\footnotetext{
${ }^{313}$ DE CHIARA, José Tadeu. Disciplina jurídica das instituições financeiras, cit., p. 290. Essa possibilidade de incorporação, da disposição de bens e recursos ainda não produzidos, é concretizada pelo crédito. $\mathrm{Na}$ verdade é pelo instrumento do crédito, entendido do aspecto monetário, que podem os empresários aperfeiçoar-se e aprimorar as respectivas unidades produtivas, inovando no seio do sistema econômico e promovendo a alternativa de ganhos qualitativos, fundamentalmente, e quantitativos, conseqüentemente.

${ }^{314}$ Art. $3^{\circ}$ A política do Conselho Monetário Nacional objetivará: (...)
} 
instituições financeiras, para propiciar investimentos na atividade produtiva, nas distintas regiões do país, proporcionando condições favoráveis ao desenvolvimento. Adicionalmente, cabe ao Conselho Monetário Nacional propiciar o aperfeiçoamento dessas instituições tornando-as eficientes e zelando pela sua liquidez e solvência a fim de conferir maior higidez e estabilidade ao sistema e para que elas possam colaborar com o direcionamento da poupança para as atividades produtivas.

O Banco Central, por sua vez, tem o dever de fiscalizar ${ }^{315}$ essas instituições a fim de zelar para que cumpram as finalidades legalmente estabelecidas no momento de sua estruturação, bem como estabelecer todas as condições necessárias para a sua constituição no país. Como lecionou De Chiara:

Os bancos e particular e o sistema bancário de forma geral são compreendidos como fatores importantíssimos do aparelhamento do Estado para o desempenho de sua ação nos mercados e, por via de conseqüência, para poder realizar o ideal social que lhe é acometido. A disciplina do sistema financeiro surge das regras mestras determinadas pela lei, mas encontra um nível elevado de especificidade e minuciosidade nas normas emanadas do Conselho monetário e do Banco Central $^{316}$.

Resta saber se o movimento de internacionalização das instituições financeiras, iniciado com a abertura do mercado na década de 1990, não prejudicou de alguma forma a consecução dos objetivos dispostos na Lei, uma vez que o comprometimento com o

IV - Orientar a aplicação dos recursos das instituições financeiras, quer públicas, quer privadas; tendo em vista propiciar, nas diferentes regiões do País, condições favoráveis ao desenvolvimento harmônico da economia nacional;

V - Propiciar o aperfeiçoamento das instituições e dos instrumentos financeiros, com vistas à maior eficiência do sistema de pagamentos e de mobilização de recursos;

VI - Zelar pela liquidez e solvência das instituições financeiras; (...).

${ }^{315}$ Art. 10. Compete privativamente ao Banco Central da República do Brasil: (...)

IX - Exercer a fiscalização das instituições financeiras e aplicar as penalidades previstas;

$\mathrm{X}$ - Conceder autorização às instituições financeiras, a fim de que possam:

a) funcionar no País;

b) instalar ou transferir suas sedes, ou dependências, inclusive no exterior;

c) ser transformadas, fundidas, incorporadas ou encampadas;

d) praticar operações de câmbio, crédito real e venda habitual de títulos da dívida pública federal, estadual ou municipal, ações Debêntures, letras hipotecárias e outros títulos de crédito ou mobiliários;

e) ter prorrogados os prazos concedidos para funcionamento;

f) alterar seus estatutos.

g) alienar ou, por qualquer outra forma, transferir o seu controle acionário.

XI - Estabelecer condições para a posse e para o exercício de quaisquer cargos de administração de instituições financeiras privadas, assim como para o exercício de quaisquer funções em órgãos consultivos, fiscais e semelhantes, segundo normas que forem expedidas pelo Conselho Monetário Nacional.

${ }^{316}$ DE CHIARA, José Tadeu. Disciplina jurídica das instituições financeiras, cit., p. 290. 
desenvolvimento equilibrado do país pode não estar na ordem do dia das instituições americanas e europeias, o que até faz sentido do ponto de vista de tais instituições.

Neste ponto, cumpre notar que a Lei 4595/64 deixa clara a possibilidade de que o Estado, por meio do Conselho Monetário Nacional e do Banco Central, intervenha na economia buscando os objetivos de promoção social e desenvolvimento.

Isso implica dizer que o Estado tem o dever de arregimentar as instituições financeiras (independentemente de sua nacionalidade, desde que estejam aqui sediadas) para que elas comprometam-se e corroborem ativamente com o exercício da política monetária. Cabe ao Estado, portanto, utilizá-las como suporte para o alcance de seus objetivos especialmente no que tange ao direcionamento do crédito.

\subsubsection{O Banco Central do Brasil e o CMN - A questão da Autonomia}

Num passado recente, diversos países decidiram isolar as deliberações das autoridades monetárias do contexto sociopolitico na qual se inserem, em nome da busca prioritária pela estabilidade da moeda. Isso gerou o debate sobre a necessidade de se conferir autonomia aos bancos centrais.

O tema foi, em larga medida, abordado no capítulo anterior e, na opinião desta autora, os objetivos da política monetária levados a efeito pelo Banco Central devem, necessariamente, estar submetidos às razões de Estado, coordenados com a política econômica em geral, sempre observada a necessária transparência.

No Brasil, diferentemente de outros países nos quais o Banco Central nasce subordinado ao Poder Legislativo, naturalmente por ser órgão executor de políticas públicas legisladas, com o golpe militar de 1964, a organização do Banco Central deu-se não de acordo com a Constituição Federal de 1946, em vigor na época, mas sob a sombra de um regime ditatorial e, portanto, visceralmente ligado com o Poder Executivo. Nesse sentido, a primeira organização do Banco Central no Brasil deu origem a um órgão cujos membros eram nomeados e demissíveis ad nutum. Sua administração era organizada pelo Chefe do Poder Executivo e sob os desígnios de um conselho obviamente compromissado com o regime militar. 
Quanto à questão da autonomia do Banco Central do Brasil, portanto, cumpre dizer que se trata de tema em voga desde a sua origem, dado ter sito instituído desta maneira peculiar e tão intimamente ligada ao Poder Executivo. Paul Hugon, ao comentar a então recente reforma bancária de 1964, destacou o seguinte:

É evidente - como verificamos muitas vezes no decorrer da evolução monetária do Brasil - que, quando as autoridades monetárias dependem muito estritamente do Govêrno, abusos tornam-se inevitáveis, em particular no domínio da emissão. Convinha, portanto, dar ao Conselho Monetário e a seu órgão de execução, o Banco Central, uma certa independência. Mas era impossível torná-los completamente independentes do Governo: suas funções essenciais consistindo em fornecer os meios de pagamento e de regulamentação do crédito, seu papel é sem dúvida de primeira importância no funcionamento do sistema monetário, mas não pode escapar à orientação geral do Governo. Nenhum banco central do mundo, aliás, escapa a essa orientação ${ }^{317}$. (Grifou-se)

Importante ponderar que não é o escopo deste trabalho discutir o fato de que a tecnocracia tem (ou não) amplas condições de, utilizando-se de métodos previamente definidos e estudados, atuar com eficiência para atingir os objetivos da política monetária. A questão que se coloca mais propriamente consiste em identificar a quem compete definir tais objetivos, quais são os limites de utilização dos instrumentos monetários, qual é o tipo de controle exercido sobre esta atuação, qual a sua representatividade.

Nos termos do artigo $7^{\circ}$ da Lei 4595, tal como ocorre com o Federal Reserve, foram instituídas Comissões técnicas cujo objetivo seria nortear as decisões do CMN de acordo com as principais necessidades dos setores mais representativos da sociedade, a fim de possibilitar a formulação de uma política monetária e creditícia mais próxima da realidade.

As Comissões Consultivas instituídas pela Lei seriam quatro: (i) Bancária, (ii) de Mercado de Capitais, (iii) de Crédito Rural e (iv) de Crédito Industrial, cuja regulamentação dependeria de expedição de norma pelo CMN.

\footnotetext{
${ }^{317}$ HUGON, Paul. A moeda: introdução à análise e às políticas monetárias e à moeda no Brasil, cit., p. 194. Outro autor, ainda em 1964, ano da criação do Banco Central, apresenta posição mais inclinada à defesa independência do nascente Banco como órgão técnico que precisa atuar livre de pressões políticas: Face, porém, à mobilidade da economia, indispensável se faz atribuir aos órgãos de direção monetária condições de ação pronta e eficiente. Se tal direção for burocratizada ou sujeita a controles políticos, os remédios indicados para uma conjuntura só receberão aprovação quando ela já se houver modificado. As condições desejáveis só se apresentam quando os órgãos de direção monetária gozam de independência, autoridade e estabilidade. VIDIGAL, Geraldo de Camargo. op. cit., p. 56.
} 
Nos dizeres de De Chiara:

Com efeito, ressaltamos o papel das comissões consultivas bancárias do mercado de capitais, de crédito rural e de crédito industrial que exercem aquele assessoramento nos campos de área financeira de grande especialidade. Esse caráter técnico pretende afastar a possibilidade do livre jogo de interesses políticos e, algumas vezes particulares, atuando na direção de entes diretivos da política monetária ${ }^{318}$.

Todavia, tais Comissões não chagaram a ser efetivamente regulamentadas, tampouco o CMN conduziu a política monetária auxiliado por elas.

Passadas três décadas, com a edição do Plano Real, Lei 9069 de 29.06.1995, houve nova tentativa de instituição das Comissões Consultivas de acordo com as seguintes subdivisões, nos termos do artigo 11: (i) de Normas e Organização do Sistema Financeiro; (ii) de Mercado de Valores Mobiliários e de Futuros; (iii) de Crédito Rural; de Crédito Industrial; (iv) de Crédito Habitacional e para Saneamento e Infraestrutura Urbana; (v) de Endividamento Público; (vi) de Política Monetária e Cambial as quais teriam a organização, a composição e o funcionamento determinados por regimento interno, a ser aprovado por Decreto do Presidente da República.

Embora tenha sido expedido o Decreto Presidencial 1307 de 09.11.1994, com o objetivo de regulamentar tais Comissões Consultivas, determinando que competiria a elas $^{319}$, entre outras atribuições, apreciar matérias atinentes às suas finalidades; propor alteração de seu regimento interno ao $\mathrm{CMN}$; convidar representantes de entidades públicas ou privadas para participarem de suas reuniões, na prática nunca foram utilizadas como mecanismos de representatividade para auxiliar formulação das políticas monetárias pelo CMN, ficando, com o passar do tempo, esquecidas.

Sem dúvida que este seria um mecanismo hábil a conferir legitimidade e representatividade às decisões do $\mathrm{CMN}$, que poderia ter garantida a sua autonomia, desde que atuando em consonância com o auxílio destas comissões, e, claro, de acordo com as diretivas gerais da política econômica constitucionalmente prevista.

Com efeito, da análise da Lei 4595 em conjunção com o disposto sobre o Banco Central na Constituição Federal (que, aliás, é a primeira das constituições a tratar

\footnotetext{
${ }^{318}$ DE CHIARA, José Tadeu. Disciplina jurídica das instituições financeiras, cit., p. 295.

${ }^{319}$ Art. 11 - Compete às Comissões Consultivas, dentre outras atribuições previstas em seu regimento interno:

I - por solicitação do $\mathrm{CMN}$ ou da COMOC, apreciar matérias atinentes às suas finalidades;

II - propor alteração em seu regimento interno, ao CMN;

III - convidar pessoas ou representantes de entidades públicas ou privadas para participar de suas reuniões.
} 
especificamente do tema), verifica-se que a composição do Sistema Financeiro Nacional estaria perfeitamente de acordo com o que vem sendo defendido neste trabalho, especialmente no Capítulo II, a respeito da necessária observância pelo Banco Central das diretrizes gerais da política econômica, por tratar-se de elemento essencial à viabilização de tal política.

Com efeito, a Constituição Federal, promulgada quase trina anos depois da Lei 4595, possui previsões específicas no que tange à relação entre o Banco Central e os Poderes da União ${ }^{320}$.

Os artigos 52, inciso III, alínea "d" ${ }^{321}$ e 84, inciso XIV ${ }^{322}$, da Constituição Federal que dispõem sobre a escolha dos diretores e presidente do Banco Central, determinam que esta deverá ocorrer, primeiramente, pela aprovação pelo Senado Federal e, depois, pela nomeação do Presidente da República.

O ato de aprovação privativa pelo Senado, por meio de voto secreto, após arguição pública, tem conteúdo jurídico bastante especial. Os senadores são eleitos na qualidade de representantes da federação e, por esse motivo, ao aprovarem o corpo diretivo do principal componente do Sistema Financeiro Nacional conferem legitimidade a ele. Esse tipo de "sabatina" por parte do Poder Legislativo eleva a função, que originalmente poderia ser exercida e chefiada por um corpo técnico de burocratas contratados, ao patamar elevado de representatividade que se verifica, deixando transparecer a compreensão de que tal função de decidir sobre os destinos da política monetária não é meramente técnica, mas política também.

Com efeito, a "aprovação" do Poder Legislativo - representado neste caso pelo Senado Federal - é a legitimação que se funda no mérito, imbuindo de responsabilidade os condutores do Sistema Financeiro Nacional, reconhecendo-se formalmente o papel de extrema relevância social por eles desempenhado.

A nomeação pelo Presidente da República, ato posterior e condicionado à aprovação do Senado, tem certamente um caráter de subordinação, uma vez que o

\footnotetext{
${ }^{320} \mathrm{CF} / 88$ - Art. $2^{\circ}$ São Poderes da União, independentes e harmônicos entre si, o Legislativo, o Executivo e o Judiciário.

${ }^{321} \mathrm{CF} / 88$ - Art. 52. Compete privativamente ao Senado Federal:

III - aprovar previamente, por voto secreto, após argüição pública, a escolha de: (...)

d) Presidente e diretores do banco central;

${ }^{322}$ Art. 84. Compete privativamente ao Presidente da República:

XIV - nomear, após aprovação pelo Senado Federal, os Ministros do Supremo Tribunal Federal e dos Tribunais Superiores, os Governadores de Territórios, o Procurador-Geral da República, o presidente e os diretores do banco central e outros servidores, quando determinado em lei;
} 
Presidente é o Chefe do Poder Executivo, atribuindo característica de confiança ao vocábulo "nomear".

A interpretação dos dois dispositivos constitucionais em conjunto, os artigos 52, inciso III, alínea “d” e 84, XIV leva à conclusão de que o presidente do Banco Central do Brasil e seus diretores, ao exercerem funções de tamanha relevância perante a sociedade brasileira, têm o dever de prestar contas à sociedade, corporificada neste caso pelo Senado Federal (Poder Legislativo), e pelo Presidente da República (Poder Executivo), atuando de forma consonante com esses Poderes Estatais.

Conclui-se desta breve análise a respeito das disposições constitucionais acerca do Banco Central que este não deve ser um órgão autônomo, capaz de sozinho decidir quais os objetivos da política monetária.

Corroborando esse entendimento, na perspectiva do Direito Administrativo, o Banco Central foi instituído sob a forma de autarquia federal ${ }^{323}$, estando sujeito ao direito público quanto a sua criação, extinção, poderes, prerrogativas privilégios e sujeições.

Sendo autarquia, o Banco Central não goza de autonomia por estar adstrito à capacidade de se autoadministrar nos limites das matérias específicas a ele designadas pela pessoa pública política que determinou a sua criação. Exerce, portanto, um serviço público descentralizado sujeito ao controle e tutela do Estado a fim de que esse possa assegurar que a função atribuída está sendo adequadamente exercida ${ }^{324}$.

Assim, embora exista, também no Brasil, o apego à teoria de que um banco central independente resolveria todos os problemas da política monetária, verifica-se que entre as formas nas quais podem revestir-se as figuras da administração indireta, a autarquia é a melhor delas. Isso porque a autarquia, por natureza, está normativamente investida da obrigação de perseguir os interesses da coletividade.

\footnotetext{
${ }^{323}$ Decreto-lei n. ${ }^{\text {o } 200 / 67 ~-~ a r t . ~ 5 . ~}{ }^{\text {P }}$ Para os fins desta lei, considera-se:

I - Autarquia - o serviço autônomo, criado por lei, com personalidade jurídica, patrimônio e receita próprios, para executar atividades típicas da Administração Pública, que requeiram, para seu melhor funcionamento, gestão administrativa e financeira descentralizada.

${ }^{324}$ Sobre as autarquias assim dispõe DI PIETRO, Maria Sylvia Zanella. Direito administrativo. 14 ed. São Paulo: Atlas, 2002. p. 369, Perante a Administração Pública centralizada, a autarquia dispõe de direitos e obrigações; isto porque, sendo instituída por lei para desempenhar determinado serviço público, do qual passa a ser titular, ela pode fazer valer, perante a Administração, o direito de exercer aquela função, podendo opor-se às interferências indevidas; vale dizer que ela tem o direito ao desempenho do serviço nos limites definidos em lei. Paralelamente, ela tem a obrigação de desempenhar suas funções; originariamente, essas funções seriam do Estado, mas este preferiu descentralizá-las a entidades às quais atribuiu personalidade jurídica, patrimônio próprio e capacidade administrativa; essa entidade torna-se responsável pela prestação do serviço; em conseqüência, a administração centralizada tem que exercer controle para assegurar que a função seja exercida.
} 
Além disso, no que tange a sua relação com terceiros, por ser autarquia, o Banco Central possui a mesma carga de responsabilidade atribuída à Administração direta, dado que exerce, em nome desta, função específica regulamentada por meio de lei. Logo, o Banco Central, com natureza de autarquia, perante terceiros desfruta das mesmas prerrogativas, poderes deveres e sujeições a que se vincula o Estado, como se este estivesse atuando diretamente ${ }^{325}$.

Visto o tema na perspectiva do Direito Constitucional e Administrativo, cabe voltar ao Direito Econômico ${ }^{326}$ no que tange à legitimidade para a execução da política monetária a fim de analisar de que forma o assunto tem sido tratado quanto à autonomia do Banco Central.

Nos termos da legislação específica a respeito dos instrumentos da política monetária no Brasil, relativamente às atribuições do Conselho Monetário Nacional, o art. 4. ${ }^{\circ}$ da Lei $n^{\circ} 4.595 / 64$, prescreve:

Art. 4. ${ }^{\circ}$ Compete ao Conselho Monetário Nacional, segundo as diretrizes estabelecidas pelo Presidente da República: (...)

V - Fixar as diretrizes e normas da política cambial, inclusive quanto à compra e venda de ouro e quaisquer operações em Direitos Especiais de Saque e em moeda estrangeira.(...)

IX - Limitar, sempre que necessário, as taxas de juros, descontos, comissões e qualquer outra forma de remuneração de operações e serviços bancários ou financeiros, inclusive os prestados pelo Banco Central do Brasil (...);

XVII - Regulamentar, fixando limites, prazos e outras condições, as operações de redesconto e de empréstimo, efetuadas com quaisquer instituições financeiras públicas e privadas de natureza bancária;

XIX - Estabelecer normas a serem observadas pelo Banco Central da República do Brasil em suas transações com títulos públicos e de entidades de que participe o Estado;

Conforme o disposto no artigo acima, o Conselho Monetário Nacional exerceria função regulatória, despojada de caráter executivo, reunindo condições para traçar diretrizes com vistas a combinar os instrumentos monetários às demais ferramentas de orientação e defesa da economia brasileira. Sua atividade estaria atrelada às atribuições de formulação da política monetária, portanto.

\footnotetext{
${ }^{325}$ MELLO, Celso Antônio Bandeira de. op.cit., p. 147 e ss.

${ }^{326}$ Observada a ressalva de que o Direito Econômcio, como visto no capítulo primeiro, não é mero ramo do direito formal e não pode ser classificado e rotulado de acordo com as matérias que regula.
} 
Por sua vez, o Banco Central seria um órgão mais técnico, responsável por aplicar adequadamente as decisões do Conselho.

Todavia, com a promulgação da Constituição Federal, pelo artigo 25, caput e inciso I, do Ato das Disposições Constitucionais Transitórias (ADCT), revogou-se expressamente o poder de delegação do Executivo em atos de competência do Congresso Nacional, inclusive no que tange à capacidade normativa, conferindo o prazo de 180 (cento e oitenta) dias para vigência dessa revogação.

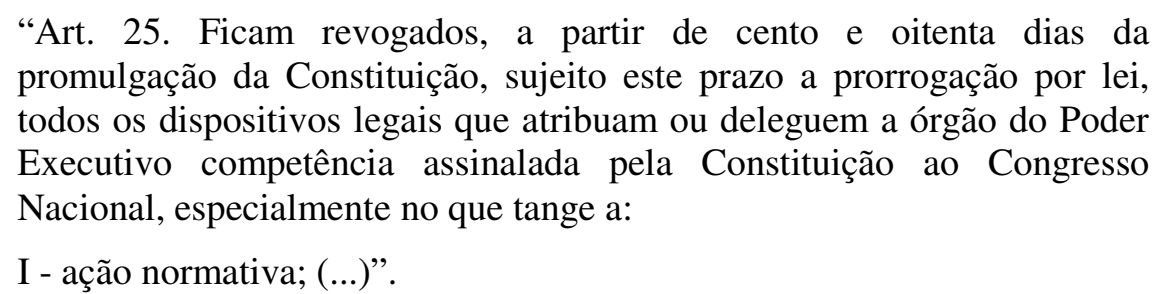

Além disso, a Constituição Federal atribuiu ao Congresso Nacional a função de regular a política monetária a ser exercida pelo Banco Central, não fazendo sequer menção à existência de Conselho Monetário Nacional: Art. 48. Cabe ao Congresso Nacional, com a sanção do Presidente da
República, não exigida esta para o especificado nos arts. 49,51 e 52 ,
dispor sobre todas as matérias de competência da União, especialmente
sobre: (...)
XIII - matéria financeira, cambial e monetária, instituições financeiras e
suas operações;
XIV - moeda, seus limites de emissão, e montante da dívida mobiliária
federal.

Passados 180 dias da promulgação da Constituição Federal, prazo previsto no caput do art. 25 do ADCT, seguiram-se sucessivas medidas provisórias e leis (MPs n. ${ }^{\circ}$ 45, de 31.03 .89 n. $^{\text {o }} 53.100$ e n. ${ }^{\circ} 188$ e Leis 7.770/89; 7.892/89; 8.056/90; 8.127/90; 8.201/91) com o objetivo de dar sobrevida ao Conselho Monetário Nacional e à sua capacidade normativa. Por fim, a Lei 8.392/91 estendeu o período de delegação da capacidade do poder normativo do Executivo até a data da promulgação da lei complementar sobre o sistema financeiro nacional, a qual somente teria ocorrido se fosse regulamentado o artigo 192 e seus incisos.

Como isso nunca ocorreu, tendo sido, inclusive, o mencionado artigo alterado pela emenda Constitucional $\mathrm{n}^{\circ} 40$ de 2003 , de modo que não mais houvesse menção à tal lei complementar que deveria ser editada com o objetivo de promover o desenvolvimento do 
país, continuou em vigor o art. $4 .^{\circ}$, inciso IX, da Lei 4.595/64, em evidente conflito com a Constituição Federal.

Um novo capítulo dessa história iniciou-se em 20 de junho de 1996. Em consonância com todas as demais medidas liberalizantes ocorridas na década, abriu-se a oportunidade para a denominada "autonomia operacional do Banco Central". Criou-se o Comitê de Política Monetária (COPOM), composto somente por membros do Banco $\underline{\text { Central, }}$ com o objetivo de estabelecer as diretrizes da política monetária e de definir a taxa de juros.

Atualmente, tendo em vista essa alteração, alguns entendem que o Banco Central passou a gozar de sua tão almejada autonomia, o que equivale a dizer que operacionalmente possuiria liberdade para atuar, adotando técnicas e expertise de seus burocratas a fim de aplicar, da "melhor maneira", as diretrizes do Poder Executivo.

A justificativa dada pelo Banco Central $^{327}$ para a criação do Comitê está no direito comparado, pois existem estruturas similares nos EUA e na Alemanha: Federal Open Market Committee (FOMC) do FED e o Central Bank Council do Banco Central da Alemanha. Todavia essa justificativa apenas seria plausível se não houvesse norma expressa a respeito de quais são as competências do Banco Central do Brasil e a quem compete o "processo decisório" e normativo de política monetária.

Com efeito, o Regulamento do COPOM foi instituído por meio de uma Circular do Banco Central $^{328}$, norma hierarquicamente inferior à Lei 4595/64 a qual atribuiu ao Conselho Monetário Nacional, e não ao Banco Central, a formulação da política monetária

\footnotetext{
${ }^{327}$ Conforme o sítio do Banco Central: Em um regime de metas para a inflação, é necessário que haja autonomia operacional do Banco Central, de maneira que este possa gerir a política monetária no sentido do cumprimento das metas. Além disso, é necessário que a situação fiscal esteja sob controle, e que o sistema financeiro nacional esteja estável, de modo a não comprometer a perseguição da meta para a inflação.

E, nesse mesmo site, especificamente quanto à criação do Comitê de Política Monetária:

A criação do Comitê buscou proporcionar maior transparência e ritual adequado ao processo decisório, a exemplo do que já era adotado pelo Federal Open Market Committee (FOMC) do Banco Central dos Estados Unidos e pelo Central Bank Council do Banco Central da Alemanha. Em junho de 1998, o Banco da Inglaterra também instituiu o seu Monetary Policy Committee (MPC), assim como o Banco Central Europeu, desde a criação da moeda única em janeiro de 1999. Atualmente, uma vasta gama de autoridades monetárias em todo o mundo adota prática semelhante, facilitando o processo decisório, a transparência e a comunicação com o público em geral. (grifou-se). BANCO CENTRAL DO BRASIL. Definição $e$ histórico. Disponível em: <http://www.bcb.gov.br/?COPOMHIST>. Acesso em: 20 nov. 2009.

${ }^{328}$ Atual Circular Circular 3.297, de 31.01. 2005

Regulamento anexo

Art. $1^{\circ}$ O Comitê de Política Monetária (COPOM), constituído no âmbito do Banco Central do Brasil, tem como objetivos implementar a política monetária, definir a meta da Taxa SELIC e seu eventual viés e analisar o Relatório de Inflação a que se refere o Decreto 3.088, de 21 de junho de 1999.

Art. $2^{\circ}$ São membros do Copom o Presidente e os Diretores do Banco Central do Brasil.
} 
brasileira. E a Lei 4595/64, por sua vez, como visto no tópico anterior, também coexiste em evidente conflito com norma hierarquicamente superior: a Carta Magna (art. 48).

Nesse sentido, a Constituição Federal e a Lei 4596/64 jamais conferiram ao Banco Central a possibilidade de instituir um "processo decisório" de política monetária do qual somente o seu presidente e diretores participem em completo isolamento. Está muito claro que cabe ao Banco Central, exclusivamente, a execução da política monetária formulada e definida pelo Congresso Nacional, nos termos da Constituição, ou, que seja, pelo Conselho Monetário Nacional, nos termos da Lei 4596/64.

Portanto, ao analisar-se o caso em qualquer perspectiva conclui-se, inevitavelmente, que as decisões tomadas por esse Comitê são não só ilegítimas como ilegais. Por maneiras enviesadas que expõem a evidente desconformidade desse processo, atualmente, no Brasil, quem define, executa e controla a política monetária é o Banco Central, prescindindo para tanto da participação de Comissões Consultivas, Conselho Monetário Nacional e, menos ainda, do Congresso Nacional.

Daí conclui-se que, concretamente, a autonomia com características de independência foi efetivamente conquistada pelo Banco Central $^{329} \mathrm{o}$ qual atua hoje livre de todos controles institucionais criados pelo arcabouço jurídico pátrio.

\subsection{A Política Monetária Brasileira e o Regime de Metas para a Inflação}

Conforme visto, até 1945 o Banco do Brasil fazia as vezes de Banco Central, conciliando as funções públicas com as atividades de banco comercial. Posteriormente, foi criada a Superintendência da Moeda e do Crédito (SUMOC) que passou a dividir com o

\footnotetext{
${ }^{329}$ Atualmente está em trâmite no Senado Federal o Projeto de Lei102, de 2007, o qual objetiva a regulamentação do Sistema Financeiro Nacional (SFN), em substituição à Lei $n^{\circ} 4.595 / 64$, com vistas à ampliar a participação do Congresso Nacional na fiscalização das políticas monetária e cambial do país. Este projeto e é constituído de nove seções. As três primeiras seções determinam as normas gerais para o SFN. A primeira seção discorre sobre as atribuições do Conselho Financeiro Nacional (CFN), criado em substituição ao Conselho Monetário Nacional $(\mathrm{CMN})$. A segunda seção trata das características e atribuições do Banco Central do Brasil (BCB), dispondo inclusive sobre sua autonomia e sobre os mandatos fixos de seu presidente e diretores e a terceira seção trata das instituições financeiras. A quarta seção regulamenta o sistema de garantia de depósitos e aplicações. A quinta seção trata do sigilo de dados. A sexta seção regulamenta os regimes especiais de intervenção, o regime de administração especial temporária e de liquidação judicial. A sétima seção discorre sobre as penalidades aplicáveis às instituições participantes do SFN. A oitava seção trata das disposições transitórias e a nona seção das disposições finais. Em 09/12/2009 a Comissão de Constituição, Justiça e Cidadania (CCJ) aprovou o Projeto de Lei.
} 
Banco do Brasil algumas das atividades que configurariam as funções clássicas de um banco central.

A alteração deste cenário ocorreu com a edição da Lei 4595, de 31.12.1964, que estabeleceu as diretrizes fundamentais para a organização do "Sistema Financeiro Nacional", determinando a composição, organização e competência de cada uma das instituições integrantes desse sistema, bem como os objetivos a serem seguidos pela política monetária brasileira.

Em sua exposição de motivos, assim ficaram estabelecidos os fundamentos legitimadores da aprovação e edição da referida lei:

Promover as modificações no regime jurídico das instituições financeiras privadas de modo que sua atuação contribua para a utilização mais eficiente dos recursos financeiros nacionais, promover distribuição mais eqüitativa desses recursos, e facilitar o desenvolvimento harmônico das diferentes regiões do país. ${ }^{330}$

Tais fundamentos estão também estampados nos incisos primeiro e quarto de seu artigo $3 .^{\text {o331 }}$, destacando-se como objetivo principal do Sistema Financeiro Nacional a adaptação dos meios de pagamento às necessidades da economia nacional, para ser possível alavancar o desenvolvimento do país.

Com efeito, a edição da Lei da Reforma Bancária procurou estruturar o Sistema Financeiro Nacional, tendo instituído o Conselho Monetário Nacional e o Banco Central do Brasil, como seus pilares fundamentais, conferindo-lhes competência para, respectivamente, formular e executar a política monetária, e, adicionalmente, fiscalizar as instituições financeiras.

\footnotetext{
${ }^{330}$ Fonte: ANDREZO, Andréa Fernandes; LIMA, Iran Siqueira. op. cit.

${ }^{331}$ Art. $3^{\circ}$ A política do Conselho Monetário Nacional objetivará:

I - Adaptar o volume dos meios de pagamento às reais necessidades da economia nacional e seu processo de desenvolvimento;

II - Regular o valor interno da moeda, para tanto prevenindo ou corrigindo os surtos inflacionários ou deflacionários de origem interna ou externa, as depressões econômicas e outros desequilíbrios oriundos de fenômenos conjunturais;

III - Regular o valor externo da moeda e o equilíbrio no balanço de pagamento do País, tendo em vista a melhor utilização dos recursos em moeda estrangeira;

IV - Orientar a aplicação dos recursos das instituições financeiras, quer públicas, quer privadas; tendo em vista propiciar, nas diferentes regiões do País, condições favoráveis ao desenvolvimento harmônico da economia nacional;

V - Propiciar o aperfeiçoamento das instituições e dos instrumentos financeiros, com vistas à maior eficiência do sistema de pagamentos e de mobilização de recursos;

VI - Zelar pela liquidez e solvência das instituições financeiras;

VII - Coordenar as políticas monetária, creditícia, orçamentária, fiscal e da dívida pública, interna e externa. (grifou-se).
} 
O Conselho Monetário Nacional, órgão de cúpula, foi criado para ser o responsável pela formulação das medidas concernentes ao Sistema Financeiro e o Banco Central, o executor de tais medidas. Nos termos do artigo 9. ${ }^{\circ}$ da referida norma, compete ao Banco Central cumprir e fazer cumprir as disposições que lhe são atribuídas pela legislação em vigor e pelas normas expedidas pelo Conselho Monetário Nacional.

Conforme se viu no Capítulo II, com o avanço do neoliberalismo, os Estados periféricos passaram, especialmente nas duas últimas décadas, por um período de exacerbação do exercício de uma política essencialmente monetarista ${ }^{332}$ acompanhando a tendência adotada pelos países desenvolvidos no que tange à organização das atividades do Banco Central.

Em decorrência disso, os Bancos Centrais desses países mantêm elevadas taxas de juros e o amplo endividamento externo em busca da obsessivamente almejada "estabilidade da moeda".

Com efeito, os planos do governo brasileiro, especialmente a partir da década de 1990, com a aplicação das regras definidas no Consenso de Washington ${ }^{333}$, passaram a ter como foco principal manter o controle da inflação e a estabilidade da moeda. A fixação das altas taxas de juros e realização de privatizações de empresas estatais foram medidas igualmente implantadas por muitos países da América Latina ${ }^{334}$.

No Brasil, a concepção de um mercado organizado foi tardia. Talvez por esse motivo, as incipientes estruturas formadoras do Sistema Financeiro Nacional sejam, ainda,

\footnotetext{
${ }^{332}$ NUNES, António José Avelãs. Nota sobre a independência dos Bancos Centrais, cit., p. 65.

${ }^{333}$ Assim como outros grandes países latino-americanos, até então submetidos às condições de ajuste impostas pela crise da dívida externa, o Brasil foi literalmente capturado pelo processo de globalização financeira da década de 1990. Como os demais, executou seus programas de estabilização de acordo com as normas dos mercados financeiros liberalizados, cuja regra básica é a oferta de ativos atraentes que possam ser encampados pelo movimento geral de concentração e centralização do capital à escala mundial. As aberturas comercial e financeira desenharam para o Brasil um quadro macroeconômico cuja principal característica foi o aparecimento - sobretudo a partir da segunda metade da década de 1990 - de um crescente desequilíbrio externo não apenas na balança comercial, mas também na balança de serviços. BELluZZO, Luiz Gonzaga de Mello; TAVARES, Maria da Conceição. O país flutuante. Folha de S. Paulo, São Paulo, 21 mar. 2004. Caderno Mais!

334“"A gestão monetária das estabilizações acompanhadas pelas reformas e sustentadas pelo investimento externo, tem demonstrado uma forte incompatibilidade com o crescimento econômico e tem produzido efeitos sociais e fiscais de crescente gravidade. Limitados externamente por seus balanços de pagamento negativos, estes países não conseguem desfazer-se de sua dependência do financiamento externo e, portanto, de suas altas taxas de juros responsáveis pelos baixos índices de crescimento. Como nos demais países, os bancos centrais dedicam-se a administrar dentro de sua limitada margem de manobra, o espaço de valorização financeira da riqueza privada. Os Tesouros Nacionais, por seu lado, ficam com suas contas cada vez mais comprometidas pela queda de atividade econômica e dos empregos e pela expansão das dívidas públicas. FIORI, José Luís. op. cit., v. 1, p. 140 e 142.
} 
suscetíveis a influências e comandos de autoridades financeiras externas, como no que diz respeito à adesão incondicional às regras fixadas no Consenso de Washington.

Fundada em argumentos tais como o de que a estabilidade é condição necessária e suficiente para o crescimento, ou de que a abertura comercial ao exterior é sempre virtuosa, e, ainda, que a intervenção do Estado deve ser minimizada, a ideologia liberal tomou corpo e hoje domina o pensamento político e burocrático brasileiro.

O Banco Central do Brasil adota o chamado "Regime de Metas para a Inflação" que corresponde a um regime monetário no qual se compromete a garantir que a inflação não ultrapasse determinada meta preestabelecida publicamente. Quanto a esse regime, cumpre destacar que o Brasil o adotou formalmente como diretriz da política monetária, com a edição do Decreto n. ${ }^{\circ} 3.088$ pelo Presidente da República, em 21 de junho de 1999.

O Regime de Metas para a Inflação caracteriza-se, conforme explicitado pelo Banco Central ${ }^{335}$, por quatro elementos básicos: i) conhecimento público de metas numéricas de médio-prazo para a inflação; ii) comprometimento institucional com a estabilidade de preços como objetivo primordial da política monetária; iii) estratégia de atuação pautada pela transparência para comunicar claramente o público sobre os planos, objetivos e razões que justificam as decisões de política monetária e iv) mecanismos para tornar as autoridades monetárias responsáveis pelo cumprimento das metas para a inflação.

De acordo com o regime de metas, cuja ação se baseia no controle de apenas um instrumento, a taxa de juros de curto-prazo, não é possível atribuir à política monetária, metas adicionais tais como a priorização do crescimento econômico. Só há uma prioridade, repetida como um mantra aos quatro cantos: alcançar a meta predefinida e, assim, manter estável a moeda. Assim, o regime de metas para a inflação utiliza a taxa Selic $^{336}$ como instrumento primário de política monetária. Um dos objetivos centrais dessa sistemática é o de balizar as expectativas de mercado que orientam o processo de formação de preços na economia.

\footnotetext{
${ }^{335}$ BANCO CENTRAL DO BRASIL. Sistema de Metas para a Inflação. Disponível em: <http://www.bcb.gov.br/?SISMETAS>. Acesso em: 20 nov. 2009.

${ }^{336}$ Sistema Especial de Liquidação e de Custódia - SELIC, do Banco Central do Brasil, é um sistema informatizado que se destina à custódia de títulos escriturais de emissão do Tesouro Nacional, bem como ao registro e à liquidação de operações com os referidos títulos. A taxa Selic é a taxa de juros média que incide sobre os financiamentos diários com prazo de um dia útil (overnight) lastreados por títulos públicos registrados no Sistema Especial de Liquidação e Custódia (Selic), ou seja, é a taxa de juros que equilibra o mercado de reservas bancárias. O Comitê de Política Monetária (COPOM) estabelece a meta para a taxa Selic, e cabe à mesa de operações do mercado aberto do Banco Central manter a taxa Selic diária próxima à meta. Fonte: BANCO CENTRAL DO BRASIL. Disponível em: <www.bancocentral.gov.br>.
} 
Quando as metas para a inflação não são cumpridas, isto é, quando a inflação ultrapassa os limites do intervalo de tolerância em torno da meta central, as razões para o descumprimento, bem como as providências tomadas para retornar à trajetória de metas, são enviadas pelo Presidente do Banco Central do Brasil em Carta Aberta ao Ministro da Fazenda.

Entretanto, conforme aqui se asseverou, não é essa a finalidade do exercício da política econômica estatal; trata-se somente de um meio para alcançar determinados fins. Claro que, para atingir os fins da política monetária, não se pode contar com uma moeda fraca e com patamares altíssimos de inflação.

Mas não se pode colocar as condições necessárias ao estabelecimento de uma política monetária adequada como se fossem os seus próprios fins. A estabilidade de preços não deve, portanto, ser um objetivo, mas um meio para alcançar determinados fins. Os fins a serem buscados pelo Estado e seus organismos, entre eles o banco central, devem estar relacionados com a busca pelo desenvolvimento social.

Com base no exposto, a respeito das teorias desenvolvidas por Keynes, sabe-se que o Estado, por essência, deveria sobretudo ordenar suas medidas com vistas a atingir o desenvolvimento social, por meio da geração de empregos e do aumento da capacidade produtiva.

Ainda que a Constituição Federal, conforme adiante será possível verificar, tenha sofrido alterações por meio de Emendas Constitucionais, a fim de permitir que se alcançassem os objetivos neoliberais diversas vezes destacados neste capítulo, persiste com seu espírito desenvolvimentista, disseminado por uma série de dispositivos que continuam a refletir os ideais de sua formulação.

No artigo 170 do Diploma Constitucional lançam-se as bases da ordem econômica constitucionalmente estatuída e seus princípios norteadores ${ }^{337}$ fundados na valorização do

\footnotetext{
${ }^{337} \mathrm{CF} / 88$ - Art. 170. A ordem econômica, fundada na valorização do trabalho humano e na livre iniciativa, tem por fim assegurar a todos existência digna, conforme os ditames da justiça social, observados os seguintes princípios:

I - soberania nacional;

II - propriedade privada;

III - função social da propriedade;

IV - livre concorrência;

$\mathrm{V}$ - defesa do consumidor;

VI - defesa do meio ambiente, inclusive mediante tratamento diferenciado conforme o impacto ambiental dos produtos e serviços e de seus processos de elaboração e prestação;

VII - redução das desigualdades regionais e sociais;

VIII - busca do pleno emprego;
} 
trabalho e na livre iniciativa. Bastante relevante é a percepção de que esse dispositivo está em perfeita consonância com o artigo $3^{\text {o338 }}$ que lança os fundamentos da República.

A respeito do artigo 3. ${ }^{\circ}$, manifesta-se Eros $\mathrm{Grau}^{339}$ :

"Garantir o desenvolvimento nacional é tal qual construir uma sociedade livre, justa e solidária, realizar políticas públicas cuja reivindicação, pela sociedade, encontra fundamentação neste art.3. ${ }^{\circ}$, II. O papel que o Estado tem a desempenhar na perseguição da realização do desenvolvimento, na aliança que sela com o setor privado, é, de resto, primordial."

Nesse sentido, o papel do Estado em busca da garantia do desenvolvimento nacional, bem como a tentativa de consolidação da soberania nacional estão estampados no artigo 170. Nas palavras de José Afonso da Silva:

(...) quando o artigo 170 declara que a soberania nacional é um dos princípios da ordem econômica, isso terá de ter conseqüências específicas nesse campo. Tratar-se-á de soberania nacional econômica (...) a partir da Constituição de 1988, a ordem econômica brasileira, ainda de natureza periférica, terá de empreender a ruptura de sua dependência em relação aos centros capitalistas desenvolvidos. Essa é uma tarefa que a Constituinte, em última análise, confiou à burguesia nacional, na medida em que constitucionalizou uma ordem econômica de base capitalista. Vale dizer, o constituinte não rompeu com o sistema capitalista, mas quis que se formasse um capitalismo nacional autônomo, isto é, não dependente. ${ }^{340}$

Integrando-se de forma orgânica como artigo 170, estava o artigo $171^{341}$ da Constituição Federal de 1988, o qual vinculava a nacionalidade ao controle do capital social das companhias. Esse dispositivo constitucional, que tinha em seu bojo a intenção de preservar em mãos brasileiras o poder de decisão sobre o processo produtivo, foi extirpado

IX - tratamento favorecido para as empresas brasileiras de capital nacional de pequeno porte;

IX - tratamento favorecido para as empresas de pequeno porte constituídas sob as leis brasileiras e que tenham sua sede e administração no País.

Parágrafo único. É assegurado a todos o livre exercício de qualquer atividade econômica, independentemente de autorização de órgãos públicos, salvo nos casos previstos em lei.

${ }^{338} \mathrm{CF} / 88$ - Art. 3. ${ }^{\circ}$ Constituem objetivos fundamentais da República Federativa do Brasil:

I - construir uma sociedade livre, justa e solidária;

II - garantir o desenvolvimento nacional;

III - erradicar a pobreza e a marginalização e reduzir as desigualdades sociais e regionais;

IV - promover o bem de todos, sem preconceitos de origem, raça, sexo, cor, idade e quaisquer outras formas de discriminação.

${ }^{339}$ GRAU, Eros Roberto.op. cit., p. 217.

${ }^{340}$ SILVA, José Afonso da. op. cit., p. 770.

${ }^{341}$ Ver a íntegra do artigo na nota de rodapé 266. 
da Carta Magna, provavelmente por representar um entrave ao processo de privatização das estatais.

Pelo mesmo motivo, foi alterada a redação original do artigo $192^{342}$ da Constituição, cuja eficácia de seus incisos estava condicionada à edição de Lei Complementar, conforme já asseverado. Basta analisar-se com cuidado o disposto no seu antigo inciso III do artigo 192, o qual subordina a participação do capital estrangeiro aos interesses nacionais.

Com efeito, na redação atual do artigo 192 foram extirpados todos os incisos que continham as matérias que, desde 1988, aguardavam a regulamentação adequada.

Entretanto, a disciplina constitucional da política monetária do Brasil permanece essencialmente explícita no que sobrou do artigo 192 o qual fixa os princípios valorativos axiológicos que devem ser aplicados ao sistema:

\footnotetext{
${ }^{342}$ Versão original do artigo 192 cuja redação foi alterada pela EC n. ${ }^{\circ}$ 40/2003:

Art. 192 O sistema financeiro nacional, estruturado de forma a promover o desenvolvimento equilibrado do País e a servir aos interesses da coletividade, será regulado em lei complementar, que disporá, inclusive, sobre:

I - a autorização para o funcionamento das instituições financeiras, assegurado às instituições bancárias oficiais e privadas o acesso a todos os instrumentos do mercado financeiro bancário, sendo vedada a essas instituições a participação em atividades não previstas na autorização de que trata este inciso;

II - autorização e funcionamento dos estabelecimentos de seguro, previdência e capitalização, bem como do órgão oficial fiscalizador e do órgão oficial ressegurador;

II - autorização e funcionamento dos estabelecimentos de seguro, resseguro, previdência e capitalização, bem como do órgão oficial fiscalizador.

III - as condições para a participação do capital estrangeiro nas instituições a que se referem os incisos anteriores, tendo em vista, especialmente:

a) os interesses nacionais;

b) os acordos internacionais;

IV - a organização, o funcionamento e as atribuições do banco central e demais instituições financeiras públicas e privadas;

V - os requisitos para a designação de membros da diretoria do banco central e demais instituições financeiras, bem como seus impedimentos após o exercício do cargo;

VI - a criação de fundo ou seguro, com o objetivo de proteger a economia popular, garantindo créditos, aplicações e depósitos até determinado valor, vedada a participação de recursos da União;

VII - os critérios restritivos da transferência de poupança de regiões com renda inferior à média nacional para outras de maior desenvolvimento;

VIII - o funcionamento das cooperativas de crédito e os requisitos para que possam ter condições de operacionalidade e estruturação próprias das instituições financeiras.

$\S 1^{\circ}$ - A autorização a que se referem os incisos I e II será inegociável e intransferível, permitida a transmissão do controle da pessoa jurídica titular, e concedida sem ônus, na forma da lei do sistema financeiro nacional, a pessoa jurídica cujos diretores tenham capacidade técnica e reputação ilibada, e que comprove capacidade econômica compatível com o empreendimento.

$\S 2^{\circ}$ - Os recursos financeiros relativos a programas e projetos de caráter regional, de responsabilidade da União, serão depositados em suas instituições regionais de crédito e por elas aplicados.

$\S 3^{\circ}$ - As taxas de juros reais, nelas incluídas comissões e quaisquer outras remunerações direta ou indiretamente referidas à concessão de crédito, não poderão ser superiores a doze por cento ao ano; a cobrança acima deste limite será conceituada como crime de usura, punido, em todas as suas modalidades, nos termos que a lei determinar.
} 
Art. 192. O sistema financeiro nacional, estruturado de forma a promover o desenvolvimento equilibrado do País e a servir aos interesses da coletividade, em todas as partes que o compõem, abrangendo as cooperativas de crédito, será regulado por leis complementares que disporão, inclusive, sobre a participação do capital estrangeiro nas instituições que o integram.

Referido dispositivo postula como meta da política monetária não a inflação, mas o desenvolvimento equilibrado do país e o atendimento aos interesses gerais da coletividade.

Ainda que tenha havido alteração de sua redação para exclusão de seus incisos, certamente se pode afirmar que esse dispositivo permanece como a chave-mestra de toda a estrutura lógico-formal criada pela Constituição Federal para comportar os objetivos a serem perseguidos pela política monetária desenvolvida no Brasil.

Todavia, a lógica formal distribuída numa série de normativos esparsos (e retalhados) somente encontra finalidade se for preenchida pela realidade objetiva. Conforme Schuartz esclarece:

A prescrição de 'promover o desenvolvimento equilibrado do país' deve
ser entendida, no contexto do Sistema Financeiro Nacional, como uma
obrigação de adequar os meios de pagamento e de crédito disponíveis no
setor financeiro às necessidades do setor produtivo da economia
nacional. ${ }^{343}$

Ora, jamais será possível encontrar na constituição o princípio da "estabilidade monetária", pois esta deve ser uma circunstância da administração, um dever, um meio para a consecução de determinado fim e não um plano, um objetivo de governo. Nos dizeres de Camargo Vidigal:

A estabilidade, é bem de ver, não pode nem deve ser um fim último, um fim em si mesmo. Deve, pelo contrário, constituir-se em meio para que se alcancem os níveis de atividade que assegurem o pleno emprego dos fatores produtivos, mantido o ritmo ideal de desenvolvimento econômico ${ }^{344}$.

Assim, constata-se que o Banco Central deve agir para utilizar adequadamente os mecanismos de controle e execução de política monetária e creditícia à sua disposição e esses atos devem ser coordenados com os objetivos do governo, em consonância com as

\footnotetext{
${ }^{343}$ SCHUARTZ, Luiz Fernando. Banco Central: questões jurídico-políticas na Constituição de 1988. Revista de Direito Mercantil Industrial, Econômico e Financeiro, São Paulo, v. 93, p. 40, 1994.

${ }^{344}$ VIDIGAL, Geraldo de Camargo. op. cit., p. 66.
} 
outras políticas públicas implantadas no país para se buscar-se os resultados estampados nos dispositivos constitucionais comentados.

Vale, neste ponto, retomar o ensinamento de Avelãs Nunes ${ }^{345}$ quando ele menciona a necessidade da presença do Estado na tomada de decisões sobre política monetária, pois o significado dessa política não deve estar reduzido à busca da estabilidade de números e alcance de metas financeiras. Seu substrato constitucional é mais profundo: determina a busca contínua do desenvolvimento equilibrado do país, a serviço da coletividade ${ }^{346}$.

(...) Os direitos econômicos constituirão pressupostos da existência dos direitos sociais, pois, sem uma política econômica orientada para a intervenção e participação estatal na economia, não se comporão as premissas necessárias ao surgimento de um regime democrático de conteúdo tutelar dos fracos e mais numerosos.

Contudo o que se verifica, com base na atual realidade brasileira, até hoje severamente subordinada à influência das determinações do Consenso de Washington, é um claro desajuste na estrutura produtiva do país em busca de uma igualdade matemática pautada pelo atendimento das "metas inflacionárias", embora as normas formalmente constituídas nesse Estado de Direito determinem algo bem diferente disso.

\footnotetext{
${ }^{345}$ NUNES, António José Avelãs. Nota sobre a independência dos Bancos Centrais, cit.

${ }^{346}$ SILVA, José Afonso da. op. cit., p. 289.
} 


\section{CONCLUSÃO}

De acordo com os estudos empreendidos para este trabalho, chegou-se à conclusão de que a atuação do Estado como promotor "ordem econômica" é fundamental e imprescindível. É dever do Estado ser o formulador de políticas que visem ao desenvolvimento de acordo com os interesses da sociedade. Nesse sentido, qualquer ameaça à sua soberania e ao poder de regulamentar seus mercados deve ser rechaçada.

O Banco Central, por sua vez, ao conquistar no século XX a posição de executor da política monetária e creditícia deve estar em consonância com os objetivos do Estado proporcionando condições adequadas de desenvolvimento para a sociedade, pois somente assim será capaz de executar a verdadeira política monetária.

No caso específico tratado pelo capítulo III, verificou-se que o Banco Central do Brasil deve agir no sentido de utilizar adequadamente os mecanismos de controle e execução de política monetária e creditícia que estão à sua disposição. Todavia, estes atos devem ser coordenados com os objetivos do governo e em consonância com as outras políticas públicas implantadas no país de modo a buscar os resultados estampados nos dispositivos constitucionais comentados.

Não basta, assim, que existam, no sistema jurídico brasileiro, os parâmetros essenciais para se viabilizar o exercício de uma política monetária, pelo Estado, que seja congruente com os interesses sociais. É preciso, além disso, que haja vontade política para implementá-los.

Logo, o Estado deve intervir na economia de forma mais expressiva para priorizar questões centrais a fim de garantir não só empregos, mas também desenvolvimento social e melhor distribuição de renda e riqueza. A política monetária especialmente quando voltada aos interesses nacionais da coletividade, ao ser bem formulada e executada, seguramente pode contribuir par a consecução de tais objetivos. 


\section{REFERÊNCIAS BIBLIOGRÁFICAS}

ALMEIDA, José Roberto Novaes de. Economia monetária. São Paulo: Atlas, 2009.

ANDREZO, Andréa Fernandes; LIMA, Iran Siqueira. Mercado financeiro: aspectos históricos e conceituais. São Paulo: Thomsom Learning, 2002.

ARISTÓTELES. A política. Trad. Nestor Silveira Chaves, 15. ed. São Paulo: Ed. Escala, 1995.

BANCO CENTRAL DE LA REPÚBLICA ARGENTINA. Disponível em: <www.bcra.gov.br>. Acesso em: 05 nov. 2009.

BANCO CENTRAL DE VENEZUELA. Disponível em: <www.bcv.org.ve>.

- Reglamento Interno del Banco Central de Venezuela. Disponível em: <http://www.bcv.org.ve/c3/reglabcv.asp>. Acesso em: 17 out. 2009.

BANCO CENTRAL DO BRASIL. Disponível em: <www.bancocentral.gov.br>.

. Composição da DLSP. Disponível em: <http://www.bcb.gov.br/?COMPDLSP>. Acesso em: 26 dez. 2009.

. Definição e histórico. Disponível em: <http://www.bcb.gov.br/?COPOMHIST>. Acesso em: 20 nov. 2009.

- Sistema de Metas para a Inflação. Disponível em: <http://www.bcb.gov.br/?SISMETAS>. Acesso em: 20 nov. 2009.

BANCO CENTRAL. CHILE. Disponível em: <www.bcentral.cl>. Acesso em: 18 out. 2009.

BANCO CENTRAL EUROPEU. Disponível em: <www.ecb.europa.eu>.

BATISTA JR., Paulo Nogueira. Keynes e a estabilização do marco alemão In: LIMA, Gilberto Tadeu; SICSÚ, João; DE PAULA, Luiz Fernando (Coords.). Macroeconomia moderna: Keynes e a economia contemporânea. Rio de Janeiro: Campus, 1999. p. 340391.

BCE. Disponível em: <www.ecb.europa.eu>. 
BELLUZZO, Luiz Gonzaga de Mello. Dinheiro e as transfigurações da riqueza. In: FIORI, Maria Conceição Tavares; José Luiz (Org.). Poder e dinheiro: uma economia política da globalização. São Paulo: Vozes, 1997. v. 1, p. 151-193.

. Ensaios sobre o capitalismo no século XX. São Paulo: Unesp, 2004.

; ALMEIDA, Júlio Gomes de. Depois da queda: a economia brasileira da crise da dívida aos impasses do Real. Rio de Janeiro: Civilização Brasileira, 2002.

; CARNEIRO, Ricardo. Bloqueios ao crescimento. Política Econômica em Foco, n. 3, p. 1, jan./abr. 2004.

; TAVARES, Maria da Conceição. O país flutuante. Folha de S. Paulo, São Paulo, 21 mar. 2004. Caderno Mais!

BERCOVICI, Gilberto. O ainda indispensável direito econômico. In: BENEVIDES, Maria Victoria de Mesquita; BERCOVICI, Gilberto; MELO, Claudineu. (Orgs.) Direitos humanos, democracia e República: homenagem a Fábio Konder Comparato. São Paulo: Quartier Latin, 2009. p. 504-519.

. Concepção material de serviço público e Estado brasileiro. In: Serviços públicos e direito tributário. São Paulo: Quartier Latin, 2005.

Constituição econômica e desenvolvimento: uma leitura a partir da Constituição de 1988. São Paulo: Malheiros, 2005.

; MASSONETTO, Luís Fernando. A Constituição dirigente invertida: a blindagem da Constituição financeira e a agonia da Constituição econômica. Revista Trimestral de Direito Público, São Paulo, v. 45, p. 79-89, 2007.

; ___ ANDRADE, José Maria. Reforma do Estado, prestação de serviços públicos, contribuições especiais e federalismo. Revista do Instituto de Pesquisas e Estudos, Bauru, v. 40, n. 45, p. 171-193, jan./jun. 2006.

BLACKBURN, Simon. The Oxford dictionary of philosophy. England: Oxford University Press, 1994.

BLINDER, Alan S. Bancos centrais: teoria e prática. Trad. Maria Abramo Caldeira Brant. São Paulo: Ed. 34, 2000.

BNDES. Disponível em: <www.bndes.gov.br>. Acesso em: 15 nov. 2009. 
BOARD of Governors of the Federal Reserve System Washington, D.C. The Federal Reserve System - Purposes and Functions, 9. Disponível em: <http://www.federalreserve.gov/pf/pdf/pf_complete.pdf>. Acesso em: 04 abr. 2009.

BONAVIDES, Paulo. Teoria do Estado. 7. ed. São Paulo: Malheiros, 2009.

BRAGA, José Carlos de Souza. Os orçamentos estatais e a política econômica. In: BELLUZZO, Luiz Gonzaga de Mello; COUTINHO, Renata. Desenvolvimento capitalista no Brasil: ensaios sobre a crise. 3. ed. São Paulo: Brasiliense, 1984.

BULHÕES, Octavio Gouvêa. Depoimento. Brasília: Divisão de Impressão e Publicações do Departamento de Recursos Materiais do Banco Central do Brasil, 1990.

CAN YOU Bank on Italy? Times. Disponível em: $<$ http://www.time.com/time/magazine/article/0,9171,1115663,00.html>. Acesso em: 18 out. 2009).

CANO, Wilson. Venezuela: limites para uma nova política econômica. Economia $e$ Sociedade, Campinas, v. 11, n. 1, p. 95-127, jan./jun. 2002.

CARVALHO, Fernando J. Cardim. A independência do Banco Central e a disciplina monetária: observações céticas. Revista de Economia Política, v. 15, n. 4, out./dez. 2005.

CARVALHO, Fernando J. Cardim et al. Economia monetária e financeira: teoria e política. São Paulo: Campus, 2000.

CARVAlHO, Murilo de. Pontos e bordados: escritos de história e política. Belo Horizonte: UFMG, 1999.

CLARÍN. Disponível em: <http://www.clarin.com/diario/2009/10/07/um/m02014146.htm>. Acesso em: 17 out. 2009.

COMPARATO, Fábio Konder. Cláusulas contratuais de indexação de preços. Revista de Direito Mercantil, Industrial, Econômico e Financeiro, São Paulo, v. 85, 1992.

Ensaios e pareceres de direito empresarial. Rio de Janeiro: Forense, 1978.

. O indispensável direito econômico. In: . Ensaios e pareceres de direito empresarial. Rio de Janeiro: Forense, 1978.

- Na proto-historia das empresas multinacionais - o Banco Médici de Florença. Revista de Direito Mercantil, Industrial, Econômico e Financeiro, São Paulo, v. 54, p. 105-111, 1984. 
CORDER, Kevin J. Central Bank Autonomy: the Federal Reserve System in American Politics. New York: Garland Publishing Inc., 1998.

CORTEZ, Tiago Machado. Moeda, Estado e direito: o papel do Estado na ordem monetária e seu controle. 2004. Tese (Doutorado) - Faculdade de Direito, Universidade de São Paulo, USP, São Paulo, 2004.

O CUSTO dos juros altos. Folha de S. Paulo, São Paulo, 23 jan. 2004. Seção Opinião Econômica.

DAHRENDORF, Ralf. Sociedade e liberdade: para uma análise sociológica do presente. Trad. de Vamireh Chacon. Brasília: Ed. da UnB, 1982. (Coleção Pensamento Político 16).

DE CHIARA, José Tadeu. Capitais estrangeiros. Revista de Direito Mercantil, Industrial, Econômico e Financeiro, São Paulo, v. 16, n. 26, p. 67-84, 1977.

Disciplina jurídica das instituições financeiras. Revista de Direito Público, São Paulo, v. 41/42, p. 289-307, 1977.

. Moeda e ordem jurídica. Tese (Doutorado) - Faculdade de Direito, Universidade de São Paulo, USP, São Paulo, 1986.

DI PIETRO, Maria Sylvia Zanella. Direito administrativo. 14 ed. São Paulo: Atlas, 2002.

EICHENGREEN, Barry. A globalização do capital: uma história do Sistema Monetário Internacional. Tradução de Sergio Blum. São Paulo: Ed. 34, 2000.

FAORO, Raymundo. Os donos do poder: formação do patronato político brasileiro. 5. ed. Porto Alegre: Globo, 1979.v. 1 e 2.

FARIA, José Eduardo Campos de Oliveira. O direito na economia globalizada. São Paulo: Malheiros Ed., 2007.

(Org.). Regulação, direito e democracia. São Paulo: Fundação Perseu Abramo, 2002.

FIORI, José Luís. Globalização, hegemonia e império. In: TAVARES, Maria Conceição; FIORI, José Luís Fiori (Org.). Poder e dinheiro: uma economia política da globalização. São Paulo: Vozes, 1997. v. 1.

FORD, A. G. La Argentina y la crisis de Baring de 1890. In: ZAPIOLA, M. G. El regime oligárquico. Materiales para el estúdio de la realidade argentina (hasta 1930). Buenos Aires: Amorrortu Editores, 1975. 
FREITAS, Maria Cristina Penido de. Banco Central independente e coordenação das políticas macroeconômicas: lições para o Brasil. Economia e Sociedade, Campinas, v. 15, n. 2, p. 269-293, ago. 2006.

FRIEDMAN, Milton. Capitalismo e liberdade. Tradução de Luciana Carli. São Paulo: Artenova, 1977.

O poder e o dinheiro: episódios da história monetária. Tradução de Maria da Graça Pinhão. Portugal: Publicações Europa América, 1992.

FURTADO, Celso. Formação econômica do Brasil. 31. ed. São Paulo: Companhia Ed. Nacional, 2003.

Transformação e crise na economia mundial. São Paulo: Paz e Terra, 2006.

GAROFALO FILHO, Emílio. Dicionário de comércio exterior e câmbio. São Paulo: Saraiva, 2004.

GOODHART, Charles. The evolution of Central Banks. Massachusetts: MIT Press, 1988.

GOUVÊA, Gilda Portugal. Burocracia e elites burocráticas no Brasil. São Paulo: Paulicéia, 1994.

GRAU, Eros Roberto. A Ordem Econômica na Constituição de 1988. São Paulo: Malheiros, 2001.

- Preço, moeda, ordem pública e direito adquirido. In: Licitação e contrato administrativo: estudos sobre a interpretação da lei. São Paulo: Malheiros, 1995.

GUDIN, Eugênio. Princípios de economia monetária. 9. ed., Rio de Janeiro: Agir, 1954. v. 1 e 2 .

HAYEK, Friedrich A. O caminho da servidão. Tradução de Ana Maria Capovilla, José Augusto Stelle e Liane de Moraes Ribeiro. 5. ed. Rio de Janeiro: Instituto Liberal, 1990.

A desestatização do dinheiro: uma análise da teoria e prática das medidas simultâneas. Tradução de Heloisa Gonçalves Barbosa, Rio de Janeiro: Instituto Liberal, 1986.

HOLANDA, Sérgio Buarque de. Raízes do Brasil. 10.ed. Rio de Janeiro: J. Olympio, 1976.

HUBERMAN, Leo. História da riqueza do homem. Tradução de Waltensir Dutra. 21. ed. Rio de Janeiro: LTC, 1986. 
HUGON, Paul. Economistas célebres. Textos selecionados e apresentados pelo autor. São Paulo: Atlas, 1955.

A moeda: introdução à análise e às políticas monetárias e à moeda no Brasil. Tradução de Diva Benevides Pinho. 21.ed. São Paulo: Pioneira, 1973.

HUNT, E. K.; SHERMAN, Howard J. História do pensamento econômico. Tradução de Jaime Larry Benchimol. 2. ed. Rio de Janeiro: Vozes, 1978.

IBPT - INSTITUTO BRASILEIRO DO PLANEJAMENTO TRIBUTÁRIO. Disponível em: <www.ibpt.com.br>).

JAGUARIBE, Hélio. Condições institucionais do desenvolvimento. Rio de Janeiro: Instituto Superior de Estudos Brasileiros, 1958.

JALORETTO, Cláudio. Senhoriagem e financiamento do setor público. 2005. Dissertação (Mestrado) - Universidade de Brasília, UNB, Brasília, 2005.

JAVIER, Vadell. La Argentina de Kirchner: el retorno del Estado en el siglo XXI y sus implicaciones en la política externa.Observatorio Político Sul-Americano. Instituto Universitário de Pesquisas do Rio de Janeiro IUPERJ/UCAM. Disponível em: $<$ www.observatorio.iuperj.br>.

KEYNES, John Maynard. A teoria geral do emprego, do juro e da moeda. Tradução de Mário R. da Cruz. 2. ed. São Paulo: Nova Cultural, 1985. (Série Os Economistas).

KNIGHT, Frank. Risco, incerteza e lucro. Tradução de Hunfredo Cantuária. Rio de Janeiro: Expressão e Cultura, 1972.

KOCH, Arwed. El credito en el derecho. Tradução de Jose Ma Navas. Madrid: Revista de Derecho Privado, 1946.

KUNTZ, Rolf. Estado, mercado e direitos. In: AMARAL JR., Alberto do; PERRONEMOISÉS, Cláudia (Orgs.). O Cinqüentenário da Declaração Universal Dos Direitos Do Homem. São Paulo: Edusp, 1999.

LACERDA, Antônio Correa de; BOCCHI, João Ildebrando; REGO, José Marcio; BORGES, Maria Angélica; MARQUES, Rosa Maria. Economia brasileira. 3.ed. São Paulo: Saraiva, 2008.

LAFER, Celso. O Convênio do Café de 1976. São Paulo: Perspectiva, 1979. 
LASTRA, Rosa María. Central banking and banking regulation. Tradução de Dan Makus Kraft. Belo Horizonte: Del Rey, 2000.

LAUBADERE, André de. Droit publique economique. Paris: Dalloz, 1974.

LESTAPIS, Pierre de. La notion juridique de cédit. Paris: Librairie Générale de Droit \& de Jurisprudence, 1941.

LIBCHABER, Rémy. Recherches sur la monnaie en droit privé. Paris: Librairie Générale de Droit et de Jurisprudence, 1992.

MARTINS-COSTA, Judith. A boa-fé no direito privado (sistema e tópica no processo obrigacional). São Paulo: Ed. Revista dos Tribunais, 1999.

MASSONETTO, Luís Fernando. O direito financeiro no capitalismo contemporâneo: a emergência de um novo padrão normativo. 2006. Tese (Doutorado) - Faculdade de Direito da Universidade, São Paulo, USP, São Paulo, 2006.

MATTOS, Paulo Todescan Lessa (Coord.). Regulação econômica e democracia. São Paulo: Ed. 34, 2004.

MELlO, Celso Antônio Bandeira de. Curso de direito administrativo. 16. ed. São Paulo: Malheiros, 2002.

MORRIS, Charles R. O crash de 2008. Trad. Otacílio Nunes. São Paulo: Aracati, 2009.

MOSQUERA, Roberto Quiroga. Direito monetário e tributação da moeda. São Paulo: Dialética, 2006.

NOVELLI, José Marcos Nayme. Instituições, políticas e idéias econômicas: o caso do Banco Central do Brasil (1965-1998). São Paulo: Annablume; Fapesp, 2001.

NOVOA GALAN, Raul; NOVOA MUNHOZ, Gabriela. Derecho del mercado de capitales. Santiago: Editorial Jurídica de Chile, 1995.

NSOULI, Marwan M. Recherches sur les critères d'une Banque Centrale moderne: étude comparative entre la Banque du Liban, la Banque de France et la Banque Centrale Européene. Paris: Librairie Générale de Droit et de Jurisprudence, 2003.

NUNES, António José Avelãs. Neoliberalismo e direitos humanos. Rio de Janeiro: Renovar, 2003.

. Nota sobre a independência dos Bancos Centrais. Revista de Direito Mercantil Industrial, Econômico e Financeiro, São Paulo, v. 103, 1996. 
NUSDEO, Fábio. Curso de economia. São Paulo: Ed. Revista dos Tribunais, 1997.

NYU. Index of Documents from the Center for the Study of Central Banks Collection. Disponível em: <http://www1.law.nyu.edu/centralbankscenter/texts/order.html>. Acesso em: 18 out. 2009.

OBSERVATÓRIO Político Sul-Americano - Instituto Universitário de Pesquisas do Rio de Janeiro IUPERJ/UCAM. Disponível em: <www.observatorio.iuperj.br>.

OFFE, Claus. Problemas estruturais do Estado capitalista. Tradução de Barbara Freitag. Rio de Janeiro: Tempo Brasileiro, 1984.

OLIVEIRA, Gesner. Defesa da concorrência e regulação no setor bancário. In: CAMPILONGO, Celso Fernandes; ROCHA, Jean Cabral Veiga da; MATTOS, Paulo Todescan Lessa (Coords.). Concorrência e regulação no sistema financeiro. São Paulo: Max Limonad, 2002.

OLIVEIRA, Giuliano; MAIA, Geraldo; MARIANO Jefferson. O sistema de Bretton Woods e a dinâmica do sistema monetário internacional contemporâneo. Pesquisa \& Debate, São Paulo, v. 19, n. 2, p. 195-219, 2008.

OREIRO, José Luís; PAULA, Fernando de; SOBREIRA, Rogério (Org.). Política monetária, bancos centrais e metas de inflação. São Paulo: FGV, 2009.

PALMITER, Alan R. Securities regulation: examples \& explanations. New York: Aspen Law \& Business, 1998.

PEREIRA, Luis Carlos Bresser; FERRER, Aldo. Dolarização crônica: Argentina e Brasil. Revista de Economia Política, São Paulo, v. 11, n. 1, jan./mar. 1991.

POLANYI, Karl. A grande transformação: as origens de nossa época. Tradução de Fanny Wrobel. Rio de Janeiro: Campus, 2000.

PRADO, Maria Clara do. A real história do real: uma radiografia da moeda que mudou o Brasil. Rio de Janeiro: Record, 2006.

PRATES, Daniela Magalhães; CINTRA, Marcos Antônio Macedo. Keynes e a hierarquia de moedas: possíveis lições Para o Brasil. Campinas: Instituto de Economia, Unicamp, 2007. n. 137.

RATNER, David L. Securities regulation in a Nutshell. 5th ed. Saint Paul: West Publishing Co., 1996. 
REPPUBLICA.IT

em:

<http://www.repubblica.it/2005/h/sezioni/economia/banche10/banche10/banche10.html?re $\mathrm{f}=$ search $>$. Acesso em: 18 out. 2009.

RESERVE BANK OF AUTRALIA. Disponível em: $<$ http://www.rba.gov.au/PublicationsAndResearch/Bulletin/2009/index.html>. Acesso em: 03 abr. 2009.

RIST, Charles. Historia de las doctrinas relativas al crédito y a la moneda: desde Jonh Law hasta La actualidad. Tradução de Ernesto Schop Santos. Barcelona: Bosch Casa Editorial, 1945.

ROUBIER, Paul. Droits subjectifs et situations juridiques. Paris: Dalloz, 1963.

SALOMÃO NETO, Eduardo. Direito bancário. São Paulo: Atlas, 2005.

SANTORO, Maurício. O modelo chileno e os dilemas da América do Sul. Observatório Político Sul-Americano-Instituto Universitário de Pesquisas do Rio de Janeiro IUPERJ/UCAM. Disponível em: <www.observatorio.iuperj.br>.

SCHUARTZ, Luiz Fernando. Banco Central: questões jurídico-políticas na Constituição de 1988. Revista de Direito Mercantil Industrial, Econômico e Financeiro, São Paulo, v. 93, 1994.

SCHUMPETER, Joseph Alois. A teoria do desenvolvimento econômico. Tradução de Maria Silvia Possas. São Paulo: Abril Cultural, 1982.

SCHWARZ, Roberto. As idéias fora do lugar. In: Ao vencedor as batatas. São Paulo: Duas Cidades, 1992.

SEDILLOT, René. Onze monnaies plus deux - deux mille ans d'aventure. Paris: Hachette, 1972 .

SENADO FEDERAL. Disponível em: <www.senado.gov.br/agencia>. Acesso em: 18 out. 2009.

SICSÚ, João. Tese da independência do Banco Central e a estabilidade de preços: uma aplicação do Método Cukierman à História do FED. Estudos Econômicos, São Paulo, v. 6, n. 1, p. 21-49, jan./abr. 1996.

SILVA, José Afonso da. Curso de direito constitucional positivo. 19. ed. São Paulo: Malheiros, 2000. 
SMITH, Adam. A riqueza das nações: investigação sobre sua natureza e suas causas. Tradução de Luiz João Baraúna. São Paulo: Nova Cultural, 1996. v. 1 e 2.

SOBREIRA, Rogério (Org.). Regulação financeira e bancária. São Paulo: Atlas, 2005.

SOLA, Lourdes; KUGELMAS, Eduardo; GARMAN, Cristopher; MARQUES, Moisés. Banco Central, autoridade política e governabilidade democrática. SOLA, Lourdes; KUGELMAS, Eduardo; WHITEHEAD, Laurence. Banco Central: autoridade política e democratização: um equilíbrio delicado. Rio de Janeiro: FGV, 2002.

SOLOMON, Robert. O Sistema Monetário Internacional 1945-1976. Tradução de Nathanael C. Caixeiro. Rio de Janeiro: Zahar, 1979.

VENÂNCIO FILHO, Alberto. A intervenção do Estado no domínio econômico. Rio de Janeiro: Fundação Getulio Vargas, 1968.

VERÇOSA, Haroldo Malheiros Duclerc. Bancos centrais no direito comparado: o Sistema Financeiro Nacional e o Banco Central do Brasil. São Paulo: Malheiros, 2005.

O conceito de "reservas bancárias", e as características do mútuo e do depósito bancários. Revista de Direito Mercantil, Industrial, Econômico e Financeiro, São Paulo, v. $110,1998$.

VIDIGAL, Geraldo de Camargo. Disciplina dos órgãos de direção monetária. Tese (Livre Docência) - Faculdade de Direito, Universidade de São Paulo, São Paulo 1964. Teoria geral do direito econômico. São Paulo: Ed. Revista dos Tribunais, 1977.

VILLA, Rafael. A política externa Venezuelana de Chávez para a América do Sul: entre a ideologização das identidades e as necessidades do pragmatismo. Análise de Conjuntura, n. 10, Observatório Político Sul-Americano - Instituto Universitário de Pesquisas do Rio de Janeiro IUPERJ/UCAM, outubro/2007. Disponível em: <www.observatorio.iuperj.br>.

VIVANTE, Cesare. Tratatto de diritto commerciale: le obbligazioni (contrati e prescrizioni), 3.ed. Milano: Dott. Francesco Vallardi, 1906. t. 3.

WEBER, Max. Historia económica general. Tradução de Manuel Sánchez Sarto. 2.ed. Ciudad de Mexico: Fondo de Cultura Económica, 1956. Os pensadores. 3.ed. São Paulo: Abril, 1985.

WEINSTEIN, Martin. Summary of American Law. San Francisco: The Lawyers Cooperative Publishing Co., 1988. 
WESSEL, David. In fed we trust: ben bernake's war on the great panic, how the Federal Reserve Became the Fourth Branch of Government. New York: Crown Business, 2009.

WRAY, L. Randall. Trabalho e moeda hoje: a chave para o pleno emprego e a estabilidade dos preços. Tradução de José Carlos de Assis. Rio de Janeiro: Ed. UFRJ/Contraponto, 2003.

YAZBEK, Otavio. O risco de crédito e os novos instrumentos financeiros: uma análise funcional. In: WAISBERG, Ivo; FONTES, Marcos Rolim Fernandes (Coords.), Contratos bancários. São Paulo: Quartier Latin, 2006.

Regulação do mercado financeiro e de capitais. São Paulo: Campus, 2007. 